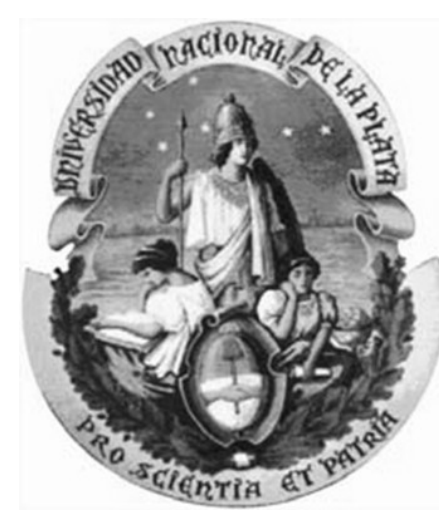

Universidad Nacional de La Plata

Facultad de Ciencias Jurídicas y Sociales

Maestría en Relaciones Internacionales

Tesis de maestría

POSTULADOS EMERGENTES DE LA JURISPRUDENCIA DE LA CORTE INTERAMERICANA DE DERECHOS HUMANOS EN RELACIÓN AL DERECHO INTERNACIONAL PÚBLICO

\title{
Fabián Salvioli
}


De Emir Omar Salvioli aprendí la militancia.

De Haydée Rosa Cordero aprendí el ejercicio cotidiano de la solidaridad.

De los dos construí mis valores, porque predicaron, y lo siguen haciendo, con el ejemplo.

Este libro es para mi madre y mi padre, o mejor: este libro es producto de ellos. 


\section{Algo más que una nota del Autor}

En nuestro país y en el continente americano, hay muchos teóricos que trabajan el Derecho Internacional de los Derechos Humanos y el Sistema Interamericano. Basta para darse cuenta de ello, observar la bibliografía que hemos citado en el libro. Esta publicación sólo pretende ser una modesta contribución a esa importante tarea, que otros, quienes han sido y serán mis maestras y maestros, ya han realizado con sobrada solvencia.

En tren de deslindar responsabilidades, quisiera señalar que los errores que existen en la presente publicación me corresponden enteramente; pero si esta obra tiene aciertos, ello se debe a algunas circunstancias, que paso a detallar.

La primera de ellas, es que durante muchos años he podido trabajar con absoluta libertad (y continúo haciéndolo), en la cátedra de Derecho Internacional Público y en el Instituto de Relaciones Internacionales de la Universidad Nacional de La Plata. Ambos ámbitos son dirigidos por quien fue mi director de tesis, y por ello, el agradecimiento al profesor Consani, quisiera ampliarlo a su justa dimensión.

La segunda es que tengo la suerte, tanto en el Departamento de Derechos Humanos del Instituto de Relaciones Internacionales, como en la Comisión 7 de la Cátedra II de Derecho Internacional Público, de estar rodeado de personas que, además de ser altamente competentes en lo académico institucional, son mucho mejor en la faz humana. Por eso, este párrafo para los "amigos abrigos" (como dice Eduardo Galeano).

Un tercer agradecimiento a los pasillos, las paredes y los fantasmas del Colegio Nacional de La Plata.

El cuarto agradecimiento es a Amnistía Internacional, porque la militancia en dicha institución, me enseñó que es inconsecuente trabajar en derechos humanos sin practicarlos; sin esforzarse por llevar adelante la tolerancia y la no discriminación; y ello me ayudó a crecer como persona.

Un quinto agradecimiento, al profesor brasileño, y actual Vicepresidente de la Corte Interamericana de Derechos Humanos, Antonio Cançado Trindade, una verdadera eminencia en derecho internacional, reconocida en los círculos jurídicos y académicos más prestigiosos del mundo. El prólogo a mi modesto trabajo, revela su generosidad, me llena de orgullo y me emociona profundamente.

El último agradecimiento siempre es el más importante, y me permite englobar a aquellos no mencionados aún, como por ejemplo, las secretarias administrativas del Instituto de Relaciones Internacionales.

Hay un ámbito, que como lugar humano que es, tiene sus luces y sus sombras, y como todos nosotros, sus grandezas y sus miserias. En ese lugar, no me han preguntado ni cuánto dinero tenía, ni cuál era mi ideología; me dieron la libertad para elegir mis creencias, me brindaron todo, sin pedirme nada a cambio, y obtuve conocimientos y herramientas de trabajo que me posibilitaron llegar a dictar cursos o seminarios en muchos ámbitos académicos de Argentina, del resto de América Latina, y de Europa. A la Universidad Nacional de La Plata, mi eterna gratitud. 


\section{Prólogo}

La protección de los derechos humanos ha asumido una posición central en la agenda internacional de este final de siglo. Los sistemas regionales de protección encuéntranse hoy día en plena evolución, en el marco de la universalidad de los derechos humanos. En lo que concierne al sistema europeo de protección, cuando entre en vigor el Protocolo XI a la Convención Europea de Derechos Humanos, el próximo 01 de noviembre de 1998, se alterará profundamente el mecanismo de supervisión de la Convención, con la nueva Corte Europea de Derechos Humanos como su único órgano jurisdiccional, con acceso directo (jus standi) de los individuos para traer un caso concreto directamente ante ella. En lo que toca al sistema africano de protección, en septiembre de 1995 se concluyó la elaboración del Proyecto de Protocolo a la Carta Africana de Derechos Humanos y de los Pueblos sobre el Establecimiento de una Corte Africana de Derechos Humanos y de los Pueblos. Y, en nuestro continente, el sistema interamericano de protección es objeto de constante reflexión en los círculos jurídicos latinoamericanos teniendo presente la necesidad de su perfeccionamiento y fortalecimiento.

A pesar de todos los logros alcanzados a lo largo de las últimas décadas, nuestro sistema regional todavía padece de desequilibros - estructurales, normativos, procesales y jurisprudenciales - que cabe remediar y superar lo más pronto posible. El principal desequilibrio estructural resulta del hecho que no todos los Estados Partes en la Convención Americana sobre Derechos Humanos han aceptado la competencia obligatoria en materia contenciosa de la Corte Interamericana de Derechos Humanos, y no todos los Estados miembros de la Organización de los Estados Americanos han ratificado la Convención Americana. El principal desequilibrio normativo reside en la laguna histórica de nuestro sistema regional en cuanto a los derechos económicos, sociales y culturales, que será remediada el día en que entre en vigor el primer Protocolo Adicional a la Convención Americana sobre Derechos Humanos en Materia de Derechos Económicos, Sociales y Culturales (Protocolo de San Salvador de 1988). No se justifica que estos derechos no sean tratados como verdaderos derechos que son, a la luz de una concepción necesariamente integral de todos los derechos humanos.

Los procedimientos bajo la Convención Americana están permeados, en todas las etapas, de desequilibrios, - como vengo señalando en mis escritos en los últimos años. El más grave desequilibrio procesal incide en la injustificable falta de locus standi de los individuos ante la Corte Interamericana (exceptuada, bajo el actual Reglamento de La Corte, la etapa de reparaciones). A todo derecho corresponde necesariamente la capacidad procesal de vindicarlo, y es la presunta víctima la verdadera parte demandante ante la Corte. En fin, la jurisprudencia de la Corte - in statu nascendi - revela igualmente desequilibrios, con algunos derechos todavía aguardando interpretación; además, se ha desarrollado en la última década la obligación general del artículo 1(1), pero todavía no la del artículo 2 (deber general de adoptar disposiciones de derecho interno), de capital importancia para la evolución de nuestro sistema regional de protección. Urge promover una mayor comprensión de las obligaciones legislativas y judiciales de los Estados Partes en la Convención Americana, por cuanto esta última vincula no solamente a los Gobiernos, sino a los Estados (todos sus órganos y agentes).

Es imperativo, en nuestros días, impulsar un mejor entendimiento del amplio alcance de las obligaciones convencionales de protección, que abarcan todo y cualquier acto u omisión de los Estados Partes, de cualquiera de sus órganos o agentes, sea del Poder Ejecutivo, sea del Legislativo o del Judicial. Es este principio fundamental del derecho de la responsabilidad del Estado, el que debe orientarnos, sin que se justifique en nuestro sistema regional el recurso a fórmulas nebulosas, importadas indebidamente de la jurisprudencia bajo la Convención Europea de Derechos Humanos, como las del «margen de apreciación» o de la «cuarta instancia», desprovistas de sentido al margen 
del Estado de Derecho. Lo que más se necesita, en nuestro continente, es un profundo cambio de mentalidad, a partir de una mayor precisión conceptual.

Todos los estudios e iniciativas que vengan verdaderamente aclarar el universo conceptual propio del presente dominio de la protección son bienvenidos. El presente libro del Profesor Fabián Omar Salvioli constituye un valioso aporte en este propósito básico. Como señala el autor en la presentación de la obra, su aspiración se desdobla en tres objetivos, a saber: contribuir a la identificación de la evolución del Derecho Internacional de los Derechos Humanos a través de la jurisprudencia de la Corte Interamericana de Derechos Humanos, servir de ayuda a peticionarios ante un órgano de protección internacional de los derechos humanos, y favorecer, finalmente, la más amplia difusión de la temática.

A partir de las características de la protección internacional (sintetizadas por el autor en la internacionalización, la subsidiariedad, la irrenunciabilidad, y la progresividad), pasa la obra a identificar lo que denomina de «Postulados emergentes» de la Corte Interamericana de Derechos Humanos. La utilización de esta expresión atiende a la preocupación del autor (que se desprende sobre todo del capítulo V) de no limitarse solamente a enunciados que ya se cristalizaron en principios, sino también abarcar líneas de pensamiento en evolución, que todavía no alcanzaron tal nivel.

Este enfoque abre un vasto campo de investigación, abarcando inclusive los llamados "postulados de creación pretoriana» (capítulo VIII) que emergen de la jurisprudencia de la Corte Interamericana. Comprende, además, los planos tanto normativo (los derechos protegidos) como operativo (mecanismos de protección). De modo general, el autor agrupa los Postulados identificados en tres tipos, a saber, los tomados de contenidos propios del Derecho Internacional Público general, los que corresponden a contenidos propios del Derecho Internacional de los Derechos Humanos, y los que emergen de la creación pretoriana de la Corte Interamericana.

Entre los postulados identificados en los capítulos VI y VII, encuéntrase, con destaque, el de la interpretación pro victima (propio del Derecho Internacional de los Derechos Humanos, mediante el cual las presunciones operan a favor de las presuntas víctimas, con incidencia directa, v.g., en el requisito del previo agotamiento de los recursos de derecho interno), además del principio jura novit curia. También cabe destacar la especificidad de los tratados de derechos humanos (con sus múltiples implicaciones), el principio de la no - discriminación (de gran potencialidad, pero todavía no suficientemente desarrollado en la jurisprudencia de nuestro sistema regional de protección), y la libre valoración de las pruebas (por la Corte Interamericana).

El presente libro sobre los Postulados Emergentes de la Jurisprudencia de la Corte Interamericana de Derechos Humanos en Relación al Derecho Internacional Público deriva de la Tesis de Magister presentada por el autor en la Universidad de La Plata, aprobada con la máxima calificación, por un jurado presidido por el Profesor Emilio Mignone, distinguido defensor de los derechos humanos y Presidente del Centro de Estudios Legales y Sociales (CELS) con sede en Buenos Aires. Es para mí un privilegio prefaciarlo, tratándose de la obra de uno de los más promisorios talentos de la nueva generación de jusinternacionalistas de los países del Cono Sur.

A pesar de su juventud, Fabián Salvioli cuenta ya con más de sesenta publicaciones, en distintos países (Argentina, Brasil, Costa Rica, España, Portugal, Francia y Dinamarca), y conjuga la trayectoria académica con la experiencia práctica en el campo de los derechos humanos. En cuanto a la primera, el autor, Profesor de Derecho Internacional Público de la Universidad Nacional de La Plata (donde está también a cargo del Derecho Internacional de los Derechos Humanos), así como de la Universidad Nacional de Lomas de Zamora y de la Universidad Nacional de La Pampa, ha además dictado cursos - a partir de 1993 - en instituciones europeas, como la Scuola de Politica 
Internazionale de Roma, la Universidad Complutense de Madrid, la Universidad de Sevilla, entre otras.

En cuanto a la praxis, Fabián Salvioli fue presidente de la Sección Argentina de Amnesty International en dos ocasiones (1989 y 1994-1995), integró - en el período 1991-1996 - el equipo interdisciplinario de educación formal del Movimiento Ecuménico por los Derechos Humanos en Argentina, y es hoy Subdirector del Instituto de Derechos Humanos del Colegio de Abogados del Departamento Judicial de La Plata, entre otras actividades. Guardo siempre el grato recuerdo de las conversaciones que tuvimos en Estrasburgo, cuando, en 1993, fue mi alumno, y, poco después, en 1995 y 1996, cuando compartimos cátedra, en el Instituto Internacional de Derechos Humanos, fundado por René Cassin; desde el inicio me impresionaron su dedicación a la temática, sumada a su extraordinaria capacidad de trabajo.

Si tuviera que singularizar un punto de la materia tan bien tratada en la densa obra del Profesor Fabián Salvioli, mi escogencia no podría incidir en otro que la afirmación y gradual cristalización, en el marco del Derecho Internacional de los Derechos Humanos, tanto de la subjetividad jurídica internacional del individuo, como de su plena capacidad jurídica internacional. Como señalé en mi curso sobre la materia en la Academia de Derecho Internacional de La Haya hace una década (tomo 202 del Recueil des Cours), todo jusinternacionalista, fiel a los orígenes históricos de su disciplina (el droit des gens), sabrá contribuir al gran movimiento de dimensión universal orientado al rescate del ser humano como sujeto del Derecho Internacional de los Derechos Humanos dotado de plena capacidad jurídica internacional.

San José de Costa Rica.

\section{Antônio Augusto CANÇADO TRINDADE}

Ph.D. (Cambridge), Vicepresidente de la Corte Interamericana de Derechos Humanos, Profesor Titular de la Universidad de Brasilia, Miembro de los Consejos Directivos del Instituto Interamericano de Derechos Humanos (Costa Rica) y del Instituto Internacional de Derechos Humanos (Estrasburgo), Associé del Institut de Droit International 


\section{CAPITULO I}

\section{INTRODUCCION}

Con la realización de la presente publicación, nos hemos propuesto tres objetivos. El primero, es contribuir a la comprensión de los pasos evolutivos que ha dado el Derecho Internacional de los Derechos Humanos, tomando como base el trabajo realizado por la Corte Interamericana de Derechos Humanos, a través de sus decisiones.

Nuestro segundo propósito, apunta a colaborar teóricamente con aquellos que tienen la responsabilidad de llevar un asunto ante un órgano internacional de derechos humanos. Por ello, hemos prentendido la identificación de "Postulados", o líneas de pensamiento de la Corte Interamericana de Derechos Humanos.

Finalmente, queremos colaborar con la difusión de los derechos humanos. La tarea por el respeto y la vigencia de éstos, no estará completa si protección y promoción, no se encaran conjuntamente: protección para reparar las violaciones a los derechos humanos producidas, y promoción para la concientización y práctica de los derechos humanos en el seno de la sociedad.

Esta obra, vincula al Derecho Internacional Público y al Derecho Internacional de los Derechos Humanos, desde la perspectiva llevada adelante por la jurisprudencia de la Corte Interamericana de Derechos Humanos; uno de los tribunales más importantes de protección de los derechos y libertades fundamentales, con que cuenta el Derecho Internacional Contemporáneo 1.

La Corte Interamericana de Derechos Humanos, ha sido creada por la Convención Americana de Derechos Humanos, el llamado Pacto de San José de Costa Rica 2 , y fue instaurada en el año 1979, encontrándose su sede física, en dicha ciudad centroamericana.

Este máximo tribunal continental en materia de derechos humanos, resolvió la primera cuestión que le fue sometida, en una Opinión Consultiva que le fue solicitada por un Estado miembro de la Organización de los Estados Americanos), el 24 de setiembre de 19823.

Según considera Cançado Trindade, la puesta en marcha de la construcción jurisprudencial de la Corte Interamericana (1982) da comienzo a una nueva etapa en la historia del sistema interamericano de derechos humanos. El autor señala, como fase de consolidación del sistema, la entrada en vigor de la Convención Americana (1978); asimismo, detalla, como inicio del período de perfeccionamiento, la puesta en funcionamiento, y la primera opinión dada por la Corte Interamericana de Derechos humanos, a que hemos hecho mención 4.

El paso del tiempo le ha dado al trabajo de la Corte cierta habitualidad. Los inicios han sido lentos, y hasta el mes de junio de 1987, las decisiones del tribunal sólo habían sido en materia consultiva, competencia que hasta entonces sumaba seis dictámenes.

El 26 de junio de 1987, la Corte dictó sus dos primeras sentencias de excepciones preliminares, en sendos casos contenciosos contra la república de Honduras 5.

Ha sido un hito, en la historia del sistema interamericano, la primera sentencia pronunciada sobre el fondo, en el caso Velásquez Rodríguez, el 29 de julio de 19886 .

A partir de entonces, la competencia contenciosa avanzó despacio, hasta que, en la actualidad, parece haberse destrabado el envío de casos por parte de la Comisión Interamericana de Derechos Humanos, y la Corte posee, entre asuntos resueltos y en trámite, una interesante producción jurisprudencial, tanto en casos contenciosos 7, como en opiniones consultivas.

Sostenemos que la Corte Interamericana de Derechos Humanos, ha llevado adelante, en dicha jurisprudencia, ciertas líneas de pensamiento, las cuáles hemos pretendido analizar y clasificar, y de las que pueden extraerse axiomas propios del Derecho Internacional Público y del Derecho Internacional de los Derechos Humanos. 
Pero también, creemos que la Corte Interamericana de Derechos Humanos tiene construida una serie de Postulados, que han sido creados por su propia actividad, y que derivan de la necesidad de cumplir los fines para los cuales el Alto tribunal ha sido establecido.

El estudio y análisis de estos Postulados, que surgen de la jurisprudencia de la Corte Interamericana de Derechos Humanos, su clasificación conforme al Derecho Internacional Público tradicional, al Derecho Internacional de los Derechos Humanos, y su innovativa tarea pretoriana, forman el núcleo del presente libro. Para ello, hemos dividido el presente estudio en nueve capítulos, que tratan de abordar los campos que venimos describiendo.

El Capítulo II nos habla de la relación entre el Derecho Internacional Público y los derechos humanos. Se analiza en el mismo el surgimiento de la protección internacional como se entiende actualmente, luego de las terribles consecuencias de la Segunda Guerra Mundial.

Asimismo, se hace hincapié en las características de la protección internacional de los derechos humanos, dentro de las Organizaciones Internacionales, partiendo desde el punto de vista del Derecho Internacional Contemporáneo. Así, tomamos en cuenta: la internacionalización, la subsidiariedad, la irrenunciabilidad y la progresividad.

La subsidiariedad es retomada dentro del presente trabajo, al analizar la reglas del agotamiento de los recursos internos, desde la jurisprudencia emitida por la Corte Interamericana de Derechos Humanos 8 .

A partir del concepto de progresividad, puede comprenderse que la Corte Interamericana de Derechos Humanos haya establecido Postulados de creación propia, que ya forman parte, a nuestro juicio, del Derecho Internacional de los Derechos Humanos 9.

Luego, dentro del Capítulo II, entramos de lleno a las modificaciones que el Derecho Internacional clásico, ha sufrido como consecuencia de la evolución de la protección internacional de los derechos humanos.

En dicho punto, se tienen en cuenta las cuestiones atinentes a la soberanía estatal y a la protección de los derechos humanos 10; y un tema básico para una tutela eficaz de los derechos y libertades fundamentales: la subjetividad jurídico internacional del individuo, donde, conforme a la característica de progresividad, observamos una ampliación constante, tanto en su faz activa 11, como pasiva 12 .

Después, se ven las relaciones entre el Derecho Internacional convencional (o derecho de los tratados) y los derechos humanos, observándose las diferencias entre tratados y declaraciones, el objeto de las convenciones tradicionales y aquellas que protegen los derechos humanos, y cómo estos se sitúan en relación al orden público internacional (ius cogens).

La primera cuestión es retomada en el análisis posterior, cuando tratamos los llamados "mecanismos extraconvencionales" de protección, que existen en el seno de la Organización de las Naciones Unidas 13, y en la jurisprudencia seleccionada de la Corte Interamericana de Derechos Humanos, sobre aquellos Postulados, que señalamos como tomados del Derecho Internacional de los Derechos Humanos 14 .

El objeto de los tratados también es materia de estudio en otra parte del presente libro, cuando se diferencia la naturaleza jurídica de las convenciones típicas del Derecho Internacional Público, con aquella que corresponde a los pactos de derechos humanos $\mathbf{1 5}$.

El final del Capítulo II describe a los nuevos instrumentos de derechos humanos, propios de las relaciones internacionales contemporáneas: nos referimos a las declaraciones y programas de acción, que derivaron de las "megaconferencias" organizadas por las Naciones Unidas, desde el fin de la llamada "guerra fría".

El Capítulo III aborda las relaciones entre la protección internacional y regional de los derechos humanos. Allí, realizamos una comparación del estado jurídico general en la materia, en los diferentes ámbitos internacionales (Naciones Unidas, regiones donde existen instrumentos jurídicos, órganos y procedimientos; y la región Asia-Pacífico, que es, actualmente, la más atrasada en la materia). 
Después, se estudian los rasgos más importantes de cada uno de los diferentes sistemas regionales de derechos humanos, comenzando por la Liga de los Estados Arabes, y su principal instrumento: la Carta Arabe de Derechos Humanos 16 .

Luego, se realiza el mismo estudio dentro del Consejo de Europa, y del pionero Convenio Europeo para la Protección de los Derechos del Hombre y las Libertades Fundamentales de 195017 .

A continuación, se observa el desarrollo de la protección dentro de la Organización de la Unidad Africana, y los rasgos principales de la Carta Africana de Derechos Humanos y de los Pueblos, la llamada "Carta de Banjul", en 198118 .

También, se realiza un resumen del último tratado regional aprobado en el mundo: la Convención sobre Derechos y Libertades Fundamentales del Hombre de la Comunidad de los Estados Independientes 19.

La vista del panorama institucional internacional, sobre convenios troncales de derechos humanos, nos ha servido para poder analizar, tanto las características similares, como las diferencias que existen con la Convención Americana sobre Derechos Humanos, el instrumento medular del sistema interamericano, y el más importante para el trabajo de los Capítulos V, VI y VII del presente libro $\mathbf{2 0}$.

La tercera parte del Capítulo III, lleva adelante el ingreso a los mecanismos de protección, que existen en todos los sistemas mencionados ut supra.

Para ello hemos tomado la clasificación que distingue entre "protección convencional", con sus mecanismos no contenciosos, cuasicontenciosos y contenciosos; y "protección extraconvencional"; esta división ha sido realizada por Villán Durán, en su curso de Derecho Internacional de los Derechos Humanos 21.

Luego, se arriba a los órganos encargados de la protección de los derechos humanos; comenzando el estudio por aquellos que son de tipo administrativo, y finalizando por los órganos de tipo jurisdiccional, lo cual da cabida para comenzar el análisis de la Corte Interamericana de Derechos Humanos, y las tareas que ella leva a cabo.

El Capítulo IV llega, en efecto, a la composición y competencias de la Corte Interamericana de Derechos Humanos; se explica la competencia consultiva, y las diferencias que existen en dicha materia, comparada con la Corte Internacional de Justicia y con el Tribunal Europeo de Derechos Humanos. A continuación, se destacan los principales aspectos de la competencia contenciosa, y, finalmente, la potestad que tiene el Tribunal de dictar medidas provisionales.

A continuación, se expone una síntesis de los hechos y las normas que la Corte Interamericana de Derechos Humanos ha aplicado en cada una de las opiniones consultivas, y de los casos contenciosos, tanto de los resueltos, como de aquellos que se encuentran en trámite. Las decisiones de la Corte Interamericana motivadas por las consultas y los casos contenciosos, son la base más importante, para el análisis del material, que hemos utilizado para la confección de los capítulos VI, VII y VIII.

Finalmente, se mencionan las medidas provisionales dictadas por la Corte Interamericana, las cuales no son desarrolladas, porque no han sido abordadas para la presente investigación.

El Capítulo V pretende delimitar el estudio y los términos que se van a utilizar en los capítulos siguientes: así, explicamos porqué se ha descartado el término «principio», y se habla de «Postulados» Emergentes de la jurisprudencia de la Corte Interamericana de Derechos Humanos.

En la primera parte del Capítulo V, se mencionan las dificultades que el término «principio» ha acarreado, tanto al derecho interno, como al Derecho Internacional. En cuanto a los «Principios Generales del Derecho», son considerados como fuentes del Derecho Internacional Público, conforme lo define el Estatuto de la Corte Internacional de Justicia 22.

También destacamos a qué se considera, en el desarrollo actual del Derecho Internacional Contemporáneo, un «Principio del Derecho Internacional» 23.

Luego, se toma en cuenta que los Postulados Emergentes de la jurisprudencia de la Corte Interamericana de Derechos Humanos, que han sido catalogados como propios del Derecho Internacional Público, forman parte de éste último por ser reglas convencionales, principios del 
Derecho Internacional, resoluciones de órganos internacionales, o bien por ser normas aplicadas por la Corte Permanente de Justicia Internacional, o la Corte Internacional de Justicia.

El Capítulo V, continúa con la descripción de la segunda categoría de Postulados, aquellos que se consideran propios del Derecho Internacional de los Derechos Humanos, con la salvedad, de que algunos de ellos se toman del Derecho Internacional Público, pero su objeto principal es la protección de los derechos humanos (piénsese por ejemplo en el principio de la libre determinación de los pueblos), o han sido creación directa de la disciplina (como el principio «pro homine").

También, el Capítulo $\mathrm{V}$ se refiere a los Postulados que emergen directamente de la jurisprudencia de la Corte Interamericana de Derechos Humanos, cuyo análisis in extenso, se encuentra en el Capítulo VIII del presente libro.

Finalmente, se asevera que la definición de Postulado para la investigación desarrollada, es un enunciado expreso o implícito, que surge de las decisiones tomadas por dicho Tribunal, y de acuerdo a ciertos requisitos.

Dichos requisitos son la reiteración de párrafos en varias decisiones, que refuerzan un concepto que la Corte Interamericana, sin duda, ha querido jerarquizar; o, aunque sólo se trate de una decisión de la Corte Interamericana que sostenga el Postulado escogido, se tiene en cuenta la importancia para la protección de los derechos humanos que este último posee, es decir, su fuerza en relación a la tutela efectiva de los derechos y las libertades fundamentales.

Los tres capítulos siguientes (VI, VII y VIII), sistematizan los contenidos descritos en los Capítulos II y III (Derecho Internacional Público y Derecho Internacional de los Derechos Humanos), con los Postulados definidos de acuerdo al Capítulo V, que emergen de la jurisprudencia de la Corte, desarrollada en el Capítulo IV.

Tomamos en cuenta, que el gran tronco común es el Derecho Internacional Público, de donde surge la protección internacional de los derechos humanos. Asimismo, para atender a las exigencias de la protección internacional, se han creado órganos y mecanismos. Uno de ellos es la Corte Interamericana de Derechos Humanos, y de su funcionamiento, nace una rica tarea jurisprudencial.

Dicha labor, permite identificar Postulados que abrevan en el Derecho Internacional general, o en el Derecho Internacional de los Derechos Humanos. Pero los requerimientos del tipo de casos que han llegado al seno de la Corte Interamericana, provocaron la elaboración de otros Postulados que son creación pretoriana de la Corte.

Como vemos, hay un camino recorrido desde la generalidad a la particularidad; la jurisprudencia de la Corte Interamericana, para nosotros, atraviesa esos tres ámbitos definidos, tal como se analizan en los capítulos VI, VII y VIII.

El Capítulo VI elige nueve Postulados aplicados por la Corte Interamericana de Derechos Humanos en su jurisprudencia, tomados de contenidos propios del Derecho Internacional general. Ellos son los siguientes: «Los métodos de interpretación que utiliza la Corte Interamericana, son los mismos que posee el Derecho Internacional general»; «Las restricciones a los derechos, deben hacerse respetando el principio de legalidad»; «Para el acceso a la vía internacional del Sistema Interamericano de Derechos Humanos, debe procederse al agotamiento de los recursos internos»; «Los procedimientos del Sistema Interamericano de derechos humanos, deben llevarse adelante bajo el respeto al principio de seguridad jurídica»; «Los Estados deben respetar y aplicar el principio de buena fe»; "Los tribunales internacionales poseen amplia libertad para evaluar los medios de prueba, sin sujetarse a parámetros estrictos»; «El juez conoce el derecho - iura novit curia - »; «En materia de derechos humanos, rige el principio de continuidad del Estado»; «El daño producido por la violación de una norma de Derecho Internacional engendra el derecho a una reparación adecuada».

Como podemos ver, los Postulados se aplican a casos de protección de derechos y libertades fundamentales (no podría ser de otra forma tratándose de la jurisprudencia de la Corte Interamericana de Derechos Humanos).Por ello, por ejemplo, la legalidad (principio general del derecho y como tal fuente del Derecho Internacional) se adecua a una situación protectiva, y se define como: «Las restricciones a los derechos, deben hacerse respetando el principio de legalidad». 
En el Capítulo VII, se toman cinco Postulados Emergentes de la jurisprudencia de la Corte Interamericana Humanos, que se dirigen a contenidos del Derecho Internacional de los Derechos Humanos, a saber: «Los tratados de derechos humanos tienen una naturaleza propia, disímil de los tratados comunes en el Derecho Internacional»; «Las normas de derechos humanos, deben interpretarse en el sentido más favorable a las presuntas víctimas, y la actuación de los órganos de protección de los derechos humanos, debe realizarse en la misma dirección»; «Los instrumentos o medios procesales destinados a garantizar los derechos humanos, deben ser efectivos»; «Las declaraciones marco de derechos humanos son jurídicamente obligatorias, cuando constituyen la interpretación de los derechos humanos, contenidos en los tratados constitutivos de las Organizaciones Internacionales»; y «Los Estados deben aplicar y respetar, el principio de no discriminación»».

El Capítulo VIII, se refiere a ciertas construcciones de máximas aplicadas a la protección de los derechos humanos, que surgen de las necesidades que provocó la resolución de los casos contenciosos, que llegaron al conocimiento de la Corte Interamericana de Derechos Humanos.

Estas directrices, cuya característica diferencial consiste en que son creación pretoriana del Tribunal, cobran un valor importantísimo, y pasan a formar parte, de a poco, del Derecho Internacional de los Derechos Humanos.

Pongamos el ejemplo de las desapariciones forzadas de personas: al abordar la Corte los primeros casos $\mathbf{2 4}$, tuvo que tipificar este complejo fenómeno de violaciones, acorde a la Convención Americana sobre Derechos Humanos.

Luego de dichas sentencias (aunque no inmediatamente), en el seno de la Organización de los Estados Americanos, se adoptó la Convención Interamericana sobre Desaparición Forzada de Personas, que toma algunos contenidos que la Corte Interamericana había construido en aquella jurisprudencia 25 .

Los cuatro Postulados que consideramos como de creación pretoriana de la Corte Interamericana de Derechos Humanos, son los siguientes: «El ámbito de la función consultiva de la Corte Interamericana es el más amplio posible, dentro de los límites establecidos por la Convención Americana sobre Derechos Humanos»; «Cuando se dan ciertos requisitos, la Comisión debería considerar especialmente, la posibilidad de llevar un caso contencioso ante la Corte Interamericana»; «La desaparición forzada de personas, es una forma compleja de violación de varios derechos fundamentales»; y «Los hijos menores de víctimas de violaciones al derecho a la vida, deben tener asegurado especialmente su derecho a la educación».

Como vemos, los dos primeros se refieren a la actuación de los órganos de control previstos en el sistema (la Comisión Interamericana de Derechos Humanos y la propia Corte), el tercero a un fenómeno de violación, y el cuarto a un contenido de la indemnización debida, cuando ha habido violación de un derecho consagrado en la Convención, y bajo ciertas circunstancias.

En el Capítulo IX, se enuncian las conclusiones que podemos extraer de los ocho capítulos anteriores; con especial énfasis a los rasgos más importantes de los Postulados seleccionados, que proceden de la jurisprudencia de la Corte Interamericana de Derechos Humanos.

Ya hemos hecho referencia, a que el marco jurídico principal de la actuación consultiva y contenciosa de la Corte Interamericana de Derechos Humanos, es la Convención Americana sobre Derechos Humanos (o Pacto de San José de Costa Rica).

La Corte Interamericana, ha jerarquizado en sus decisiones, la obligación contenida en el artículo 1 del Pacto de San José de Costa Rica, porque ésta es un deber general de los Estados partes, sobre todos los derechos consagrados en la Convención Americana.

Es por ello que, en la parte final de este acápite, haremos una sucinta descripción de aquello que ha entendido la Corte Interamericana - de forma general -, como deber de los Estados de conformidad con dicho precepto.

El artículo 1.1 de la Convención Americana sobre Derechos Humanos establece: «... Los Estados Partes en esta Convención se comprometen a respetar los derechos y libertades reconocidos en ella y a garantizar su libre y pleno ejercicio a toda persona que esté sujeta a su jurisdicción...» 26 . 
La Corte, ha interpretado por voluntad propia (sin invocación de las partes al respecto 27 ), el artículo 1.1 de la Convención Americana sobre Derechos Humanos. Así, en el caso Velásquez Rodríguez, el Tribunal elaboró una doctrina al respecto, que luego ha reiterado en numerosas oportunidades.

Para la Corte Interamericana de Derechos Humanos «... El artículo 1.1 es fundamental para determinar si una violación de los derechos humanos reconocidos por la Convención puede ser atribuida a un Estado Parte. En efecto, dicho artículo pone a cargo de los Estados Partes los deberes fundamentales de respeto y de garantía, de tal modo que todo menoscabo a los derechos humanos reconocidos en la Convención que pueda ser atribuido, según las reglas del Derecho internacional, a la acción u omisión de cualquier autoridad pública, constituye un hecho imputable al Estado que compromete su responsabilidad en los términos previstos por la misma Convención...» 28 .

La Corte Interamericana de Derechos Humanos ha desarrollado una jurisprudencia profunda respecto a las obligaciones para los Estados de «respetar los derechos y libertades reconocidos en la Convención»; y de «garantizar el pleno y libre ejercicio de los derechos reconocidos en la Convención» 29.

No es este momento, el propicio para el desarrollo específico de las consideraciones de la Corte en torno de dichas obligaciones; pero algunos de sus contenidos son analizados más adelante, en cuanto constituyen parte integrante de los Postulados que se analizan en los capítulos VI, VII y VIII.

Siguiendo este criterio general descrito, cada vez que la Corte Interamericana de Derechos Humanos ha resuelto en una sentencia, que un Estado ha violado alguno de los derechos establecidos en la Convención Americana, ha dicho expresamente que dicha violación, ha sido hecha en conexión con el artículo 1.1. del Pacto de San José.

La Comisión Interamericana de Derechos Humanos (que es actualmente, junto a los Estados, quien está facultada para elevar los casos contenciosos a la Corte Interamericana), en sus escritos de demanda, solicita que la Corte Interamericana disponga que el Estado acusado, ha violado el derecho que es objeto del planteo «en conexión con el artículo 1.1. de la Convención Americana», recogiendo de esta forma la jurisprudencia general del Tribunal en la materia. 


\section{MARCO GENERAL: DERECHO INTERNACIONAL PUBLICO Y DERECHOS HUMANOS}

Sumario: I.- El surgimiento de la protección internacional de los derechos humanos; II.- las características de la protección internacional; II.1.- La internacionalización; II.2.- La subsidiariedad; II.3.- la irrenunciabilidad; II.4.- La progresividad; III.- Las modificaciones al Derecho Internacional clásico en materia de derechos humanos; III.1.- Soberanía estatal y derechos humanos; III.2.- La subjetividad jurídico internacional del individuo; III.2.a.- La legitimación activa de los actores internacionales; III.2.b.- La legitimación pasiva y la responsabilidad internacional; III.3.- El derecho de los tratados y los derechos humanos; III.3.a.- Tratados y declaraciones; III.3.b.- El objeto de los tratados; III.3.c.- El ius cogens; III.3.d.- Los instrumentos de las cumbres mundiales.

\section{I.- El surgimiento de la protección internacional de los derechos humanos}

La Organización de las Naciones Unidas es una institución, que emerge como producto de la necesidad de regular las relaciones internacionales, que han surgido del fin de la Segunda Guerra Mundial. Los Estados que la han creado le asignaron varios propósitos interrelacionados entre sí, pero jerarquizando el mantenimiento de la paz y la seguridad internacionales.

En efecto, la Carta de la Organización, adoptada en la ciudad de San Francisco, afirma con énfasis en su preámbulo, que los pueblos de las Naciones Unidas se encuentran resueltos a preservar a las generaciones venideras del flagelo de la guerra 30 .

La nueva entidad reemplazó a la antigua Sociedad de las Naciones, a la cual, si bien no puede desconocérsele el mérito de haber constituido el primer intento de Organización Internacional de tipo general, tampoco pueden dejar de señalársele las varias falencias que llevaron al fracaso estrepitoso de la misma, cuyo certificado de defunción podemos datarlo con el inicio de la Segunda Guerra Mundial.

La Organización de las Naciones Unidas ha intentado no repetir los errores de su antecesora; uno de ellos, atinente a la materia que nos ocupa, es el bajo perfil de la entidad en materia de cooperación internacional 31 .

Frente a este panorama, la Carta de las Naciones Unidas contempla entre sus propósitos (o fines establecidos), mantener la paz y seguridad internacionales, fomentar las relaciones de amistad entre las naciones, y lograr la cooperación internacional 32 .

La protección de los derechos humanos, era una necesidad que no podía dejarse de lado al momento de forjar el funcionamiento de la nueva organización. La propia Carta subraya que las Naciones Unidas reafirman su fe, entre otras cosas, en los derechos fundamentales del hombre, la dignidad y el valor de la persona humana, y la igualdad de mujeres y hombres 33 .

Sin pretender aquí ocultar los actuales defectos del sistema de protección instaurado, es dable señalar que en lo relativo a cooperación internacional, las Naciones Unidas han logrado un desarrollo como en ninguna otra esfera.

La sensibilización de la comunidad internacional frente a los crímenes de lesa humanidad cometidos por el nazismo y el fascismo, generaban una presión sobre los miembros de la nueva Organización Internacional, que derivó en la creación de los tribunales penales internacionales de Nuremberg y Tokio, que juzgaron a los máximos responsables de aquellos hechos. 
Se comenzaba a dar forma de esta manera y con el correr del tiempo, a una idea que ha tenido un desarrollo progresivo en el Derecho Internacional. Esta aspiración, se expresa en que las masivas y graves violaciones a los derechos humanos, deben ser tomadas como una suerte de crimen internacional 34 .

La Carta de las Naciones Unidas, otorga competencia general para la atención de las cuestiones relativas a la promoción y protección de los derechos humanos, a su máximo órgano democrático: la Asamblea General 35 .

Sin embargo, la mayor labor en cuanto a la actuación en materia de derechos humanos, se lleva adelante bajo la esfera de otro de sus órganos principales, creado al efecto de atender a la cooperación internacional: el Consejo Económico y Social. Ha sido a partir de la tarea de este órgano, de los organismos especializados y los órganos creados convencionalmente, que se comenzó a tejer la red de protección con que actualmente cuenta la Organización de las Naciones Unidas.

El artículo 68 de la Carta de las Naciones Unidas, ha configurado la llave maestra por medio de la cual, el Consejo Económico y Social, ha abierto la puerta hacia la protección de los derechos humanos. Dicha disposición, le faculta para proceder a la creación de comisiones, en el desempeño de sus funciones.

Así, poniendo en marcha la herramienta que le brindaba el artículo 68 de la Carta de las Naciones Unidas, el ECOSOC ha creado en 1946, al poco tiempo de su propia creación, la Comisión de Derechos Humanos 36.

\section{II.- Las características de la protección internacional}

Señalaremos y reflexionaremos a continuación, sobre cuatro características de la protección internacional de los derechos humanos, a la luz del Derecho Internacional Contemporáneo, y partiendo desde el punto de vista de las Organizaciones Internacionales: la internacionalización, la subsidiariedad, la irrenunciabilidad y la progresividad.

\section{1.- La internacionalización}

Tal como ya hemos mencionado al principio del presente Capítulo las organizaciones y las normas internacionales, son un producto de las necesidades señaladas por las relaciones internacionales, que se encuentran más destacadas en la época en que aquellas surgen; y asimismo, de la voluntad política de los sujetos del Derecho Internacional, que son los únicos habilitados para dar nacimiento a aquellas.

Evidentemente, la segunda contienda bélica mundial, desnudó la falencia y falta de herramientas del Derecho Internacional, para hacer frente a una circunstancia de violación masiva y sistemática de los derechos humanos, cuando esta es practicada por un Estado, en perjuicio de los individuos que se encuentran sometidos a su jurisdicción.

Así, poco a poco, la competencia de la comunidad internacional en materia de derechos humanos se ha ido creando: «... La Segunda Guerra Mundial arrojó como resultado el nacimiento de una conciencia internacional con un postulado central que estipula que la vida, la integridad física y la dignidad de las personas no pueden dejarse a merced de ningún gobierno o Estado. Así, la soberanía o la llamada jurisdicción interna de cada país, ya no entiende exclusivamente en razones de derechos humanos, y no caben como argumentos para impedir la acción internacional, cuando tales derechos son violados...» 37 .

De manera habitual, se debaten y examinan los tópicos, que hacen a la delimitación de competencias nacionales e internacionales en materia de derechos humanos; y, como menciona Frédéric Sudre, se intentan situar las facultades correspondientes dentro de las «esferas propias y en común», que poseen el Estado, de una parte, y las Organizaciones Internacionales, de la otra 38 .

La soberanía de los Estados y el principio de no intervención, han sido siempre argumentados por los gobiernos que cometían violaciones sistemáticas a los derechos humanos, para tratar de impedir las denuncias y las acciones de los órganos internacionales de protección. Pero en materia 
de derechos humanos, a la luz del avance del Derecho Internacional Contemporáneo, ya no cabe para los gobiernos dicha excusa.

Como sostiene Fanny Castro-Rial Garrone, un Estado no puede a la vez considerarse vinculado internacionalmente a la protección de los derechos humanos, y simultáneamente creerse juez de su propio comportamiento, y legitimado para interpretar el principio de no intervención a su antojo 39

La protección de los derechos humanos y el refuerzo del principio de no intervención, no forman parte de una coalición incompatible de ser llevada a cabo; debido a que la protección de los derechos humanos ha sido quitada de la esfera exclusiva del Estado nacional.

Así, la doctrina Jusinternacionalista, coincide en que el principio de no intervención no es invocable «... cuando del accionar de los órganos establecidos en tratados internacionales se trata; tampoco lo es tratándose del accionar de los estados que se ajustan a dichas reglas dentro de los marcos o el seno de dichas estructuras internacionales. Desde luego, quedan a salvo las situaciones en las que jurídicamente puede haber abuso o exceso de poder - abus de pouvoir - e, incluso, desviación de poder, y aquellas otras que se califican como ultra vires...» 40 .

Por ende, la preocupación de la comunidad internacional, (y de las instituciones y órganos internacionales creadas al efecto), forma parte de una atribución legítima de aquella, derivada del orden público internacional (o Ius Cogens) 41 .

La protección de los derechos humanos, es una responsabilidad que se encuentra actualmente compartida, por los Estados nacionales y la comunidad internacional organizada; participando ésta a través de algunas instituciones, órganos y mecanismos, que han sido creados a ese efecto.

En el Capítulo III, se analizan extensivamente los principales instrumentos, órganos y mecanismos existentes para la protección de los derechos humanos a nivel internacional.

\section{2.- La subsidiariedad}

Habiendo señalado que existe la protección internacional de los derechos humanos, es dable expresar aquí, que el Estado sigue manteniendo competencia principal en la materia; de forma tal que la actuación internacional es subsidiaria.

El principio de subsidiariedad, se aplica básicamente a los mecanismos procesales para la protección de los derechos humanos, que están habilitados para activarse cuando dentro del plano nacional la violación en cuestión no se haya remediado 42 .

El mencionado principio de subsidiariedad en la protección de los derechos humanos, ha derivado en una exigencia establecida en los mecanismos de protección, por la cual, es necesario proceder al agotamiento de los recursos internos antes de hacer uso de la vía internacional 43.

\section{3.- La irrenunciabilidad}

La actuación de la comunidad internacional en materia de violaciones a los derechos humanos, a través de los órganos e instituciones creados al efecto, no sólo es legítima y subsidiaria: es, asimismo, irrenunciable.

Este principio, se traduce en que es éticamente inaceptable, que existiendo una situación sistemática de violación de derechos humanos, los órganos internacionales de vigilancia que pueden tomar cartas en el asunto, renuncien a ello. De la misma manera que debe mantenerse el principio de actuación subsidiaria de las Organizaciones Internacionales, debe sostenerse que, llegado el caso, dicha actuación es irrenunciable.

\section{4.- La progresividad}

Otra de las características del Derecho Internacional de los Derechos Humanos, es la progresividad.

Pedro Nikken ha hecho hincapié sobre el carácter progresivo que configura un atributo de la protección internacional de los derechos humanos; y menciona que «... La lectura de los distintos instrumentos de protección a los derechos humanos nos muestra cómo, en algunos de ellos, el contenido de los derechos protegidos, o del tratado mismo en su conjunto, se define previendo una 
extensión progresiva del alcance de la protección protegida. En el primer caso, es posible hablar de derechos de alcance progresivo...» 44 .

Así, y de acuerdo con la teoría esbozada por dicho autor, podemos señalar un aumento progresivo del objeto de los derechos humanos, a través de las nuevas conceptualizaciones del derecho al desarrollo, el derecho al medio ambiente y el derecho a la paz como derechos humanos 45 .

La progresividad en materia de derechos humanos, y en cuanto al objeto, es una tendencia que parece consolidarse en el Derecho Internacional Contemporáneo. En lo que tiene que ver con la progresividad relacionada a los sujetos del Derecho Internacional, aplicada a la protección internacional de los derechos humanos, esta será abordada más adelante.

\section{III.- Las modificaciones al Derecho Internacional clásico en materia de derechos humanos}

El Derecho Internacional Público, en su vertiente clásica, comprendía las relaciones de derecho público, que abarcaban de forma casi exclusiva la distribución de competencias entre los Estados, y la reglamentación de las relaciones entre ellos, siempre en el respeto absoluto de la soberanía nacional.

Los Estados, se convirtieron en sujetos exclusivos y excluyentes de aquel ordenamiento jurídico, cuyo objeto más importante hasta principios del siglo XX, ha sido la regulación de las leyes de la guerra, y el estudio de los tratados y costumbres internacionales.

De igual forma, basado en aquel respeto absoluto al principio de soberanía estatal y comprendiendo de una forma restrictiva toda delegación de competencias, el Derecho Internacional Público se encontró, hasta finales de la segunda guerra mundial, limitado al análisis de las relaciones exteriores y política exterior de los Estados, junto a incipientes normativas e iniciativas, destinadas a regir la convivencia entre aquellos.

Como características de aquel Derecho Internacional clásico, pueden señalarse la desconcentración del poder y una composición oligocrática, con un componente europeísta absoluto 46 .

Era tal el apego al principio de la soberanía estatal, que sólo a partir del fin de la primera guerra mundial, se inició una tímida limitación al recurso a hacer la guerra, con la emergente creación de la primera organización política internacional con vocación universal y de permanencia: la Liga de las Naciones; y la celebración del Pacto Briand Kellogg acordado en 1928 entre Francia y los Estados Unidos. Este instrumento, ha recibido la adhesión posterior de numerosos Estados 47 .

Eduardo Jiménez de Aréchaga, el destacado autor uruguayo, ex integrante de la Corte Internacional de Justicia, destaca que «... El pacto de la Liga de las Naciones introdujo limitaciones parciales en el derecho de los Estados de [recurrir a la guerra] y las partes del tratado Briand Kellogg condenaron [el recurso de la guerra para la solución de las controversias internacionales]...» 48 .

La importancia del Pacto Briand Kellog para el Derecho Internacional Público, radica en que constituye un instrumento claramente precursor, del posterior principio medular de la Carta de las Naciones Unidas: la prohibición o amenaza del uso de la fuerza 49.

Como ya hemos señalado, el final de la Segunda Guerra Mundial dejó al desnudo la barbarie en materia humana, que había sido cometida durante el conflicto bélico. Pero también descubrió, de una manera cruda, el vacío al que dejaba librado el Derecho Internacional a quiénes sufrieran persecuciones de manera sistemática dentro de los Estados.

Hasta dicho momento, y acorde a la evolución señalada, el instituto de Derecho Internacional que se utilizaba, y abarcaba a ciertas personas, era la llamada «protección diplomática» 50 .

El fenómeno de la segunda guerra mundial, que dio lugar a la creación de un nuevo paradigma, tanto en las relaciones internacionales, como en el Derecho Internacional Público, aparejó también la consolidación del derecho de las instituciones internacionales 51 .

La creación de Organizaciones Internacionales, tal como las Naciones Unidas, ha favorecido, asimismo, a la comprensión de que la comunidad internacional no puede quedar ausente en una situación de indefensión de las personas, provocada por una acción voluntaria de un gobierno en 
perjuicio de los derechos elementales de aquellas, y en el marco de una violación sistemática y masiva de los derechos humanos.

Ha colaborado también, al avance en materia de derechos humanos en el campo internacional, el hecho de que este trabajo se ha producido desde el objetivo de la Cooperación Internacional, la cual es llevada a cabo por el Consejo Económico y Social. No puede escapar al análisis que dentro de dicho órgano, no existe el vicio de falta de democratización, que contiene el Consejo de Seguridad de las Naciones Unidas.

El Consejo Económico y Social, lejos de centralizar el poder y la toma de decisiones, ha creado organismos subsidiarios para su tarea (como la Comisión de Derechos Humanos de las Naciones Unidas) 52 , y se ha relacionado con instituciones especializadas intergubernamentales, que son autónomas en cuanto a su funcionamiento, y se dedican a aspectos puntuales de la cooperación internacional 53 .

Así, desde 1945, el Derecho Internacional comenzó a realizar un proceso incesante, de estudio y revisión de los temas concernientes a la determinación de las competencias nacionales e internacionales, en materia de derechos humanos 54 , iniciando un proceso irreversible, que empuja el concepto de soberanía de los Estados hacia una elastización y modificación progresiva del mismo.

Efectivamente, antes de la Segunda Guerra, la relación y el trato de un Estado, respecto a los individuos sometidos a su jurisdicción, eran de exclusiva competencia nacional; pero a partir de la posguerra, la protección de los derechos y libertades fundamentales pasa a ser compartida en los planos nacional e internacional, de tal forma que: «... es menester considerar que la defensa de los derechos fundamentales se desenvuelve en un plano internacional, siendo actualmente una de las ramas más destacadas y poderosas del llamado Derecho Internacional Contemporáneo» 55 .

Podemos afirmar entonces que la tendencia en materia de derechos humanos, ha ido hacia acentuar la creación de instituciones, órganos e instrumentos de protección de derechos humanos, lo cual dota al Derecho Internacional de los Derechos Humanos, de la característica de progresividad 56 .

La aparición del Derecho Internacional de los Derechos Humanos, ha revolucionado al Derecho Internacional clásico, caracterizado por ser un «derecho de coordinación», a diferencia del derecho interno, que reviste la característica de ser un derecho de subordinación. El Derecho Internacional es, esencialmente, de coordinación, debido a que la soberanía de los Estados sigue siendo un principio medular de aquel. De ella, se deriva la libertad de manifestación de la voluntad estatal; es decir, el consentimiento de los Estados, para formar parte de Organizaciones Internacionales, o para ratificar o adherirse a tratados.

La incidencia del Derecho Internacional de los Derechos Humanos en el viejo «derecho de gentes», comprende a sus instituciones principales, tales como el principio de soberanía territorial, el dominio reservado de los Estados, la subjetividad jurídico internacional, y la responsabilidad internacional.

La interacción entre el Derecho Internacional y los derechos humanos es bidireccional; no obstante, en este acápite analizaremos la incidencia del moderno Derecho Internacional de los Derechos Humanos, en el campo del Derecho Internacional Público.

Hemos escogido para examinar algunos aspectos relacionados con la soberanía estatal y los derechos humanos, la subjetividad jurídico internacional del individuo, la incidencia en el derecho convencional internacional; y finalmente, los aportes significativos realizados al Derecho Internacional de los Derechos Humanos, por las llamadas "megaconferencias" de la posguerra fría.

El Derecho Internacional de los Derechos Humanos, a partir de una construcción paciente y novedosa, se ha ganado un lugar visceral, y se ha convertido, finalmente, en un contenido esencial del moderno Derecho Internacional Público.

1.- Soberanía estatal y derechos humanos

Tal como hemos mencionado, el fin de la segunda guerra mundial trajo aparejada una modificación en el esquema de poder de las relaciones internacionales (dando lugar a un 
bipolarismo que ha subsistido durante el período conocido como «guerra fría»), y un cambio en la concepción de «dominio reservado» o absoluto de los Estados.

El dominio reservado está compuesto por ciertas materias que se encuentran ajenas a la vía internacional, y constituyen, esencialmente, algunos aspectos que son substanciales para la formación y la existencia del Estado.

Pero, tal como sostienen Podestá Costa y Ruda, «... a medida que se avanza en el terreno de las relaciones mutuas, la línea de separación entre las atribuciones propias de cada Estado y los intereses de los que constituyen la comunidad internacional se tornó imprecisa y obscura...» 57 .

En materia de derechos humanos, la soberanía de los Estados se ha visto disminuida en su carácter de exclusividad; y la competencia respecto de esta materia es compartida ahora, por el Estado nacional y la comunidad internacional.

En efecto, los derechos humanos se insertan actualmente de forma clara dentro de la llamada «cooperación internacional» entre las naciones, y las Organizaciones Internacionales han ganado terreno progresivamente.

El Estado nacional, mantiene el derecho de prevenir y entender de manera primigenia para resolver los problemas de derechos humanos dentro de sus fronteras. De allí que una regla tradicional en la materia, es aquella que exige la necesidad de proceder al agotamiento de los recursos internos para acceder a la vía internacional.

La regla del agotamiento de los recursos internos, ya se encontraba establecida en el Derecho Internacional general, pero era aplicada a situaciones en las que se veía involucrado un extranjero, frente a un Estado del cual no era nacional.

En materia de derechos humanos, se ha modificado parcialmente esta norma, ampliando su marco de acción también a casos que involucran a nacionales frente a su propio Estado. Así lo prescriben los instrumentos pertinentes de la Organización de las Naciones Unidas, y las normas correspondientes de los textos jurídicos consagrados dentro de los organismos regionales, tales como la Organización de los Estados Americanos, el Consejo de Europa y la Organización de la Unidad Africana 58 .

Como quien tiene primacía en el entendimiento de la cuestión es el Estado nacional, puede afirmarse que la actuación de la comunidad internacional es subsidiaria. Pero naturalmente, si el Estado no remedia correctamente la violación producida, la vía internacional se abre y la competencia de la comunidad internacional es indelegable e irrenunciable en esta materia.

Como afirma en un libro dedicado a la materia el prestigioso internacionalista español Juan Antonio Carrillo Salcedo, a pesar de las modificaciones introducidas por el Derecho Internacional de los Derechos Humanos «... la soberanía de los Estados, principio constitucional del orden internacional, no ha sido desplazada ni por el fenómeno de la organización internacional ni por los derechos humanos, aunque sí erosionada y relativizada. Soberanía de los Estados y derechos humanos son por ello dos principios constitucionales del derecho internacional contemporáneo, que coexisten y se interaccionan recíprocamente en una tensión dialéctica cuya consideración es indispensable para comprender la complejidad y las contradicciones intrínsecas del Derecho Internacional de los Derechos Humanos en la fase actual de su evolución histórica...» 59 .

Podemos entonces afirmar, en el punto que nos encontramos analizando, las siguientes conclusiones:

* Es evidente el cambio que ha introducido la temática de derechos humanos en ciertas instituciones del Derecho Internacional Público, entre ellas, el principio de soberanía de los Estados.

* Asimismo, la protección de los derechos humanos y la evolución de esta cuestión en el plano internacional, colisionan con las concepciones tradicionales de dominio reservado y soberanía estatal.

* Lo anterior, conlleva a redimensionar y volver a definir continuamente los campos y esferas de actuación interna e internacional.

* El principio de soberanía estatal no ha desaparecido, se dinamiza y cambia 60 , y sigue siendo uno de los principales del actual Derecho Internacional Público; aunque las materias que forman su 
contenido y definición, se han modificado en una clara dirección, que se esfuerza por comprender mejor el fenómeno internacional.

2.- La subjetividad jurídico internacional del individuo

En el Derecho Internacional clásico, la subjetividad jurídico internacional está reservada a los Estados en forma exclusiva, es decir: en principio, son los Estados los únicos sujetos o personas del Derecho Internacional.

No hay en la doctrina concordancia de criterios, acerca de si el individuo (o las personas privadas, individuales o colectivas), debe ser considerado un sujeto de Derecho Internacional.

En los dos acápites siguientes, analizaremos la incidencia del Derecho Internacional de los Derechos Humanos, en cuanto a la legitimación activa y pasiva del individuo, dentro del moderno Derecho Internacional Público.

a) La legitimación activa de los actores internacionales

La mayor parte de los autores clásicos (en particular los partidarios de la doctrina dualista y a partir de Triepel y Anzilotti), le niegan al individuo ese carácter, por carecer de derechos y obligaciones internacionales, particularmente "locus standi" ante tribunales internacionales.

Así, Podestá Costa y Ruda, sostienen que la persona privada es objeto de creciente interés internacional, con una tendencia que definen de irreversible, hacia el reconocimiento de derechos y garantías procesales jurisdiccionales al individuo en el campo internacional; pero que no obstante ello, en la actualidad el individuo no debe considerarse sujeto del Derecho Internacional 61.

En el Derecho Internacional, la evolución de la categoría relativa a la subjetividad jurídico internacional, ha planteado el problema respecto a si las Organizaciones Internacionales deben ser también consideradas sujetos plenos o no.

A poco de crearse la Organización de las Naciones Unidas, el mediador designado por la entidad para la cuestión palestina, el conde Folke Bernadotte y su asistente Serot, fueron asesinados; por lo cual la entidad debió hacer frente a cuantiosas indemnizaciones. Debido a ello, la Asamblea General pidió a la Corte Internacional de Justicia, se expida respecto a si la ONU posee capacidad para presentar una reclamación internacional contra un gobierno.

La Corte Internacional de Justicia, en su opinión ha establecido que: «... las Naciones Unidas están destinadas a ejercer funciones y gozar de derechos que no podrían explicarse si no poseyeran personalidad internacional... En consecuencia, la Corte llega a la conclusión que las Naciones Unidas son una persona internacional...» 62 .

La opinión emitida por la Corte en el caso que acabamos de mencionar 63 , ha sido el inicio de la consolidación de las Organizaciones Internacionales como sujetos del Derecho Internacional Público.

Las Organizaciones Internacionales, si bien son en esencia creadas por los Estados, poco a poco han ido adquiriendo independencia de los mismos, autonomía de funcionamiento, identificación de intereses propios $\mathrm{y}$, finalmente, posturas políticas diferenciadas de aquellos que les han dado nacimiento.

Si bien existen diferentes tipos de Organizaciones Internacionales y con distintos grados de desarrollo, las características autonómicas se patentizan más en aquellas que gozan de cierta supranacionalidad en la aplicación de sus políticas, y que poseen órganos realmente propios, y no apéndices de la voluntad nacional de los Estados que las conforman 64 .

El proceso de descolonización, profundizado a partir de la década de 1960, ha favorecido el planteo de la pregunta acerca de si los pueblos deben ser considerados sujetos del Derecho Internacional, tomando como eje el principio de libre determinación 65 (ver página siguiente).

De esta forma, la labor de la Asamblea General de las Naciones Unidas, ha sido categórica al consagrar ya en 1960, que todos los pueblos tienen el derecho de libre determinación; y que en virtud de ese derecho, determinan libremente su condición política, y persiguen libremente su desarrollo económico, social y cultural 66 .

El Derecho Internacional de los Derechos Humanos ha aportado algunos elementos importantes a esta discusión; la adopción de la Declaración sobre Derecho al Desarrollo por la Asamblea 
General de las Naciones Unidas, ha dado un paso trascendente en ese sentido. Este instrumento determina que todo ser humano y todos los pueblos, están facultados para participar en un desarrollo económico, social, cultural y político 67 . También son destacables los avances teóricos del Derecho Internacional en la formulación del llamado "Nuevo Orden Económico Internacional (NOEI)" 68 .

En el ámbito regional, dentro de la Organización para la Unidad Africana, la Carta Africana de los Derechos Humanos y de los Pueblos, establece que los pueblos tienen el derecho a la paz y a la seguridad, tanto en el plano nacional, como internacional 69 .

¿Son hoy los pueblos sujetos del Derecho Internacional? La doctrina mayoritaria del Derecho Internacional es reacia a dicha conclusión, en virtud particularmente de la legitimación activa para ejercer los derechos. Así, Ranjeva y Cadoux sostienen que si bien para los Estados, las Organizaciones Internacionales y las personas privadas, el problema de la personalidad jurídica internacional no muestra grandes dificultades, para los pueblos no se da la misma situación 70 .

Héctor Gros Espiell sostiene que el derecho a la libre determinación de los pueblos puede conceptualizarse como un derecho de la persona humana, y que el hecho de que sea un derecho colectivo, no significa que no pueda ser tomado asimismo como un derecho individual 71 (ver página siguiente).

Algunos autores opinan que los pueblos deben considerarse como sujetos del Derecho Internacional Contemporáneo, tan sólo para ciertos supuestos 72 .

Manuel Díez de Velasco examina la cuestión de la subjetividad internacional de los pueblos, realizando una división de los casos de pueblos sometidos a dominación colonial, y los pueblos constituidos en Estados. En el primer caso, resultado de algunas normas internacionales (Carta de Naciones Unidas, y Resoluciones de la Asamblea General, en particular la Resolución 2625), afirma que en la medida que dichos pueblos tienen un derecho protegido por el orden internacional a liberarse de tal situación, son sujetos del Derecho Internacional, no dándose la subjetividad jurídico internacional de los pueblos en el segundo caso (a pesar que, de todas formas, los pueblos dentro de un Estado posean la autodeterminación pero en modalidades distintas al primer supuesto) 73 .

Luego de una análisis de diferentes acciones llevadas a cabo por algunos movimientos de liberación nacional, Barberis sostiene que: «... los movimientos de liberación nacional son sujetos del derecho de gentes, pues son titulares de derechos y acciones en el plano internacional. Resulta conveniente señalar que la personalidad jurídico internacional de estos movimientos no se funda en las resoluciones de las Naciones Unidas ni en otras disposiciones del orden jurídico de esta organización, sino en actos cumplidos en el ámbito internacional...» 74 .

Sin equipararles a los Estados y a las Organizaciones Internacionales, es evidente que un pueblo posee en la actualidad una capacidad de acción en la esfera de las relaciones internacionales que no los convierte en meros actores. Aún así, no consideramos que pueda hablarse en el momento de una subjetividad jurídico internacional de los pueblos similar a la de los Estados, Organizaciones Internacionales o personas.

¿Qué sucede en cuánto al individuo como sujeto del Derecho Internacional?

Los autores consideran fundamental, para que el individuo esté dotado de esta capacidad, la posibilidad de que éste haga valer mecanismos, para proteger sus derechos humanos en el plano mundial.

Así, Frédéric Sudre sostiene: «... para que el individuo sea un sujeto activo del orden jurídico internacional, es necesario no solamente que sea titular de derechos y obligaciones creadas por el derecho internacional, sino también que le sea reconocida la aptitud de acudir al plano del derecho internacional...» 75 (ver página siguiente).

De igual manera, Eduardo Jiménez de Aréchaga postula que «... La verdadera piedra de toque de la personería jurídica internacional del individuo es atribuirle no sólo ciertos derechos que lo beneficien, sino también los medios de asegurar su ejecución y observancia, y sin la mediación de un Estado...» 76 .

El Derecho Internacional de los Derechos Humanos, ha ido construyendo, paulatinamente, la subjetividad jurídico internacional del individuo, de acuerdo a las características citadas. 
En efecto, dentro de la Organización de las Naciones Unidas, el Primer Protocolo Facultativo Anexo al Pacto Internacional de Derechos Civiles y Políticos, establece que «... Todo Estado Parte en el Pacto que llegue a ser parte en el presente Protocolo reconoce la competencia del Comité para recibir y considerar comunicaciones de individuos que se hallen bajo la jurisdicción de ese Estado y que aleguen ser víctimas de una violación, por ese Estado Parte, de cualquiera de los derechos enunciados en el Pacto...» 77 .

Es decir, el Protocolo mencionado da potestad a las personas para acudir directamente ante el Comité de Derechos Humanos, para tramitar una comunicación, donde el individuo en cuestión se considere perjudicado por una violación a algún derecho, de aquellos que están contenidos en el Pacto Internacional de Derechos Civiles y Políticos.

Además del procedimiento descrito, Carlos Villán Durán explica que, dentro de la Organización de las Naciones Unidas, hay otras dos convenciones que prevén el recurso individual: la Convención sobre la Eliminación de Todas las Formas de Discriminación Racial (que crea el Comité para la Eliminación de la Discriminación Racial), y la Convención Contra la Tortura y Otros Tratos o Penas Crueles, Inhumanos o Degradantes (que crea el Comité contra la Tortura) 78 .

A nivel regional, el Consejo de Europa ha iniciado este camino en los primeros años de la década de 1950. El Convenio Europeo para la Protección de los Derechos Humanos y las Libertades Fundamentales, prevé la posibilidad de que cualquier persona física, organización no gubernamental o grupo de particulares puede demandar a un Estado 79 . Como opina Fanny CastroRial Garrone, el derecho de recurso individual ante la Comisión Europea, es sin duda la mayor innovación del Convenio Europeo, dada la época en que fue sancionado, y las consecuencias de dicho reconocimiento del recurso individual para el Derecho Internacional 80 .

El Protocolo IX Anexo al Convenio Europeo, ha significado un gran avance, toda vez que otorga una legitimación (aún imperfecta) al individuo frente a una instancia jurisdiccional: tal como hemos sostenido «... respecto al artículo 25 del Convenio Europeo, el Protocolo número 9 supone un avance en el papel del individuo en la defensa de los Derechos Humanos en el sentido de concederle dos prerrogativas procedimentales de primera magnitud. De un lado, el derecho de deferir una demanda individual al Tribunal, lo cual no conllevará en cambio derecho a obtener un examen sobre el fondo de la misma... Por otro lado, nos estamos refiriendo a la mejora de las garantías concedidas al individuo durante el desarrollo del procedimiento ante el Tribunal Europeo, lo cual tampoco supondrá un «locus standi» asimilable al reconocido para los Estados. Así, por ejemplo, aunque el Protocolo no lo menciona expresamente, el derecho de los individuos de llevar un asunto ante el Tribunal sólo podrá realizarse en el caso de las demandas declaradas admisibles por la Comisión...»81 .

Actualmente, la adopción del Protocolo XI al Convenio Europeo (aún no ha entrado en vigor), otorga al individuo la capacidad de acudir por sí directamente a una instancia jurisdiccional; ya que la reforma propuesta, tiene como contenido la eliminación de la actual Comisión Europea de Derechos Humanos, y la división del Tribunal en diferentes instancias jurisdiccionales 82 .

Dentro de la Organización de los Estados Americanos, podemos observar la legitimación activa más amplia en materia de derechos humanos, toda vez que cualquier persona, grupo de personas o entidad no gubernamental legalmente reconocida en uno o más estados miembros de la OEA, puede peticionar a la Comisión Interamericana, con denuncias o quejas de violación a los derechos protegidos en la Declaración Americana de Derechos y Deberes del Hombre, o en la Convención Americana 83 .

Es decir, para acudir al sistema interamericano, no es necesario reputar la calidad de víctima (como ante el sistema instaurado en el Consejo de Europa), ni tampoco que el Estado en cuestión haya ratificado ningún tratado específico de derechos humanos, bastando con que sea miembro de la Organización de los Estados Americanos.

La amplia legitimación activa y las facultades de la Comisión Interamericana, son dos características que deben mantenerse, para una mayor eficacia en la protección de los derechos humanos en el continente: ambas cuestiones son «... características sobresalientes del sistema...» 84 
Es evidente, entonces, que en el desarrollo del actual Derecho Internacional de los Derechos Humanos, el individuo se encuentra revestido de la categoría de sujeto de Derecho Internacional. Tal como sostiene Pastor Ridruejo «... el individuo posee, pues, una subjetividad cierta, aunque limitada, que tiene lugar dentro de marcos convencionales... 85 .

No puede omitirse, por la importancia que tiene, la reciente reforma al reglamento de la Corte Interamericana de Derechos Humanos, donde se acepta por primera vez en el sistema interamericano, el locus standi para la víctima o su representante, en la etapa de reparaciones ante dicho Tribunal: «... En la etapa de reparaciones los representantes de las víctimas o de sus familiares podrán presentar sus propios argumentos y pruebas en forma autónoma...» 86 .

El individuo es, para el Derecho Internacional Contemporáneo, algo más que un mero actor. Esto no significa en modo alguno, equipararlo al Estado ni a las Organizaciones Internacionales; pero es notorio que, con una capacidad y legitimación limitada (tanto de tipo activo, como pasivo, según veremos seguidamente), el individuo reviste las condiciones para ser considerado un sujeto del Derecho Internacional Público actual.

b) La legitimación pasiva y la responsabilidad internacional

El Derecho Internacional clásico aborda la teoría de la responsabilidad internacional, considerando que la comisión de un acto ilícito internacional da lugar a la responsabilidad de los Estados y, por analogía en algunos casos, a la responsabilidad de las Organizaciones Internacionales.

En el Capítulo VI del presente trabajo, abordamos la responsabilidad internacional, trabajada desde la jurisprudencia de la Corte Interamericana de Derechos Humanos 87 .

La responsabilidad, según Juan Carlos Puig, es individual en el Derecho Internacional, cuando la represión - ora como obligación legal de reparar daños causados, ora como sanción - va dirigida contra el mismo individuo que cometió el hecho ilícito 88 .

Sin entrar en la consideración, respecto a si las violaciones al Derecho Internacional Humanitario engendran responsabilidad internacional para el Estado, para el individuo o para ambos, no deben dejar de analizarse los recientes avances producidos desde la creación de los Tribunales Ad Hoc para el juzgamiento penal de personas que han incurrido en dichas violaciones, a raíz de los conflictos armados sucedidos en los territorios de la Ex Yugoslavia y en Rwanda 89.

No es casual que las creaciones de los tribunales mencionados, hayan sido realizadas por el Consejo de Seguridad de las Naciones Unidas, en una de las manifestaciones más claras del nuevo paradigma internacional de la posguerra fría. En efecto, sostenemos que «... el nuevo escenario internacional y el destrabe de la lucha ideológica bipolar en las relaciones entre los Estados, han producido un vuelco hacia la conjunción de la problemática de la paz internacional y el respeto de los derechos humanos...» 90 .

También se responde a un fenómeno, que el Derecho Internacional de los Derechos Humanos considera pernicioso para el valor justicia, y compromete el futuro de las sociedades: la impunidad. Es por ello, que se busca el objetivo de asegurar que los perpetradores de ciertos crímenes, sean responsabilizados penalmente por los hechos que hayan cometido.

El Tribunal Internacional para la ex Yugoslavia 91, ha sido establecido con la finalidad exclusiva de juzgar presuntos responsables de crímenes contra el Derecho Internacional Humanitario, cometidos en el territorio de la Ex Yugoslavia, a partir del 1 de enero de 1991.

El Consejo de Seguridad de las Naciones Unidas, ha determinado la competencia de dicho Tribunal, el cual entiende en las violaciones a los Convenios de Ginebra de 1949, a las leyes de la guerra terrestre de la Cuarta Convención de La Haya de 1907, y a la Convención contra el Genocidio adoptada en 1948 por las Naciones Unidas 92 (ver página siguiente) .

El Tribunal internacional para Rwanda, también respondió a situaciones aberrantes, denunciadas en particular por los informes de una comisión independiente de expertos, que en 1994 señaló actos de genocidio de Hutus contra Tutsies, y la violación de ambas partes del Derecho Internacional Humanitario.

La Resolución 955 (1994), del Consejo de Seguridad, determina el establecimiento del Tribunal, con la finalidad exclusiva de juzgar presuntos responsables de genocidio y otros crímenes contra el 
Derecho Internacional Humanitario, cometidos en Rwanda o Estados vecinos, contra ciudadanos de Rwanda.

La competencia del Tribunal, en razón de la materia, comprende el juzgamiento de actos de genocidio conforme a la Convención contra dicho crimen, los Convenios de Ginebra de 1949 (en particular su artículo 3 común), y las violaciones producidas al Protocolo Adicional II Anexo a los Convenios de Ginebra.

Asimismo, dentro de la Organización de las Naciones Unidas, se ha retomado con fuerza la idea de crear una corte penal internacional con carácter permanente, a tal punto que un Comité Preparatorio se encuentra redactando el borrador de estatuto para el funcionamiento de dicho tribunal. El texto final del mismo, será decidido definitivamente por una conferencia de plenipotenciarios, a celebrarse en Roma, a partir del mes de junio de 1998.

En las discusiones actuales, se observa una tendencia a ir más allá, incluso, que la competencia de los tribunales penales que se han conocido hasta la fecha (Nuremberg, Tokio, Ex Yugoslavia y Rwanda); y se prevé, por ejemplo, que violaciones a la Convención contra la Tortura, puedan ser juzgadas en determinadas circunstancias por la Corte.

Desde el punto de vista de la legitimación activa y pasiva en el Derecho Internacional Contemporáneo, observamos entonces que, si bien el Estado es el sujeto pleno del Derecho Internacional Público, y sigue siendo el principal edificador del mismo, ha surgido el individuo como incipiente sujeto de derecho en este campo jurídico, ocupando un lugar propio; y se observa, asimismo, con el correr del tiempo, una inclinación hacia el aumento de su esfera de acción.

Como conclusión de este punto, puede inferirse que, en la actualidad, los sujetos del Derecho Internacional Público son el Estado, las Organizaciones Internacionales y el individuo.

Las Organizaciones Internacionales son sujetos del Derecho Internacional, porque dicha subjetividad es necesaria para el cumplimiento de sus funciones; pero la misma razón que le da nacimiento a la subjetividad internacional de las Organizaciones Internacionales, es la que le pone límites: las Organizaciones Internacionales no poseen más subjetividad jurídico internacional, que la capacidad para actuar de acuerdo a sus fines constitutivos.

El individuo ya no puede ser tomado como un mero objeto del Derecho Internacional; su capacidad de obrar en este plano se ha consolidado, hasta en ciertos procedimientos ante etapas jurisdiccionales. El individuo es, entonces, sujeto del Derecho Internacional, aunque dicha subjetividad, está circunscrita a la protección internacional de los derechos humanos.

En cuanto a los Pueblos, son actores principales del Derecho Internacional, y poseen legitimación en algunos aspectos limitados, tienen subjetividad jurídica internacional, pero limitada y temporal, debido a que, como entidad, son jurídicamente transitorios, ya que luego de ejercer la autodeterminación, pasan a formar parte de un Estado nuevo, o se adhieren a un Estado ya formado.

3.- El derecho de los tratados y los derechos humanos

La disciplina referente a los derechos humanos, ha introducido modificaciones substanciales al Derecho Internacional convencional clásico; es decir, el llamado «derecho de los tratados», establecido y regulado en las Convenciones de Viena que rigen la materia 93 .

Conforme a la Convención de Viena de 1969, un tratado es un acuerdo internacional, celebrado entre Estados por escrito, y regido por el Derecho Internacional; ya conste en un instrumento único, o en dos o más instrumentos, y cualquiera sea su denominación particular 94 .

Max Sorensen, construye una definición del objeto de los tratados, estableciendo que «... la esencia de los tratados, ya se consideren como instrumentos o como negociaciones, según la regla general referida, constituye la fuente específica de una obligación de derecho internacional contraía voluntariamente por una persona de derecho internacional en favor de otra u otras, y que da a su vez, derechos recíprocos para ella o ellas...» 95 .

Una cuestión que hace a los tratados de derechos humanos, y que merece un abordaje a realizar desde puntos de vista más avanzados que los que existen en el Derecho Internacional clásico, es el de las reservas. No nos referiremos aquí a dicho tema, pero consideramos importante limitar más claramente, y más allá de las previsiones de la Convención de Viena sobre Derecho de los Tratados 
(que estipula un engorroso sistema de vigilancia interestatal), a la capacidad de los gobiernos para formular reservas. Un buen punto de partida, sería otorgarle a los órganos de supervisión, la facultad de interpretar cuáles reservas, están prohibidas por el objeto y fin del tratado, tal como ha sucedido dentro del sistema europeo96.

Existen marcados aportes y modificaciones, al derecho clásico de los tratados, efectuados desde el punto de vista de la protección internacional de los derechos humanos; seguidamente nos referiremos a algunos de ellos.

a) Tratados y declaraciones

El Derecho Internacional Público clásico, en materia convencional, distingue claramente entre tratados (o convenciones) y declaraciones, particularmente en cuanto a sus efectos.

Un tratado o convención, en tanto requiere un proceso de adopción, negociación, firma, ratificación y requisitos para su entrada en vigor; es jurídicamente obligatorio para los Estados que voluntariamente, han decidido someterse a él. Generalmente, su incumplimiento constituye una violación del Derecho Internacional y, en determinados casos, engendra la responsabilidad de los Estados.

Una declaración es, para el Derecho Internacional clásico, una aspiración de deseos, una manifestación de voluntad, un direccionamiento moral; pero que no engendra en grado alguno obligatoriedad jurídica, para los Estados que han votado la misma por medio de una resolución dentro de una Organización Internacional; y, naturalmente, su incumplimiento no engendraría responsabilidad internacional para los Estados.

El Derecho Internacional de los Derechos Humanos ha venido a disminuir tal categórica afirmación (que se mantiene en su esencia). En efecto, tal como sostiene O' Donnell «... Una de las máximas del Derecho Internacional clásico - que se aplica al Derecho Internacional de los derechos humanos con importantes reservas - es la distinción hermética entre los tratados como instrumentos obligatorios y las declaraciones como no obligatorias...» 97 .

Como vemos, la gran mayoría de las declaraciones sobre derechos humanos siguen siendo no vinculantes para los Estados, jurídicamente hablando. Sin embargo, dos de ellas han adquirido la característica de obligatoriedad.

En primer lugar, cabe referirse a la Declaración Universal de los Derechos Humanos, aprobada en 1948 por la Asamblea General de las Naciones Unidas 98 .

La obligatoriedad jurídica de la Declaración Universal de los Derechos Humanos ha sido subrayada por la Proclamación de Teherán, la cual dice «... La Declaración Universal de Derechos Humanos enuncia una concepción común a todos los pueblos de los derechos iguales e inalienables de todos los miembros de la familia humana y la declara obligatoria para la comunidad internacional...» 99 .

Asimismo, algunos autores como Hitters, le dan el carácter de costumbre como fuente de derecho «... las prerrogativas allí enunciadas [ se refiere en la Declaración ] se han convertido en derecho consuetudinario internacional por conducto de la práctica estatal y de la opinio iuris...» 100

Juan Antonio Carrillo Salcedo, también analizando la cuestión atinente a la obligatoriedad de la Declaración Universal, ofrece una interesante visión, sobre al contenido de dicho instrumento, como parte de los principios generales del derecho 101 .

¿Porqué es importante que la Declaración Universal de Derechos Humanos sea de cumplimiento jurídico obligatorio? La respuesta es sencilla, desde el punto de vista de la necesidad de la protección de las víctimas: los Estados que no han ratificado los tratados de derechos humanos, no se verían sometidos al respeto a ningún instrumento, y la protección de los individuos sometidos a su jurisdicción, quedaría fuera de cobertura internacional.

Es así que dentro de la Organización de las Naciones Unidas, se han desarrollado los llamados procedimientos extraconvencionales (conocidos como Procedimientos 1503 y 1235) que aplican como instrumento jurídico, a la Declaración Universal de Derechos Humanos, y se llevan adelante ante la Subcomisión, y la Comisión de Derechos Humanos 102. 
La Declaración Universal de Derechos Humanos ha devenido, entonces, de cumplimiento jurídico obligatorio para todos los Estados miembros de la Organización de las Naciones Unidas; en primer lugar porque es aplicable por algunos órganos (como acabamos de mencionar); y finalmente porque se ha transformado en una norma consuetudinaria, o porque algunos de sus contenidos forman parte de los llamados principios generales del derecho, y por ende constituyen fuentes principales del Derecho Internacional, según el Estatuto de la Corte Internacional de Justicia.

En el ámbito regional, correspondiente a los miembros de la Organización de los Estados Americanos, la Declaración Americana de los Derechos y Deberes del Hombre (de 1948), también posee carácter de obligatoriedad, para todos los integrantes de la entidad, y sin el requerimiento de que estos hayan ratificado algún tratado de protección de los derechos humanos.

Efectivamente, la Comisión Interamericana de Derechos Humanos, aplica la Declaración en los casos que tramita; y afirma en sus resoluciones, cuando encuentra a un Estado culpable, que dicho Estado ha violado las obligaciones que emanan de dicha Declaración. Así lo ha resuelto la Comisión Interamericana, al dictaminar que los Estados Unidos violaron los artículos I y II de la Declaración (Derechos a la vida y a la igualdad), al haber ejecutado bajo pena de muerte, a dos personas que cometieron delitos condenables con la pena capital, antes de cumplir los dieciocho años de edad, en los estados de Carolina del Sur y Texas 103.

Asimismo, la Corte Interamericana de Derechos Humanos ha tenido oportunidad, al emitir una opinión, de mencionar que su facultad de interpretación de la Declaración Americana de Derechos Humanos, en ejercicio de su función consultiva, obedece a que la Declaración Americana, constituye la expresión de los derechos humanos, que se encuentran contenidos en la Carta de la Organización de los Estados Americanos 104.

Cabe concluir en este punto, entonces, que algunas declaraciones de derechos humanos, más precisamente la Declaración Universal dentro de la Organización de Naciones Unidas, y la Declaración Americana de Derechos y Deberes del Hombre dentro de la Organización de los Estados Americanos, poseen fuerza jurídica vinculante, y su incumplimiento da lugar a una sanción internacional, aunque no a un resarcimiento con carácter compulsivo. De esta manera, se modifica parcialmente aquel axioma del derecho clásico, por el cual una de las diferencias entre tratados y obligaciones, era la obligatoriedad jurídica de que estaban revestidos los primeros.

La jurisprudencia de la Corte Interamericana de Derechos Humanos, en relación a la Declaración Americana sobre Derechos y Deberes del Hombre, se analiza en el Capítulo VII 105.

b) El objeto de los tratados

En el Derecho Internacional clásico, los tratados tenían como objeto, la regulación de las relaciones entre los Estados intervinientes en el mismo; en particular, el canje correlativo de derechos, que otorgaban ventajas a las diferentes partes que ratificaban el acuerdo.

Los ejemplos más típicos de dicha esfera de tratamiento, están dados por los acuerdos sobre delimitación de fronteras, el intercambio comercial, ciertas normas sobre la guerra, o la delimitación de los espacios marítimos.

La particularidad de los convenios de derechos humanos, es señalada, tanto por los doctrinarios, como por algunos órganos internacionales. En el primero de los casos, Dupuy precisa que los titulares de los derechos humanos, son por regla general los individuos, aisladamente o de forma colectiva; pero los destinatarios de las obligaciones correlativas a los derechos humanos, son los Estados. Por ende, el principio de reciprocidad que rige en el Derecho Internacional común no tiene vigencia en este campo 106 .

En segundo lugar, la temática de derechos humanos ha introducido una nueva serie de instrumentos convencionales, cuya característica, ha definido con precisión la Corte Interamericana de Derechos Humanos, en el ejercicio de su función consultiva.

En efecto, dicho Tribunal, ha afirmado que «... Los tratados modernos sobre derechos humanos, en general, y en particular la Convención Americana, no son tratados multilaterales de tipo tradicional, concluidos en función de un mutuo intercambio recíproco de derechos, para el beneficio mutuo de los Estados contratantes. Su objeto y fin es la protección de los derechos fundamentales de los seres humanos, independientemente de su nacionalidad, tanto frente a su propio Estado como 
frente a los otros Estados contratantes. Al aprobar estos tratados sobre derechos humanos, los Estados se someten a un orden legal dentro del cual ellos, por el bien común, asumen varias obligaciones, no en relación con otros Estados, sino hacia los individuos sometidos a su jurisdicción...» 107 .

La Corte Interamericana, ha sabido interpretar correctamente, esta modificación clara que ha introducido el Derecho Internacional de los Derechos Humanos, al derecho convencional clásico: los obligados en los convenios de derechos humanos, son los Estados respecto de los individuos que se encuentran bajo su jurisdicción; lo cual le otorga a éstos últimos ciertas prerrogativas dentro del Derecho Internacional 108 .

Asimismo, se observa una tendencia dentro de los últimos instrumentos de protección de los derechos humanos, a la búsqueda de la adopción de determinadas conductas, por parte ya no sólo de los Estados, sino también de los individuos. En ese sentido, la reciente Convención Interamericana para la Eliminación, Sanción y Erradicación de la Violencia contra la Mujer, postula que toda mujer «... tiene derecho a una vida libre de violencia, tanto en el ámbito público como en el privado...» 109 .

Es a todas luces evidente, que la particularidad que hace a la materia de la protección internacional de los derechos humanos, amplía los límites del Derecho Internacional convencional en cuanto al objeto central de los acuerdos (que es sin duda la salvaguarda de las víctimas), y algunas de sus otras prescripciones principales.

c) El ius cogens

El llamado ius cogens, es definido en la Convención de Viena sobre Derecho de los Tratados, como una norma imperativa de Derecho Internacional general; aceptada y reconocida por la comunidad internacional de Estados en su conjunto, como una norma que no admite acuerdo en contrario 110 .

Varios prestigiosos autores se han referido al concepto y contenido del ius cogens, o el también llamado orden público internacional 111 .

¿Puede decirse que todo el contenido del actual Derecho Internacional de los Derechos Humanos, forma parte del llamado ius cogens? Sería exagerado realizar tal afirmación, toda vez que una norma de ius cogens, no admite derogación ni suspensión alguna, (además sólo puede ser modificada por otra norma de igual carácter), y los instrumentos internacionales de derechos humanos (tanto universales como regionales) poseen cláusulas que prevén la suspensión de ciertos derechos y garantías.

Es por ello, que Carrillo Salcedo introduce el concepto de «núcleo duro de derechos humanos», manifestando que existen ciertos derechos humanos, que deben reputarse fundamentales y absolutos y que por ende, no son susceptibles de limitaciones y derogaciones 112 .

Así, siguiendo a dicho autor, aquellos contenidos de derechos humanos que forman parte del ius cogens, debemos buscarlos en los preceptos de los instrumentos internacionales de protección de los derechos humanos, que establecen cuáles son los derechos, que no pueden ser suspendidos en ningún caso; es decir, en el artículo tercero de las Convenciones de Ginebra de 1949 sobre Derecho Internacional Humanitario, en el artículo quince del Convenio Europeo de Derechos Humanos, en el artículo cuarto del Pacto Internacional de Derechos Civiles y Políticos; y finalmente, en el artículo veintisiete de la Convención Americana sobre Derechos Humanos.

De igual forma, luego de un profundo análisis de la cuestión, Travieso sostiene que «... la doctrina y la práctica internacional expuestas, verifican un método de producción suficiente para inscribir en el ius cogens a los derechos humanos fundamentales mediando entre ellos una relación de género a especie...» 113 .

Algunos otros autores, consideran inapropiado darle a ciertos derechos humanos el carácter de ius cogens; así Sudre, considera que el concepto de ius cogens está restringido al derecho de los tratados, y definido por su vertiente negativa: todo tratado contrario al ius cogens es nulo. De igual manera, considera que la confusión que hace al ius cogens en general, puede terminar confundiendo un dominio como el de los derechos humanos, que debe ser lo más claro posible; finalmente, 
sostiene que el ius cogens, presupone una necesaria jerarquización que va contra la doctrina actual de la indivisibilidad e interdependencia de todos los derechos humanos 114 .

En nuestra opinión, el aporte de los derechos humanos, enriquece y aumenta el contenido del ius cogens, orden público internacional, del cual ningún gobierno puede apartarse; porque su violación, significa ir en contra de principios, que son considerados intransigibles y fundamentales por la comunidad internacional en su totalidad.

Sin dejar de considerar las dificultades expresadas por Sudre, creemos por el contrario que dotar a ciertos derechos de la categoría de ius cogens, le da una gran importancia a la protección internacional de los derechos humanos.

Lo anterior no implica necesariamente una negación de la indivisibilidad de los derechos humanos. No existen derechos más importantes, ni un Estado puede ampararse en el cumplimiento de algunos, para dejar de cumplir otros. Pero es claro que en el desarrollo del Derecho Internacional Contemporáneo de los derechos humanos, hay ciertos preceptos, que poseen reconocimiento y mecanismos de protección más eficaces. Pero ello no se debe a que los derechos humanos puedan ser considerados divisibles, sino a la progresividad del reconocimiento y tutela, de los diferentes tópicos que contiene la protección internacional de los derechos humanos.

d) Los instrumentos de las cumbres mundiales

Las relaciones internacionales de la posguerra fría, han traído al centro de la escena internacional, las llamadas grandes conferencias, sobre temáticas que escapan a las fronteras de un Estado, y constituyen una preocupación legítima de toda la comunidad internacional.

De esta forma, el medio ambiente, la población en relación al desarrollo, los derechos humanos, el desarrollo social, la problemática de la mujer, los asentamientos urbanos, etc.; han sido objeto de un tratamiento privilegiado, en foros donde han coincidido una gran cantidad de actores estatales y no estatales, para la discusión y adopción por parte de los Estados, de instrumentos que posibiliten encontrar soluciones a los problemas planteados.

En general, los documentos emanados de dichos encuentros, llevan por título el de "declaración", "programa" o "plataforma de acción", aunque en algunos de ellos se han adoptado también convenciones 115 .

Dichos instrumentos, aportan un contenido renovador al Derecho Internacional, e inducen implícitamente su tratamiento y aplicación progresiva, por parte de los órganos que componen diversas esferas, en la Organización de las Naciones Unidas.

La Conferencia de Viena de 1993, ha tenido como objeto central, el estudio de la situación y la protección de los derechos humanos; en ella se aprobaron la Declaración, que consta con 39 puntos, y el Programa de Acción de Viena que contiene 100 puntos; ambos instrumentos, fueron adoptados por consenso, por los representantes de los Estados que han participado del encuentro 116 .

La Cumbre Mundial sobre Población y Desarrollo, llevada adelante en la ciudad de El Cairo en 1994, tuvo como objetivo realizar un enfoque conjunto y no antagónico de los factores población y desarrollo. Dentro de la misma, se abordaron aspectos tales como las relaciones entre la población, el crecimiento económico sostenido y el desarrollo sostenible; la igualdad de género, equidad y capacitación de la mujer; la familia, sus papeles, composición y estructura; el crecimiento y estructura de la población; los derechos reproductivos y planificación de la familia; la salud, morbilidad y mortalidad; la distribución de la población, urbanización y migraciones internas; las migraciones internacionales; cuestiones atinentes a población, desarrollo y educación; tecnología e investigación; acción nacional y cooperación internacional y la colaboración con el sector no gubernamental 117 .

La Cumbre sobre Población y Desarrollo, produjo como instrumento el Programa de Acción de El Cairo 118 .

La Cumbre Mundial sobre Desarrollo Social, se celebró en Copenhague, Dinamarca, en marzo de 1995. El objeto de la Cumbre, fue encontrar las herramientas para colocar al ser humano en el centro del desarrollo; proteger al medio ambiente y dar pautas para su utilización de forma sostenible; buscar la integración de las políticas económicas, culturales y sociales; promover la democracia, los derechos humanos y la solidaridad; propiciar la distribución equitativa de los 
ingresos; reconocer y apoyar a las poblaciones indígenas; fortalecer la familia en sus diversas formas; mejorar los grados de participación de la mujer en todas las esferas; y abordar la problemática de los refugiados y desplazados 119 .

Los instrumentos que han surgido de la Cumbre Mundial sobre Desarrollo Social, son la Declaración y el Programa de Acción de Copenhague; en el Programa de acción se indican políticas y medidas dirigidas a poner en práctica los principios, y cumplir los compromisos enunciados en la Declaración de Copenhague sobre Desarrollo Social 120 .

La Cuarta Conferencia Mundial sobre Derechos de la Mujer se llevó a cabo en setiembre de 1995 en la ciudad de Pekín121; sus objetivos fueron avanzar hacia la meta de igualdad entre las mujeres y los hombres, y abordar fenómenos tales como la discriminación en razón del género, la violencia contra la mujer, su acceso a la educación y a servicios de salud; la pobreza extrema y el analfabetismo, que afectan mayoritariamente a las mujeres. Esta conferencia «... muestra como resultado un ambicioso plan de acción que debe ser llevado a cabo dentro de los campos internacional, regional y nacional para cumplir sus objetivos...» 122 .

Finalmente, en el encuentro se adoptaron la Declaración y la Plataforma de Acción de Pekín 123

En todos los foros mencionados se han debido abordar temas que conciernen directamente a la promoción y protección de los derechos humanos 124 . Esta «diplomacia de las megaconferencias», llevada a cabo a través de la actividad de las Naciones Unidas, aportó una notoria aparición del Derecho Internacional Contemporáneo de los Derechos Humanos, en la actual discusión diplomática internacional.

Cabe mencionar aquí, que tanto la Declaración y el Programa de Acción de Viena; El Programa de Acción de El Cairo; la Declaración y el Programa de Acción de Copenhague; y la Declaración y la Plataforma de Acción de Pekín; fueron adoptados por el consenso de los Estados presentes en dichos foros mundiales.

Los textos emanados no pueden, sin duda, ser equiparados a tratados internacionales; pero adquieren significado como instrumentos internacionales de gran validez.

Tal como sostiene Carrillo Salcedo, «... el proceso de institucionalización de la sociedad internacional que las Organizaciones Internacionales representan ha modificado los rasgos de descentralización y falta de institucionalización que caracterizan el derecho internacional, por lo que hoy no es posible plantearse el problema de la elaboración del derecho en el medio internacional sin tener en cuenta la influencia de las Organizaciones Internacionales en la positivización de las normas jurídicas internacionales...» 125 .

En efecto, el aporte que las Conferencias Internacionales celebradas por la iniciativa de las Naciones Unidas puede dar lugar a la formación de costumbres o de convenciones internacionales, como fuentes principales del Derecho Internacional Público.

Quisiéramos destacar dos datos que consideramos muy importantes para el punto que estamos tratando aquí.

En primer lugar, el hecho de que en las conferencias mundiales, se encontró presente una representación internacional genuina a nivel cultural, político, social y económico.

En segundo lugar, la relevancia que tiene el hecho de que los instrumentos emanados de dichos encuentros, han sido aprobados por consenso internacional de todos los participantes (sin dejar, por cierto, de tener en cuenta ni restarle valor a las diferentes interpretaciones y reservas, realizadas por algunas delegaciones gubernamentales a ciertos documentos, en particular los aprobados en las cumbres de El Cairo y Pekín).

De hecho, creemos que estos instrumentos son hoy fuentes subsidiarias del Derecho Internacional, que pueden servir para complementar a otras fuentes principales en la aplicación, por parte de los órganos pertinentes, del Derecho Internacional Público, y que pueden formar parte del contenido de algunas de las fuentes principales, ya sean costumbres o tratados. 


\section{RELACIONES ENTRE LA PROTECCION INTERNACIONAL Y LA PROTECCION REGIONAL DE LOS DERECHOS HUMANOS. INTRODUCCION A LOS ORGANOS Y SISTEMAS REGIONALES}

Sumario: I.- La protección internacional y regional de los derechos humanos; II.- Los sistemas regionales de protección; II.1.- La Liga de Estados Arabes; II.2.- El Consejo de Europa; II.3.- La Organización de la Unidad Africana; II.4.- La Comunidad de Estados Independientes; II.5.- La Organización de los Estados Americanos; III.- Los mecanismos de protección de los derechos humanos; III.1.- La protección convencional III.1.a.- Mecanismos no contenciosos; III.1.b.- Mecanismos cuasicontenciosos; III.1.c.Mecanismos contenciosos; III.2.- La protección extraconvencional; III.3.- Los órganos de protección; III.2.a.- órganos de tipo administrativos; III.3.b.- Organos jurisdiccionales. Introducción.

\section{I.- La Protección internacional y regional de los derechos humanos}

De la misma forma que en el Capítulo anterior, se expresara que diversos factores y necesidades han influido en la conformación de las Naciones Unidas y en la tarea desarrollada por esta en pro de los derechos humanos, debe señalarse aquí, que similares factores y necesidades, han favorecido la expansión de la protección de los derechos humanos dentro de las Organizaciones Internacionales regionales.

Simultáneamente, dentro de cada una de las organizaciones internacionales (regionales o mundiales), se realiza el debate en torno a cómo deben protegerse los derechos humanos. Las Naciones Unidas, comenzaron este trabajo con la creación de la Comisión de Derechos Humanos 126, y la sanción el 10 de diciembre de 1948, de la Declaración Universal de Derechos Humanos 127 .

No ha sido fácil que los representantes de los Estados se pongan de acuerdo sobre normas que puedan inculpar a los propios Estados; por otra parte, las interpretaciones intencionadas acerca de las diferentes culturas y religiones que conviven dentro de las Naciones Unidas, también han conspirado contra un «entendimiento universal» en materia de derechos humanos.

Las virtudes y defectos del sistema de protección de derechos humanos en las Naciones Unidas, han sido evaluados en junio de 1993 en la Conferencia Mundial sobre Derechos Humanos, convocada para examinar los problemas a que hace frente la organización para promover y proteger, esos derechos y libertades que se consideran fundamentales e inherentes a la persona 128 .

Lo señalado, no significa necesariamente, que deba considerarse que los sistemas regionales (por la afinidad cultural de sus integrantes), son más efectivos que el sistema internacional. De hecho, se trata de diferentes mecanismos que han tenido un desenvolvimiento autónomo (sin dejar de reconocer las influencias recíprocas).

Podemos decir que, por ejemplo, Naciones Unidas no posee un mecanismo jurisdiccional de protección de derechos humanos tal como conocemos en los sistemas interamericano y europeo 129 
Por otro lado, y tal como veremos, los sistemas africano, árabe, y el instaurado dentro de la Comunidad de Estados Independientes, son más débiles que el establecido en Naciones Unidas.

La región Asia Pacífico, no cuenta aún con un sistema propio de protección de los derechos humanos.

Algunos autores alertan sobre el peligro de conspiración contra una idea universal de derechos humanos, que el desarrollo de sistemas regionales puedan provocar, y señalan como previsión que «... En último análisis, la protección regional debe venir enmarcada en una organización regional de acuerdo con la Carta de las Naciones Unidas.» 130 .

Por cierto, la existencia de sistemas paralelos puede acarrear conflictos, pero solucionables si se respeta el principio «pro homine», que debe regir el marco de protección de los derechos humanos 131 .

Los sistemas internacionales y regionales de derechos humanos se alimentan entre sí, aportando unos a los otros sus propias instituciones y procedimientos; y ofreciendo finalmente a las víctimas, un amplio abanico de protección.

De igual forma, los procedimientos que se encuentran son diferentes, y cabe la posibilidad, que un Estado no se vincule a un instrumento regional, y sí lo haga a uno dentro de Naciones Unidas, o viceversa.

También, las particularidades de cada región pueden dotar a los instrumentos regionales de una riqueza que a nivel internacional es muy difícil de lograr, desde el punto de vista de los derechos protegidos, o de los sujetos titulares de derechos; tal es el ejemplo de los derechos de los pueblos consagrados dentro del sistema africano de derechos humanos, en el marco de la Organización de la Unidad Africana.

El peligro respecto a la adopción de decisiones diferentes sobre un mismo caso está descartado, ya que los instrumentos de derechos humanos consagran expresamente, la imposibilidad de someter un mismo asunto a distintos procedimientos internacionales de derechos humanos.

Claro que, para que exista identidad de caso, deben darse ciertos requisitos en cuanto a los sujetos, el objeto y, finalmente, el tipo de mecanismo utilizado. Esta cuestión ha sido estudiada por el Consejo de Europa, en ocasión de adoptarse la Convención de Minsk de la Comunidad de Estados Independientes; en particular, las implicancias legales y los conflictos que puedan surgir para los Estados, que han ratificado la Convención de Minsk y el Convenio Europeo de Derechos Humanos 132 .

Hitters considera que no hay motivo para observar a los sistemas internacional y regionales como contrapuestos, sino que, por el contrario, deben conjugarse armoniosamente 133 .

En sentido concordante, Gros Espiell menciona, que la opción excluyente entre universalismo y regionalismo en cuanto a la protección de los derechos humanos, debe considerarse descartada; y que actualmente, se consideran como sistemas que deben coexistir para aumentar y hacer más eficaz la promoción y protección internacional de los derechos humanos, eficacia que se acrecienta por la interacción e influencia recíproca 134 .

El sistema de las Naciones Unidas, entonces, coexiste con diferentes sistemas regionales de protección de los derechos humanos: esta coexistencia puede ser calificada como compatible, complementaria y no excluyente, enfocada desde la perspectiva de una más eficaz protección a las víctimas de violaciones a los derechos humanos.

Las características mencionadas se dan porque el sistema internacional y el regional no se descartan, abarcan un mismo abanico de derechos, simultáneamente que se refieren a distintas prerrogativas y tipos de sujetos titulares; pero en consecuencia, forman parte de un mismo esquema destinado a remediar y sancionar violaciones a los derechos elementales de la persona.

Es decir, si consideramos la característica de complementariedad que tiene todo el sistema de protección internacional de derechos humanos, podemos concluir que el sistema nacional, el sistema regional y el sistema internacional, forman parte de la aún incompleta, a nuestro juicio, protección integral de los derechos humanos.

\section{II.- Los sistemas regionales de protección}


Cada Organización Internacional ha debatido la forma y manera de proteger los derechos humanos en su interior 135. La adopción (o falta de adopción) de instrumentos y mecanismos de tutela, se da con las diferentes situaciones sociales y políticas de cada región.

Factores tales como la estabilidad política, el grado de democratización, y la fortaleza e interés que genera la propia organización regional, han influido en la conformación de sistemas más o menos garantistas de los derechos humanos.

Haremos, a continuación, un somero análisis de los principales aspectos de los sistemas regionales de protección.

\section{1.- La Liga de Estados Arabes 136}

La protección de los derechos humanos dentro de la Liga de los Estados Arabes es aún modesta; siendo esta región una de las más carentes en la materia.

El propio texto constitutivo de la Liga (adoptado en 1945) no incluía norma alguna en materia de derechos humanos; la primera acción concreta, la encontramos con la creación de la Comisión Regional Permanente Arabe para los Derechos Humanos, por la Resolución 2443 de 1968. Las funciones iniciales de la Comisión, han sido eminentemente de promoción, ocupándose sólo en su faz protectiva, de las violaciones producidas por Israel en los Territorios Ocupados 137 .

El trabajo destinado a adoptar un convenio de derechos humanos dentro de la Liga de Estados Arabes, ha sido lo suficientemente lento como para arribar, recién en 1994, a la adopción de la Carta Arabe de Derechos Humanos 138 .

La Carta Arabe tiene para destacar, la mención que hace a instrumentos internacionales de derechos humanos en su Preámbulo (comenzando por la Declaración Universal de Derechos Humanos); y que contiene en su seno a derechos civiles, políticos, económicos, sociales y culturales 139 .

La Carta, crea un Comité de Expertos como órgano de aplicación de la misma, el cual está compuesto por siete personas, de reconocida competencia en derechos humanos.

Existen factores que debilitan la protección de los derechos humanos en la Liga de Estados Arabes; entre ellos la conformación política de los Estados (reinos o gobiernos autoritarios), la historia de guerras civiles, los grupos de oposición armada, la declaración continua de estados de emergencia, y la postura política de muchos Estados que han opuesto un importante número de reservas, no siempre compatibles con el objeto y fin, a instrumentos internacionales de derechos humanos 140 (ver página siguiente) .

Las dificultades mencionadas, particularmente la falta de voluntad política, han significado que la Carta Arabe no se encuentre en vigor 141.

\section{2.- El Consejo de Europa}

Cuando mencionamos a la protección de los derechos humanos en el ámbito europeo, debemos diferenciar tres escenarios institucionales diferentes, (que corresponden a la Organización sobre Seguridad y Cooperación Europea, la Unión Europea y el Consejo de Europa). A los efectos del presente Capítulo, sin embargo, sólo interesa el análisis del último de ellos.

El Sistema Europeo de Derechos Humanos, desarrollado dentro del Consejo de Europa, ha sido el primer sistema regional de protección de derechos humanos en ver la luz; probablemente, por haber sido el continente europeo, el lugar donde la Segunda Guerra Mundial produjo los efectos más devastadores en la materia.

La protección de los derechos humanos en el Consejo de Europa, se da en tres instrumentos jurídicos principales: El Convenio Europeo de 4 de noviembre de 1950 y sus protocolos adicionales; la Carta Social Europea de 18 de octubre de 1961, y su Protocolo adicional de 5 de mayo de 1988; y finalmente, el Convenio Europeo para la Prevención de la Tortura y de las Penas o Tratos Inhumanos o Degradantes, del 26 de noviembre de 1987.

De esos tres instrumentos, el más trascendente es el primero de ellos, por al abanico protectivo, y el rol de la víctima o su representante dentro del sistema. 
Frente a los antecedentes de mecanismos de protección de los derechos humanos, el instrumento adoptado en el Consejo de Europa resultó revolucionario. En efecto, tal como sostiene Castro-Rial Garrone, «... El Convenio resulta más innovador que los anteriores intentos internacionales de protección de los Derechos Humanos. En parte, porque no sólo se efectúa una codificación de Derecho Positivo con una enumeración de carácter genérico, como en los acuerdos que le precedieron, sino que desciende, a veces con mucho detalle, a la definición del contenido de los derechos humanos, tal es el caso del art. 5 que salvaguardia uno de los derechos más fundamentales del ser humano como es la libertad y trata de evitar cualquier arbitrariedad del poder público. Enumera exhaustivamente los supuestos legítimos de privación de libertad. Al mismo tiempo, el Convenio salvaguarda y garantiza de modo explícito en su articulado las normas establecidas...» 142 .

Básicamente, el sistema derivado del Convenio de Roma y sus Protocolos, marca la protección de derechos de tipo civil y político, con algunos derechos de tipo económico, social y cultural 143 .

El Convenio Europeo, tuvo como fuente a la Declaración Universal de los Derechos Humanos de 1948, aunque su catálogo de derechos, a pesar del complemento de derechos marcado en algunos protocolos, es más restringido que el de esta última 144 .

Aunque, tal como sostiene Karol Vasak, la gran importancia del Convenio Europeo no radica exactamente en el grupo de derechos protegidos, sino en los mecanismos desarrollados para la protección de los mismos, que serán analizados más adelante 145 .

\section{3.- La Organización de la Unidad Africana 146}

La Organización de la Unidad Africana es una de las entidades intergubernamentales generales más recientes; surgida en la llamada "era de la descolonización", con la idea de acercar a los Estados africanos independientes, dentro del marco de la unidad africana 147 .

El instrumento de derechos humanos más importante del sistema, es la Carta Africana sobre los Derechos Humanos y de los Pueblos, adoptada el 27 de julio de 1981, por la Organización de la Unidad Africana (OUA) reunida en Nairobi (Kenia).

La Carta Africana de Derechos Humanos, contiene derechos fundamentales que se encuentran receptados en otras normas internacionales, adoptadas en el seno de la Organización de las Naciones Unidas; aunque también difiere en ciertos aspectos de los otros sistemas regionales con tratados en vigor, como el europeo y el interamericano 148 .

La Carta Africana, posee algunas características propias, al reflejar el concepto africano de derechos humanos. Subraya, por ejemplo, el derecho a la libre determinación de los pueblos; determina deberes de los individuos respecto a la comunidad y al Estado; y reconoce a las personas, no sólo el derecho a solicitar asilo en caso de persecución, sino de obtenerlo.

La Carta Africana consagra derechos individuales 149 , derechos de los pueblos 150 , deberes de los Estados 151, y deberes de los individuos 152 .

\section{4.- La Comunidad de los Estados Independientes 153}

La desintegración de la Unión Soviética, trajo aparejado el nacimiento de una nueva organización, a la que se le dio por nombre "Comunidad de Estados Independientes". Dentro de la misma, se creó la Convención de Minsk sobre Derechos y Libertades Fundamentales del Hombre.

Esta Convención, considera los instrumentos internacionales universales más importantes, (nos referimos a la Declaración Universal de Derechos Humanos y los Pactos Internacionales de Derechos Civiles y Políticos; y Económicos, Sociales y Culturales). También, toma a los acuerdos celebrados en el marco de la Organización para la Seguridad y Cooperación Europea.

La Convención de Minsk, es un tratado que consagra derechos civiles y políticos básicos, como la vida o la interdicción de la tortura, las garantías judiciales y procesales elementales, la prohibición de la esclavitud y de los trabajos forzados; contempla el derecho a voto, secreto y obligatorio; y la prerrogativa para los ciudadanos, de formar parte del gobierno, gestión y dirección de los asuntos de su Estado 154 . 


\section{5.- La Organización de los Estados Americanos}

Esta entidad nace en 1948, en la IX Conferencia Internacional Americana que se celebró en la ciudad de Bogotá, Colombia. La estructura jurídico institucional de la misma, era endeble en los inicios; por ende, se ha ido reforzando con el paso del tiempo, a través de la creación de órganos, y la modificación propiamente dicha de la Carta en diferentes oportunidades. La reforma adoptada en Buenos Aires, en el año 1967, fue tildada de «estructural», por la profundidad de los cambios introducidos en la organización y funcionamiento de la entidad 155 .

El sistema interamericano toma como concepción de los derechos humanos, el hecho de que éstos tienen como fundamento los atributos de la persona humana; adhiriendo a la idea de los derechos humanos, como «inherentes a la persona por el hecho de ser tal» 156 .

Esta concepción, ha sido reforzada por la jurisprudencia de la Corte Interamericana de Derechos Humanos, en varios casos contenciosos resueltos: así, dicho Tribunal sostuvo que «... está más allá de toda duda que el Estado tiene el derecho y el deber de garantizar su propia seguridad. Tampoco puede discutirse que toda sociedad padece por las infracciones a su orden jurídico. Pero, por graves que puedan ser ciertas acciones y por culpables que puedan ser los reos de determinados delitos, no cabe admitir que el poder pueda ejercerse sin límite alguno o que el Estado pueda valerse de cualquier procedimiento para alcanzar sus objetivos, sin sujeción al derecho o a la moral. Ninguna actividad del Estado puede fundarse sobre el desprecio a la dignidad humana...» 157 .

Los instrumentos jurídicos más importantes del sistema, son la Declaración Americana de Derechos y Deberes del Hombre 158 ; la Convención Americana sobre Derechos Humanos 159 , y sus dos Protocolos Anexos 160 ; la Convención Interamericana para Prevenir y Sancionar la Tortura 161 ; la Convención Interamericana sobre Desaparición Forzada de Personas 162 (ver página siguiente) ; y la Convención Interamericana para prevenir, sancionar y erradicar la violencia contra la Mujer 163 (ver página siguiente) .

La Convención Americana sobre Derechos Humanos, o Pacto de San José de Costa Rica, es un típico instrumento de derechos civiles y políticos. Posee algunas similitudes con el Convenio Europeo para la Protección de los Derechos y Libertades Fundamentales del Consejo de Europa, el cual le ha servido como inspiración, junto al Pacto Internacional de Derechos Civiles y Políticos de las Naciones Unidas 164.

Entre sus previsiones más importantes, encontramos la protección del derecho al reconocimiento de la personalidad jurídica; a la vida; a la integridad corporal; la prohibición de la esclavitud o servidumbre; el derecho a la libertad personal; las garantías judiciales; los principios de legalidad y de retroactividad; el derecho a una indemnización en caso de haber sido condenado por error judicial; la protección de la honra y la dignidad; la libertad de conciencia y de religión; la libertad de pensamiento y de expresión; el derecho a réplica; el derecho de reunión; la libertad de asociación; la protección a la familia; el derecho al nombre; los derechos del niño; el derecho a la nacionalidad; el derecho a la propiedad; los derechos de circulación y residencia; los derechos políticos; la igualdad ante la ley; y la protección judicial.

La Convención Americana, define como persona a «todo ser humano»; en los artículos 1 y 2 se determina la obligación para los Estados, de respetar los derechos y garantizar su ejercicio a todas las personas sin discriminación, así como de adoptar todas las medidas de derecho interno, para hacer efectivos los derechos reconocidos.

El primero de los artículos del Pacto de San José de Costa Rica, ha sido la fuente en la que abrevó la Corte Interamericana de Derechos Humanos para elaborar toda su jurisprudencia en relación a las obligaciones de los Estados de cara a la Convención, tal como hemos visto anteriormente, y se desarrollará en el análisis particular de las decisiones tomadas por el Tribunal (Capítulos IV, VI, VII y VIII).

En materia de derechos económicos y sociales, sólo un artículo del Pacto de San José compromete a los Estados para que adopten providencias para un desarrollo progresivo de los derechos económicos, sociales y culturales, por medio de la legislación interna, la cooperación internacional y en la medida que los recursos disponibles lo permitan. El desarrollo de los derechos 
económicos, sociales y culturales en el sistema interamericano, cuenta con el Protocolo de San Salvador, al que ya hemos mencionado 165 (ver página siguiente) .

La adopción y entrada en vigor de la Convención Americana es, según Claudio Grossmann, el paso más trascendental que han dado las naciones del hemisferio para establecer obligaciones jurídicas en el ámbito de los derechos humanos 166 .

\section{III.- Los mecanismos de protección de los derechos humanos}

La evolución normativa de los diferentes instrumentos de derechos humanos, en las instituciones internacionales, ha sido acompañada por el desarrollo de órganos y mecanismos de protección, para vigilar el grado de cumplimiento de los Estados, respecto de aquellas obligaciones asumidas en la materia.

Sí puede señalarse que, generalmente, existe una primera etapa de consagración normativa de derechos humanos, y una segunda etapa de creación de medios para hacer efectivos a aquellos.

También es dable mencionar, que los derechos civiles y políticos gozan hoy de mecanismos de protección más eficaces que los derechos económicos, sociales y culturales, y que los derechos de los pueblos.

En los mecanismos de protección que existen hoy a nivel internacional, hay una preeminencia de instituciones administrativas por sobre las de tipo judicial; en buena medida, debido a la renuencia de muchos gobiernos, a la adopción de normas, que les puedan colocar en la posición de acusados en un juicio por violaciones a los derechos humanos.

Así, todos los sistemas conocidos (dentro de Naciones Unidas, el Consejo de Europa, la Organización de los Estados Americanos, la Liga de Estados Arabes, la Organización de la Unidad Africana y la Comunidad de Estados Independientes), poseen órganos administrativos o cuasi jurisdiccionales, llamados «comité»o «comisión».

No sucede lo mismo con los órganos judiciales, debido a que sólo hay hasta el momento, dos tribunales propiamente dichos de derechos humanos, y ambos a nivel regional: la Corte Interamericana de Derechos Humanos y el Tribunal Europeo de Derechos Humanos 167 (ver página siguiente).

Asimismo, el mecanismo más generalizado es el llamado «procedimiento de informes», el menos inquisitivo de los métodos que existen, para proteger los derechos humanos.

Finalmente, los requisitos para que un Estado sea llevado ante un procedimiento judicial, son mucho más exigentes que para el resto de los procedimientos.

Siguiendo la clasificación esbozada por Villán Duran, dividimos a los mecanismos de protección en convencionales y extraconvencionales; y a su vez a los primeros en no contenciosos, cuasicontenciosos y contenciosos 168 .

Esta clasificación, hecha por el autor al sólo efecto de desarrollar los mecanismos que se encuentran en el seno de las Naciones Unidas, sus instrumentos e instituciones especializadas; puede aplicarse a las organizaciones regionales, aunque el sistema interamericano, ha impulsado el recurso individual a partir del Estatuto y Reglamento de la Comisión Interamericana de Derechos Humanos, como analizaremos más adelante.

\section{1.- La protección convencional}

La protección de derechos humanos conocida como convencional, es aquella que se encuentra estipulada en pactos o convenciones.

Casi todos los instrumentos convencionales de derechos humanos, tanto a nivel internacional como regional, poseen mecanismos de protección en su seno, siendo una excepción a esta regla la Convención Interamericana para Prevenir y Sancionar la Tortura, aprobada dentro de la Organización de los Estados Americanos.

El sistema más común que puede encontrarse en los instrumentos convencionales, es el llamado «procedimiento de informes», aunque es una característica que procede más en los pactos generales o particulares que se adoptan en Naciones Unidas, que en las organizaciones regionales. 
De acuerdo a la clasificación que seguimos, analizaremos a continuación los tres tipos de mecanismos que nos ofrece la protección convencional de los derechos humanos.

a) Mecanismos no contenciosos

El profesor Carlos Villán Durán, sostiene que los mecanismos no contenciosos (información y conciliación), son los procedimientos más antiguos establecidos; y que por ende, los que más se parecen al tipo de soluciones que ofrece el Derecho Internacional clásico, para arreglar controversias entre Estados. No son mecanismos contenciosos ni contradictorios, y encuentran su fundamento en la cooperación internacional entre Estados Soberanos 169 .

El sistema de informes, consiste en la presentación, por parte de un Estado que ha ratificado un tratado de derechos humanos que prevé este mecanismo, de informaciones acerca del estado de los derechos protegidos en dicho pacto.

Estas presentaciones se hacen, o bien periódicamente, o bien cuando los órganos encargados de supervisar los informes lo soliciten, dependiendo esto de la normativa convencional que regula el funcionamiento del procedimiento.

El sistema de informes se encuentra dentro de Naciones Unidas en los dos pactos internacionales generales (Pacto Internacional de Derechos Civiles y Políticos 170 , y Pacto Internacional de Derechos Económicos, Sociales y Culturales 171 ); y en algunos convenios específicos: la Convención Internacional sobre la Eliminación de todas las Formas de Discriminación Racial 172 , la Convención Internacional sobre la Eliminación de todas las Formas de Discriminación contra la Mujer 173 , la Convención Internacional sobre la Represión y el Castigo del Crimen del Apartheid 174 , la Convención contra la Tortura y Otros Tratos o Penas Crueles, Inhumanos o Degradantes 175 , la Convención Internacional contra el Apartheid en los Deportes 176 , la Convención sobre los Derechos del Niño 177 , y la Convención Internacional sobre la protección de todos los trabajadores migratorios y sus familias 178 .

Cada una de estas convenciones y pactos, ha creado un órgano propio, con el fin de supervisar el cumplimiento del instrumento, por parte de los Estados que se hayan vinculado jurídicamente a ellas. La excepción, está dada por el Pacto Internacional de Derechos Económicos, Sociales y Culturales, cuyo órgano de supervisión es el Comité de Derechos Económicos, Sociales y Culturales, creado por el Consejo Económico y Social de las Naciones Unidas 179 .

A nivel regional, en los instrumentos troncales de protección de los derechos humanos que poseen las instituciones internacionales, el sistema de informes está establecido en la Carta Arabe de Derechos Humanos 180 .

La Carta Africana de Derechos Humanos y de los Pueblos, establece una obligación para los Estados partes, de presentar informes sobre las medidas legislativas o de otro carácter, que se hayan adoptado para hacer efectivos los derechos establecidos. Aunque no se establece ante quien deben presentarse esos informes, la Carta ha creado la Comisión Africana de Derechos Humanos y de los Pueblos, como órgano encargado de supervisar el cumplimiento de la Carta. Es dable suponer, entonces, que la Comisión es la habilitada para recibir y analizar estos informes 181 .

Respecto a los otros instrumentos regionales que hemos considerado en el capítulo anterior (la Convención Americana sobre Derechos Humanos, el Convenio Europeo para la Protección y Salvaguarda de los Derechos y Libertades Fundamentales, y la Convención de Minsk de la Comunidad de los Estados Independientes), el mecanismo de informes, tal y como ha sido descrito aquí, no se encuentra previsto.

Los procedimientos de conciliación (buenos oficios y contactos directos), son más de tipo «sui generis»; y consiste en la realización de gestiones oficiosas, basadas en razones estrictamente humanitarias, por parte de secretarios generales de Organizaciones Internacionales, o representantes de órganos de derechos humanos.

b) Mecanismos cuasicontenciosos

Según Villán Duran, este procedimiento procede, a diferencia del anterior, frente a alguna violación de un derecho consagrado en las convenciones que lo prevén; y tiene como fin, conseguir algún tipo de resarcimiento por la violación producida 182 . 
El tipo de mecanismo (contradictorio) lo asemeja a un juicio, ya que el Estado acusado recibe una queja, y debe contestarla, se produce prueba $\mathrm{y}$, finalmente, el órgano supervisor toma una determinación.

En general, las resoluciones de los órganos contienen una evaluación de si ha habido violación del derecho que se trate $\mathrm{y}$, en caso afirmativo, se propone una forma de reparación. La forma asumida, es a través de «recomendaciones» a los Estados.

El perfil que pueden revestir estos mecanismos cuasicontenciosos son tres: quejas entre Estados, quejas de un órgano internacional contra un Estado, y quejas de un individuo contra un Estado.

Este procedimiento se encuentra consagrado en diferentes instrumentos internacionales, tanto dentro de las Naciones Unidas, como de organizaciones regionales.

A nivel de la entidad nacida en San Francisco, la Convención para la Eliminación de todas las formas de Discriminación Racial, el Pacto Internacional de Derechos Civiles y Políticos, la Convención contra la Tortura y otros Tratos o Penas Crueles, Inhumanos o Degradantes, y la Convención Internacional sobre la Protección de los Derechos de Todos los Trabajadores Migratorios y sus Familias, dan la posibilidad de que un Estado Parte presente una comunicación contra otro Estado Parte 183 .

En los ámbitos regionales, el Convenio Europeo de Salvaguardia de los Derechos Humanos y Libertades Fundamentales (o Convenio Europeo de Derechos Humanos), establece para todos los Estados Partes del mismo, la jurisdicción obligatoria de la Comisión Europea de Derechos Humanos, para recibir denuncias de un Estado Parte contra otro 184 .

El sistema interamericano de derechos humanos, también prevé este mecanismo de Estado contra Estado; aunque, a diferencia del europeo, es facultativo, por el cual los Estados Partes, tienen la posibilidad de declarar en un acto diferente al de ratificación (aunque puede ser simultáneo), que reconocen la competencia de la Comisión Interamericana para recibir y examinar las comunicaciones, en las que otro Estado parte, alegue que aquel ha violado alguno de los derechos establecidos en el Pacto de San José de Costa Rica, bajo condición de reciprocidad 185 .

El sistema africano, da una doble posibilidad de reclamaciones interestatales; una frente al Secretario General de la Organización de la Unidad Africana y el Presidente de la Comisión Africana de Derechos Humanos y de los Pueblos; y otra directamente frente a la propia Comisión Africana. Ambas se encuentran reguladas en la Carta Africana de Derechos Humanos y de los Pueblos 186 .

La Carta Arabe de Derechos Humanos, no posee la posibilidad de reclamación interestatal; y en el sistema instaurado por la Comunidad de Estados Independientes, tampoco se prevé este mecanismo.

El sistema de reclamación interestatal, no se ha puesto en funcionamiento en Naciones Unidas; ni tampoco se conocen casos de Estado contra Estado, dentro de los sistemas interamericano y africano de derechos humanos.

En el ámbito que sí se conocen demandas interestatales, es en el Consejo de Europa, donde se han recibido y resuelto casos. Aunque nunca tiene la reclamación interestatal, la magnitud que posee la petición individual 187 .

Las reclamaciones de particulares contra un Estado, tienen una doble significación dentro del Derecho Internacional Contemporáneo: por un lado, dan la posibilidad efectiva para la comunidad internacional, de tutelar una violación individual de derechos humanos, que ha sido producida por un gobierno, en perjuicio de una persona; por el otro, da firmeza a la posición de subjetividad jurídico internacional del individuo, en el Derecho Internacional Público.

En el ámbito de Naciones Unidas, el Comité sobre la eliminación de todas las formas de Discriminación Racial, puede recibir y examinar comunicaciones de personas, o grupos de personas, respecto de una violación de la Convención producida por un Estado Parte. Uno de los requisitos de admisibilidad, consiste en que quien denuncia, debe reputar la calidad de víctima directa o indirecta, de la violación alegada. Las reclamaciones, se tramitan ante el Comité para la Eliminación de la Discriminación Racial. 
De igual forma, la Convención contra la Tortura y otros Tratos o Penas Crueles, Inhumanos o Degradantes, establece un mecanismo similar frente al Comité contra la Tortura.

También, el Primer Protocolo Facultativo anexo al Pacto Internacional de Derechos Civiles y Políticos, le otorga facultad al Comité de Derechos Humanos, para recibir comunicaciones individuales.

Por último, la Convención Internacional sobre la Protección de los Derechos de Todos los Trabajadores Migratorios y de sus Familiares, también acepta la comunicación individual, ante el Comité de Protección de los Derechos de Todos los Trabajadores Migratorios y de sus Familiares.

Estos cuatro instrumentos exigen la aceptación expresa de la posibilidad de ser denunciado por parte del Estado, ya sea a través de una declaración de aceptación de competencia (los tres primeros instrumentos), o de la ratificación del Primer Protocolo Facultativo (en el caso del Pacto Internacional de Derechos Civiles y Políticos).

A nivel regional, el sistema europeo establecido en el Convenio de Roma, da la oportunidad al individuo de acudir en reclamaciones individuales a la Comisión Europea de Derechos Humanos 188 .

Es importante detenerse en el mecanismo instaurado por el Convenio de Roma, debido particularmente a la evolución que ha sufrido - y sufre actualmente - el sistema, que también requiere la calidad de víctima del reclamante.

Aunque, al igual que los casos examinados de Naciones Unidas, esta competencia es facultativa, en los hechos puede hablarse de un "sistema obligatorio de facto" para las reclamaciones individuales, ya que para formar parte del Consejo de Europa, por una norma no escrita, todos los Estados deben ratificar el Convenio Europeo, y realizar la declaración prevista en su artículo 25.

Pero además, ha existido un avance notorio. Esta ampliación espectacular, se debe de la capacidad del individuo de presentarse por sí, frente a un órgano jurisdiccional internacional: el Tribunal Europeo de Derechos Humanos. Además, a fines de 1998, cuando entre en vigor el Protocolo XI, se eliminará la Comisión Europea, y el individuo acudirá directamente ante el tribunal Europeo, que será redimensionado en su composición y funciones.

En el sistema africano de Derechos Humanos, la Carta Africana, autoriza a la Comisión Africana de Derechos Humanos y de los Pueblos a recibir denuncias. Aunque si bien las denuncias pueden emanar de un individuo (aún sin revestir este último la calidad de víctima), cualquier organización no gubernamental u otra entidad; dichas comunicaciones únicamente pueden referirse a violaciones masivas; esto es, no se busca ofrecer remedio a violaciones aisladas, o a asuntos particulares, como en el caso europeo analizado recién 189 .

Puede afirmarse, que la protección del individuo queda un tanto desdibujada en el seno del sistema africano, de forma tal que «el mecanismo previsto por la Carta para tratar las comunicaciones individuales se parece mucho al procedimiento establecido en el marco de las Naciones Unidas en virtud de la Resolución 1503 del Consejo Económico y Social» 190 .

Degni - Segui, habla del «Talón de Aquiles» que sufre el sistema africano de derechos humanos; refiriéndose a la debilidad del mecanismo de protección, y en definitiva, la frágil salvaguarda de los derechos humanos, para las víctimas de violaciones a los mismos 191 .

Dentro de la Liga de Estados Arabes, la Carta Arabe de Derechos Humanos, no contempla el recurso de petición individual frente al Comité de Expertos; contemplándose tan sólo, el mecanismo de informes que ya hemos analizado en este Capítulo.

Respecto al ámbito de la Comunidad de los Estados Independientes, si bien la letra de la Convención de Minsk no detalla los procedimientos para la protección de los derechos contenidas en ella, establece que el Estatuto de funcionamiento de la Comisión de Derechos Humanos de la Comunidad de los Estados Independientes, se considera comprendido en el texto del tratado 192 . En este Estatuto, se le otorga a los individuos y a las organizaciones no gubernamentales, la posibilidad de realizar aplicaciones individuales ante dicha Comisión 193 .

En cuanto al sistema interamericano, hemos mencionado anteriormente que el mismo ha desarrollado el recurso individual, a partir del Estatuto y Reglamento de la Comisión Interamericana de Derechos Humanos. 
Es decir, dicho mecanismo no nace de una convención, sino de los instrumentos que dan composición y funcionamiento, a la Comisión Interamericana sobre Derechos Humanos.

De todas formas, a nivel indirecto podría considerarse dentro de la protección convencional; debido a que se trata de la tutela de los derechos humanos, que se encuentran contenidos en la Carta de la Organización de los Estados Americanos - cuyo desarrollo se halla en la Declaración Americana de Derechos y Deberes del Hombre -; y de los derechos contenidos en la Convención Americana sobre Derechos Humanos (o Pacto de San José).

Algunos autores, hablan de una doble base protectiva, convencional y extraconvencional, que operan dentro del sistema interamericano de protección. El hecho de que ciertos procedimientos no encuentran su nacimiento en una Convención, no debe ser motivo de menosprecio. Es más, poseen el mérito de vincular a todos los Estados miembros de la Organización, y tienen un grado de utilización importante: «... el sistema previsto en el Pacto de San José no constituye el único mecanismo de protección de los derechos humanos existente en el sistema interamericano, ni siquiera el utilizado con mayor frecuencia. Por el contrario, ya con anterioridad a la entrada en vigor de la Convención de 1969, la Comisión Interamericana había recibido importantes competencias protectoras cuyo ejercicio se encontraba regulado en su Estatuto y que se han mantenido con posterioridad a la entrada en vigor de aquella, en 1978...» 194 .

El mecanismo establecido para casos individuales, dentro del sistema interamericano, enseña como peculiaridad inicial la amplitud de acceso a la Comisión Interamericana de Derechos Humanos, órgano principal de la Organización de los Estados Americanos.

Si realizamos un análisis desde la perspectiva de la posibilidad de acceso (legitimación activa); cualquier persona, grupo de personas o entidad no gubernamental legalmente reconocida en uno o más estados miembros de la OEA, puede peticionar a la Comisión Interamericana, con denuncias o quejas de violaciones a alguno de los derechos, protegidos en la Declaración Americana de Derechos y Deberes del Hombre, o en la Convención Americana; incluso, si posee información que a su juicio sea idónea, la Comisión puede iniciar un caso de oficio 195 .

Conforme a lo analizado ya en el presente Capítulo, podemos subrayar en cuanto a la legitimación activa, una distinción radical entre el sistema interamericano y el sistema europeo, ya que en éste último se requiere la condición de víctima de quien formule la petición. Dicho requisito, es uno de los más estrictos, según la práctica de la Comisión Europea de Derechos Humanos 196.

Existen algunas exigencias para la presentación de la comunicación: la identificación de quien o quiénes denuncian con sus datos particulares; un relato de los hechos denunciados consignando fecha y lugar; si es posible, el nombre o nombres de las víctimas y la autoridad pública que haya tomado conocimiento del hecho; la indicación clara del Estado al que se considera responsable; y por último, un informe acerca de si para la tramitación del caso, se han hecho uso o no de los recursos de jurisdicción interna, o si ha existido imposibilidad de algún tipo, para dar cumplimiento a este último requisito 197 .

Además, en el sistema interamericano, la presentación de la comunicación debe realizarse en un plazo no mayor de seis meses de la notificación de la última resolución interna, o, si los recursos internos no han podido agotarse, en un plazo razonable, a criterio de la Comisión, a partir de la fecha en que haya ocurrido la presunta violación de los derechos, considerando las circunstancias concretas de cada caso en particular 198 .

Asimismo, será declarada inadmisible toda comunicación que sea, substancialmente, la reproducción de una petición o comunicación anterior, que ya haya sido examinada por la Comisión u otro organismo internacional 199 .

En relación a esta última situación, Luis Jimena Quesada manifiesta que para comprender esta previsión, debe mirársela en conjunto con el artículo treinta y nueve del reglamento de la Comisión, debido a que si del examen no se coincide en el objeto, aunque se trate de una misma situación, o si los sujetos del caso no son los mismos, la Comisión no hará lugar a la excepción del «non bis in idem» 200 .

El requisito del agotamiento de los recursos internos, ha sido objeto de tratamiento, tanto por la Comisión, como por la Corte Interamericana 201. 
Así, la Comisión Interamericana de Derechos Humanos, manifestó que cuando existe una práctica de desapariciones, el hecho de haber intentado un hábeas corpus o un amparo sin la obtención de un resultado satisfactorio, (o sea la aparición de la persona); debe ser considerado como suficiente, para considerar agotados los recursos internos 202 .

En cuanto a la Corte Interamericana, el desarrollo de su faz consultiva (que se analizará más adelante), ha derivado en opiniones de dicho Tribunal, las cuáles mencionan que no debe exigirse el agotamiento de los recursos internos, si un particular no ha podido cumplir este requisito, por razones de indigencia económica, o por causa de temor generalizado de los círculos jurídicos de su país, en representarlo judicialmente 203 .

También en su faz contenciosa, la Corte Interamericana ha abarcado esta cuestión; así, en los llamados «casos hondureños» sostuvo que si hay pruebas de que, a pesar de existir mecanismos jurídicos dentro de un Estado, aquellos son meramente formales, no puede un gobierno argumentar el no agotamiento de los recursos internos, si el peticionante no ha acudido a los mismos 204 .

Asimismo, el propio reglamento de la Comisión Interamericana contiene disposiciones al respecto: no se exige el requisito de agotamiento de los recursos internos, si estos no existen, o si al lesionado se le ha impedido acceder o agotarlos, o si, finalmente, hay un retardo injustificado para resolverlos 205 .

De las dos aseveraciones anteriores, podemos concluir que para que prospere una excepción gubernamental, basada en el no cumplimiento de la regla por parte del denunciante, es necesario que los recursos internos existan, que sean eficaces para reparar la violación alegada, y que el peticionante, haya tenido acceso libre a los mismos, y a la posibilidad de darles trámite.

Es interesante la previsión, que obliga a llevar la carga de la prueba a la representación del Estado, cuando el peticionario alegue no poder probar que ha agotado los recursos internos. En efecto; en ese caso, es el gobierno quien debe probar el no agotamiento 206 .

Es posible que un caso individual que se lleve ante la Comisión Interamericana, finalice con una solución amistosa que la Comisión puede proponer por sí, o a pedido de alguna de las partes 207 .

De tal forma, la potestad de la Comisión respecto a la proposición de una solución amistosa es facultativa, si bien sujeta a ciertas pautas.

Mónica Pinto, analizando la práctica de la Comisión menciona algunos criterios que tuvo la misma, para declarar improcedente la aplicación de la solución amistosa. Así, la autora indica como ejemplos, la ausencia de respuesta de un gobierno a las preguntas de la Comisión, que naturalmente conlleva falta de interés en una solución amistosa; o cuando el motivo de la queja radica en una cuestión eminentemente jurídica; cuando el Estado denunciado ha cuestionado la competencia de la Comisión para entender en la denuncia; o cuando hay desaparición forzada, por la propia naturaleza del asunto 208 .

Si se ha logrado una solución amistosa, la Comisión redacta un informe con una breve descripción del caso y el texto del acuerdo arribado.

Si la solución amistosa ha fracasado, o no ha sido propuesta, la Comisión Interamericana de Derechos Humanos debe confeccionar un informe confidencial con las recomendaciones que crea pertinentes, el cual es puesto a consideración del Estado.

El Estado tiene tres meses para cumplir con las recomendaciones formuladas. Pasado el plazo, la Comisión analiza si el estado ha cumplido con lo solicitado, y decide si publica o no el informe, por el voto de la mayoría absoluta de sus miembros 209 .

c) Mecanismos contenciosos

Los mecanismos contenciosos propiamente dichos, se llevan adelante ante órganos jurisdiccionales de derechos humanos, que estén dotados de competencia, para juzgar violaciones a los mismos.

Como sujetos pasivos de dicha acción, se encuentran principalmente los Estados; aunque se está ampliando la legitimación pasiva progresivamente a los individuos, a través de las instancias jurisdiccionales ad hoc creadas en la Organización de las Naciones Unidas, y el proyecto de creación de una Corte Penal Internacional con carácter permanente 210 . 
Carlos Villán Duran sostiene que por medio del arreglo judicial «... se determina la existencia de una violación y se precisa el contenido de la responsabilidad del Estado en casos que no han podido ser dirimidos a través del sistema universal de peticiones. Además, el arreglo judicial permite la tutela más estricta de los derechos lesionados y la consecución de medidas de reparación que, una vez dictadas por el tribunal competente, serán de obligado cumplimiento por parte del Estado responsable de la violación...» 211 .

En la Organización de las Naciones Unidas existe un órgano judicial, la Corte Internacional de Justicia, que no es stricto sensu, un tribunal de derechos humanos de acuerdo a su Estatuto.

No obstante, la Corte Internacional de Justicia posee ciertas competencias en materia de derechos humanos, derivadas de normas convencionales que le dan atribución de dirimir controversias entre Estados, en cuanto a la interpretación o aplicación de las disposiciones protectoras que se encuentran en dichos tratados 212 .

De todas formas, cabe concluir que la Corte Internacional de Justicia, a pesar de sus casos resueltos en jurisdicción contenciosa, y en opiniones consultivas donde el tribunal ha interpretado normas de derechos humanos, o hecho consideraciones respecto al caso, en las cuales se señalan ciertos actos como violatorios de los derechos humanos 213 , es evidente que no funciona como los tribunales de derechos humanos propiamente dichos que existen al día de hoy en dos sistemas regionales: la Organización de los Estados Americanos y el Consejo de Europa.

A nivel regional, en la Liga de Estados Arabes, la Comunidad de Estados Independientes y la Organización de la Unidad Africana, no encontramos mecanismos jurisdiccionales de derechos humanos; y por ende, no existen tribunales con competencias al respecto 214 .

Pero en el Consejo de Europa, la Convención Europea de Derechos Humanos, ha creado el Tribunal Europeo de Derechos Humanos 215 . Dicho órgano es tildado por algunos autores como el de máximo nivel, del sistema creado en Roma 216 .

La ampliación del ámbito de actuación del individuo dentro del sistema europeo ha sido espectacular, ya que éste puede acudir bajo ciertos requisitos, como veremos, al Tribunal Europeo de Derechos Humanos; cuando antiguamente, sólo la Comisión y los Estados podían llevar un caso ante dicho órgano.

Efectivamente, esto se ha dado a partir de la adopción del Protocolo Noveno anexo al Convenio Europeo de Derechos Humanos 217 . Este instrumento consagra un derecho para acudir ante el Tribunal de Estrasburgo, en favor de toda persona física, organización no gubernamental o todo grupo de particulares que se considere víctima de una violación de los derechos reconocidos en el Convenio o sus Protocolos; supone, por lo tanto, una prolongación de las demandas individuales previstas en el art. 25 del Convenio Europeo de Derechos Humanos.

Sin embargo, el acceso al Tribunal Europeo para las víctimas no es directo, ya que es necesaria la declaración de admisibilidad del caso, por parte de la Comisión Europea de Derechos Humanos 218 .

Destaca el profesor Flauss que, «... La apertura a la firma de este nuevo Protocolo constituye sin duda un acontecimiento de un gran alcance simbólico. El Tribunal Europeo se convierte en la única Corte Internacional ante la cual los individuos dispondrán de un 'droit d' action en justice' que les autorice a acusar a un Estado y, a la postre, a su propio Estado Nacional...» 219 .

Es importante finalmente, mencionar la adopción en el Consejo de Europa, del Protocolo Once Anexo al Convenio Europeo. Este protocolo, modifica toda la estructura actual de protección de los derechos contemplados en el Convenio de Roma, al proponer la creación de un Tribunal único que tendrá carácter permanente, y que sustituirá a las instituciones de control existentes 220 .

Sánchez Legido sostiene que el nuevo mecanismo diseñado por el protocolo once «... supone un gran avance respecto del sistema vigente en tanto y en cuanto permite salvaguardar y preservar hacia el futuro sus logros más importantes...» 221 .

La jurisprudencia desarrollada por el Tribunal de Estrasburgo, ha sido prolífica y muy importante, ya que no sólo ha resuelto casos, determinado responsabilidades para los gobiernos y establecido indemnizaciones, sino que también ha posibilitado a otros órganos de protección, de 
carácter administrativo o jurisdiccional, de otras Organizaciones Internacionales, tomar sus interpretaciones sobre el contenido de algunos derechos humanos y el alcance de los mismos 222 .

El sistema interamericano, posee también un tribunal de derechos humanos: la Corte Interamericana de Derechos Humanos. El análisis de su competencia y funcionamiento, forma parte del capítulo siguiente del presente libro.

\section{2.- La protección extraconvencional}

Puede considerarse como la protección extraconvencional de los derechos humanos, a aquella que tiene su origen directo no en un tratado, sino como consecuencia del propio desarrollo institucional interno de la Organización Internacional, y que ha derivado de la necesidad de brindar una respuesta a determinadas situaciones claramente lesivas de los derechos humanos, frente a las cuáles las convenciones eran insatisfactorias, bien por defecto en el contenido de las mismas, bien por la falta de ratificación de los Estados.

Jean Luc Mathieu, al analizar la protección extraconvencional menciona que «... se trata de procedimientos desarrollados en el seno de las Naciones Unidas, potencialmente contra todos sus Estados miembros, independientemente de toda Convención particular de protección de los derechos humanos, sobre la base de la Carta de la ONU y la Declaración Universal de los Derechos Humanos, que son consideradas como vinculantes para todo Estados miembro de las Naciones Unidas...» (traducción no oficial) 223 .

Así, dentro de la Organización de las Naciones Unidas, el Consejo Económico y Social ha aprobado una normativa, que cubre el monitoreo del estado de los derechos humanos, frente a una situación de violación masiva y flagrante dentro de un país; o abarca el estudio de un determinado fenómeno violatorio de los derechos humanos, que puede encontrarse en más de un país, y que por su gravedad, merece la atención de las Naciones Unidas.

Los mecanismos extraconvencionales se llevan adelante frente a la Comisión de Derechos Humanos (aunque también interviene la Subcomisión de Derechos Humanos previamente), y ambos tienen como característica común, de acuerdo a Concepción Escobar Hernández, que «... el control del respeto estatal de sus obligaciones se refiere a una situación que parezca revelar un cuadro persistente de violaciones graves y manifiestas de derechos humanos y libertades fundamentales, lo que excluye el tratamiento individualizado de una concreta violación...» 224 .

Los dos mecanismos extraconvencionales, son conocidos por el número de la resolución correspondiente que les ha dado origen: el procedimiento 1503, ha sido creado para examinar las comunicaciones relativas, a las violaciones a los derechos humanos y las libertades fundamentales, en aquellos Estados, en los que se revele una situación persistente de violaciones manifiestas 225 .

El procedimiento 1235, consiste en la creación de órganos especiales (que pueden ser pluripersonales - grupos de trabajo - o unipersonales - relatores especiales -), que examinan la situación de los derechos humanos en un determinado país, o bien un «tema» de derechos humanos y su desarrollo en todo el mundo (pongamos como ejemplo la tortura o las ejecuciones extrajudiciales) 226 .

Las diferencias principales entre ambos mecanismos, están dadas por la confidencialidad que caracteriza al procedimiento 1503, la cual se contrapone al carácter público del procedimiento 1235; y que el primero, exige el agotamiento de los recursos internos, requisito que no es necesario en el segundo.

\section{3.- Los órganos de protección}

Los derechos consagrados dentro de los instrumentos de protección, requieren de instituciones para su tutela y vigilancia. Así, tanto dentro de la Organización de las Naciones Unidas, como dentro de las instituciones regionales, existen diferentes tipos de órganos protectivos de los derechos humanos.

El Derecho Internacional clásico, al ser un derecho de coordinación entre Estados soberanos, da espacio a la creación de entidades internacionales de tipo administrativas, las cuáles se integran por representantes de los gobiernos. 
El Derecho Internacional Contemporáneo, y particularmente en materia de protección de los derechos humanos, da lugar a la creación de órganos de tipo cuasi judicial, o directamente jurisdiccionales, con representantes de las propias instituciones, y sin que estos se hallen subordinados a los gobiernos que les nombran.

Existe un gran número de órganos, que poseen facultades de derechos humanos, las cuáles se hallan compartidas con otras competencias; sírvanos como ejemplo, mencionar a las asambleas generales de la Organización de las Naciones Unidas, y de la Organización de Estados Americanos.

Hay también otros órganos cuyas competencias están de manera específica, dirigidas a temas de derechos humanos; es en estos últimos, en los que queremos hacer hincapié.

Realizamos, dentro del espectro protectivo mundial y regional de los derechos humanos, una clasificación en órganos de tipo administrativo, y de tipo jurisdiccionales.

a) órganos de tipo administrativos

Los órganos de protección de los derechos humanos son, en su mayoría, de tipo no jurisdiccional; aunque algunos de ellos, como el Comité de Derechos Humanos de las Naciones Unidas, tienen funciones cuasi contenciosas, en determinadas actuaciones.

Dentro de la Organización de las Naciones Unidas, el primer órgano instituido para la protección de los derechos y libertades fundamentales de la persona, es la Comisión de Derechos Humanos. Ella, está compuesta por representantes de los Estados, es decir, se trata de una entidad política.

El desarrollo posterior, producido dentro de la Organización de San Francisco, ha mantenido el criterio de que los componentes de los órganos (ya sea de la Subcomisión de Derechos Humanos, del Comité de Derechos Económicos, Sociales y Culturales, y de los creados en virtud de pactos y convenciones), sean expertos en la materia, de gran competencia e idoneidad moral, y que actúen a título individual y no como representantes de ningún gobierno.

El mismo criterio expresado, es el que guía el nombramiento de los relatores especiales y de los miembros que componen los grupos de trabajo, que se crean en virtud del procedimiento 1235 que venimos de analizar.

De igual forma, en Naciones Unidas se sigue idéntica ponderación, en el nombramiento para los órganos pluripersonales, teniendo en cuenta además, una distribución geográfica equitativa, y una representación de los principales sistemas jurídicos del mundo.

A nivel regional, dentro de la Liga de Estados Arabes, existe un Comité de Expertos creado por la Carta Arabe de Derechos Humanos, de siete personas independientes e imparciales, y que actúan a título personal. Dicho Comité de Expertos, será instaurado cuando la Carta entre en vigor 227 .

En la Organización de la Unidad Africana, la Carta Africana de Derechos Humanos y de los Pueblos, crea la Comisión Africana de Derechos Humanos y de los Pueblos, compuesta de once personalidades africanas de alta consideración moral, imparcialidad e integridad, y con competencia reconocida en derechos humanos 228 .

En el Consejo de Europa, la Comisión Europea de Derechos Humanos está compuesta de un integrante por Estado Parte, siguiendo al igual que las anteriores mencionadas, el criterio de imparcialidad, integridad moral e independencia de sus integrantes 229 .

La Comisión Interamericana de Derechos Humanos, el órgano de tipo no jurisdiccional, que posee en materia de derechos humanos la Organización de los Estados Americanos, se compone de siete miembros, que son personas de alta autoridad moral y de reconocida versación en materia de derechos humanos 230 .

Los diferentes órganos mencionados, tiene cada uno su propia competencia, según hemos analizado en el epígrafe anterior, que van desde la protección convencional (es decir, procedimientos de informes, cuasi contenciosos de Estado contra Estado y de demandas individuales), hasta la protección extraconvencional (procedimientos especiales, para violaciones masivas y generalizadas a los derechos humanos, dentro de las Naciones Unidas).

b) Organos jurisdiccionales (Introducción)

El Derecho Internacional Contemporáneo, posee ciertas tendencias; entre ellas, podemos mencionar la subordinación de las esferas de competencia nacional, a las instancias internacionales; 
la supranacionalidad; y la autonomía de composición y funcionamiento de los órganos internacionales, independientemente de los Estados nacionales, que les han dado nacimiento.

En este marco se encuentra la creación de órganos de protección jurisdiccional de los derechos humanos; cuya consolidación, se ha plasmado en la existencia actual de dos tribunales regionales: el Tribunal Europeo de Derechos Humanos y la Corte Interamericana de Derechos Humanos 231 .

Las composiciones de ambos órganos son diferentes: en el sistema europeo, existe un juez por Estado parte de la Convención 232 . En el sistema interamericano los jueces de la Corte son siete 233 .

Los funcionamientos de ambos tribunales también marcan diferencias; incluso la práctica, detalla la importancia de la vasta jurisprudencia contenciosa del Tribunal Europeo de Derechos Humanos, frente a los pocos casos de la misma competencia de la Corte Interamericana; y a la inversa, la trascendencia de la competencia consultiva de la Corte Interamericana, frente a la casi nula actuación del Tribunal Europeo en dicha esfera 234 .

Un estudio amplio sobre la Corte Interamericana, sus competencias y funciones, las opiniones consultivas, casos resueltos y en trámite, son objeto del Capítulo siguiente. 


\title{
LA CORTE INTERAMERICANA DE DERECHOS HUMANOS: COMPETENCIAS Y ASUNTOS TRATADOS
}

\begin{abstract}
Sumario: I.- De la Corte Interamericana de Derechos Humanos; II.- Las competencias de la Corte Interamericana de Derechos Humanos; II.1.- La competencia consultiva; II.2.- La competencia contenciosa; II.3.- Las medidas provisionales; III.- La jurisprudencia de la Corte Interamericana; III.1.- Las Opiniones Consultivas emitidas por la Corte Interamericana; III.2.- Los casos contenciosos ante la Corte Interamericana; III.2.a.- Casos resueltos por la Corte; III.2.b.- Casos en trámite ante la Corte (sin sentencia sobre el fondo); III.3.- Medidas provisionales dictadas por la Corte (mención).
\end{abstract}

\section{I.- De la Corte Interamericana de Derechos Humanos}

La Corte Interamericana de Derechos Humanos, es uno de los órganos que tienen por función, aspectos atinentes a la protección de los derechos y libertades fundamentales, en todos los Estados que forman parte de la Organización de los Estados Americanos 235.

La Organización de los Estados Americanos, tal como hemos visto, ha sido fundada en 1948 en ocasión de celebrarse la Novena Conferencia Interamericana, llevada a cabo en la ciudad de Bogotá. A la fecha, la Carta de la OEA cuenta con treinta y cinco Estados partes.

Esa misma Novena Conferencia Interamericana, había recomendado al Comité Jurídico Interamericano, la elaboración de un proyecto de estatuto, para la creación y el funcionamiento de una Corte Interamericana de Derechos Humanos, basada en un proyecto presentado por el gobierno de Brasil 236 .

No obstante aquella resolución, debió esperarse hasta la adopción de un instrumento convencional, para la creación de un tribunal interamericano de derechos humanos.

En efecto, la Corte Interamericana de Derechos Humanos, ha sido creada por la Convención Americana sobre Derechos Humanos 237 , tratado elaborado en la ciudad de San José de Costa Rica el 22 de noviembre de 1969, y que, conforme al cumplimiento de las disposiciones de su texto, entró en vigor el 18 de julio de 1978.

La Corte está constituida por siete jueces, los cuales deben ser nacionales de los Estados miembros de la Organización de los Estados Americanos. Los magistrados son elegidos a título personal, entre juristas de la más alta autoridad moral, y de reconocida competencia en materia de derechos humanos; y duran seis años en sus funciones 238 .

Como veremos en los acápites siguientes, ciertas actuaciones de la Corte Interamericana de Derechos Humanos, comprenden a todos los Estados miembros de la Organización de los Estados Americanos, sin importar que los mismos, hayan o no ratificado el Pacto de San José de Costa Rica.

En sentido concordante, Cecilia Medina menciona que «... aunque la Corte es calificada en su Estatuto como un órgano de la Convención, sus funciones exceden claramente ese tratado...» 239 .

Para los casos contenciosos (es decir, cuando un Estado es acusado de violar alguno de los derechos establecidos en la Convención Americana sobre Derechos Humanos), el gobierno demandado puede designar un juez ad hoc cuando en la Corte no exista un miembro de su nacionalidad 240 . 
El «juez ad hoc» es, sin duda, una institución típica del viejo Derecho Internacional clásico (propia de los procesos de arbitraje), donde la preeminencia de la soberanía estatal frente a las Organizaciones Internacionales, era absoluta.

Consideramos que, a la luz de la evolución experimentada en los campos del Derecho Internacional de los Derechos Humanos, y del Derecho Internacional Contemporáneo, la existencia de «jueces ad hoc», no encuentra fundamento alguno, en un tribunal internacional para proteger los derechos y libertades fundamentales de la persona.

Efectivamente, la supervivencia de esta institución en un proceso por derechos humanos, puede derivar en la politización del mismo, en desmedro de la juridización que debe reinar en todo juicio, que debe ser más estricta aún cuando la materia de que se trata es la dignidad humana 241 .

\section{II.- Las competencias de la Corte Interamericana de Derechos Humanos}

La Corte Interamericana tiene dos funciones substanciales; llamadas competencias consultiva y contenciosa. También, entre sus atribuciones principales, la Corte se encuentra facultada para dictar medidas provisionales.

En estas tres tareas, que consideramos complementarias, se concentran las actividades centrales del Tribunal, para la protección de los derechos humanos en el continente americano.

En los acápites siguientes, haremos un estudio de ambas funciones principales; y una mención de los asuntos, que han merecido el análisis por la Corte, sobre la aplicación de medidas provisionales.

\section{1.- La Competencia Consultiva 242}

La Corte Interamericana de Derechos Humanos, en su función consultiva, tiene por objeto emitir opiniones sobre la interpretación y alcance de las disposiciones del Pacto de San José de Costa Rica, o de otras normas de derechos humanos, que se encuentren en instrumentos internacionales en los que un Estado miembro de la OEA sea parte. El pedido de una Opinión Consultiva, puede ser realizado por cualquiera de los órganos principales, de la Organización de los Estados Americanos.

Asimismo, cualquier Estado Miembro de la Organización, se encuentra habilitado puede consultar a la Corte en los aspectos señalados; y además, puede pedir opiniones a la Corte sobre la compatibilidad de su legislación interna y los mencionados instrumentos internacionales.

En relación a la naturaleza de la función consultiva de la Corte Interamericana de Derechos Humanos, algunos autores destacan que «... La función consultiva que confiere a la Corte el art. 64 de la Convención es única en el derecho internacional contemporáneo. Como la Corte ya lo ha expresado en otra oportunidad, ni la Corte Internacional de Justicia ni la Corte Europea de Derechos Humanos han sido investidas con la amplia función consultiva que la Convención ha otorgado a la Corte Interamericana...» 243.

Efectivamente, la Corte Internacional de Justicia, órgano judicial principal de las Naciones Unidas, sólo puede recibir pedidos de Opinión Consultiva directamente, por parte de la Asamblea General de la Organización o del Consejo de Seguridad; e indirectamente (es decir con la autorización de la Asamblea General), del resto de órganos y organismos especializados de las Naciones Unidas 244 .

De forma tal, que los Estados miembros de las Naciones Unidas, no pueden solicitar una Opinión Consultiva de la Corte Internacional de Justicia.

Si comparamos la tarea llevada adelante por el Tribunal Europeo de Derechos Humanos y la Corte Interamericana de Derechos Humanos, veremos que el desarrollo de las opiniones consultivas ha sido más rico y abundante en el órgano interamericano 245 .

En el sistema europeo, la legitimación activa para solicitar opiniones consultivas, está restringida al Comité de Ministros del Consejo de Europa, y vedada a los Estados Partes del Tratado de Roma 246 .

En cuanto al objeto de una Opinión Consultiva, también es más restringida la esfera de acción del Tribunal Europeo de Derechos Humanos, que aquella que corresponde a la Corte Interamericana, debido a que el Tribunal Europeo, sólo puede interpretar la Convención Europea de Derechos Humanos y sus Protocolos 247. 
Finalmente, a diferencia del sistema interamericano, un Estado parte del Convenio Europeo, no puede solicitar al Tribunal Europeo una Opinión Consultiva sobre el grado de compatibilidad entre su legislación interna, y los instrumentos internacionales de protección de los derechos humanos 248 .

Berta Santoscoy-Noro, considera que a pesar de la amplitud de la función consultiva, el artículo 64 de la Convención Americana, no permite la posibilidad de que algún órgano de la OEA pida una opinión sobre la compatibilidad de una ley de algún Estado miembro y los instrumentos internacionales de derechos humanos «... A pesar de la vasta competencia de la Corte, el segundo parágrafo del artículo 64 le impone una limitación al indicar que solo los Estados miembros de la Organización están facultados para solicitar una opinión sobre la compatibilidad de cualquiera de sus leyes internas y los instrumentos internacionales que describe el párrafo 1 del mismo artículo...» 249 .

Las Opiniones Consultivas, no tienen el efecto obligatorio que poseen las sentencias contra Estados establecidas por la Corte en ejercicio de su función contenciosa; sin embargo, algunos autores subrayan su importancia «... En la práctica las opiniones de la Corte pueden gozar de gran autoridad y llenar una importante función como medio de protección de los derechos humanos, en especial si se tienen en cuenta las dificultades con que ha tropezado el ejercicio de su jurisdicción contenciosa...» 250 .

Volviendo al sistema interamericano, podemos afirmar inicialmente que dentro de los alcances de su función consultiva y en el desarrollo jurisprudencial de la misma, la Corte Interamericana ha fortalecido el objetivo de favorecer el respeto a los derechos humanos 251 .

\section{2.- La competencia contenciosa}

En su tarea contenciosa, la Corte Interamericana de Derechos Humanos puede conocer en casos contra Estados, y juzgar si éstos han violado alguna disposición de la Convención Americana sobre Derechos Humanos; sólo la Comisión Interamericana de Derechos Humanos y los Estados, pueden llevar un caso ante la Corte 252.

Según Héctor Fix Zamudio, el procedimiento contencioso de la Corte Interamericana de Derechos Humanos «... se inspira esencialmente en el establecido para las controversias sometidas a la Corte Internacional de Justicia y a la Corte Europea de Derechos Humanos, en cuyos lineamientos procesales existe un paralelismo, que con algunos matices han sido recogidos por la Convención Americana y por el Reglamento de la Corte Interamericana...» 253.

En sentido concordante, y citando una de las similitudes, Juan Carlos Hitters subraya que la facultad de aceptación de la competencia contenciosa de la Corte Interamericana, tal como sucede en la Corte Internacional de Justicia y el Tribunal Europeo de Derechos Humanos, se da a través de la "cláusula opcional», que da a los Estados la posibilidad de realizar la declaración pertinente en cualquier momento 254 .

Para que un Estado sea demandado ante la Corte Interamericana, es necesario que éste, además de haber ratificado la Convención Americana sobre Derechos Humanos, haya hecho una declaración especial de aceptación de la competencia contenciosa 255.

De los 35 Estados miembros de la OEA; 25 han ratificado el Pacto de San José de Costa Rica; y, hasta el momento, sólo 17 de los 25 Estados partes del Pacto, han hecho la declaración de reconocimiento de competencia contenciosa de la Corte 256 .

Héctor Gros Espiell aclara que el sometimiento de un caso a la Corte Interamericana, no constituye una apelación; ya que el Tribunal «... no actúa en vía de apelación o como forma atípica de un recurso de casación, de revisión o de nulidad, sino en ejercicio de una función jurisdiccional propia...» 257 .

La víctima o sus representantes, no pueden actualmente ser partes en un caso contencioso de la Corte Interamericana (no poseen el llamado «locus standi»), aunque sus abogados actúan como «asesores de la comisión» en los casos. En efecto, Juan Antonio Carrillo Salcedo y Ana Salado Osuna hacen notar que, desde el primer caso sometido a la Corte Europea de Derechos Humanos, la Comisión Europea permitió al abogado de la víctima a intervenir como asesor de su delegación, y 
que igual práctica ha sido seguida en el sistema interamericano, desde el caso Velásquez Rodríguez 258 .

Pero en el desarrollo del sistema interamericano, no se ha alcanzado aún un instrumento como el Protocolo IX Anexo al Convenio Europeo para la Protección de los Derechos Humanos y las Libertades Fundamentales, y menos aún, se plantea la posibilidad de seguir los pasos del Protocolo $\mathrm{XI}$ que, como ya mencionamos, revoluciona a todo el mecanismo establecido dentro del Consejo de Europa 259 .

De la falta de acceso directo del individuo al Tribunal, o de la posibilidad de defender su caso por sí («locus standi») ante la Corte Interamericana pueden derivarse situaciones de indefensión; creemos que «... La imposibilidad de la víctima o de sus representantes de acceder por sí a la Corte Interamericana, ha tenido consecuencias negativas para la protección a los derechos humanos en el sistema... La legitimación activa del individuo delante de las jurisdicciones internacionales, en particular los tribunales de derechos humanos, es un paso necesario para garantizar la eficacia de cualquier sistema de protección..." 260 .

Al menos, tal como el destacado profesor Cançado Trindade afirma al respecto: «... La preocupación de la Corte en asegurar un proceso equitativo y justo debe necesariamente abarcar la cuestión de asegurar igualmente alguna forma de locus standi de las presuntas víctimas (o sus representantes legales) ante la propia Corte, en casos que ya le hayan sido enviados por la Comisión» 261 .

En igual sentido, Juan Méndez sostiene que «... El desarrollo progresivo de la protección de los derechos humanos en el plano internacional exige que se considere seriamente la ampliación del ámbito procesal de las víctimas en los procesos de responsabilidad estatal, como ya lo está haciendo el Consejo de Europa...» 262 .

Se ha dado un importante paso, con la última reforma integral al reglamento de la Corte Interamericana, por medio de la cual, en lo que nos ocupa aquí, la víctima o sus representantes tendrán plena participación en la etapa de reparaciones, hecho que sucede desde la entrada en vigencia de dicha modificación substancial, el 1 de enero de 1997263.

Si la Corte Interamericana, concluye que un Estado ha violado alguno de los derechos o libertades protegidos por la Convención Americana sobre Derechos Humanos, dispone que se garantice al lesionado (cuando ello es posible) el derecho o libertad de que se trate.

Asimismo, en su sentencia, la Corte determina que se reparen las consecuencias, de la medida o situación que ha configurado la vulneración de esos derechos, y establece el pago de una justa indemnización para la parte lesionada 264 .

En cuanto al contenido que puede tener la indemnización que disponga el tribunal, la propia Corte Interamericana ha sostenido en sus sentencias que «... La reparación del daño ocasionado por la infracción de una obligación internacional consiste en la plena restitución (restitutio in integrum), lo que incluye el restablecimiento de la situación anterior y la reparación de las consecuencias que la infracción produjo y el pago de una indemnización como compensación por los daños patrimoniales y extrapatrimoniales, incluyendo el daño moral...» 265 .

La Corte Interamericana de Derechos Humanos, ha realizado diferentes aplicaciones legales del Derecho Internacional, y recurriendo a distintas fuentes para la determinación de indemnizaciones que contemplen el principio de la «reparación integral» 266.

La Corte Interamericana, en su función contenciosa, ha dictado muchas resoluciones y sentencias valiosas; es dable señalar, en este sentido, a las decisiones tomadas en dos de los casos hondureños (Velásquez Rodríguez y Godínez Cruz), que han sentado jurisprudencia respecto a muchos aspectos, tanto procedimentales, como de fondo.

Otro de los fallos técnicamente ricos de la Corte Interamericana de Derechos Humanos, es la sentencia sobre reparaciones dictada en el caso Aloeboetoe; particularmente en los aspectos referentes a la determinación de la indemnización, la aplicación normativa, y los modos de cumplimiento de aquella 267 (ver página siguiente). 
La Convención Americana sobre derechos humanos, también determina que la parte del fallo que disponga indemnización compensatoria, se podrá ejecutar en el respectivo país, por medio del procedimiento interno vigente, para la ejecución de sentencias contra el Estado 268 .

La disposición citada, en palabras de Víctor Rodríguez Rescia, no tiene analogía con ninguna otra de la Convención Europea sobre Derechos Humanos, y es la que «... permite materializar en última instancia el cumplimiento del fallo indemnizatorio y de allí su viabilidad...» 269 .

\section{3.- Las medidas provisionales}

La Convención Americana sobre Derechos Humanos, tiene en cuenta la probabilidad de que la Corte Interamericana, disponga la adopción de medidas provisionales que ésta estime pertinentes; ya sea en los casos que estén bajo su conocimiento, como así también en asuntos que no se encuentren aún sometidos a su jurisdicción, donde, para este supuesto particular, puede dictar las medidas provisionales a pedido de la Comisión 270 .

Los requisitos para que la Corte Interamericana pueda disponer medidas provisionales, son que el Estado contra el cual se dicten las medidas haya ratificado la Convención Americana sobre Derechos Humanos, y que además, haya aceptado la competencia contenciosa de la Corte 271 ; asimismo, deben tratarse de asuntos que revistan características de extrema gravedad y urgencia; por último, la adopción de las medidas provisionales, debe ser necesaria para evitar daños irreparables a las personas. 272 .

Las medidas provisionales no son autónomas, sino que se encuentran subordinadas a algún caso que se esté tramitando ante alguno de los órganos del sistema, y que pueda ser tratado en jurisdicción contenciosa, por la Corte Interamericana de Derechos Humanos.

Puede observarse un doble carácter de las medidas provisionales reguladas en el sistema interamericano: por un lugar, otorgan garantías que colaboran en la realización de la justicia en un caso en trámite (función tradicional de las medidas cautelares); por el otro, y de acuerdo a las modalidades de su aplicación, tienden a proteger derechos humanos fundamentales de personas que pueden sufrir daños irreparables 273 .

Cuando la Corte Interamericana no se encuentre sesionando, las medidas las puede disponer el presidente del Tribunal; luego, le corresponde al pleno de sus integrantes, la decisión acerca de ratificar o no, la providencia tomada por aquel 274 .

Existe, en el desarrollo del sistema interamericano a lo largo del tiempo, una tendencia a hacer un uso cada vez más frecuente de las medidas provisionales.

\section{III.- La jurisprudencia de la Corte Interamericana}

En su trabajo, la Corte Interamericana ha dictado numerosas providencias; las hemos clasificado en relación a las distintas competencias de la Corte, en opiniones consultivas, casos contenciosos y medidas provisionales. Seguidamente haremos una síntesis de ellas.

1.- Las opiniones consultivas emitidas por la Corte Interamericana

La Corte Interamericana de Derechos Humanos, ha resuelto desde 1982, catorce Opiniones Consultivas, existiendo una décimo quinta opinión consultiva formulada por el gobierno de Chile, que el Tribunal resolverá en el mes de noviembre de 1997.

La primera Opinión Consultiva, fue solicitada por el gobierno de Perú el 22 de abril de 1982; y el objeto de la consulta, ha sido en torno al alcance de la propia función consultiva del tribunal.

En particular, el gobierno peruano formuló la pregunta sobre cuál es el sentido que debe dársele a la frase «otros tratados», que prescribe el art. 64 de la Convención Americana sobre Derechos Humanos.

Esta norma, es la más importante disposición que prevé la Convención Americana en materia consultiva; ya que establece, en primer lugar, cuales son los instrumentos que la Corte Interamericana, puede interpretar cuando se desempeña en dicha función 275 .

la Corte ha señalado en su dictamen, por unanimidad, que su competencia consultiva puede ejercerse «... en general, sobre toda disposición, concerniente a la protección de los derechos 
humanos, de cualquier tratado internacional aplicable en los Estados americanos, con independencia de que sea bilateral o multilateral, de cuál sea su objeto principal o de que sean o puedan ser partes del mismo Estados ajenos al sistema interamericano» 276 .

La segunda Opinión Consultiva, fue solicitada por la Comisión Interamericana de Derechos Humanos el 28 de junio de 1982; y su consulta, ha sido respecto a cuál es el momento de la entrada en vigencia de la Convención Americana para un Estado que ha ratificado el Pacto de San José de Costa Rica, pero ha formulado reservas al mismo 277 .

La respuesta de la Corte, ha tenido el propósito de vincular lo antes posible a los Estados que ratifiquen la Convención; así, luego de realizar un análisis de las disposiciones pertinentes de la Convención de Viena sobre Derecho de los Tratados de 1969 en materia de reservas, y de la propia naturaleza de los instrumentos jurídicos de derechos humanos, ha concluido en su resolución del 24 de setiembre de 1982, que la Convención Americana sobre Derechos Humanos, entra en vigencia para un Estado que la ratifique o se adhiera a ella, con o sin reservas, en la fecha del depósito de su instrumento de ratificación o adhesión, y sin esperar la aceptación de las reservas por parte de los otros Estados partes 278 .

La tercera Opinión Consultiva, ha sido pedida por la Comisión Interamericana de Derechos Humanos el 15 de abril de 1983, con el propósito de que la Corte Interamericana, interprete el alcance de las restricciones a la pena de muerte, que contiene el artículo 4 de la Convención Americana sobre Derechos Humanos 279 .

Dicha consulta (si bien ha sido formulada en términos amplios), estaba relacionada con la actitud de Guatemala, que había ampliado el marco de aplicación de la pena de muerte en su legislación interna; y en virtud de dicha política, ya existían condenas impuestas, e incluso algunas ejecuciones llevadas a cabo.

La Corte resolvió, el 8 de setiembre de 1983, que la Convención prohibe absolutamente la extensión de la pena de muerte; y que si un Estado ha hecho reserva del artículo 4.4 de la Convención, esa reserva no le permite legislar con posterioridad, para extender la aplicación de la pena de muerte respecto de delitos para los cuales no estaba contemplada anteriormente 280 .

La cuarta Opinión Consultiva, la formuló el gobierno de Costa Rica el 8 de agosto de 1983, debido a que iba a reformar su Constitución Nacional.

Al tener dudas sobre la compatibilidad de algunas de las reformas propuestas (respecto a la naturalización) Costa Rica preguntó al Tribunal, si esas modificaciones para su Constitución Nacional, eran o no compatibles con la Convención Americana sobre Derechos Humanos.

La Corte Interamericana, en primer lugar tuvo que definir si era o no competente para decidir la cuestión; ya que el artículo 64 de la Convención Americana sobre Derechos Humanos (que establece el alcance de su función consultiva), dice que ella podrá, a solicitud de un Estado Miembro de la OEA, dar opinión respecto de la compatibilidad de las leyes internas de ese Estado, y la Convención u otros tratados de derechos humanos.

De la letra del artículo en cuestión, no se infiere directamente que la Corte pueda interpretar proyectos de legislación, como era el caso planteado por Costa Rica 281 .

La Corte Interamericana de Derechos Humanos, en su decisión del 19 de enero de 1994, e interpretando la naturaleza de su función consultiva, concluyó que tenía competencia para decidir la cuestión; y señaló, al momento de resolver el fondo de la consulta planteada, que las reformas propuestas no eran incompatibles con el Pacto de San José de Costa Rica, excepto una de ellas, la cual consagraba condiciones preferentes para la naturalización por causa de matrimonio, en favor de uno sólo de los cónyuges 282 .

La quinta Opinión Consultiva, también fue formulada por el gobierno costarricense; el cual formalizó su pedido a la Corte, por comunicación del 8 de julio de 1985.

El objeto de la consulta, aludía a la interpretación de los artículos 13 (referido a la libertad de pensamiento y expresión) y 29 (referido a las normas de interpretación), de la Convención Americana, y la compatibilidad de dichas normas, con la Ley Orgánica del Colegio de Periodistas de Costa Rica. 
La Corte resolvió, el 13 de noviembre de 1985, que la colegiación obligatoria de periodistas, en cuanto impida el acceso de cualquier persona al uso pleno de los medios de comunicación social, como vehículo para expresarse o para transmitir información, es incompatible con el artículo 13 de la Convención Americana sobre Derechos Humanos; y que la Ley Orgánica del Colegio de Periodistas de Costa Rica, en cuanto impide a ciertas personas el pertenecer al Colegio de Periodistas y, por consiguiente, el uso pleno de los medios de comunicación, es incompatible con el artículo 13 de la Convención Americana sobre Derechos Humanos 283.

La sexta Opinión Consultiva, fue demandada el 14 de agosto de 1985 por el gobierno de la República Oriental del Uruguay, en relación al alcance de la expresión «leyes» en el artículo 30 de la Convención Americana sobre Derechos Humanos. Esta norma prescribe la forma en que deben aplicarse las restricciones a los derechos que están permitidas, dentro del capítulo correspondiente a la suspensión de garantías, interpretación y aplicación 284 .

La Corte, el 9 de mayo de 1986, resolvió que la palabra «leyes», está referida en la Convención Americana, como norma jurídica de carácter general, emanada de los órganos legislativos constitucionalmente previstos y democráticamente elegidos; y elaborada según el procedimiento establecido por las constituciones de los Estados Partes, para la formación de las leyes 285 .

La séptima Opinión Consultiva, ha sido solicitada por el gobierno de Costa Rica, el 1 de octubre de 1985, para que la Corte Interamericana de Derechos Humanos, se manifieste sobre la interpretación y el alcance del artículo 14.1 (derecho de rectificación o respuesta), en relación con los artículos 1.1 (obligación de respetar los derechos) y 2 (deber de los Estados de adoptar disposiciones de derecho interno), de la Convención Americana.

La Corte resolvió, el 29 de agosto de 1986, que el derecho de rectificación es internacionalmente exigible; y los Estados, tienen la obligación de respetar y garantizar su libre y pleno ejercicio. Asimismo dijo el Tribunal, que si en un Estado Parte no puede ejercerse dicho derecho, igualmente existe la obligación para el Estado, de adoptar las medidas legislativas o de otro carácter, que fueran necesarias; y que la palabra «Ley» (del artículo 14.1 de la Convención), está relacionada con las obligaciones asumidas por los Estados Partes en el artículo 2 de la Convención; y que las medidas legislativas, deben entenderse en su sentido más amplio; es decir, cualquier medida interna que resulte adecuada, para hacer efectivos los derechos que regula la Convención Americana sobre Derechos Humanos 286 .

La octava Opinión Consultiva, ha sido solicitada a la Corte por la Comisión Interamericana de Derechos Humanos, el 10 de octubre de 1986.

El objeto de la consulta, ha sido la interpretación de los artículos 25.1 (derecho a la protección judicial) y 7.6 (derecho a la garantía de hábeas corpus), en relación con la última frase del artículo 27.2 de la misma (enumeración de los derechos y garantías que no pueden suspenderse en ninguna ocasión), de la Convención Americana sobre Derechos Humanos. Concretamente, si el derecho a la protección judicial y a la garantía de hábeas corpus, pueden suspenderse conforme al Pacto de San José de Costa Rica 287.

La Corte Interamericana de Derechos Humanos, ha resuelto el 30 de enero de 1987, que los procedimientos consagrados en los artículos 25.1 y 7.6 de la Convención Americana sobre Derechos Humanos, no pueden ser suspendidos conforme al artículo 27.2 de la misma; porque constituyen garantías judiciales indispensables, para proteger derechos y libertades que tampoco pueden suspenderse, según la misma disposición 288 .

El noveno pedido de Opinión Consultiva, lo realizó el gobierno de la República Oriental del Uruguay, el 17 de setiembre de 1986. La solicitud, requería que la Corte Interamericana, brinde su opinión acerca del alcance que tiene, la prohibición de suspender las garantías judiciales indispensables para la protección de los derechos, que se encuentran mencionados en el artículo 27.2, de la Convención Americana sobre Derechos Humanos.

En buena medida, este pedido del gobierno de Uruguay, dio lugar a la Corte para que ésta completara lo dispuesto en la anterior Opinión Consultiva emitida; ya que ambas cuestiones se referían a la suspensión de garantías, particularmente en torno al segundo párrafo del artículo veintisiete, del Pacto de San José de Costa Rica. 
La Corte Interamericana de Derechos Humanos, dispuso por decisión del 6 de octubre de 1987, que deben considerarse como garantías indispensables no susceptibles de suspensión, el Hábeas Corpus, el Amparo o cualquier otro recurso efectivo destinado a garantizar el respeto a los derechos y libertades, que la Convención considera como no suspendibles 289 .

La décima Opinión Consultiva, fue pedida el 17 de febrero de 1988, por el gobierno de Colombia; quien preguntó si en el ejercicio de la función consultiva (artículo 64 de la Convención), la Corte Interamericana podía interpretar a la Declaración Americana de los Derechos y Deberes del Hombre, instrumento jurídico adoptado en 1948, en la misma conferencia interamericana que dio nacimiento a la Organización de los Estados Americanos 290 .

La Corte resolvió, el 14 de julio de 1989, que el artículo 64.1 de la Convención Americana le autoriza, a solicitud de un Estado Miembro de la OEA o, en lo que les compete, de uno de los órganos de la misma; para rendir opiniones consultivas sobre la interpretación de la Declaración Americana de los Derechos y Deberes del Hombre, en el marco y dentro de los límites de la competencia del Tribunal; y en relación con la Carta constitutiva de la Organización de los Estados Americanos, y el Pacto de San José de Costa Rica, u otros tratados concernientes a la protección de los derechos humanos en los Estados Americanos 291.

La décimo primera Opinión Consultiva, ha sido solicitada por la Comisión Interamericana de Derechos Humanos, el 31 de enero de 1989. Como ya hemos visto en el Capítulo II, el carácter subsidiario de la protección internacional de los derechos humanos, exige como regla el agotamiento de los recursos internos 292 .

La Comisión Interamericana de Derechos Humanos, preguntó entonces a la Corte, si corresponde aplicar el requisito de agotamiento de los recursos internos, a un indigente que por circunstancias económicas no puede hacer uso de estas vías; y formuló la misma pregunta, respecto a algún reclamante que no pueda hacer uso de los recursos internos, por la existencia de un temor generalizado en los círculos jurídicos del país donde aquel resida, respecto a la defensa de su caso.

La Corte Interamericana de Derechos Humanos, resolvió el 10 de agosto de 1990, que si por razones de indigencia o debido a la existencia de un temor generalizado de los abogados para representarlo, un reclamante ante la Comisión Interamericana de Derechos Humanos se ha visto impedido de agotar los recursos internos, no puede exigírsele el cumplimiento de ese requisito 293 .

La décimo segunda Opinión Consultiva, ha sido solicitada por el gobierno de Costa Rica; quien pidió el 22 de febrero de 1991, que la Corte se expida sobre la compatibilidad de un proyecto de ley de su país, con el artículo 8.2.h de la Convención Americana.

La Corte Interamericana, el 6 de diciembre de 1991, entendió que una respuesta a las preguntas de Costa Rica, podría traer como resultado una desvirtuación de la jurisdicción contenciosa; debido a que se estaban tramitando ante la Comisión Interamericana, algunos casos sobre el objeto de la consulta. Por ende, la Corte decidió no responder a la pregunta formulada por Costa Rica 294 .

La décimo tercera Opinión Consultiva, ha sido solicitada conjuntamente por los gobiernos de Uruguay y Argentina; quienes elevaron su pedido, el 17 de diciembre de 1991.

Estos Estados, preguntaron a la Corte respecto a algunas atribuciones de la Comisión Interamericana sobre Derechos Humanos; en particular, si esta tiene facultades, para opinar sobre la regularidad jurídica de leyes sancionadas internamente de acuerdo con la Constitución de un Estado; también interrogaron si es posible que la Comisión, luego de haberse pronunciado contra la admisibilidad de un caso, emita su opinión sobre el fondo del mismo; y si se pueden subsumir en uno solo, los informes que prescriben los artículos 50 y 51 de la Convención Americana sobre Derechos Humanos.

La Corte ha resuelto, el 16 de julio de 1993, que la Comisión tiene competencia, para calificar a cualquier norma de derecho interno de un Estado Parte como violatoria de los derechos y obligaciones enumerados en la Convención Americana; que si la Comisión ha declarado inadmisible un caso, no cabe pronunciamiento sobre el fondo del asunto; y que los informes que contemplan los artículos 50 y 51, son dos informes separados, el primero de los cuales no puede ser publicado. El segundo informe (del artículo 51), sí puede ser publicado por la Comisión, previa 
decisión tomada por este cuerpo por la mayoría de votos, y después de transcurrido el plazo que haya otorgado al Estado para tomar las medidas adecuadas 295 .

La décimo cuarta Opinión Consultiva, ha sido pedida por la Comisión Interamericana de Derechos Humanos el 8 de noviembre de 1993; dos temas se encontraban en juego dentro de la consulta realizada por la Comisión.

La primera cuestión formulada, es cuáles serían los efectos jurídicos de una ley de un Estado Parte, que viola manifiestamente las obligaciones que éste había contraído, desde el momento en que ha ratificado la Convención.

La segunda cuestión, interroga sobre cuales serían las responsabilidades y obligaciones para los agentes o funcionarios del Estado, que han ejecutado una ley, cuyo cumplimiento se traduce en una violación manifiesta de la Convención.

La Corte Interamericana ha resuelto, el 9 de diciembre de 1994, que la expedición de una ley manifiestamente contraria a las obligaciones asumidas por un Estado, al ratificar o adherir a la Convención Americana sobre Derechos Humanos, constituye una violación de ésta y; para el caso que esa violación afecte derechos y libertades protegidos respecto de individuos determinados, se genera la responsabilidad internacional de tal Estado.

Asimismo, que el cumplimiento de una ley manifiestamente violatoria de la Convención, por parte de agentes o funcionarios del Estado, genera responsabilidad internacional para éste último. En caso que el acto de cumplimiento, constituya per se un crimen internacional, genera también la responsabilidad internacional, para los agentes o funcionarios que lo ejecutaron 296 .

\section{2.- Los Casos Contenciosos ante la Corte Interamericana}

En materia contenciosa, existen casos que la Corte ya ha resuelto sobre el fondo; e incluso, dictaminado sobre las reparaciones cuando estas procedían. También, naturalmente, hay asuntos en trámite ante la Corte, en los cuales no hay aún pronunciamiento del Alto Tribunal sobre el fondo de la cuestión. Tal como venimos de hacerlo con las opiniones consultivas, resumimos los principales hechos y decisiones.

a) Casos resueltos por la Corte

* Viviana Gallardo (Costa Rica)

El primer caso contencioso que llegó a la Corte, fue enviado por el gobierno de Costa Rica (caso Viviana Gallardo); pero la Corte por sentencia del 8 de setiembre de 1983, decidió que no podía entender en el asunto, porque el caso no había sido tratado aún por la Comisión Interamericana de Derechos Humanos; de forma tal, que aunque el gobierno haya renunciado a tratar el asunto ante la Comisión, la Corte no lo aceptó, porque consideró que ello perjudica los derechos de la víctima 297

* Velásquez Rodríguez (Honduras) 298

El 24 de abril de 1986, la Comisión Interamericana de Derechos Humanos decidió someter a la consideración de la Corte Interamericana, un caso debido a la desaparición forzada de un estudiante de la Universidad Autónoma de Honduras, quien fue apresado violentamente y sin orden judicial, por personas pertenecientes a la Dirección Nacional de Investigación y del G-2 de las Fuerzas Armadas de Honduras, el 12 de setiembre de 1981; Posteriormente, fue trasladado junto a otros detenidos, a celdas ubicadas en el barrio El Manchén de Tegucigalpa, donde fue sometido a torturas. Luego, el gobierno ha negado de manera sistemática su detención.

La Corte Interamericana, en su sentencia del 26 de junio de 1987, desechó las excepciones preliminares interpuestas por el gobierno 299 ; y en su sentencia del 29 de julio de 1988, encontró a Honduras responsable de la violación de los deberes de respeto y garantía del derecho a la libertad personal, del derecho a la integridad personal, y del derecho a la vida regulados en la Convención Americana de Derechos Humanos, en perjuicio de Angel Manfredo Velásquez Rodríguez; y estableció además, que Honduras se encontraba obligada a pagar una justa indemnización compensatoria a sus familiares 300 .

La Corte ha dictado, posteriormente, una sentencia sobre indemnización compensatoria, determinando el monto y la forma de percepción de dicha indemnización 301 . 
* Godínez Cruz (Honduras)

La Comisión Interamericana, llevó ante la Corte el 24 de abril de 1986, un caso referido a la desaparición forzada sucedida el 22 de julio de 1982, de Saúl Godínez Cruz, en momentos en que se dirigía a un instituto en el cual trabajaba como profesor, y fue detenido por tres personas (una de ellas con uniforme militar), e introducido en un vehículo de doble cabina sin placas de identificación.

La Corte Interamericana, en su sentencia del 26 de junio de 1987, desechó las excepciones preliminares interpuestas por el gobierno 302 ; y en su sentencia del 20 de enero de 1989, encontró a Honduras responsable de la violación de los deberes de respeto y garantía del derecho a la libertad personal, del derecho a la integridad personal, y del derecho a la vida, regulados en la Convención Americana de Derechos Humanos, en perjuicio de Saúl Godínez Cruz; y estableció además, que Honduras se encontraba obligada a pagar una justa indemnización compensatoria a sus familiares 303 .

Igualmente que en el caso Velásquez Rodríguez, la Corte ha dictado posteriormente una sentencia sobre indemnización compensatoria, fijando el monto y la forma de percepción de dicha indemnización 304 (ver página siguiente) .

* Fairén Garbi y Solís Corrales (Honduras)

El 24 de abril de 1986, la Comisión Interamericana de Derechos Humanos, sometió a la consideración de la Corte un caso por la desaparición de dos ciudadanos costarricenses: Francisco Fairén Garbi y Yolanda Solís Corrales, quiénes viajaban por tránsito en territorio hondureño hacia México.

En este caso, la Corte Interamericana de Derechos Humanos, por sentencia del 15 de marzo de 1989, declaró que no había sido probado que las desapariciones de Francisco Fairén Garbi y Yolanda Solís Corrales, hayan sido imputables al gobierno de Honduras 305 .

* Neira Alegría (Perú)

El Caso Neira Alegría contra el Perú, fue elevado por la Comisión Interamericana a la Corte el 10 de octubre de 1990. Se trata de la desaparición de Víctor Neira Alegría, Edgar Zenteno Escobar y Willam Zenteno Escobar, el 18 de junio de 1986, en momentos en que éstos se encontraban detenidos, y luego del sofocamiento de un motín, producido en el lugar de detención (se trata del penal San Juan Bautista, conocido como «El Frontón»).

El gobierno peruano, interpuso excepciones preliminares que fueron desestimadas por la Corte Interamericana de Derechos Humanos, por resolución del 11 de diciembre de 1991306.

En su sentencia sobre el fondo del asunto, pronunciada el 19 de enero de 1995, la Corte Interamericana condenó a Perú por haber violado el derecho a la vida (Art. 4), en conexión con la obligación del Estado de respetar los derechos establecidos en la Convención Americana sobre Derechos Humanos (art.1.1); y el derecho de hábeas corpus (art.7.6) en conexión con la prohibición de la suspensión de garantías (art. 27.2), en perjuicio de Víctor Neira Alegría, Edgard Zenteno Escobar y William Zenteno Escobar. Además, la Corte decidió que Perú está obligado a pagar a los familiares de las víctimas una justa indemnización compensatoria 307 .

El 19 de setiembre de 1996, la Corte dictó sentencia sobre reparaciones y costas en este caso, fijando el monto total de las indemnizaciones que debe pagar Perú a los familiares de las víctimas, y el plazo para dar cumplimiento a esta sentencia. Asimismo, determinó que el Estado está obligado a hacer todo el esfuerzo posible, para identificar los restos de las víctimas y entregarlos a sus familiares 308 .

* Cayara (Perú)

El caso Cayara contra el Perú, fue remitido por la Comisión Interamericana de Derechos Humanos el 14 de agosto de 1992, debido a que el 14 de mayo de 1988, tropas del ejército de Perú ingresaron a la población de Cayara, asesinaron al primer habitante que encontraron, y fueron hasta la iglesia del poblado donde fusilaron a cinco hombres desarmados que se encontraban desarmando un tablado. Más tarde, cuando los hombres de la población volvían del campo, los soldados les mataron con bayonetas, y enterraron los cuerpos de los muertos en un lugar cercano. También, detuvieron a tres personas cuyos cadáveres fueron encontrados posteriormente. El día anterior, un 
grupo de Sendero Luminoso había realizado una emboscada en la zona contra un convoy militar del ejército peruano, donde murieron cuatro integrantes de Sendero Luminoso, un capitán del ejército y tres soldados.

El 29 de julio de 1988, varios testigos de la masacre de Cayara fueron arrestados en sus hogares; y cinco de ellos, sufrieron desapariciones forzadas. El 14 de diciembre, el alcalde de Cayara y su secretaria, quiénes eran testigos de la masacre, fueron asesinados. Por último, el 8 de setiembre de 1989, Martha Crisóstomo García, uno de los testigos que quedaban de la masacre, fue ultimada a balazos en su domicilio a las tres de la madrugada.

El gobierno interpuso excepciones preliminares, y la Corte hizo lugar a una de ellas, por considerar que la Comisión Interamericana había interpuesto su demanda fuera del plazo fijado por el artículo 51.1 de la Convención Americana sobre Derechos Humanos 309 .

* Gangaram Panday (Suriname)

El caso Gangaram Panday contra Suriname, fue remitido a la Corte Interamericana por la Comisión Interamericana de Derechos Humanos, en agosto de 1990, debido a la detención del señor Asok Gangaram Panday por parte de la policía militar en Suriname, hecho ocurrido el 5 de noviembre de 1988, en el aeropuerto Zanderij; luego de lo cual, Gangaram Panday apareció ahorcado, en un edificio de custodia al cual había sido trasladado.

La Corte Interamericana, desechó las excepciones preliminares opuestas por el gobierno de Surinam, en su sentencia del 4 de diciembre de 1991310 .

El Tribunal determinó, el 21 de enero de 1994, que el Estado de Suriname había violado, en perjuicio de la víctima, el derecho a la libertad personal (art. 7.2) en conexión con la obligación de respetar los derechos establecidos en la Convención Americana sobre Derechos Humanos (art.1.1).

En relación al derecho a la integridad corporal, la Corte desestimó unánimemente la solicitud de la Comisión para declarar responsable al Estado de Suriname.

Por mayoría de votos, desestimó el pedido de la Comisión para declarar responsable al Estado de Suriname, de violar el derecho a la vida en perjuicio de la víctima.

Por unanimidad, la sentencia de la Corte Interamericana de Derechos Humanos, estableció una indemnización en dinero para los derecho habientes de la víctima 311 .

* Aloeboetoe (Suriname)

El caso Aloeboetoe y otros contra Suriname, fue enviado por la Comisión a la Corte el 27 de agosto de 1990, debido a los hechos producidos el 31 de diciembre de 1987, en las localidades de Atjoni y Tjongalangapassi. En el primero de los lugares, más de 20 personas fueron detenidos, golpeados y sometidos a tratos inhumanos y degradantes por soldados, bajo la sospecha de que pertenecían al Comando de la Selva.

Luego, varios de los detenidos fueron liberados, pero siete de ellos, entre los cuales se encontraba un menor de 15 años de edad, fueron llevados por un vehículo militar, del cual les hicieron descender y se ejecutó a seis de ellos. Uno fue herido pero pudo escapar, aunque posteriormente falleció en un hospital.

La Corte, por sentencia de 4 de diciembre de 1991, tomó nota del reconocimiento de responsabilidad efectuado por la República de Surinam, y dejó abierto el procedimiento, para los efectos de las reparaciones y costas del caso 312 .

En su sentencia sobre reparaciones, la Corte Interamericana además de establecer una indemnización monetaria, ordenó al Estado de Suriname, con carácter de reparación, reabrir la escuela sita en Gujaba, y dotarla de personal docente y administrativo suficiente; así como también, poner en operación el dispensario existente en el lugar 313 .

* Caballero Delgado y Santana (Colombia)

El caso Caballero Delgado y Santana contra Colombia, fue enviado a la Corte por la Comisión Interamericana de Derechos Humanos, el 24 de diciembre de 1992. Los hechos que han motivado esta presentación, fueron la detención por parte de una patrulla militar, el 7 de febrero de 1989, de Isidro Caballero Delgado (perteneciente al Movimiento 19 de abril y dirigente sindical del magisterio santandereano), y María del Carmen Santana (miembro también del Movimiento 19 de 
abril). A partir de ese momento, no se han tenido más noticias sobre los detenidos, y el gobierno colombiano negó esta detención.

El gobierno, interpuso excepciones preliminares que la Corte Interamericana, ha desechado por unanimidad, en su sentencia del 21 de enero de 1994314.

El 8 de diciembre de 1995, la Corte Interamericana de Derechos Humanos, determinó por mayoría de sus integrantes que la República de Colombia, ha violado en perjuicio de Isidro Caballero Delgado y María del Carmen Santana, los derechos a la libertad personal y a la vida (arts. 7 y 4), en relación con la obligación de respetar los derechos establecidos en la Convención Americana sobre Derechos Humanos (art.1.1).

Por mayoría de sus integrantes, la Corte resolvió que Colombia no ha violado en el caso, el derecho a la integridad personal.

Por unanimidad, la Corte decidió que Colombia no ha violado la obligación de adoptar medidas para hacer efectivos los derechos y libertades garantizados en la Convención Americana, ni las garantías judiciales en los procesos y la protección judicial de los derechos.

Por unanimidad, la Corte dispuso que Colombia no ha violado, los artículos 51.2 y 44 de la Convención Americana.

Por unanimidad, la Corte decidió que Colombia está obligada, a continuar los procedimientos judiciales por la desaparición y presunta muerte de las personas mencionadas, y proceder a la sanción, conforme a su derecho interno.

Por mayoría de sus miembros, la Corte resolvió que Colombia está obligada a pagar una justa indemnización a los familiares de las víctimas; y dejó abierto el procedimiento para la fijación de la forma y cuantía de la indemnización, y el resarcimiento de gastos 315 .

* Maqueda (Argentina)

La Corte recibió el 25 de mayo de 1994, enviado por la Comisión Interamericana de Derechos Humanos, un caso contra la República Argentina, sobre violación de los derechos a ser oído por un tribunal imparcial, presunción de inocencia, derecho de recurrir el fallo ante un tribunal superior, y garantías judiciales. Guillermo Maqueda había sido condenado por la Cámara Federal de San Martín a diez años de prisión, por delitos derivados de actos de violencia que tienen por fin atentar contra el orden constitucional y la vida democrática, en aplicación de una ley, que no contempla apelación ni recurso amplio ante ningún tribunal de alzada.

El 17 de enero de 1995, la Corte analizó el desestimiento de la acción, realizado por la Comisión Interamericana, en virtud de un acuerdo al que llegaron el Estado y el peticionante, por el cual el señor Maqueda ha quedado en libertad. En consecuencia, el Tribunal decidió admitir el desestimiento de la Comisión, y sobreseer finalmente el caso 316 .

* El Amparo (Venezuela)

El caso El Amparo contra Venezuela, fue sometido por la Comisión a conocimiento de la Corte Interamericana, el 15 de enero de 1994; motivado en que 16 pescadores residentes en el pueblo «El amparo», mientras participaban de un paseo de pesca el 29 de octubre de 1988, fueron interceptados por efectivos militares y policiales, que se encontraban realizando un operativo en la zona; tras lo cual, ejecutaron extrajudicialmente a 14 de aquellos, y dos lograron escapar.

La Corte Interamericana, por sentencia del 18 de enero de 1995, tomó nota del reconocimiento de responsabilidad efectuado por la República de Venezuela, y estableció que la misma está obligada a reparar los daños, y a pagar una justa indemnización a las víctimas sobrevivientes, y a los familiares de los fallecidos 317 .

El 14 de setiembre de 1996, la Corte Interamericana dictó sentencia sobre reparaciones y costas en este caso; fijando el monto total de las indemnizaciones, y el plazo en el cual Venezuela debe hacer efectivo el pago. Asimismo, declaró que Venezuela está obligada a continuar las investigaciones de los hechos a que se refiere el caso, y sancionar a los responsables 318 .

* Garrido y Baigorria (Argentina)

El caso ha sido llevado por la Comisión Interamericana ante la Corte, el 29 de mayo de 1995, debido a la detención, ocurrida el 28 de abril de 1990, en el interior del parque San Martín, de 
Adolfo García y Raúl Baigorria; hecho imputable a agentes de la Policía de la Provincia de Mendoza. Desde allí, se desconoce el paradero de las personas mencionadas.

La Corte Interamericana, por sentencia del 2 de febrero de 1996, tomó nota del reconocimiento efectuado por la Argentina, de los hechos articulados en la demanda y de su reconocimiento de responsabilidad internacional por los mismos; y concedió a las partes, seis meses para llegar a un acuerdo sobre reparaciones e indemnizaciones, reservándose el derecho de revisar dicho acuerdo. Para el caso de que las partes no lleguen a un acuerdo, la Corte se reserva el derecho de continuar entendiendo en el procedimiento sobre reparaciones 319 .

b) Casos en trámite ante la Corte (sin sentencia sobre el fondo)

* Genie Lacayo (Nicaragua)

La Comisión Interamericana de Derechos Humanos elevó este asunto a la Corte el 6 de enero de 1994, debido a que agentes del gobierno de Nicaragua realizaron acciones, iniciadas el 23 de julio de 1991, que han causado una denegación de justicia, impidiendo una investigación imparcial para sancionar a los responsables de la muerte de Jean Paul Genie Lacayo, quien fuera asesinado por efectivos militares el 28 de octubre de 1990. La Comisión solicito asimismo que se proceda a la indemnización para los familiares de la víctima. Nicaragua ha realizado la declaración de aceptación de la jurisdicción contenciosa de la Corte Interamericana, el 12 de febrero de 1991.

La Corte Interamericana ha desestimado las excepciones preliminares interpuestas por el gobierno de Nicaragua en su sentencia del 27 de enero de 1995; y decidió posteriormente su conformación para entender en el fondo del asunto 320 (ver página siguiente) .

* Paniagua Morales y otros (Guatemala)

La Comisión Interamericana de Derechos Humanos introdujo este caso ante la Corte el 19 de enero de 1995, debido a hechos sucedidos en 1987 y 1988, cuando once civiles fueron supuestamente secuestrados, detenidos arbitrariamente, torturados y asesinados por parte de agentes de la Guardia de Hacienda de Guatemala.

La Corte Interamericana de Derechos Humanos, por sentencia del 25 de enero de 1996, desestimó las excepciones preliminares interpuestas por el gobierno 321 .

* Castillo Páez (Perú)

La Comisión Interamericana de Derechos Humanos interpuso este caso el 12 de enero de 1995, debido a que Ernesto Castillo Páez, estudiante, fue detenido por agentes de la Policía General el 21 de octubre de 1990, y posteriormente desaparecido; y solicitó a la Corte se condene a Perú por violaciones a los derechos a la vida, a la libertad personal, a la integridad personal, a las garantías judiciales y a la protección judicial.

La Corte Interamericana de Derechos Humanos decidió por sentencia del 30 de enero de 1996, desestimar las excepciones interpuestas por el gobierno, y continuar con la tramitación del fondo del asunto 322 .

El gobierno interpuso el 21 de marzo de 1996, un recurso de nulidad contra la sentencia de excepciones preliminares.

* Loayza Tamayo (Perú)

La Comisión Interamericana de Derechos Humanos envió este caso contra Perú para conocimiento de la Corte Interamericana, el 12 de enero de 1995.

El caso está originado en que el 6 de febrero de 1993, la profesora María Elena Loayza Tamayo fue arrestada por miembros de la División Nacional contra el Terrorismo de la Policía Nacional de Perú, sin orden judicial de arresto. La mencionada profesora estuvo veinte días detenida en la DINACOTE, diez de los cuales fueron bajo incomunicación, y fue objeto de torturas, tratos crueles y degradantes y apremios ilegales; luego ha sido trasladada hasta un centro penitenciario de máxima seguridad, donde se encontraba detenida hasta la fecha de la demanda presentada por la Comisión.

La Corte Interamericana, por sentencia de fecha 31 de enero de 1996 ha desestimado la excepción preliminar interpuesta por el gobierno 323 .

El gobierno elevó a la Corte el 21 de marzo de 1996, un recurso de nulidad contra la sentencia de excepciones preliminares. El Tribunal, por una resolución de fecha 27 de junio de 1996, decidió rechazarlo por improcedente. 
* Blake (Guatemala)

La Comisión Interamericana de Derechos Humanos llevó este asunto a la consideración de la Corte Interamericana de Derechos Humanos el 3 de agosto de 1995, por la detención el 28 de marzo de 1985 de Nicholas Chapman Blake, periodista, y Griffith Davis, fotógrafo, por parte de miembros de la Patrulla Civil de El Llano; quienes luego de interrogarles, les dieron muerte. En 1987 se dispuso la incineración de los restos de las dos víctimas para evitar que fueran descubiertos. En 1992 se hallaron los restos de ambas personas.

La Corte Interamericana, en su sentencia de excepciones preliminares del 2 de julio de 1996, decidió aceptar parcialmente la primera excepción interpuesta por Guatemala, y se declaró incompetente para decidir sobre la responsabilidad del Estado en lo que respecta a la detención y la muerte de ambas víctimas, debido a que la aceptación de la Competencia Contenciosa de la Corte por parte de Guatemala, fue realizada el 9 de marzo de 1987.

Asimismo, la Corte decidió rechazar por improcedentes las otras excepciones, y continuar con el conocimiento del caso, en relación con los efectos y los hechos ocurridos con posterioridad a la fecha en que Guatemala reconoció la competencia de la Corte 324 .

* Suárez Rosero (Ecuador)

Este asunto fue interpuesto por la Comisión Interamericana de Derechos Humanos a la Corte el 22 de diciembre de 1995; motivado por una supuesta detención arbitraria e ilegal ocurrida el 23 de junio de 1992 cuando agentes del Estado ecuatoriano, arrestaron al señor Rafael Suárez Rosero y le mantuvieron incomunicado durante 36 días, y procediendo luego al encarcelamiento del demandante hasta la misma fecha de presentación de la demanda por la Comisión, lo cual configura, a juicio de aquella, violaciones a los artículos 1.1, 2, 5, 7, 8 y 25 de la Convención Americana sobre Derechos Humanos 325.

* Benavides Cevallos (Ecuador)

La Comisión Interamericana sometió este caso, para que la Corte Interamericana tome conocimiento del mismo el 21 de marzo de 1996. La demanda se refiere a los hechos ocurridos a partir del 4 de diciembre de 1985, cuando la profesora Consuelo Benavides y el señor Serapio Ordoñez fueron detenidos por ocho hombres armados miembros de la Infantería Naval ecuatoriana, en la residencia de Ordoñez en la localidad de Quinindé. Luego, han sido interrogados y trasladados hasta una base militar en Esmeraldas. Posteriormente, han sido sometidos a torturas y malos tratos. Serapio Ordoñez fue puesto en libertad, y respecto a la profesora Benavides, no se supo más de su paradero hasta el mes de diciembre de 1988 en que fue encontrado su cuerpo sin vida.

La Comisión Interamericana de Derechos Humanos alega que el Estado de Ecuador, es responsable de la violación de los derechos a la libertad personal; del derecho de hábeas corpus y a la protección judicial; del derecho a la integridad corporal y a no ser sometido a torturas; del derecho a la vida; del derecho al reconocimiento de la personalidad jurídica; y de la negación de justicia a los familiares de la víctima.

La Corte conoció del caso durante su XIX Período Extraordinario de Sesiones, entre el 26 de junio y el 3 de julio de 1996326 .

* Cantoral Benavides (Perú)

La Comisión elevó este caso a la Corte el 8 de agosto de 1996, por la presunta privación de la libertad y sometimiento a tratos crueles inhumanos y degradantes, y violación de las garantías judiciales, en perjuicio del señor Cantoral Benavides.

La Corte conoció del caso en su XXXIV Período Ordinario de Sesiones, entre el 9 y el 20 de setiembre de 1996327 .

* Durand y Ugarte (Perú)

La Comisión puso este caso a conocimiento de la Corte Interamericana de Derechos Humanos el 8 de agosto de 1996, debido a la presunta detención de Nolberto Durand Ugarte y Gabriel Ugarte Rivera, bajo sospecha de haber participado en actos terroristas. Luego, fueron puestos en prisión en el Penal San Juan Bautista (El Frontón), los días 14 y 15 de febrero de 1986. 
En junio de 1986, se produjo un motín en dicho centro penitenciario y desde esa fecha ambas personas se encuentran desaparecidas. El 17 de julio de 1987, un Tribunal Correccional de Lima resolvió que ambos eran inocentes y ordenó su inmediata puesta en libertad.

La Comisión sostiene que el gobierno es responsable de violar el derecho a la vida, a la libertad personal, a las garantías judiciales, a la protección judicial y al régimen de suspensión de garantías establecido por la Convención Americana sobre Derechos Humanos, en perjuicio de ambas víctimas.

La Corte conoció del caso en su XXXIV Período Ordinario de Sesiones entre el 9 y el 20 de setiembre de 1996328 .

* Bámaca Velásquez (Guatemala)

Este caso fue sometido a la Corte a través de una demanda presentada por la Comisión Interamericana de Derechos Humanos el 30 de agosto de 1996, por la supuesta desaparición, torturas y ejecución de Efraín Bámaca Velásquez, cuando el 12 de marzo de 1992, la víctima habría sido capturada por las Fuerzas Armadas de Guatemala luego de un enfrentamiento armado, mantenido vivo en varias instalaciones militares donde fue torturado, y luego asesinado.

La Corte conoció del caso en su XXXIV Período Ordinario de Sesiones entre el 9 y el 20 de setiembre de 1996329 .

3.- Medidas provisionales dictadas por la Corte (mención)

A lo largo de su desempeño, la Corte Interamericana de Derechos Humanos ha dictado providencias sobre medidas provisionales en los siguientes asuntos:

* Velásquez Rodríguez / Honduras (1988)

* Godínez Cruz / Honduras (1988)

* Fairén Garbi y Solís Corrales / Honduras (1988)

* Caballero Delgado y Santana / Colombia (1994)

* Bustios Rojas / Perú (1990)

* Chunimá / Guatemala (1991)

* Reggiardo Tolosa / Argentina (1993)

* Colotenango / Guatemala (1994 - 1995 - 1996)

* Carpio Nicolle / Guatemala (1995 - 1996)

* Blake / Guatemala (1995)

* Alemán Lacayo / Nicaragua (1996)

* Vogt / Guatemala (1996)

* Serech y Saquic / Guatemala (1996)

* Loayza Tamayo / Perú (1996)

Asimismo, en los siguientes casos, la Corte Interamericana ha rechazado los pedidos de la Comisión Interamericana respecto a la aplicación de medidas provisionales.

* Penales peruanos / Perú (1992)

* Chipoco / Perú (1992) 


\title{
LOS POSTULADOS EMERGENTES DE LA JURISPRUDENCIA DE LA CORTE INTERAMERICANA: INTRODUCCION
}

\begin{abstract}
Sumario: I.- Introducción; II.- Postulados del Derecho Internacional general; III.- Postulados del Derecho Internacional de los Derechos Humanos; IV.- Postulados de creación pretoriana de la Corte Interamericana de Derechos Humanos; V.- Nuestra definición de Postulado. V.1.- Concepto; V.2.- Caracteres; V.3.- Otras consideraciones.
\end{abstract}

\section{I.- Introducción}

En los Capítulos II y III del presente trabajo, realizamos un marco descriptivo, de la evolución que ha sufrido el Derecho Internacional de los Derechos Humanos, sus características generales, sus relaciones y efectos sobre el Derecho Internacional Público, y algunos de sus institutos.

Asimismo, fueron objeto de análisis las Organizaciones Internacionales en las que se encuentran instaurados sistemas de protección de los derechos humanos, los mecanismos protectivos y sus características, y los tipos de órganos de protección que existen para los derechos y libertades fundamentales.

En el Capítulo anterior, hemos realizado una descripción de las competencias principales, y de la tarea jurisprudencial que ha desarrollado la Corte Interamericana de Derechos Humanos, desde que emitiera su primera Opinión Consultiva en 1982.

Los Capítulos que siguen llevan a un estudio profundo de la jurisprudencia emitida por la Corte Interamericana de Derechos Humanos, y las relaciones de esta jurisprudencia con el Derecho Internacional general y el Derecho Internacional de los Derechos Humanos, a los que nos hemos referido en los Capítulos II y III.

En el camino recorrido por la Corte Interamericana de Derechos Humanos a través de sus decisiones, se observa una jurisprudencia emergente que, en opinión de algunos autores «... ha contribuido a impulsar la evolución del Derecho Internacional de los derechos humanos en el ámbito regional y también en el general...» 330 (ver página siguiente) .

En igual dirección a la señalada en el párrafo anterior, decimos que la Corte Interamericana de Derechos Humanos ha resaltado ciertos Postulados, algunos de los cuales son de su propia autoría, y otros, los ha recogido de contenidos que posee el Derecho Internacional general, o de aspectos que pertenecen al Derecho Internacional de los Derechos Humanos propiamente dicho.

Dichos Postulados sobresalen en la jurisprudencia de la Corte Interamericana, ya bien por reiteración y desarrollo de los mismos, ya bien por la importancia que adquirieron para una mejor defensa de los derechos humanos en el continente americano.

Juan Antonio Travieso sostiene, en un libro dedicado a la tarea de la Corte, que «... En general, la Corte Interamericana de Derechos Humanos ha construido varios conceptos jurídicos por medio de la jurisprudencia estructurándose un esquema de interpretación que guarda coherencia en el conjunto...» 331

Barberis habla de la ambigüedad del término principio, y menciona que la expresión se utiliza para referirse «... a las características principales, a las propiedades fundamentales o a los rasgos más importantes de un orden jurídico, y se la usa también cuando alguien se refiere al propósito o 
fin perseguido por una ley..." El autor dice que en otros contextos jurídicos, se lo vincula con la idea de axioma, o proverbio que viene de la tradición jurídica 332 .

Los «principios», en otra de sus acepciones, constituyen institutos que dentro del Derecho Internacional Público han adquirido un valor sumamente importante, tanto cuando provienen del Derecho Internacional propiamente dicho, como cuando proceden del derecho interno, en tanto que fuentes del Derecho Internacional.

Luego de evaluar las dificultades que acarrea el término «principio» tanto en derecho interno como en Derecho Internacional, creemos más conveniente para nuestro trabajo la utilización de la palabra «Postulado».

Cuando en este trabajo se hable de «Postulados», debe entenderse que podemos referirnos a principios, o a ciertos enunciados que no alcanzan tal categoría en el derecho. Volveremos sobre nuestra definición de Postulado, en el acápite final de este Capítulo.

\section{II.- Postulados del Derecho Internacional general}

Como hemos enunciado anteriormente, existe una gran división doctrinaria sobre la definición y contenidos de los principios del Derecho Internacional; esta dificultad de conceptualización encuentra su origen en dos motivos básicos.

El primero de ellos está dado porque, como veremos más adelante, dentro de las fuentes del Derecho Internacional Público se encuentran los llamados principios generales del derecho, los cuales han sido utilizados por los tribunales arbitrales a lo largo del siglo XIX.

La segunda causa de la división doctrinaria, se observa en que dentro de las instituciones internacionales (en particular la Organización de las Naciones Unidas) se han desarrollado los llamados «principios del Derecho Internacional», que en algunos casos (citamos el ejemplo del principio de la buena fe) coinciden en nombre y, a veces en contenido, con los que se conocen como principios generales del derecho.

Fernando Mariño Menéndez, considera que deben diferenciarse dos sentidos de la expresión «principios generales del Derecho Internacional»; para dicho autor: «... De un lado están los principios entendidos como normas muy generales y abstractas que se encuentran en las normas consuetudinarias y convencionales de las que pueden ser extraídos por inducción y de cuya naturaleza participan. Lo más importante de ellos es que ya se han aplicado en la práctica de los Estados... De otra parte se ha planteado también la posibilidad de que ciertos principios generales del Derecho Internacional sirvan para fundar la formulación y aplicación judicial de normas por vía deductiva...». El autor menciona como ejemplos, a los principios reconocidos por la Resolución 2625 de la Asamblea General de las Naciones Unidas 333 .

Es decir, se infiere de lo dicho que los principios del Derecho Internacional, no se encuentran en un único instrumento, lo cual hace difícil establecer a ciencia cierta un estudio abarcativo de los mismos; en otro orden, los llamados principios del Derecho Internacional formarían parte de los cánones que determinan para los Estados y Organizaciones Internacionales el comportamiento a seguir en las relaciones internacionales contemporáneas.

Así parece entenderlo Eduardo Jiménez de Aréchaga, quien describe que «... La más notable innovación de la Carta de las Naciones Unidas, comparada con el Pacto de la Liga de las Naciones, es comenzar en su Capítulo I por una enumeración de Propósitos y Principios que constituyen, a la vez, obligaciones de conducta de los Estados miembros y reglas que rigen el funcionamiento de la propia Organización...» 334 .

Algunos principios del Derecho Internacional, como venimos viendo, han tenido su construcción a través del citado artículo 2 de la Carta de Naciones Unidas, y principalmente de la Resolución 2625, adoptada por la Asamblea General de la Organización. Esta última disposición lleva por título «Declaración sobre los principios del derecho internacional referentes a las relaciones de amistad y a la cooperación entre los Estados de conformidad con la Carta de las Naciones Unidas» 335 .

Estos principios son, según la citada declaración, la prohibición del uso o amenaza de la fuerza; la igualdad soberana de Estados; la libre determinación de los pueblos; el deber de no intervención; 
la solución pacífica de las controversias; la obligación de cooperación de los Estados entre sí; y el cumplimiento de buena fe de las obligaciones internacionales.

Asimismo, la Corte Internacional de Justicia (y su antecesora la Corte Permanente de Justicia Internacional) ha ido construyendo otros preceptos con su jurisprudencia, tal como el principio de la reparación integral, que será analizado en el capítulo siguiente, ya que es recogido por la jurisprudencia de la Corte Interamericana de Derechos Humanos.

El artículo 38 del Estatuto de la Corte Internacional de Justicia, contiene una enumeración de las fuentes del Derecho Internacional. Dicha norma establece que el Tribunal, cuya función es decidir conforme al Derecho Internacional, debe aplicar las convenciones, la costumbre, los principios generales del derecho «reconocidos por las naciones civilizadas», o la equidad, como fuentes principales, y la doctrina de los publicistas y la jurisprudencia, como fuentes auxiliares 336 .

Algunos autores, como Pastor Ridruejo, consideran que las únicas fuentes realmente autónomas del Derecho Internacional son la costumbre y los tratados; debido a que los principios generales del derecho «... constituyen una categoría normativa común a los derechos internos y al derecho internacional...» 337 .

En igual sentido Hans Kelsen cree que «... Probablemente, se supone que esos «principios generales del derecho» son la fuente suplementaria del derecho internacional, a aplicarse si las otras dos - tratado y costumbre - no pueden ser aplicadas...» 338 .

Juan Carlos Puig, analizando al vocablo «principios generales del derecho» del artículo 38 del Estatuto de la Corte Internacional de Justicia, señala que los contenidos de los mismos acarrean controversias, pero que de acuerdo al Comité Consultivo de Juristas que preparó el anteproyecto de Estatuto de la Corte Permanente de Justicia Internacional (luego adoptado por la Corte Internacional de Justicia) la expresión quería significar los principios fundamentales en que se asentaban los Derechos internos 339 .

Efectivamente, Fernando Mariño Menéndez comparte este criterio, y menciona que el artículo 38.1.c concibe principios generales de Derecho establecidos y aplicados en los ordenamientos estatales internos, y que, por otro lado, se trata de «... principios jurídicos aplicables en el orden jurídico internacional, es decir, en las relaciones entre sujetos internacionales y preferentemente entre Estados...» 340 .

En cuanto al párrafo «reconocidos por las naciones civilizadas» a que hace referencia la última parte del inciso 1.c del artículo 38 del Estatuto de la Corte Internacional de Justicia, Max Sorensen considera que se refiere a principios tan generales «... que se aplican dentro de todos los sistemas jurídicos que han logrado una etapa comparable de desarrollo...» 341 .

Pero la época en que fue concebido el Estatuto de la Corte Permanente de Justicia Internacional, nos hace pensar en una concepción eurocentrista del concepto «naciones civilizadas». Es interesante la opinión del profesor Carrillo Salcedo sobre el nuevo contenido de esta frase. Para dicho autor «... únicamente los Estados que respeten los derechos humanos fundamentales serían Estados civilizados, en los términos del artículo 38 del Estatuto de la Corte Internacional de Justicia, y Estados amantes de la paz, en los términos del artículo 4 de la Carta de las Naciones Unidas...» 342 .

Tal como señala Germán Bidart Campos, los principios generales del derecho tiene una importancia que no es poca para la resolución de asuntos jurídicos en disputa: «... en el caso de que no exista una norma expresa para resolver una cuestión determinada, los principios generales del derecho se convierten en un arsenal posible de solución para resolver ese caso y colmar la ausencia o el vacío de la norma inexistente; en este supuesto, tienen aplicación subsidiaria; pero no es este el único servicio que prestan...» 343 .

En lo que respecta al sistema interamericano, el marco de actuación de la Corte Interamericana, se toca en algunos aspectos con el ámbito de trabajo de la Corte Internacional de Justicia 344 ;

No obstante lo anterior, la propia especificidad de las cuestiones que resuelve la Corte Interamericana de Derechos Humanos, frente a la generalidad de asuntos (toda cuestión de Derecho Internacional), que puede llegar a la Corte de La Haya, hace que en el cuadro jurídico de protección de los derechos humanos en la Organización de los Estados Americanos, no encontremos una 
disposición sobre «fuentes del derecho», que sea similar al artículo 38 del Estatuto de la Corte Internacional de Justicia.

Claro que, lo anterior no significa que la Corte Interamericana posea libre albedrío para la aplicación de cualquier instrumento jurídico que crea conveniente, o decidir los asuntos conforme a su leal saber y entender.

En primer lugar, la Corte Interamericana de Derechos Humanos aplica la Convención Americana sobre Derechos Humanos; particularmente en su competencia contenciosa, ya que allí debe juzgar si el Estado acusado ha violado o no alguna disposición de dicho instrumento.

Así, el Pacto de San José de Costa Rica dice que la Corte Interamericana debe resolver «... cualquier caso relativo a la interpretación y aplicación de las disposiciones de esta Convención que le sea sometido siempre que los Estados partes en el caso hayan reconocido o reconozcan dicha competencia...» 345 .

Tal como señala Juan Carlos Hitters, debe tenerse presente que «... en el primer proyecto de Estatuto sometido a la Corte, ella tenía una competencia más amplia, ya que podía resolver cualquier controversia entre los Estados miembros de la OEA, empero como la Asamblea General definió este cuerpo como una «institución» y no como un «órgano», limitó estatutariamente su competencia y función a lo que específicamente lo faculta el Pacto de San José...» 346.

En los asuntos consultivos, la Corte Interamericana interpreta la propia Convención Americana sobre Derechos Humanos, $\mathrm{u}$ «otros tratados», comprendiéndose esta expresión, como la hemos desarrollado en el capítulo anterior 347 . Asimismo, el Tribunal está facultado para interpretar el grado de compatibilidad entre la legislación interna de los Estados y dichos instrumentos internacionales 348 .

Debemos diferenciar aquí, el hecho de que la Corte Interamericana de Derechos Humanos, cuando resuelve un caso en competencia contenciosa o contesta una consulta formulada por un órgano de la OEA o un Estado miembro de la Organización, aplica la Convención Americana de Derechos Humanos como tratado marco, pero para llegar a dicha aplicación, muchas veces interpreta normas distintas al Pacto de San José.

Conforme a lo señalado, y como analizaremos in extenso en el capítulo siguiente, es interesante destacar, que de la jurisprudencia seguida por la Corte Interamericana de Derechos Humanos en esta materia, puede inferirse que el criterio de utilización de fuentes, es el mismo que rige para la Corte Internacional de Justicia 349 .

En uno de sus casos contenciosos resueltos, (Aloeboetoe y otros contra Suriname), la Corte Interamericana ha hecho explícito este criterio. En dicha oportunidad sostuvo el Tribunal «... en el derecho de gentes no existe ninguna norma convencional ni consuetudinaria que determine quiénes son los sucesores de una persona. Por consiguiente, es preciso aplicar los principios generales del derecho (art. 38.1.c del Estatuto de la Corte Internacional de Justicia)...» 350 .

En cuanto a su función consultiva, tal como señala Espinal Arias, la Corte «... de un modo indubitado tiene potestad de resolver controversias aplicando o interpretando el derecho internacional vigente para los Estados Americanos...» 351 .

Tal como hemos visto en los dos párrafos anteriores, y como veremos en el capítulo siguiente, en las ocasiones que ha debido resolver casos contenciosos o emitir opiniones consultivas, la Corte Interamericana de Derechos Humanos ha seguido los criterios en cuanto a las fuentes del derecho, que están determinadas en el artículo 38 del Estatuto de la Corte Internacional de Justicia.

Naturalmente, cabe concluir que la relación de la Jurisprudencia de la Corte Interamericana con las normas del Derecho Internacional Público es obvia e innegable; siendo un tribunal internacional, no podría prescindir de ellas, máxime teniendo en cuenta la propia relación entre el Derecho Internacional Público y el Derecho Internacional de los Derechos Humanos 352.

Por ello, la remisión a la normativa del Derecho Internacional Público por parte de las decisiones de la Corte Interamericana, nos lleva a sostener que nos encontramos frente a una primera categoría, dentro de los Postulados analizados en el Capítulo siguiente.

Estos Postulados aplicados por la Corte Interamericana son emergentes propiamente del Derecho Internacional Público; ya sea en la aplicación de reglas convencionales, principios del Derecho 
Internacional, principios generales del derecho considerados fuentes del Derecho Internacional, resoluciones de órganos internacionales, o bien recogidos de la propia jurisprudencia de la Corte Internacional de Justicia o su antecesora, la Corte Permanente de Justicia Internacional.

Así, la Corte Interamericana ha considerado que los tratados de derechos humanos, deben interpretarse conforme al objeto y fin para el que han sido creados, adoptando con dicho criterio, las reglas de interpretación establecidas en el Derecho Internacional convencional 353.

También la Corte Interamericana de Derechos Humanos, considera vital y procedente el principio de seguridad jurídica en todo proceso donde se decida sobre los derechos y libertades fundamentales, tomando este principio general del derecho, y como tal, fuente del Derecho Internacional.

En la misma línea de adopción de los principios generales del derecho, que son considerados fuentes del Derecho Internacional, la Corte Interamericana de Derechos Humanos ha desarrollado y utilizado el principio de legalidad, y el principio «iura novit curia».

El axioma clásico del Derecho Internacional general, que señala que deben agotarse los recursos internos antes de acudir a la vía internacional (la llamada regla del agotamiento de los recursos internos), ha sido recogido por los instrumentos internacionales de los derechos humanos, conforme a la característica de subsidiariedad que posee el Derecho Internacional de los Derechos Humanos, y que hemos analizado en el Capítulo II.

La Corte Interamericana de Derechos Humanos, ha considerado en numerosas ocasiones el agotamiento de los recursos internos, sus modalidades, y las excepciones aplicables a casos de protección de los derechos humanos.

En cuanto a los llamados «principios del Derecho Internacional» tal como los hemos visto supra, la Corte Interamericana ha empleado en su tarea el principio de buena fe.

La Corte Interamericana ha recurrido a decisiones de otros tribunales internacionales (notablemente a la Corte Internacional de Justicia, la Corte Permanente de Justicia Internacional y el Tribunal Europeo de Derechos Humanos), y a la jurisprudencia arbitral para otros Postulados, generalmente de tipo procesal: citamos como ejemplo la amplitud del juez internacional en la valoración de la prueba.

Hay otras consideraciones que pudieron incluirse en el Capítulo siguiente, que también surgen de la jurisprudencia de la Corte Interamericana de Derechos Humanos: citamos como ejemplo la afirmación del Tribunal que tiene su sede en San José de Costa Rica, en el sentido de que en Derecho Internacional y, particularmente aplicable a la Convención Americana sobre Derechos Humanos, la «justa indemnización» es de tipo compensatorio y no sancionatorio 354 .

En relación a lo anterior, creímos más procedente analizar el derecho a una reparación adecuada derivado del daño producido por la infracción de una norma de Derecho Internacional, como un Postulado tomado por la Corte Interamericana del Derecho Internacional Público general (en el Capítulo siguiente), y ciertas particularidades indemnizatorias como integrantes de un Postulado de creación pretoriana de la Corte Interamericana (en el Capítulo VIII).

\section{III.- Postulados del Derecho Internacional de los Derechos Humanos}

Tal como hemos visto en el tercer Capítulo, el Derecho Internacional de los Derechos Humanos propiamente dicho ha tenido su desarrollo principal a partir del fin de la segunda guerra mundial; este desarrollo, se acrecienta con el paso del tiempo, dándole al Derecho Internacional de los Derechos Humanos la característica de «progresividad» 355.

Sin entrar a considerar la autonomía del Derecho Internacional de los Derechos Humanos, las vinculaciones entre éste y el Derecho Internacional general son innegables: el Derecho Internacional de los Derechos Humanos es hoy una parte troncal del Derecho Internacional Contemporáneo. Pero la expansión y riqueza del actual Derecho Internacional de los Derechos Humanos, nos habla de una disciplina con caracteres propios 356 .

Algunos autores consideran que la cantidad de instrumentos jurídicos e instituciones internacionales creadas al efecto de proteger los derechos humanos ha construido y configurado «... un corpus iuris con fisonomía propia dentro del derecho internacional contemporáneo...» 357 . 
Pero esta autonomía a la que nos venimos refiriendo no significa exclusión, tal como veremos en seguida. En el acápite anterior del presente Capítulo hemos hecho referencia a los «principios del Derecho Internacional» y la consideración de algunos doctrinarios sobre el contenido de los mismos.

De allí que algunos de sus axiomas principales, sean a la vez principios del Derecho Internacional general. Citamos como ejemplo el principio de libre determinación de los pueblos, con contenidos claros de derechos humanos, ya que nace de la necesidad de poner fin al colonialismo 358 .

La resolución 1514 de la Asamblea General de las Naciones Unidas, que consagra el derecho a la libre determinación de los pueblos dice expresamente en su primer párrafo que «... los pueblos del mundo han proclamado en la Carta de las Naciones Unidas que están resueltos a reafirmar la fe en los derechos fundamentales del hombre, en la dignidad y el valor de la persona humana...» 359; y declaró que «... la sujeción de pueblos a una subyugación, dominación y explotación extranjeras constituye una denegación de los derechos humanos fundamentales...» 360 .

Similares disposiciones se recogen en la Resolución 2625 de la Asamblea General de las Naciones Unidas, que trata, como hemos visto en el punto anterior, específicamente de los principios del Derecho Internacional.

Incorporamos, entonces, como algunos Postulados emergentes de la jurisprudencia de la Corte Interamericana, ciertas máximas propias del Derecho Internacional de los Derechos Humanos, que han nacido del Derecho Internacional Público. La característica diferencial con otras normas de similar carácter, es que su principal objeto, está destinado a la protección de los derechos y libertades fundamentales de la persona; el principio de libre determinación de los pueblos, es un claro ejemplo.

Pero también existen algunos Postulados surgidos de la labor de la Corte Interamericana, que nacen en el Derecho Internacional de los Derechos Humanos, y se conforman por las características particulares de la disciplina, y de sus instrumentos jurídicos de protección.

Carlos Villán Durán considera que existen tres principios generales sobre los que se ha desarrollado el Derecho Internacional de los Derechos Humanos: «... Desde una perspectiva material el Derecho Internacional de los Derechos Humanos, que reconoce como su fundamento la dignidad intrínseca del ser humano, se ha construido en torno a tres pilares principales íntimamente ligados a la idea de dignidad, y que a su vez constituyen los principios básicos del ordenamiento que, por tanto, han inspirado todos los desarrollos normativos posteriores del mismo. Se trata de los principios de libertad, igualdad y solidaridad...» 361 .

Juan Carlos Hitters menciona, entre otros, como principios generales del Derecho Internacional de los Derechos Humanos, la no discriminación, la autodeterminación de los pueblos, y el principio de la legitimación del individuo para peticionar ante los foros internacionales 362 .

Las normas propias del Derecho Internacional de los Derechos Humanos son recogidas, ya sea en el espíritu o en la letra, por casi todo el bagaje jurisprudencial de la Corte Interamericana de Derechos Humanos, tal como veremos más adelante (fundamentalmente en el Capítulo VII).

De la primer categoría de Postulados señalados en este acápite (aquellos que pertenecen al Derecho Internacional Público con objeto central dirigido al Derecho Internacional de los Derechos Humanos), analizamos la jurisprudencia de la Corte Interamericana respecto al llamado «principio de no discriminación» $\mathbf{3 6 3}$.

De la segunda categoría de Postulados señalados en este acápite (aquellos que pertenecen al Derecho Internacional de los Derechos Humanos propiamente dichos), tomamos dos que se refieren a los instrumentos jurídicos de protección y uno que puede considerarse la máxima regla de la materia.

Los primeros consideran a la identidad particular de los instrumentos de protección de los derechos humanos, y se enuncian en dos oraciones que expresan respectivamente que: "los tratados de derechos humanos tienen una naturaleza propia, disímil de los tratados comunes en el Derecho Internacional" 364 ; y "las declaraciones marco de derechos humanos son jurídicamente obligatorias 
cuando constituyen la interpretación de los derechos humanos contenidos en los tratados constitutivos de las Organizaciones Internacionales" 365 .

En cuanto al principio que nos hemos referido como la norma máxima de la materia, es el conocido como la regla «pro homine», es decir, que toda interpretación en la aplicación de normativa de derechos humanos debe hacerse en favor de la persona humana 366 .

\section{IV.- Postulados de creación pretoriana de la Corte Interamericana de Derechos Humanos}

La Corte Interamericana de Derechos Humanos, como venimos viendo, ha tenido que hacer uso durante los años que lleva trabajando, de una jurisprudencia que se ha apoyado en diversos instrumentos jurídicos (de Derecho Internacional Público o específicamente de derechos humanos), de opiniones doctrinarias o de la jurisprudencia de otros tribunales internacionales, arbitrales y jurisdiccionales.

Pero las propias características de algunos casos que le ha tocado resolver, han exigido de la Corte Interamericana de Derechos Humanos la creación de directrices, para cumplir su cometido de proteger los derechos humanos consagrados en el Pacto de San José de Costa Rica, y dentro de una interpretación extensa de la Convención marco que le dio nacimiento.

Es así, que a los dos tipos de Postulados que hemos definido en los acápites anteriores y que son objeto de desarrollo en los Capítulos VI y VII, en cuanto a la aplicación jurisprudencial que de ellos ha hecho la Corte Interamericana de Derechos Humanos, debemos agregar una tercer categoría de Postulados, que surgen del estudio de la jurisprudencia llevada a cabo por el máximo órgano jurisdiccional de derechos humanos en el continente americano.

Dichos Postulados tienen la característica diferencial de ser creación propia de la Corte Interamericana de Derechos Humanos, es decir configuran una verdadera creación pretoriana del tribunal con sede en San José de Costa Rica.

Los escogidos para su enunciación y análisis jurisprudencial son los siguientes: «El ámbito de la función consultiva de la Corte Interamericana es el más amplio posible, dentro de los límites establecidos por la Convención Americana sobre Derechos Humanos»; "Cuando se dan ciertos requisitos, la Comisión debería considerar especialmente, la posibilidad de llevar un caso contencioso ante la Corte Interamericana»; «La desaparición forzada de personas, es una forma compleja de violación de varios derechos fundamentales»; y «Los hijos menores de víctimas de violaciones al derecho a la vida, deben tener asegurado especialmente su derecho a la educación» 367 .

\section{V.- Nuestra definición de Postulado}

Hemos elegido para la presente publicación, sólo algunos de los Postulados emergentes de la jurisprudencia de la Corte Interamericana de Derechos Humanos; simplemente aquellos que consideramos más trascendentes, y de acuerdo con el desarrollo que hemos hecho en los Capítulos precedentes.

Es decir, la jurisprudencia seleccionada de los Capítulos siguientes, tienen que ver con alguno de aquellos aspectos que hemos jerarquizado del Derecho Internacional general, del Derecho Internacional de los Derechos Humanos, de sus órganos de protección, y de las características y funcionamiento de los mismos.

Naturalmente, cabe señalar que no pretendemos agotar el examen de estos axiomas o líneas jurisprudenciales derivados de la tarea desarrollada por la Corte Interamericana de Derechos Humanos, sino destacar sus características más importantes, surgidas de una selección realizada conforme a determinados criterios, que exponemos en los dos puntos siguientes.

\section{1.- Concepto}

Como paso necesario para la entrada de lleno al análisis de las decisiones de la Corte Interamericana, sobre lo que llamamos «Postulados emergentes de la jurisprudencia del tribunal», corresponde que definamos que entendemos por Postulado. 
A los efectos del presente trabajo, entendemos por Postulado emergente de la jurisprudencia de la Corte Interamericana de Derechos Humanos, un enunciado expreso o implícito que surge de las decisiones tomadas por dicho tribunal, y que configuren una línea de pensamiento substancial para la protección de los derechos humanos.

Estos enunciados pueden ser expresos o implícitos, incluso surgir de la propia actitud tomada por la Corte en un proceso.

\section{2.- Caracteres}

El criterio tomado para la selección, ha sido destacar a los Postulados emergentes de la jurisprudencia de la Corte Interamericana de Derechos Humanos, teniendo en cuenta dos posibilidades:

a) La reiteración de párrafos en varias decisiones, que refuerzan un concepto que la Corte Interamericana, sin duda, ha querido jerarquizar 368 ; o

b) Aunque sólo se trate de una decisión de la Corte Interamericana que sostenga el Postulado escogido, se tiene en cuenta la importancia para la protección de los derechos humanos que aquel revista; es decir, su fuerza en relación a los derechos y libertades fundamentales 369 .

\section{3.- Otras consideraciones}

Finalmente, hemos prestado mayor importancia a la jurisprudencia de la Corte Interamericana en opiniones consultivas, las sentencias sobre el fondo de casos contenciosos, y sentencias sobre reparaciones, en la determinación de las indemnizaciones y reparaciones correspondientes a la resolución de estos últimos.

Las sentencias de excepciones preliminares respecto de casos contenciosos también se han considerado, analizado y sistematizado para el presente; debido a que tienen una jurisprudencia tan rica como las sentencias de fondo, $\mathrm{y}$, en algunos casos, han dado fin al procedimiento, de manera total (caso Cayara) 370 , o parcial (caso Blake) 371 .

Por último, en cuanto al tipo de resoluciones que toma la Corte Interamericana de Derechos Humanos, las medidas provisionales adoptadas por el Tribunal no han sido objeto de nuestro análisis.

Quisiéramos, finalmente, realizar unas consideraciones sobre la clasificación que hemos elaborado, y respecto al marco en el cual la Corte Interamericana de Derechos Humanos ha construido su jurisprudencia.

Hemos visto que, el Derecho Internacional de los Derechos Humanos asimila y recoge máximas del Derecho Internacional general, adecuándolos a la particularidad del tema, (por ejemplo la regla del agotamiento de los recursos internos).

De aquí que, verbigracia, el Postulado que enuncia «las restricciones a los derechos deben hacerse respetando el principio de legalidad» (principio general del derecho que, como hemos visto, ha sido tomado como fuente del Derecho Internacional), puede considerarse en el Sistema Interamericano, propio del Derecho Internacional de los Derechos Humanos, a la luz de los artículos de la Convención Americana sobre Derechos Humanos que tratan la restricción de derechos y la suspensión de garantías, de acuerdo a la jurisprudencia de la Corte Interamericana de Derechos Humanos 372 .

En otro orden, aunque un Postulado sea calificado por nosotros «de creación pretoriana de la Corte Interamericana», al aplicarse a un caso puntual de derechos humanos pasa, obviamente, a formar parte del Derecho Internacional de los Derechos Humanos, y como tal, con vinculaciones directas con el Derecho Internacional general.

Es decir, que todos los Postulados escogidos aqui, que surgen de la jurisprudencia de la Corte Interamericana de Derechos Humanos, pueden considerarse válidamente parte integrante del Derecho Internacional de los Derechos Humanos.

Naturalmente, el marco legal del trabajo de la Corte Interamericana de Derechos Humanos está dado, como hemos visto, principalmente en el Capítulo IV, por el llamado «Pacto de San José de Costa Rica». 
Pues bien, la jurisprudencia de la Corte Interamericana de Derechos Humanos se ha basado, como hemos definido anteriormente, en las obligaciones contraidas por los Estados miembros de la Organización de los Estados Americanos en virtud de la Carta constitutiva de la OEA, y del artículo 1 de la Convención Americana, en cuanto estipula que «... Los Estados Partes en esta Convención se comprometen a respetar los derechos y libertades reconocidos en ella y a garantizar su libre y pleno ejercicio a toda persona que esté sujeta a su jurisdicción...» 373 .

Con las previsiones mencionadas, entonces, los tres Capítulos siguientes, desarrollan los Postulados emergentes de la jurisprudencia de la Corte Interamericana de Derechos Humanos, que hemos escogido, tomados del Derecho Internacional general, del Derecho Internacional de los Derechos Humanos, o de la propia creación pretoriana del Tribunal. 


\title{
LA JURISPRUDENCIA DE LA CORTE INTERAMERICANA: POSTULADOS TOMADOS DEL DERECHO INTERNACIONAL GENERAL
}

\begin{abstract}
Sumario: I.- Introducción; II.- Postulados tomados del Derecho Internacional general; II.1.- Los métodos de interpretación que utiliza la Corte Interamericana, son los mismos que posee el Derecho Internacional general; II.2.- Las restricciones a los derechos, deben hacerse respetando el principio de legalidad; II.3.Para el acceso a la vía internacional del Sistema Interamericano de Derechos Humanos, debe procederse al agotamiento de los recursos internos; II.4.- Los procedimientos del Sistema Interamericano de Derechos Humanos, deben llevarse adelante bajo el respeto al principio de seguridad jurídica; II.5.- Los Estados deben respetar y aplicar el principio de buena fe; II.6.- Los tribunales internacionales poseen amplia libertad para evaluar los medios de prueba, sin sujetarse a parámetros estrictos; II.7.- El juez conoce el derecho: «iura novit curia»; II.8.- En materia de derechos humanos, rige el principio de continuidad del Estado; II.9.- El daño producido por la violación de una norma de Derecho Internacional, engendra el derecho a una reparación adecuada.
\end{abstract}

\section{I.- Introducción}

Este Capítulo recoge nueve enunciados que se desprenden de la práctica jurisprudencial de la Corte Interamericana de Derechos en sus dos competencias principales, consultiva y contenciosa.

Todos tienen la característica común de ser contenidos del Derecho Internacional Público, aunque con distintas jerarquías dentro del «derecho de gentes».

En efecto, algunos de ellos forman parte de principios del derecho interno que adquieren la categoría de fuente del Derecho Internacional, (por ejemplo, aquel que se refiere a la seguridad jurídica); otros, por el contrario, encuentran su cuna en el ámbito internacional propiamente dicho (por ejemplo el que hace referencia al principio de continuidad del Estado).

En la aplicación de las normas internacionales por parte de la Corte Interamericana de Derechos Humanos (conforme a las fuentes del derecho), el Tribunal ha seguido sin dudas y fielmente, el método establecido en el Estatuto de la Corte Internacional de Justicia.

Así, en un particular caso donde no había registros que establecieran la identidad y los sucesores de personas que habían sufrido violación a varios derechos contemplados en la Convención Americana sobre Derechos Humanos, la Corte ha dicho que «... El Convenio N 169 de la O.I.T. sobre pueblos indígenas y tribales en países independientes (1989) no ha sido aprobado por Suriname y en el derecho de gentes no existe ninguna norma convencional ni consuetudinaria que determine quiénes son los sucesores de una persona. Por consiguiente, es preciso aplicar los principios generales del derecho (art. 38.1.c. del Estatuto de la Corte Internacional de Justicia)...» 374 .

Volviendo a los Postulados escogidos, ellos fueron adecuados por la Corte Interamericana de Derechos Humanos, en la medida que ha sido necesario para el sistema interamericano, considerando la particularidad de los asuntos que han llegado al seno del Tribunal para ser resueltos. 
El primero de los Postulados que tratamos en el presente Capítulo, se refiere a los métodos de interpretación del Derecho Internacional Público.

La Corte Interamericana ha recogido y aplicado para su tarea, las disposiciones del Derecho Internacional convencional en la materia, que se encuentran contenidas en la Convención de Viena sobre Derecho de los Tratados.

El segundo Postulado se refiere a un típico principio que utiliza el Derecho Internacional, cuyas fuentes provienen del derecho interno: la legalidad.

La Corte Interamericana lo ha adecuado a las necesidades y exigencias del Derecho Internacional de los Derechos Humanos, y lo aplicó concretamente, al régimen de suspensión de garantías previsto en la Convención Americana.

El tercer Postulado que hemos elegido para analizar, se refiere a una regla tradicional del Derecho Internacional Público; aquella que enuncia que antes de acudir a una instancia internacional, deben agotarse los recursos de jurisdicción interna.

Al igual que en el caso anterior, y teniendo en cuenta que el no agotamiento de los recursos internos, es una excepción de invocación permanente por los Estados cuando son parte demandada en un caso contencioso ante la Corte Interamericana, el Tribunal ha adecuado la regla al Derecho Internacional de los Derechos Humanos, basándose en la interpretación y desarrollo de las normas pertinentes, establecidas en la Convención Americana sobre Derechos Humanos.

El cuarto Postulado también remite al derecho interno y es tomado por la jurisprudencia como fuente del Derecho Internacional; se aplica a casos contenciosos y, en general, a todo mecanismo o procedimiento donde exista una parte acusada: se trata de la aplicación del principio de seguridad jurídica.

La Corte Interamericana de Derechos Humanos ha hecho uso de este principio, haciéndolo jugar en combinación a la flexibilidad de formas que rige para el Derecho Internacional, y al principio "pro homine", propio del Derecho Internacional de los Derechos Humanos.

El quinto Postulado que estudiaremos, se refiere a un principio existente, tanto en el derecho interno, como en el Derecho Internacional, ya que rige plenamente en materia convencional (contratos y tratados, respectivamente): se trata de la buena fe en el cumplimiento de las obligaciones contraías.

La Corte Interamericana ha subrayado este principio, teniendo en cuenta la importancia de las convenciones sobre derechos humanos y sus particularidades (que serán analizadas en el capítulo siguiente); y finalmente lo aplica al comportamiento de los Estados, relacionándolo con otro de los principios del Derecho Internacional general que no forma parte de un acápite especial del presente: la preclusión (o regla del stoppell).

El sexto Postulado a estudiar es una regla de tipo práctico, aplicada a la valoración de las pruebas por parte de los tribunales internacionales. En estas instancias, hay muchas menos formalidades que en el derecho interno.

Este Postulado tiene su importancia, ya que los instrumentos probatorios son de difícil hallazgo en un caso de derechos humanos, y mucho más en el tipo de casos que llegan a tratamiento de la Corte Interamericana de Derechos Humanos (piénsese, por ejemplo, en el temor de quiénes deben prestar testimonio contra un gobierno ante un tribunal internacional y deben seguir habitando en el mismo lugar, o la falta y ocultamiento de pruebas que existe en casos de desaparición forzada).

No obstante, esta flexibilidad debe ser mirada en conjunto con el principio de seguridad jurídica al que también nos referimos en el presente capítulo.

El séptimo Postulado escogido para el análisis es un viejo principio del derecho procesal en general, y aplicable al derecho procesal penal en particular: aquel que dice que el juez no se ata al pedido de la parte sino que aplica el derecho en virtud de conocerlo: «iura novit curia».

La Corte Interamericana de Derechos Humanos ha hecho uso de este principio, respecto de los pedidos que le ha formulado la Comisión Interamericana en cuanto a formulación de consultas y en casos contenciosos. 
El octavo Postulado elegido para su estudio, deviene directamente del Derecho Internacional clásico general: se trata de la continuidad del Estado en relación a la responsabilidad, en un caso por violaciones a los derechos humanos.

Este principio de derecho clásico adquiere fuera del marco de la Organización de los Estados Americanos, una trascendencia inusitada en el Derecho Internacional actual; debido a la formación de nuevos Estados, a partir de los conflictos que han eclosionado con posterioridad a la caída del muro de Berlín.

En la Corte Interamericana de Derechos Humanos, se aplica en otra de sus posibilidades. A pesar de los cambios de gobiernos, la responsabilidad derivada de violaciones a los derechos humanos corresponde al Estado (más allá de la posible responsabilidad penal para los casos de crímenes de lesa humanidad que hemos visto en el Capítulo II).

Por último, el noveno Postulado se toma de un instituto troncal del derecho de gentes, la responsabilidad internacional. Consiste en el derecho a una reparación adecuada, derivado del daño generado, por la violación producida a una norma de Derecho Internacional.

La Corte Interamericana de Derechos Humanos ha desarrollado de una manera muy interesante este criterio; aplicando luego pretorianamente el concepto de reparación integral y dando contenido al mismo. Aquí evaluaremos el derecho a la reparación adecuada; en cuanto al último punto (lo que tiene que ver con la "reparación integral" para el Tribunal), lo tratamos en el Capítulo octavo del presente trabajo.

\section{II.- Postulados tomados del Derecho Internacional general}

Seguidamente, enunciaremos y analizaremos los nueve Postulados que hemos escogido, y a los que hemos hecho referencia en el acápite anterior, a la luz de la jurisprudencia de la Corte Interamericana de Derechos Humanos.

\section{1.- Los métodos de interpretación que utiliza la Corte Interamericana, son los mismos que posee el Derecho Internacional general}

Las formas de interpretación de los instrumentos jurídicos principales del Derecho Internacional, es decir de los tratados, se encuentran contenidas en la llamada Convención de Viena sobre Derecho de los Tratados 375 .

Citando a la Comisión de Derecho Internacional cuando ésta preparó el proyecto de artículos que sirvió de base a la Convención de Viena, Pastor Ridruejo dice que «... la interpretación de tratados es hasta cierto punto un arte, no una ciencia exacta, pese a lo cual redactó [ la Comisión de Derecho Internacional ] un número relativamente pequeño de reglas que parecen constituir el fundamento general de la interpretación de los tratados...» 376 .

La Corte Interamericana de Derechos Humanos, en la primera Opinión Consultiva que le ha sido sometida debió abordar la cuestión, y ya remite expresamente en su decisión, a las disposiciones pertinentes de la Convención de Viena sobre Derecho de los Tratados, como regla a seguir en su actuación.

En este sentido, El Tribunal dijo que: «... Para la interpretación del artículo 64 de la Convención la Corte utilizará los métodos tradicionales del Derecho Internacional, tanto en lo que se refiere a las reglas generales de interpretación, como en lo que toca a los medios complementarios, en los términos en que los mismos han sido recogidos por los artículos 31 y 32 de la Convención de Viena sobre el Derecho de los Tratados...» 377 .

También, tratando la situación de el hábeas corpus bajo suspensión de garantías, la Corte Interamericana insistió con el Postulado que sostenemos. «... La interpretación de los artículos 25.1 y 7.6 de la Convención con respecto a la posibilidad de suspender el hábeas corpus en los estados de excepción, frente a lo dispuesto en el artículo 27.2, debe hacerse utilizando las normas de la Convención de Viena sobre el Derecho de los Tratados, que pueden considerarse reglas de derecho internacional general sobre el tema...» 378 .

¿Cuáles son los métodos tradicionales a los que alude la decisión de la Corte que hemos mencionado? Podestá Costa y Ruda sostienen que según la Convención de Viena que rige en la 
materia, para interpretar un tratado, en primer lugar debe recurrirse a un criterio exegético: «... el texto es la manifestación auténtica de la intención de las partes y de que, por consiguiente, el punto de partida de la interpretación consiste en elucidar el sentido del texto y no en investigar ab initio la intención de las partes...» 379 .

En el caso Caballero Delgado y Santana contra Colombia, debiendo interpretar el término "recomendaciones" conforme a las facultades de la Comisión Interamericana de Derechos Humanos, la Corte ha dicho que «... debe ser interpretado conforme a su sentido corriente de acuerdo con la regla general de interpretación contenida en el artículo 31.1 de la Convención de Viena sobre Derecho de los Tratados...» 380 (ver página siguiente) .

La alusión a la regla del sentido corriente como forma inicial de interpretar un texto, y el significado de la expresión «sentido corriente», ha sido tratado por la Corte Internacional de Justicia (órgano judicial de las Naciones Unidas) en los casos relativos a la admisión de nuevos miembros en las Naciones Unidas, asuntos del sudoeste africano (excepción preliminar), sentencia del asunto al laudo arbitral de 31 de julio de 1989 (Guinea Bissau c/ Senegal), asunto de la Anglo Iranian Oil Company, y sentencia en el asunto de la Plataforma Continental del Mar Egeo 381 .

Teniendo que analizar el término «plazo», para determinar si un caso había sido presentado dentro del término establecido por la Convención Americana sobre Derechos Humanos, la Corte Interamericana ha sostenido que «... La expresión «plazo de tres meses» debe entenderse en su sentido usual. de acuerdo con el Diccionario de la Real Academia de la Lengua Española, «plazo» [es el] término o tiempo señalado para una cosa», y «mes» [es el] número de días consecutivos desde uno señalado hasta otro de igual fecha en el mes siguiente». Asimismo, la Convención de Viena sobre el Derecho de los Tratados (artículo 31.1) enumera entre los elementos de interpretación, el sentido corriente de las palabras, además del contexto, objeto y fin del tratado...» 382 .

Algunas veces, el Tribunal interamericano de derechos humanos, del cual nos encontramos analizando su jurisprudencia, ha debido conjugar interpretaciones diferentes del Pacto de San José de Costa Rica. En estos casos, tampoco se ha apartado de la regla general de interpretación mencionada.

En efecto, la Corte Interamericana de Derechos Humanos, interpretando reservas a la Convención Americana en materia de pena de muerte, sostuvo que «... La forma como está planteada la consulta hace necesario precisar el sentido y alcance de las disposiciones del artículo 4 de la Convención, en especial de sus párrafos 2 y 4 , y las posibles conexiones que guardan éstos entre sí, de las cuales dependerá la posibilidad de relacionar el efecto de la reserva al uno con el texto del otro. Para hacerlo la Corte utilizará los criterios de interpretación consagrados en la Convención de Viena, que pueden considerarse reglas del derecho internacional general sobre el tema...» 383 .

Pero este criterio interpretativo general tomado por la Corte Interamericana, ha sido adecuado tratándose de la aplicación de la Convención Americana sobre Derechos Humanos, ya que el Tribunal ha hecho hincapié permanente en la interpretación, sin dejar de tener en consideración el objeto y fin de la misma.

Rafael Nieto Navia, citando a la jurisprudencia de la Corte Interamericana de Derechos Humanos, destaca un párrafo de la misma que señaló: «... La interpretación hay que hacerla en forma tal que no conduzca de manera alguna a debilitar el sistema de protección consagrado en la Convención, y siempre teniendo en cuenta que el objeto y fin de la misma son la protección de los derechos fundamentales de los seres humanos...» 384 .

La Corte Interamericana ha insistido en el criterio expuesto en varios casos contenciosos; citamos como ejemplo el siguiente párrafo «... Para hacerlo [ la Corte ] deberá ratificar su criterio tantas veces expresado de que el objeto y fin del tratado es la protección de los derechos humanos y que a él hay que subordinar la interpretación de todas las disposiciones del mismo, como lo dispone la Convención de Viena sobre el Derecho de los Tratados en su artículo 31...» 385 . 
La interpretación conforme al objeto y fin toma en consideración el llamado criterio teleológico, el cual postula que los términos de un tratado no pueden ser interpretados in abstracto, sino considerando el objetivo perseguido por las partes contratantes.

En materia de derechos humanos este criterio es fundamental, ya que otorga al objeto y fin del tratado una jerarquía que, si bien no puede ir contra lo literalmente expreso, tampoco puede desentenderse en virtud de una interpretación meramente exegética. La Corte Internacional de Justicia ha aplicado este concepto en la Opinión Consultiva sobre reservas a la Convención contra el Genocidio 386 .

Así pareció haberlo entendido efectivamente la Corte Interamericana, cuando dispuso que: «... hasta que punto puede el artículo 75 ayudar a resolver la pregunta planteada a la Corte, es algo que solamente es posible contestar después de un análisis de esa disposición, así como de otras pertinentes de la Convención, en su contexto, así como del objeto y fin de la misma (ver Convención de Viena, artículo 31), y en su caso, por referencia a los trabajos preparatorios (Convención de Viena, artículo 32)...» 387 .

Sobre los trabajos preparatorios, éstos forman parte de un medio de interpretación que es complementario, según la Convención de Viena sobre Derecho de los Tratados: «... Se podrá recurrir a medios de interpretación complementarios, en particular a los trabajos preparatorios del tratado...» 388 .

La Corte Interamericana de Derechos Humanos también ha recogido la validez de los trabajos preparatorios como métodos de interpretación complementarios, y de acuerdo a lo establecido en la Convención de Viena.

En este sentido, el Tribunal sostuvo que: «... Los trabajos preparatorios de la Convención confirman el sentido resultante de la interpretación hecha, conforme a los términos del artículo 64, dentro de su contexto, y teniendo en cuenta su objeto y su fin. Dichos trabajos pueden, pues, ser utilizados como medio de interpretación complementaria, según prevé el artículo 32 de la Convención de Viena sobre Derecho de los Tratados...» 389.

Podemos sostener, como consecuencia de lo hasta aquí analizado, que la Convención de Viena sobre Derecho de los Tratados, en materia de interpretación de estos instrumentos sigue un criterio coherente y equilibrado, haciendo jugar conjuntamente los criterios de interpretación literal y teleológica. Dentro de este interjuego, la interpretación literal tiene preeminencia sobre la teleológica.

En cuanto a los trabajos preparatorios, forman parte de una ayuda para la interpretación, pero tienen el valor de complementarios.

De la jurisprudencia de la Corte Interamericana analizada, podemos decir que ha seguido el criterio de la Convención de Viena en materia de interpretación, aunque reforzando la indisolubilidad del texto con el objeto y fin, en virtud de la particularidad que ofrece un tratado de derechos humanos.

Este concepto, ha sido sostenido claramente cuando la Corte debió interpretar el artículo 30 de la Convención Americana sobre Derechos Humanos, en el marco de la suspensión de garantías prevista por el capítulo IV del Pacto de San José de Costa Rica.

En dicha ocasión, la Corte Interamericana sostuvo que «... La interpretación de esta norma ha de hacerse de buena fe, conforme al sentido corriente que ha de atribuirse a los términos empleados por el tratado en su contexto, y teniendo en cuenta su objeto y fin (art. 31 de la Convención de Viena sobre Derecho de los Tratados)...» 390 (ver página siguiente) .

\section{2.- Las restricciones a los derechos, deben hacerse respetando el principio de legalidad}

Ya hemos visto que entre las fuentes del Derecho Internacional Público, contendidas básicamente en el artículo 38 del Estatuto de la Corte Internacional de Justicia, se encuentran los principios generales de derecho 391 .

No cualquier principio general del derecho interno puede ser considerado por la Corte Internacional de Justicia como fuente del derecho; debe tratarse de axiomas aceptados por un conjunto de Estados, y no característicos de uno solo de ellos. 
El principio de legalidad establece que en un Estado de derecho, la juridización se realiza sólo por medio de la norma pensada, creada y consagrada de acuerdo a los pasos constitucionales propios de una sociedad democrática.

Este principio de legalidad, se encuentra en numerosos preceptos constitucionales del mundo, y particularmente del continente americano; por lo cual cabe concebirlo como un principio general del derecho que reúne las características de fuente del Derecho Internacional de acuerdo con el Estatuto de la Corte Internacional de Justicia.

No ha pasado este hecho desapercibido para la Corte Interamericana de Derechos Humanos; la cual, en su sexta Opinión Consultiva, menciona la aplicación que la Corte Permanente de Justicia Internacional ha hecho del principio de legalidad. Efectivamente, el tribunal antecesor de la Corte Internacional de Justicia, ha tomado este principio en su Opinión Consultiva «Consistency of Certain Danzig Legislative Decrees with the Constitution of the Free City» 392.

Volvemos ahora a las condiciones de ejercicio del principio de legalidad. Conforme lo dicho en los tres primeros párrafos del presente acápite, sólo es posible su desenvolvimiento en un régimen democrático de gobierno.

La Corte Interamericana de Derechos Humanos, ha hecho uso del principio de legalidad, aplicado a la protección de los derechos humanos, en el marco del Pacto de San José de Costa Rica.

En tal sentido, el Tribunal expresó reiteradamente en varias Opiniones Consultivas que «... el principio de legalidad, las instituciones democráticas y el Estado de Derecho son inseparables...» 393.

En el sistema interamericano, el concepto de democracia es consubstancial a la protección de los derechos humanos en el continente.

Nieto Navia destaca la estrecha vinculación existente, entre los derechos fundamentales de la persona y el ejercicio efectivo de la democracia representativa, dentro de la Convención Americana sobre Derechos Humanos 394.

La Corte Interamericana de Derechos Humanos, ha relacionado la idea de que el principio de legalidad sólo puede funcionar en una democracia efectiva, y dice respecto de aquel que «... es consubstancial con la idea y el desarrollo del derecho en el mundo democrático y que tiene como corolario la aceptación de la llamada reserva de ley, de acuerdo con la cual los derechos fundamentales sólo pueden ser restringidos por ley, en cuanto expresión legítima de la voluntad de la nación...» 395 .

No cabe eludir aquí, la consideración de que la Corte Interamericana de Derechos Humanos, ha utilizado el principio de legalidad como sostenimiento del principio «pro homine», que se desarrolla en el capítulo siguiente 396 .

En ese sentido, la Corte Interamericana mencionó que «... los criterios del artículo 30 sí resultan aplicables a todos aquellos casos en que la expresión ley o locuciones equivalentes son empleadas por la Convención a propósito de las restricciones que ella misma autoriza respecto de cada uno de los derechos protegidos...» 397 .

Es decir, la Corte Interamericana de Derechos Humanos, ha generalizado el principio de legalidad, no sólo para la restricción del artículo treinta de la Convención Americana, sino también para todos los asuntos similares.

Asistimos en el Derecho Internacional Contemporáneo, a una conjunción de los conceptos de democracia, desarrollo y derechos humanos, aspectos que ya hemos analizado en el Capítulo II.

El sistema interamericano de derechos humanos no escapa a esta concepción, y evoluciona en una tendencia dirigida hacia la profundización de dicha relación.

De esta forma, tal como sostiene Cançado Trindade en un análisis sobre democracia y derechos humanos «... No deja de ser significativo que el sistema interamericano disponga actualmente de un mecanismo para asegurar el principio de la legitimidad democrática en conexión con la observancia de los derechos humanos...» 398 .

Para terminar con el presente acápite, vemos como la Corte Interamericana de Derechos Humanos ha sostenido el principio de legalidad, lo ha relacionado con el sistema democrático, y lo 
ha aplicado en favor del principio «pro homine», en torno a las limitaciones al ejercicio de los derechos humanos.

La Corte Interamericana de Derechos Humanos sostuvo que en materia de restricción de derechos, la palabra "ley" se utiliza en el sentido formal de la misma, y la define textualmente como «... norma jurídica de carácter general, ceñida al bien común, emanada de los órganos legislativos constitucionalmente previstos y democráticamente elegidos, y elaborada según el procedimiento establecido por las constituciones de los Estados Partes para la formación de las leyes...» 399 .

\section{3.- Para el acceso a la vía internacional del Sistema Interamericano de Derechos Humanos, debe procederse al agotamiento de los recursos internos}

Existe en el Derecho Internacional general, la exigencia de agotar los recursos internos antes de llevar adelante un procedimiento internacional; este requisito se encuentra elevado a la categoría de principio.

Afirma Cançado Trindade, que «... es un principio clásico de derecho internacional que la responsabilidad internacional de un Estado por daños causados a extranjeros sólo puede ser implementada a nivel internacional después de agotados los recursos de derecho interno por los individuos en cuestión, esto es, después de que el Estado reclamado tenga válidamente la oportunidad de reparar los supuestos daños por sus propios medios y en el ámbito de su ordenamiento jurídico interno. Las raíces históricas en la larga evolución de esa regla, como comúnmente es entendida hoy, se remontan a la antigua práctica de represalias...» (traducción no oficial que hemos realizado de la versión portuguesa) 400 .

El reconocimiento de que el agotamiento de los recursos internos es un principio del Derecho Internacional, lo encontramos en la misma letra de la Convención Americana sobre Derechos Humanos, cuyo artículo 46, postula como uno de los requisitos para la admisión de comunicaciones individuales, que «... se hayan interpuesto y agotado los recursos de jurisdicción interna, conforme a los principios del Derecho Internacional generalmente reconocidos...» 401 .

Tal como hemos mencionado en el Capítulo II, al analizar las características de la protección internacional de los derechos humanos, la subsidiariedad encuentra su aplicación con la regla del agotamiento previo de los recursos internos.

La relación de la regla del agotamiento de los recursos internos con el principio de subsidiariedad, ha sido destacada por la Corte Interamericana en varias oportunidades.

Así, el Tribunal dispuso que «... La regla del previo agotamiento de los recursos internos permite al Estado resolver el problema según su derecho interno antes de verse enfrentado a un proceso internacional, lo cual es especialmente válido en la jurisdicción internacional de los derechos humanos, por ser esta «coadyuvante o complementaria» de la interna (Convención Americana, Preámbulo)...» 402 .

Cecilia Medina, ha señalado que «... El sistema de control de las violaciones aisladas tiene como una de sus premisas el que los Estados en los que los tratados internacionales están vigentes, estén sometidos al imperio de la ley: que sean Estados de derecho. De manera ideal, el sistema de protección de los derechos humanos opera - en primer lugar - dentro del Estado y esto no sólo por la existencia de recursos efectivos para reparar posibles violaciones, sino que también por la existencia de una red preventiva de las violaciones, constituida por todas las instituciones propias de un Estado de Derecho...» 403 .

En igual dirección, la Corte sostuvo que es deber de los Estados partes de la Convención Americana «... organizar todo el aparato gubernamental y, en general, todas las estructuras a través de las cuales se manifiesta el ejercicio del poder público, de manera tal que sean capaces de asegurar jurídicamente el libre y pleno ejercicio de los derechos humanos...» 404 .

La regla del agotamiento de los recursos internos, juega un papel medular en relación a la protección de los derechos y libertades fundamentales. La Corte Interamericana de Derechos Humanos, ha sostenido este principio del Derecho Internacional, pero le ha dotado de precisión, a los efectos de que la misma, no pueda ser utilizada como un arma en favor de la impunidad de los 
gobiernos. Así, poco a poco, la jurisprudencia tanto consultiva como contenciosa del Tribunal de San José, llevó a determinar los límites y excepciones a dicho principio.

La Corte, se ha tomado en primer lugar de lo establecido en la propia Convención Americana de Derechos Humanos, es decir, la no exigencia del cumplimiento de la regla, cuando dichos recursos no existan, cuando el peticionario haya sido impedido de acceder a los recursos o de agotarlos, o exista un retardo injustificado en la decisión sobre los mismos. Estos requisitos, en palabras de Héctor Gros Espiell, constituyen una expresión de lo que al respecto reconocen los principios del Derecho Internacional generalmente reconocidos 405 .

Como interpretación de ello, la Corte ha estimado que «... debe tenerse presente que es norma de derecho internacional y correlativo lógico de la obligación de agotar los recursos internos, que dicha regla no se aplica cuando no hay recursos que agotar...» 406 .

De esta forma, el Tribunal comenzó a delinear las características que los recursos internos deben poseer, para que la excepción de no agotamiento sea interpuesta con éxito por los Estados: los recursos internos deben, en primer lugar, existir; y además ser adecuados y efectivos.

Sosteniendo la regla general, hemos dicho que «... el agotamiento de los recursos internos no es exigible si en la legislación doméstica no existen estos recursos, o si no pudo accederse a los mismos, o si hubo imposibilidad de agotarlos, o si el Estado incurre en una demora injustificada en la resolución de los mismos...» 407 .

La Corte Interamericana, determinó que cuando en un caso «... se demuestra que los recursos son rechazados sin llegar al examen de la validez de los mismos, o por razones fútiles, o si se comprueba la existencia de una práctica o política ordenada o tolerada por el poder público, cuyo efecto es el de impedir a ciertos demandantes la utilización de los recursos internos que, normalmente, estarían al alcance de los demás... el acudir a esos recursos se convierte en una formalidad que carece de sentido. Las excepciones del art. 46.2 serán plenamente aplicables en estas situaciones y eximirían de la necesidad de agotar los recursos internos que, en la práctica, no pueden alcanzar su objeto...» 408 .

También existe un límite en cuanto al momento en que la regla de no agotamiento de los recursos internos puede oponerse por los Estados. La excepción, debe ser invocada oportunamente en el trámite ante la Comisión Interamericana; en este caso, algunos autores hablan de renuncia tácita a oponer la excepción 409 .

En igual dirección, la Corte Interamericana ha dicho que «... La Corte observa que el Gobierno no hizo valer ante la Comisión la excepción de no agotamiento de los recursos internos - hecho que fue expresamente confirmado por el agente en la audiencia pública del 2 de diciembre de 1991 - lo que constituye una renuncia tácita a la excepción...» 410 .

Algunos autores, hablan de la aplicación para este supuesto, de la regla del "estoppel". Esta regla ha sido definida por Pastor Ridruejo de la siguiente forma: «... según el Derecho Internacional un Estado está obligado por sus propios actos, habida cuenta de la obligación general de obrar de buena fe y del correspondiente derecho de otros Estados de fiarse de la conducta del primero...» 411

La Corte Interamericana de Derechos Humanos, ha dicho que la invocación del no agotamiento de los recursos internos puede ser renunciada en forma expresa o tácita por el Estado demandado 412 .

En otro asunto, un voto razonado de Cançado Trindade en un caso contra Perú, ha mencionado expresamente el principio del "estoppel", que la Corte Interamericana ha aplicado a los Estados, cuando estos han perdido la oportunidad de oponer la excepción de no agotamiento de los recursos internos.

En dicha oportunidad consideró el Juez brasileño: «... El gobierno demandado se encuentra impedido de interponer dicha excepción preliminar posteriormente ante la Corte, por no haberla opuesto, en su debido momento, para la decisión de la Comisión. Si, por la no presentación de aquella excepción in límine litis, tal renuncia a la misma ocurrió en el procedimiento previo ante la Comisión, como en el presente caso, es inconcebible que el Gobierno demandado pueda libremente retirar esa renuncia en el procedimiento subsiguiente ante la Corte (estoppel / forclusión)...» 413 . 
Si tratamos de realizar un ordenamiento del Postulado al que hacemos referencia, sostenido por la Corte Interamericana de Derechos Humanos, podemos señalar que de acuerdo al principio de subsidiariedad, deben agotarse los recursos internos antes de llegar a la vía internacional en materia de violaciones a los derechos humanos.

Además, los recursos internos deben ser proporcionados adecuadamente por el Estado, es decir, existir y cumplir los objetivos para los cuales han sido creados.

Como ha dicho la Corte Interamericana de Derechos Humanos, en una Opinión Consultiva específica sobre el agotamiento de los recursos internos: «... como lo señalan los principios generales del Derecho Internacional aplicables como lo exige el artículo 46.1, es decir, idóneos para proteger la situación jurídica infringida y capaces de producir el resultado para el que fueron concebidos...» 414 .

La oportunidad procesal de oponer la excepción de no agotamiento de los recursos internos, es en el momento de contestar la comunicación en el trámite frente a la Comisión Interamericana de Derechos Humanos.

La regla de no agotamiento de los recursos internos, se entiende renunciable por parte de los Estados; esta renuncia puede ser expresa o tácita.

Por último, tal como ha dicho la Corte Interamericana, si un Estado alega el no agotamiento de los recursos internos debe probarlo. 415 .

La práctica de la Corte Interamericana ha sido, aunque el no agotamiento de los recursos internos se oponga como excepción, resolverla junto al fondo del asunto 416 . Aunque es probable que en el futuro este criterio cambie.

\section{4.- Los procedimientos del Sistema Interamericano de Derechos Humanos, deben llevarse adelante bajo el respeto al principio de seguridad jurídica}

El Derecho Internacional Público, tiene como una de sus características, que los sujetos fundamentales y los principales destinatarios de sus normas, son Estados soberanos.

La soberanía Estatal, aunque ha adquirido nuevos contornos, como hemos visto en el Capítulo II, sigue siendo uno de los principios básicos del Derecho Internacional Contemporáneo.

Tal como sostiene Carrillo Salcedo «... la soberanía estatal, principio constitucional del orden internacional, no ha sido desplazada por el desarrollo del fenómeno de Organización Internacional ni por los derechos humanos en tanto que nuevo principio constitucional del derecho internacional, aunque sí erosionada y relativizada...» 417 .

De allí que cuando el Derecho Internacional trata de juzgar comportamientos estatales, y más aún, sancionarlos cuando son contrarios a derecho, encuentre generalmente una mayor resistencia, a diferencia de si esto sucediera dentro de las fronteras del Estado en cuestión, porque se considera, aunque en rigor de verdad no lo sea, una «posible lesión a la soberanía nacional».

Una manifestación clara de dicha soberanía de los Estados, se encuentra en las cláusulas opcionales de los tratados de derechos humanos, que facultan a aquellos, a aceptar voluntariamente procedimientos en su contra 418 .

Las jurisdicciones contenciosas internacionales que se conocen (nos referimos a la Corte Internacional de Justicia 419 , el Tribunal Europeo de Derechos Humanos 420 y la Corte Interamericana de Derechos Humanos 421 (ver página siguiente) ) tienen como condición previa para llevar un caso contra un Estado, la aceptación de dicha posibilidad a través de un acto que es facultativo para éstos.

Entonces, un requisito imprescindible para que los Estados se sometan voluntariamente a un sistema donde se les vigile su comportamiento en materia de derechos humanos, es que ese sistema sea transparente, con límites precisos, y que garantice la imparcialidad en la tramitación de asuntos.

Dicho en otras palabras, el mecanismo de protección de derechos humanos debe ser confiable para Estados, y naturalmente, también para los peticionarios.

La Corte tuvo un caso contencioso donde el principio de seguridad jurídica, tuvo que ser confrontado con una realidad penosa en materia de derechos humanos. 
Efectivamente, el Tribunal, en ejercicio de su función contenciosa, debió conocer de un asunto en el cual se encontraban probadas en el trámite ante la Comisión Interamericana, detenciones arbitrarias, torturas, ejecuciones extrajudiciales, desaparición forzada de personas y daños contra la propiedad. Posteriormente, fueron asesinados durante el año siguiente, todos los testigos de la masacre. Los hechos mencionados, han sido imputados al ejército de Perú.

La Comisión ya se había manifestado condenando a Perú, pero interpuso el caso ante la Corte con graves deficiencias de procedimiento (fuera de plazo, lo retiró, y volvió a presentarlo vencido el plazo por segunda vez).

La sentencia de la corte hizo lugar a la excepción de Perú, por considerar que la Comisión Interamericana había interpuesto su demanda fuera del plazo fijado 422 .

Algunos prestigiosos estudiosos del sistema interamericano han criticado duramente el hecho: «... La Corte que «a primera vista» consideró atendibles los argumentos de la Comisión para retirar el caso, no otorga ningún valor a la actividad desplegada en el expediente durante los siete meses que median entre el retiro del caso y la presentación de la nueva demanda, y concluye, en último análisis, que el retiro no es justificado simplemente porque el Estado no lo requirió. En el contexto de una petición en cuyo trámite se respetaron substancialmente las oportunidades de las partes para exponer sus posiciones, el Tribunal llega a una decisión que, basada en un riguroso formalismo, pierde de vista la protección de las víctimas...» 423 .

Pero la Corte Interamericana, ha hecho valer el principio de seguridad jurídica en sus fundamentos: «... La Corte debe guardar un justo equilibrio entre la seguridad jurídica y equidad procesal que aseguran la estabilidad y confiabilidad de la tutela internacional. En el caso sub judice continuar con un proceso enderezado a lograr la protección de los intereses de las supuestas víctimas, estando de por medio infracciones manifiestas a las reglas procedimentales establecidas en la propia Convención, acarrearía la pérdida de la autoridad y credibilidad indispensables en los órganos encargados de administrar el sistema de protección de derechos humanos...» 424 .

Hemos visto anteriormente en este Capítulo, que las formalidades para la tramitación de un caso en el Derecho Internacional, son menos exigentes que en el derecho interno, si bien ello no implica la ausencia de formalidades.

Así, la Corte Interamericana de Derechos Humanos también tiene en cuenta, que debe existir una conjugación entre el no apegarse a un formalismo extremo, y la regla de la seguridad jurídica: «... Lo esencial es que se preserven las condiciones necesarias para que los derechos procesales de las partes no sean disminuidos o desequilibrados, y para que se alcancen los fines para los cuales han sido diseñados los distintos procedimientos...» 425 .

En el acápite anterior hemos analizado in extenso la regla del agotamiento de los recursos internos, y los principios que rigen en cuanto a la carga de la prueba, que el Tribunal ha hecho pesar sobre el Estado que alega la excepción.

En las tres primeras sentencias sobre el fondo, la Corte Interamericana subraya la importancia de equilibrar el proceso en virtud de la seguridad jurídica; y, aunque reconociendo la desigualdad entre un Estado y una presunta víctima de violaciones a los derechos humanos, considerando que si un Estado alega la excepción de no agotamiento de recursos internos, a él le compete la carga de la prueba; pero también que «... si el Estado que alega el no agotamiento prueba la existencia de determinados recursos internos que deberían haberse utilizado, corresponderá a la parte contraria demostrar que esos recursos fueron agotados o que el caso cae dentro de las excepciones del artículo 46.2. No se debe presumir con ligereza que un Estado Parte en la Convención ha incumplido con su obligación de proporcionar recursos internos eficaces...» 426 .

También en ejercicio de su función consultiva, la Corte Interamericana se refirió a la seguridad jurídica, analizando los requisitos de admisibilidad de una petición ante la Comisión Interamericana de Derechos Humanos: «... Los requisitos de admisibilidad tienen que ver, obviamente, con la certeza jurídica tanto en el orden interno como en el internacional. Sin caer en un formalismo rígido que desvirtúe el propósito y el objeto de la Convención, es necesario para los Estados y para los órganos de la Convención cumplir con las disposiciones que regulan el procedimiento, pues en ella descansa la seguridad jurídica de las partes...» 427 
La Corte ha vuelto sobre la seguridad jurídica en otros casos contenciosos, reiterando la jurisprudencia del caso Cayara, aunque en los asuntos en cuestión decidió rechazar las excepciones preliminares planteadas por los gobiernos: en este sentido señaló que «... es un principio comúnmente aceptado que el sistema procesal es un medio para realizar la justicia y que ésta no puede ser sacrificada en aras de meras formalidades, dentro de ciertos límites de temporalidad y razonabilidad, ciertas omisiones o retrasos en la observancia de los procedimientos, pueden ser dispensados, si se conserva un adecuado equilibrio entre la justicia y la seguridad jurídica...» 428 .

Finalmente, como límite a la falta de cumplimiento de los requisitos por parte de la Comisión Interamericana, subrayó que «... Debe la Corte, sin embargo, puntualizar que no existe razón alguna para que la Comisión no dé estricto cumplimiento a las normas procesales porque, como ha dicho ya y lo reitera ahora, es verdad que el objeto y fin de la Convención no pueden sacrificarse al procedimiento pero éste, en aras de la seguridad jurídica, obliga a la Comisión 429 .

En materia de protección a los derechos humanos, se conjugan y confrontan la interpretación de las normas y la actuación de los órganos de protección, en el sentido más favorable a las víctimas (principio pro homine), y sin dejar de considerar la seguridad jurídica indispensable para tener un sistema, que sea confiable a quiénes se someten voluntariamente al mismo.

La Corte Interamericana de Derechos Humanos ha intentado armonizar ambos criterios en sus resoluciones, pero puede decirse que, al menos en la decisión tomada en el caso Cayara, el Tribunal ha optado, en nombre de la seguridad jurídica y del respeto a la formalidad, por dejar de lado la regla «pro homine».

\section{5.- EI Los Estados deben respetar y aplicar el principio de buena fe}

La convivencia civilizada, requiere del acatamiento de determinadas reglas de comportamiento, por parte de los Estados en el manejo de sus relaciones internacionales.

El principio de buena fe ya estaba contemplado en la Carta de la Organización de las Naciones Unidas; dicho instrumento establece que «... Los miembros de la Organización, a fin de asegurarse los derechos y beneficios inherentes a su condición de tales, cumplirán de buena fe las obligaciones contraidas por ellos de conformidad con esta Carta...» 430 .

Ya hemos hecho referencia, en el capítulo anterior, a que algunos de esos principios fueron ampliados por la Resolución 2625 de la Asamblea General de las Naciones Unidas. Tal como claramente señala Jiménez de Aréchaga, esta decisión adoptada por la Asamblea General «... identifica los siete principios fundamentales del derecho internacional que surgen del Capítulo I de la Carta y codifica en forma detallada sus más importantes corolarios...» 431 .

Pues bien, la norma citada desarrolla el principio de buena fe mencionado en la Carta, y le otorga contenido, al estipular que se deben cumplir las obligaciones contraidas en virtud de los principios y normas de Derecho Internacional generalmente reconocidos, y los contraídos en virtud de acuerdos internacionales válidos 432 .

No cabe duda que los tratados de derechos humanos, si bien dotados de características particulares (como veremos en los capítulos posteriores), son acuerdos internacionales válidos, y los Estados que han contraído obligaciones en virtud de la ratificación o adhesión a los mismos, deben cumplir estas obligaciones de buena fe.

Así, la Corte Interamericana de Derechos Humanos ha mencionado que «... Según el derecho internacional las obligaciones que éste impone deben ser cumplidas de buena fe y no puede invocarse para su incumplimiento el derecho interno. Estas reglas pueden ser consideradas como principios generales del derecho y han sido aplicadas, aun tratándose de disposiciones de carácter constitucional, por la Corte Internacional de Justicia...» 433 .

Esta valoración de la Corte Interamericana de Derechos Humanos recoge una máxima del Derecho Internacional convencional, la cual establece que quiénes voluntariamente, y en ejercicio de su voluntad soberana, se someten a una determinada norma internacional, tienen luego la obligación de cumplirla. Derivadas de ella, las normas de interpretación de los tratados contenidas en la Convención de Viena de 1969 (que hemos tratado in extenso anteriormente), determinan como regla general de interpretación, que «... Un tratado deberá interpretarse de buena fe...» 434 . 
Pero el principio de buena fe en la jurisprudencia de la Corte Interamericana, no se refiere únicamente a la práctica de las obligaciones internacionales por parte de los Estados, sino también al comportamiento que éstos deben observar en un litigio por violaciones a los derechos humanos.

La Corte Interamericana de Derechos Humanos no sólo ha considerado que los Estados deben cumplir de buena fe sus obligaciones internacionales en virtud de la Convención Americana de Derechos Humanos, sino que ha ido más allá en el cumplimiento de este principio. El tribunal sostuvo que la abstención de un Estado en realizar acciones que le competían en virtud del Pacto de San José, también puede significar una infracción de la Convención, comportando esta inacción, una inobservancia de las obligaciones contraídas por aquel.

Podemos inferir lo anterior del siguiente párrafo, transcrito en varias de las opiniones consultivas y casos contenciosos resueltos: «... Son muchas las maneras como un Estado puede violar un tratado internacional y, específicamente, la Convención. En este último caso, puede hacerlo, por ejemplo, omitiendo dictar las normas a que está obligado por el artículo 2. También, por supuesto, dictando disposiciones que no estén en conformidad con lo que de él exigen sus obligaciones dentro de la Convención...» 435 .

Nos hemos referido al principio del estoppel en el primer Postulado analizado en el presente capítulo. Allí examinamos la relación que percibe la Corte Interamericana, entre dicha regla y el principio de buena fe 436 .

La Corte Interamericana de Derechos Humanos mencionó que conforme al principio de buena fe «... tampoco puede el Perú, como lo sostuvo en la audiencia, afirmar que la Comisión no tenía competencia para otorgar una prórroga al plazo de tres meses que él mismo pidió, pues, en virtud de la buena fe, no se puede solicitar algo de otro y, una vez obtenido lo solicitado, impugnar la competencia de quien se lo otorgó...» 437 ; y también que «... cuando una parte solicita algo, así sea fundada en una disposición inaplicable, no puede luego de que se lo concedan impugnar la fundamentación...» 438 .

Como vemos, el principio de buena fe tal como se entiende en el Derecho Internacional, ha sido aplicado por la jurisprudencia de la Corte Interamericana de Derechos Humanos, sin mayores modificaciones a su contenido.

\section{6.- Los tribunales internacionales poseen amplia libertad para evaluar los medios de prueba, sin sujetarse a parámetros estrictos}

Los medios de prueba en el derecho nacional, se encuentran regidos por normas estrictas, en procesos donde el Juez posee un marco de apreciación con límites rígidos, en buena medida en beneficio de la seguridad jurídica de los justiciables. Es decir, se acotan los márgenes de discrecionalidad de la administración de justicia, para prevenir la comisión de decisiones arbitrarias.

En el ámbito internacional, los tribunales se enfrentan a medios de prueba similares a los existentes en el derecho interno: así, peritos y especialistas técnicos, testigos, documentos, normas jurídicas, jurisprudencia anterior, etc., son elementos de los que se valen tanto el juzgador nacional como el internacional.

Pero a diferencia del derecho interno, en los casos tramitados dentro de la esfera internacional (tanto a nivel jurisdiccional como arbitral), los encargados de administrar justicia han sostenido un criterio más autónomo y libre para la valoración de los medios probatorios.

La Corte Interamericana de Derechos Humanos ha recogido esta máxima del Derecho Internacional general, al sostener que «... la jurisprudencia internacional ha sostenido la potestad de los tribunales para evaluar libremente las pruebas, aunque ha evitado siempre suministrar una rígida determinación del quantum de la prueba para fundar el fallo (cfr. Corfu Channel, Merits, Judgment, I.C.J. Reports, 1949; Military and Paramilitary Activities in and against Nicaragua (Nicaragua vs. United States of America), Merits, Judgment, I.C.J., Reports 1986, párrs. 29-30 y 59-60...» 439 .

En cuanto a las diferencias entre los ámbitos internacional e interno en la materia, la Corte Interamericana de Derechos Humanos mencionó que «... Para un tribunal internacional, los criterios de valoración de la prueba son menos formales que en los sistemas legales internos...» 440 . 
Este razonamiento posee una validez lógica en un proceso por derechos humanos, ya que este se encuentra munido generalmente de características muy particulares. Piénsese, por ejemplo, en los casos en que un Estado no coopera con el tribunal en la recepción de las pruebas, para intentar eludir la responsabilidad que podría competerle 441 .

Los casos sobre desaparición forzada de personas muestran la complejidad de la recepción de pruebas: muchas veces no hay registros ni documentos sobre la detención, los testigos también han sufrido desaparición o no prestan testimonio por temor, la víctima no aparece ni su cuerpo tampoco; de aquí que en este tipo de asuntos, una prueba como la indiciaria adquiera un valor fundamental.

Así lo ha hecho saber la Corte Interamericana en la resolución de los casos hondureños: «... La práctica de los tribunales internacionales e internos demuestra que la prueba directa, ya sea testimonial o documental, no es la única que puede legítimamente considerarse para fundar la sentencia...»; y también que: «... La prueba indiciaria o presuntiva resulta de especial importancia cuando se trata de denuncias sobre la desaparición, ya que esta forma de represión se caracteriza por procurar la supresión de todo elemento que permita comprobar el secuestro, el paradero y la suerte de las víctimas...» 442 .

El Tribunal ha hecho referencia a la prueba indiciaria, incluso en un caso de violación de derechos humanos que no se trataba de desaparición forzada de personas: «... La Corte, en ejercicio de su función jurisdiccional, tratándose de la obtención y valoración de las pruebas necesarias para la decisión de los casos que conoce puede, en determinadas circunstancias, utilizar tanto las pruebas circunstanciales como los indicios o las presunciones como base de sus pronunciamientos, cuando de aquellas puedan inferirse conclusiones consistentes sobre los hechos, en particular cuando el Estado demandado haya asumido una conducta renuente en sus actuaciones ante la Corte...» 443 .

\section{7.- El juez conoce el derecho: «iura novit curia»}

Este Postulado ha sido señalado expresamente dos veces por la Corte Interamericana de Derechos Humanos, en el ejercicio de su jurisprudencia contenciosa.

El mismo remite a un principio del derecho procesal que, en el ámbito internacional, tiene su máxima aplicación en las decisiones del juzgador conforme a la equidad (según su leal saber y entender), máxima que se ha aplicado a numerosos casos de arbitraje en el Derecho Internacional clásico, y que la propia Corte Internacional de Justicia puede utilizar, de acuerdo a su Estatuto de funcionamiento, que establece «... La presente disposición no restringe la facultad de la Corte para decidir un litigio ex aequo et bono, si las partes así lo deciden...» 444 .

En materia de derechos fundamentales, la amplitud del juzgador para valorar las pruebas (a la cual nos hemos referido en el acápite anterior), y para aplicar las normas más allá de su invocación por las partes, es medular para el cumplimiento de los objetivos, que les son encargados a los órganos de supervisión por los instrumentos internacionales de derechos humanos.

Así, como la misma Corte Interamericana lo ha reconocido, el Tribunal Europeo de Derechos Humanos también ha utilizado el principio «iura novit curia» en sus decisiones y sentencias.

La aplicación del Postulado por la Corte Interamericana de Derechos Humanos y la importancia que el tribunal da al mismo, se desprende directamente del presente párrafo de dos de sus sentencias: «... La Comisión no señaló de manera expresa la violación del artículo 1.1 de la Convención, pero ello no impide que sea aplicado por esta Corte, debido a que dicho precepto constituye el fundamento genérico de la protección de los derechos reconocidos por la Convención y porque sería aplicable, de todos modos, en virtud de un principio general del derecho, iura novit curia, del cual se ha valido reiteradamente la jurisprudencia internacional en el sentido de que el juzgador posee la facultad e inclusive el deber de aplicar las disposiciones jurídicas pertinentes en una causa, aun cuando las partes no las invoquen expresamente («Lotus», Judgment N 9, 1927, P.C.I.J., Series A, N 10, pág. 31 y Eur. Court H.R., Handyside Case, Judgment of 7 December 1976, Series A N 24, párr. 41)...» 445 (ver página siguiente).

\section{8.- En materia de derechos humanos, rige el principio de continuidad del Estado}


Los tribunales internacionales permanentes de derechos humanos que existen hasta el momento, juzgan Estados y no gobiernos, gobernantes o individuos 446 . Relacionado con esta cuestión, la Corte Interamericana de Derechos Humanos ha dicho que «... En lo que concierne a los derechos humanos protegidos por la Convención, la competencia de los órganos establecidos por ella se refiere exclusivamente a la responsabilidad internacional del Estado y no a la de los individuos...» 447 .

Pero no podemos dejar de señalar, la importancia de comenzar a tratar estos temas en el ámbito interamericano «... De seguro hace no muchas décadas ni siquiera se soñaba con un tribunal de derechos humanos por ante el cual se juzgue a los Estados, fenómeno ya común en Europa y América y que, no muy tarde, el resto de las regiones del mundo tendrán que imitar. No debe temerse a la ampliación de las esferas de competencia en materia de derechos humanos ni deben reputarse inalcanzables; es hora de ponerse a debatir seriamente en el continente sobre la cuestión de la responsabilidad individual en materia de violaciones a los derechos humanos. La solicitud que derivó en la Opinión Consultiva $\mathrm{N} 14$ ha dado un inicial pero trascendente paso en la materia...» 448 .

De acuerdo a los tiempos que genera un proceso de derechos humanos antes de llegar a una sentencia de la Corte Interamericana sobre el fondo del asunto, suele suceder que el gobierno que comparece al trámite final (y a veces al principio del asunto), no sea el mismo que ha cometido la violación motivo de la acusación (téngase en cuenta que un proceso normal, lleva en la jurisdicción interna el agotamiento de los recursos procedentes, y luego se desarrolla el asunto ante la comisión, envío del caso a la Corte, trámite ante la misma, decisión sobre excepciones preliminares, recepción de la prueba, etc.; y a ello debemos agregarle el hecho de que la Corte de San José no funciona de manera permanente, sino sólo en sesiones algunas veces al año).

En Derecho Internacional Público, los hechos ilícitos punibles generan responsabilidad para el Estado más allá de los cambios de gobierno: en éste sentido, la Corte Interamericana de Derechos Humanos ha dicho que toda violación de los derechos humanos por agentes o funcionarios de un Estado, es responsabilidad ineludible de éste 449.

El Tribunal ha hecho referencia concreta al Postulado que examinamos aquí: «... Según el principio de derecho internacional de la identidad o continuidad del Estado, la responsabilidad subsiste con independencia de los cambios de gobierno en el transcurso del tiempo y, concretamente, entre el momento en que se comete el hecho ilícito que genera la responsabilidad y aquel en que ella es declarada...» 450 .

\section{9.- El daño producido por la violación de una norma de Derecho Internacional, engendra el derecho a una reparación adecuada}

Todo ordenamiento jurídico posee mecanismos de identificación y sanción de las infracciones al mismo. En el caso del Derecho Internacional, los engranajes sancionatorios tienen problemas, debido básicamente al carácter no institucionalizado de la sociedad internacional, y a los rasgos de descentralización que lo caracterizan 451 .

Rafael Casado Raigón, definiendo los elementos del Postulado que trabajaremos en este acápite, menciona que «... La violación, ya sea por acción u omisión, de cualquier obligación establecida por una norma de Derecho internacional (tenga un origen consuetudinario, convencional u otro) hace surgir una relación jurídica nueva, la de la responsabilidad internacional, relación que tradicionalmente, con independencia del contenido de la obligación y de la gravedad de la violación, se ha considerado como una relación bilateral, de Estado a Estado, que se concreta en el deber del sujeto a quien se le imputa esa violación de efectuar una reparación y en el derecho de la víctima a reclamar y obtener, según proceda, una restitución, una indemnización y/o una satisfacción...» 452 .

La Corte Interamericana de Derechos Humanos, ha recogido expresamente el Postulado, en los primeros casos contenciosos en que debió abordar la cuestión de la responsabilidad internacional de un Estado, por violaciones a la Convención Americana sobre Derechos Humanos: «... Es un principio de Derecho internacional, que la jurisprudencia ha considerado «incluso una concepción 
general de derecho», que toda violación a una obligación internacional que haya producido un daño comporta el deber de repararlo adecuadamente...» 453 .

Los tribunales internacionales, en particular la Corte Permanente de Justicia Internacional y la Corte Internacional de Justicia, han aplicado en sus decisiones, la vasta doctrina existente sobre la responsabilidad internacional.

La Corte Interamericana de Derechos Humanos, cita algunos casos de jurisprudencia internacional (Usine de Chorzów, compétence, arrêt N 8, 1927, C.P.J.I., Série A N 9 p. 21, Usine de Chorzów, fond, arrêt N 13, 1928, P.P.J.I. Série A N 17, p. 29; Interprétation des traités de paix conclus avec la Bulgarie, la Houngrie et la Roumanie, deuxième phase, avis consultatif, C.I.J., Recueil 1950, p. 228); y determina que la norma contenida en el artículo 63.1 de la Convención Americana sobre Derechos Humanos es «... una norma consuetudinaria que es, además, uno de los principios fundamentales del actual derecho de gentes...» 454 .

Establecida la responsabilidad internacional de un Estado por violaciones al Derecho Internacional de los Derechos Humanos, abordaremos ahora la cuestión de la indemnización en el sistema interamericano.

La Convención Americana sobre Derechos Humanos establece que la Corte Interamericana dispondrá «... si ello fuera procedente, que se reparen las consecuencias de la medida o situación que ha configurado la vulneración de esos derechos [se refiere a los derechos conculcados] y el pago de una justa indemnización a la parte lesionada...» 455 .

Tal como hemos sostenido «... Cuando existe una violación de los derechos humanos que se tramita en una instancia internacional, tanto los instrumentos generales (en el seno de las Naciones Unidas) como los instrumentos regionales (Convención Europea de Derechos Humanos y Convención Americana de Derechos Humanos) determinan inequívocamente el derecho de las víctimas o sus derecho habientes a una justa indemnización...» 456 .

Es decir, la indemnización por violaciones a un tratado de derechos humanos encuentra sus razones en el Derecho Internacional. En este sentido, refiriéndose al Pacto de San José de Costa Rica, la Corte Interamericana de Derechos Humanos mencionó que en su labor «... para fijar la indemnización correspondiente, debe fundarse en la Convención Americana y en los principios de derecho internacional aplicables a la materia...» 457 .

En cuanto al tipo de reparación a aplicar, las sentencias condenatorias de la Corte Interamericana han aplicado el criterio de «reparación plena» 458 .

La Corte Interamericana de Derechos Humanos se ha pronunciado en favor del concepto de la reparación integral, y así lo ha decidido y definido: «... La reparación del daño ocasionado por la infracción de una obligación internacional consiste en la plena restitución (restitutio in integrum), lo que incluye el restablecimiento de la situación anterior y la reparación de las consecuencias que la infracción produjo y el pago de una indemnización como compensación por los daños patrimoniales y extrapatrimoniales, incluyendo el daño moral...» 459 .

En diferentes ocasiones la Corte Interamericana se ha referido a los perjuicios materiales y como consecuencia de ellos, a la obligación de reparar el daño emergente y el lucro cesante. El Tribunal ha señalado que los perjuicios materiales sufridos «... comprenden tanto el daño emergente como el lucro cesante...» 460 .

Finalmente, sobre el alcance del daño moral, la jurisprudencia remarca que: «... la Corte declara que éste es resarcible según el derecho internacional y, en particular, en los casos de violación de los derechos humanos. Su liquidación debe ajustarse a los principios de la equidad...» 461 .

Cabe decir, entonces, que la Corte Interamericana de Derechos Humanos ha aplicado en su jurisprudencia contenciosa el Postulado construido a partir del Derecho Internacional, que señala que el daño producido por la violación de sus normas, engendra el derecho a una reparación adecuada. Se destaca, finalmente que dicha compensación reposa en el principio de reparación integral, y consiste en el restablecimiento del statu quo ante (en la medida de lo posible), y en la indemnización para la víctima o sus derecho habientes, por los perjuicios sufridos, incluidos daños materiales y el daño moral. 


\section{LA JURISPRUDENCIA DE LA CORTE INTERAMERICANA: POSTULADOS TOMADOS DEL DERECHO INTERNACIONAL DE LOS DERECHOS HUMANOS}

Sumario: I.- Introducción; II.- Postulados tomados del Derecho Internacional de los Derechos Humanos; II.1.- Los tratados de derechos humanos tienen una naturaleza propia, disímil de los tratados comunes en el Derecho Internacional; II.2.- Las normas de derechos humanos deben interpretarse en el sentido más favorable a las presuntas víctimas, y la actuación de los órganos de protección de los derechos humanos, debe realizarse en la misma dirección; II.3.- Los instrumentos o medios procesales destinados a garantizar los derechos humanos, deben ser efectivos; II.4.- Las declaraciones marco de derechos humanos son jurídicamente obligatorias, cuando constituyen la interpretación de los derechos humanos, contenidos en los tratados constitutivos de las Organizaciones Internacionales; II.5.- Los Estados deben aplicar y respetar, el principio de no discriminación.

\section{I.- Introducción}

Este capítulo analiza cinco Postulados, que se desprenden de la práctica jurisprudencial que ha llevado adelante la Corte Interamericana de Derechos Humanos.

Los enunciados elegidos, han sido tomados del Derecho Internacional de los Derechos Humanos, considerando a éste como una disciplina que ha nacido del Derecho Internacional Público, pero que ya ha adquirido por dimensión y prestigio, autonomía propia.

El primero de los Postulados que destacamos, se refiere a los instrumentos jurídicos de protección a los derechos humanos; normas que la Corte Interamericana debe aplicar, tanto en su competencia consultiva, como contenciosa.

En los casos resueltos contra Estados, La Corte Interamericana aplica principalmente la Convención Americana sobre Derechos Humanos, no obstante lo cual, en sus sentencias, hace mención a otros instrumentos jurídicos de protección de los derechos humanos.

En su faz consultiva, sin embargo, y tal como desarrollamos ampliamente en el Capítulo IV, y en la jurisprudencia respectiva del Capítulo VIII; la Corte Interamericana tiene una amplísima capacidad interpretativa de la Convención Americana sobre Derechos Humanos. Pero además, el Tribunal está facultado para interpretar otros tratados, aunque estos se celebren fuera del ámbito de la Organización de los Estados Americanos, y bajo ciertos requisitos 462 .

Es así que la Corte Interamericana, ha tenido oportunidad de examinar las diferencias existentes entre los tratados que se celebran en las distintas disciplinas que conforman al Derecho Internacional Público, y las convenciones cuyo objeto es la protección de los derechos humanos. El Tribunal considera, y así lo ha repetido en varias oportunidades, que en este último caso, estamos en presencia, de instrumentos jurídicos que poseen particularidades en cuanto a su naturaleza jurídica.

El segundo Postulado que veremos en este Capítulo, se refiere también a la peculiaridad de las normas de derechos humanos. En este caso, La Corte subraya ciertos aspectos en torno a la 
interpretación de dichos instrumentos, y a la propia actuación de los órganos internacionales de protección de los derechos y libertades fundamentales.

Así, el Tribunal sostiene que la regla «en favor de la víctima», es la que debe regir ambos aspectos. Puede decirse, en general, que la propia actuación de la Corte Interamericana en sus dos competencias principales, ha practicado éste principio, con la excepción del caso Cayara, el cual hemos analizado en el Capítulo anterior bajo el Postulado enunciado como «Los procedimientos del Sistema Interamericano de Derechos Humanos, deben llevarse adelante bajo el respeto al principio de seguridad jurídica».

El tercer Postulado que estudiaremos, se refiere asimismo a los tratados e instrumentos internacionales de derechos humanos, $\mathrm{y}$ a los medios procesales destinados a garantizar estos derechos.

La Corte Interamericana de Derechos Humanos, reafirma la necesidad de que las normas, sean efectivas para el fin que han sido creadas; haciendo hincapié especial en el funcionamiento de las garantías judiciales, tanto en situaciones de normalidad, como para estados de excepción.

El cuarto Postulado que analizamos, se refiere a la importancia y valor de las declaraciones de derechos humanos, algunas de las cuales, como la Declaración Universal en el marco de la Organización de las Naciones Unidas, configuran una base jurídica trascendente para el juzgamiento de violaciones a los derechos humanos.

La Corte Interamericana de Derechos Humanos, ha abordado las características de las declaraciones en general, de la Declaración Americana de Derechos y Deberes del Hombre en particular, de las diferencias existentes con los tratados o convenciones, y finalmente, del grado de obligatoriedad jurídica de aquella.

El quinto y último Postulado del presente Capítulo, toma el trabajo que la Corte Interamericana de Derechos Humanos ha desarrollado, en la aplicación de un precepto típico del Derecho Internacional de los Derechos Humanos: el principio de no discriminación.

\section{II.- Postulados tomados del Derecho Internacional de los Derechos Humanos}

Seguidamente, enunciaremos y analizaremos los cinco Postulados que hemos escogido, y a los que hemos hecho referencia en el acápite anterior, a la luz de la jurisprudencia de la Corte Interamericana de Derechos Humanos.

\section{1.- Los tratados de derechos humanos tienen una naturaleza propia, disímil de los tratados comunes en el Derecho Internacional}

Los instrumentos jurídicos que componen al Derecho Internacional de los Derechos Humanos poseen ciertas características particulares, en relación al resto de instrumentos jurídicos que forman la red legal del Derecho Internacional Público.

Ya hemos visto en el Capítulo II del presente trabajo, las incidencias que el Derecho Internacional de los Derechos Humanos ha provocado en el ordenamiento internacional convencional, o "derecho de los tratados" 463.

Retomaremos aquí algunos de los conceptos más importantes, que nos servirán para la conceptualización del Postulado que nos encontramos analizando.

Existe, en primer lugar, una diferencia básica entre un tratado de tipo tradicional y uno de derechos humanos, ya que el primero se refiere a derechos y acuerdos de Estados entre sí, y el segundo, si bien también consiste formalmente en acuerdos entre Estados, no regulan derechos recíprocos, sino que prescriben un mínimo de prerrogativas, que les corresponden a los individuos que habitan dentro del territorio de los Estados partes. Para señalarlo más claramente, la naturaleza jurídica de los instrumentos convencionales generales y los tratados de derechos humanos, difiere en cuanto a su objeto y fin.

En segundo lugar, existen distintos instrumentos de protección de derechos humanos: a las declaraciones y planes de acción que han surgido de las «megaconferencias» organizadas en la posguerra fría por las Naciones Unidas, ya nos hemos referido en el Capítulo II 464 . 
En cuanto a las declaraciones específicas de derechos humanos aprobadas en el seno de órganos permanentes de las Organizaciones Internacionales, también hemos hecho alguna referencia en el mismo acápite. Sin embargo, por ser un instrumento que la Corte Interamericana ha trabajado en su labor jurisprudencial, hacemos hincapié en la Declaración Americana de Derechos y Deberes del Hombre, en el punto II.4 del presente Capítulo.

Tal como sostiene Pastor Ridruejo «... a lo que se aspira mediante la protección internacional de los derechos del hombre es a la imposición de obligaciones a los Estados respecto de todos los individuos, nacionales o extranjeros, y a que los individuos puedan reclamar directamente contra el Estado infractor ante instancias internacionales en caso de vulneración de sus derechos...» 465 .

Efectivamente, los tratados de derechos humanos contienen obligaciones de carácter objetivo, establecidas para que los Estados protejan los derechos fundamentales de los seres humanos sometidos a su jurisdicción, sin que se creen derechos subjetivos y recíprocos entre aquellos $\mathbf{4 6 6}$.

La naturaleza distintiva de los tratados de derechos humanos (o de derecho humanitario), también ha sido distinguida por la propia jurisprudencia de la Corte Internacional de Justicia, en la opinión consultiva emitida por esta última, sobre las reservas a la Convención sobre la Prevención y el Castigo del Crimen del Genocidio 467.

La Corte Interamericana de Derechos Humanos ha entrado de lleno al análisis de la cuestión que nos ocupa, al tratar el efecto de las reservas sobre la entrada en vigencia de la Convención Americana sobre Derechos Humanos. El Tribunal se enfrentó a una típica cuestión de Derecho Internacional convencional. En su decisión, la Corte ha establecido una doctrina que ha sido repetida poco después, en la tercera Opinión Consultiva, que tuvo como objeto, un análisis del marco de aplicación de la pena de muerte en la Convención Americana sobre Derechos Humanos.

En ambas ocasiones, la Corte Interamericana sostuvo que ella «... debe enfatizar, sin embargo, que los tratados modernos sobre derechos humanos, en general, y en particular, la Convención Americana, no son tratados multilaterales del tipo tradicional, concluidos en función de un intercambio recíproco de derechos, para el beneficio mutuo de los Estados contratantes. Su objeto y fin son la protección de los derechos fundamentales de los seres humanos, independientemente de su nacionalidad, tanto frente a su propio Estado como frente a los otros Estados contratantes. Al aprobar estos tratados sobre derechos humanos, los Estados se someten a un orden legal dentro del cual ellos, por el bien común, asumen varias obligaciones, no en relación con otros Estados, sino hacia los individuos sometidos a su jurisdicción...» 468 .

Una parte de la doctrina, concordando con lo que el Tribunal ha sostenido, considera que «... los tratados tradicionales, sean multilaterales o bilaterales, persiguen un intercambio recíproco de beneficios y ventajas. De allí resulta una correlación entre los derechos y los deberes que se han convenido. Lo mismo no ocurre con las convenciones relativas a los derechos humanos, pues ellas no son un medio para equilibrar recíprocamente intereses entre Estados, sino para el establecimiento de un orden público común, cuyos destinatarios no son los Estados sino los seres humanos sujetos a su jurisdicción...» 469 .

En la segunda Opinión Consultiva, la propia Corte Interamericana de Derechos Humanos, ha sostenido que «... la Convención no puede ser vista sino como lo que ella es en realidad: un instrumento o marco jurídico multilateral que capacita a los Estados para comprometerse, unilateralmente, a no violar los derechos humanos de los individuos bajo su jurisdicción...» 470 .

En Derecho Internacional de los Derechos Humanos, no puede hacerse jugar el principio de reciprocidad, por el cual el incumplimiento de un tratado por una de las partes genera el fin del compromiso para la otra parte471 .

En la propia decisión sobre el momento de la entrada en vigencia de la Convención para un Estado que ha formulado reservas a la misma, la Corte Interamericana se aparta del Derecho Internacional tradicional, regido en la materia por la Convención de Viena sobre Derecho de los Tratados, determinando que el régimen de esta sólo es parcialmente aplicable. La Corte tuvo en cuenta la importancia de que un Estado sea vinculado jurídicamente al Pacto de San José de Costa Rica lo antes posible, y adoptó para ello un criterio propio, desvinculándose de las disposiciones de la Convención de Viena 472 (ver página siguiente). 
Cabe concluir, entonces, que las convenciones de derechos humanos son diferentes a los tratados tradicionales del Derecho Internacional, en virtud del fin, el contenido, y por último, de las obligaciones asumidas por los Estados partes frente a la comunidad internacional, respecto a los individuos sometidos a su jurisdicción.

\section{2.- Las normas de derechos humanos deben interpretarse en el sentido más favorable a las presuntas víctimas, y la actuación de los órganos de protección de los derechos humanos, debe realizarse en la misma dirección}

La mencionada regla es un desprendimiento del principio conocido como «pro homine», propio del Derecho Internacional de los Derechos Humanos.

Hitters destaca que según la Convención de Viena, los tratados deben interpretarse de buena fe, y teniendo en cuenta su objeto y fin; y que «... si a esto le agregamos que cuando tal tipo de instrumentos internacionales se refieren a derechos humanos, su télesis apunta a la protección del hombre, fácil es colegir que desde tal cuadrante es factible ver lo que ha dado en llamarse el método de interpretación humanitario, que apunta en definitiva a extraer de ellos justamente los principios que favorezcan al hombre como destinatario último de los mismos...» 473 .

Dentro de la Convención Americana sobre Derechos Humanos, el artículo 29 registra una aplicación del principio «pro homine». La citada norma dice que ninguna disposición del Pacto de San José puede interpretarse en el sentido de «... permitir a alguno de los Estados partes, grupo o persona, suprimir el goce y ejercicio de los derechos y libertades reconocidos en la Convención, o limitarlos en mayor medida que la prevista en ella... limitar el goce y ejercicio de cualquier derecho o libertad que pueda estar reconocido de acuerdo con las leyes de cualquiera de los Estados Partes o de acuerdo con otra convención en que sea parte uno de dichos Estados... excluir otros derechos y garantías que son inherentes al ser humano o que se derivan de la forma democrática representativa de gobierno... excluir o limitar el efecto que puedan producir la Declaración Americana de Derechos y Deberes del Hombre y otros actos internacionales de la misma naturaleza...» 474 .

La jurisprudencia de la Corte Interamericana ha sido uniforme en este sentido; el fin de sus decisiones fue, en general, la protección de la persona y sus derechos elementales.

Pero la afirmación sin duda del principio, se destaca en el siguiente párrafo de la Opinión Consultiva N 5 emitida por el Tribunal: «... si a una misma situación son aplicables la Convención Americana y otro tratado internacional, debe prevalecer la norma más favorable a la persona humana...» 475 .

En igual sentido, dentro de las partes resolutivas de sus opiniones consultivas, la Corte Interamericana de Derechos Humanos ha favorecido, en general, el principio «pro homine».

Así, por ejemplo, ha resuelto que los derechos establecidos en la Convención Americana de Derechos Humanos deben considerarse, por regla general, operativos: «... el sistema mismo de la Convención, está dirigido a reconocer derechos y libertades a las personas, y no a facultar a los Estados para hacerlos...» 476 .

La Corte toma como base de tal afirmación el artículo 1.1 de la Convención Americana sobre Derechos Humanos, el cual establece en la parte pertinente: «... Los Estados partes en esta Convención se comprometen a respetar los derechos y libertades reconocidos en ella y a garantizar su libre y pleno ejercicio a toda persona que esté sujeta a su jurisdicción...» 477 .

Asimismo, la Corte sostiene que cuando dentro de un Estado una norma establecida por la Convención no es operativa, para cumplir la obligación del artículo 1.1, cualquier norma jurídica interna es válida.

Sobre uno de los derechos contenidos en el seno de la Convención, el derecho de rectifícación o respuesta, el tribunal sostuvo que : «... Si se leen conjuntamente los artículos 14.1, 1 y 2 de la Convención, todo Estado Parte que no haya ya garantizado el libre y pleno ejercicio del derecho de rectificación o respuesta, está en la obligación de lograr ese resultado, sea por medio de legislación o cualquiera otras medidas que fuesen necesarias, según su ordenamiento jurídico interno para cumplir ese fin...» 478 . 
Sin embargo, el tribunal había establecido anteriormente que cuando se trate de restringir los derechos o libertades establecidos en la Convención Americana (aquellos que son pasibles de ser restringidos según prescribe el mismo Pacto de San José de Costa Rica en su capítulo IV), el mecanismo a utilizar es la sanción de «leyes» en sentido restringido o formal.

En efecto, como hemos expresado en el Capítulo anterior al analizar el principio de legalidad en la jurisprudencia de la Corte Interamericana, para restringir el goce de los derechos humanos, un Estado debe acudir al principio de legalidad, y tiene como límite jurídico a la propia Convención Americana.

Por ende, la decisión se sostiene en el principio «pro homine»: «... la palabra leyes en el artículo 30 de la Convención significa norma jurídica de carácter general, ceñida al bien común, emanada de los órganos legislativos constitucionalmente previstos y democráticamente elegidos, y elaborada según el procedimiento establecido por las constituciones de los Estados Partes para la formación de las leyes...» 479 .

De la lectura de las opiniones consultivas sexta y séptima, se deriva que la Corte Interamericana considera que los derechos que están en el Pacto de San José de Costa Rica son exigibles sin mayores requisitos para los Estados Partes; asimismo, que si hay dificultades legislativas para el disfrute de los mismos, el Estado está en la obligación de adoptar las medidas de derecho interno que sean necesarias; también, que dichas providencias pueden ser de cualquier tipo; y, finalmente, que cuando se trate de suspender o restringir derechos, sólo es posible hacerlo por medio de una ley formal.

La combinación de las opiniones de la Corte en esta decisión, marca una dirección hacia una mejor tutela de los derechos y libertades, que se encuentran contenidos en la Convención Americana sobre Derechos Humanos.

La Corte Interamericana de Derechos Humanos también ha interpretado en sentido amplio, las garantías imposibles de suspensión en circunstancias excepcionales o estados de excepción, vedando el accionar de los gobiernos en desmedro de los derechos humanos fundamentales, cuando existen tensiones o situaciones de conflicto dentro de las fronteras de un Estado.

El régimen de suspensión de garantías se encuentra regulado en el Capítulo IV de la Convención Americana. El inciso segundo del artículo 27, enuncia cuales derechos no son pasibles de ser suspendidos en ningún caso, agregando al final de la disposición que tampoco pueden suspenderse «... las garantías judiciales indispensables para la protección de tales derechos...»480 .

La Corte Interamericana ha dispuesto en la primera ocasión que abordó el problema, que «... los procedimientos jurídicos consagrados en los artículos 25.1 y 7.6 de la Convención Americana sobre Derechos Humanos no pueden ser suspendidos conforme al artículo 27.2 de la misma, porque constituyen garantías judiciales indispensables para proteger derechos y libertades que tampoco pueden suspenderse según la misma disposición 481.

Nuevamente la Corte volvió sobre la cuestión en la novena Opinión Consultiva. El tribunal dirigió su razonamiento en favor de las personas: «... Debe reconocerse que no es posible ni sería aconsejable que la Corte, en la presente opinión consultiva, trate de dar una enumeración exhaustiva de todas las posibles «garantías judiciales indispensables» que no pueden ser suspendidas de conformidad con el artículo 27.2, que dependerá en cada caso de un análisis del ordenamiento jurídico y la práctica de cada Estado Parte, de cuales son los derechos involucrados y de los hechos concretos que motivan la indagación...»; y que «... deben considerarse como garantías judiciales indispensables que no pueden suspenderse, aquellos procedimientos judiciales, inherentes a la forma democrática representativa de gobierno (art. 29.c), previstos en el derecho interno de los Estados Partes como idóneos para garantizar la plenitud del ejercicio de los derechos a que se refiere el artículo 27.2 de la Convención y cuya supresión o limitación comporte la indefensión de tales derechos $\mathbf{4 8 2}$.

La segunda parte del Postulado que sostenemos, se refiere a la actuación de los órganos de protección de los derechos humanos. Haremos hincapié al desarrollo del principio «pro homine», en la acción diseñada en la propia jurisprudencia de la Corte Interamericana de Derechos Humanos. 
El Tribunal, como hemos señalado anteriormente, ha resuelto siempre en favor de sus más amplias posibilidades de actuar, en particular en lo que se refiere a su faz consultiva $\mathbf{4 8 3}$.

En varias decisiones, la Corte ha sostenido que uno de los límites a esta actuación y competencia, se da por la posibilidad de que esta amplitud vaya en desmedro de los derechos humanos de alguna persona $\mathbf{4 8 4}$.

No haremos una explicación de ambas cuestiones, debido a que el desarrollo de la función consultiva de la Corte ha sido ya abordado en el Capítulo IV del presente, y a él nos remitimos; y el Postulado principal derivado de la Competencia Consultiva de la Corte (su grado de amplitud) se encuentra en el Capítulo VIII, donde se analizan los Postulados emergentes de la jurisprudencia de la Corte Interamericana, que consideramos como de pura creación pretoriana del Tribunal.

La Corte Interamericana de Derechos Humanos se ha pronunciado intencionalmente, por la vinculación de los Estados Partes a las obligaciones estipuladas en la Convención Americana de Derechos Humanos, en la oportunidad más temprana que ofrece el Derecho Internacional, y a pesar que un Estado haya formulado reservas a la misma. La obligatoriedad jurídica se le presenta al momento de ratificar o adherir al tratado, tal como hemos señalado en el acápite anterior 485 .

El principio «pro homine» ha sido destacado por la Corte Interamericana de Derechos Humanos cuando le ha tocado tratar las excepciones al agotamiento de los recursos internos, adecuando los requisitos de esta regla del Derecho Internacional general, a la protección internacional de los derechos humanos (ver Capítulo VI) 486 .

Sobre las restricciones a la pena de muerte según la Convención Americana sobre Derechos Humanos, la Corte Interamericana de Derechos Humanos, haciendo jugar en este último caso, una interpretación restrictiva de la capacidad de los Estados Partes del Pacto de San José de Costa Rica en torno a la sanción y aplicación de la pena de muerte, ha evaluado las disposiciones de la Convención Americana sobre Derechos Humanos conforme al sentido y fin del tratado, es decir, respetando el principio «pro homine».

Conforme a lo señalado, la Corte ha dicho que «... la Convención prohibe absolutamente la extensión de la pena de muerte y que, en consecuencia, no puede un gobierno de un Estado Parte aplicar la pena de muerte a delitos para los cuales no estaba contemplada anteriormente en su legislación interna...» 487 .

En su faz contenciosa, también la Corte Interamericana de Derechos Humanos hizo valer el Postulado que analizamos, teniendo en cuenta las dificultades para producir la prueba de situaciones tales como la desaparición forzada «... a diferencia del derecho penal interno, en los procesos sobre violaciones a los derechos humanos la defensa del Estado no puede descansar sobre la imposibilidad del demandante de alegar pruebas que, en muchos casos, no pueden obtenerse sin la cooperación del Estado...» 488 .

Para cerrar este acápite, puede decirse que, en general, una gran parte de la jurisprudencia de la Corte Interamericana de Derechos Humanos, ha ido en el sentido de la protección de los derechos de las víctimas.

La propia Corte ha sido consciente, sin embargo, que el principio «pro homine» no puede traducirse como «el peticionario en un caso de derechos humanos siempre tiene razón».

Es por lo anterior que, en aras de otro importante principio - el de la seguridad jurídica -, la Corte Interamericana ha creído conveniente aceptar las excepciones preliminares presentadas por un Estado, y por ende terminar el procedimiento sin pronunciarse sobre el fondo, en uno de los casos más terribles que han llegado a su jurisdicción contenciosa, la conocida como «masacre de Cayara» producida en la República del Perú, y que ha quedado lamentablemente impune 489 .

\section{3.- Los instrumentos o medios procesales destinados a garantizar los derechos humanos, deben ser efectivos \\ E1 Derecho Internacional de los Derechos Humanos, es un ordenamiento jurídico dirigido en dos vías; la primera de ellas hacia la protección efectiva de las víctimas de violaciones, y la segunda para evitar violaciones, (sentido preventivo). Este corpus jurídico, ha desarrollado una máxima que}


estipula, que tanto los instrumentos jurídicos que consagran derechos, como especialmente los medios procesales para salvaguardarlos, deben ser efectivos.

La Corte Interamericana de Derechos Humanos se ha hecho eco, de tal axioma, y de su jurisprudencia extraemos el Postulado que analizamos. El Tribunal, ha mencionado que «... El artículo 25.1 [de la Convención Americana] incorpora el principio, reconocido en el Derecho Internacional de los Derechos Humanos, de la efectividad de los instrumentos o medios procesales destinados a garantizar tales derechos...» 490 .

Asimismo, en la resolución de las excepciones preliminares de los primeros casos contenciosos resueltos, la Corte sostuvo «...Los Estados Partes se obligan a suministrar recursos judiciales efectivos a las víctimas de violación de los derechos humanos (art. 25), recursos que deben ser substanciados de conformidad con las reglas del debido proceso legal (art. 8.1), todo ello dentro de la obligación general a cargo de los mismos Estados, de garantizar el libre y pleno ejercicio de los derechos reconocidos por la Convención a toda persona que se encuentre bajo su jurisdicción...» 491 .

La Corte ha ido más allá, responsabilizando al Estado cuando viola este principio por omisión «... la inexistencia de un recurso efectivo contra las violaciones a los derechos reconocidos por la Convención constituye una transgresión de la misma por el Estado Parte en el cual semejante situación tenga lugar...» 492 .

Asimismo, la Corte enfatizó que «... es violatoria de la Convención toda disposición adoptada por virtud del estado de emergencia, que redunde en la suspensión de esas garantías...» 493 .

Existe de acuerdo a lo examinado, una opinión sostenida del Tribunal, que subraya la importancia de la efectividad de los instrumentos y medios de protección, para una eficaz tutela de los derechos humanos.

\section{4.- Las declaraciones marco de derechos humanos son jurídicamente obligatorias, cuando constituyen la interpretación de los derechos humanos, contenidos en los tratados constitutivos de las organizaciones internacionales}

En el último acápite del Capítulo II, hacíamos mención a la diferencia entre el Derecho Internacional clásico y el Derecho Internacional Contemporáneo en materia de derecho de los tratados; quisiéramos retomar algunos de esos conceptos para adosar la jurisprudencia de la Corte Interamericana de Derechos Humanos sobre la obligatoriedad de la Declaración Americana de Derechos y Deberes del Hombre.

Efectivamente, mencionábamos en dicho acápite que según Daniel O’ Donnel «... Una de las máximas del Derecho Internacional clásico - que se aplica al derecho internacional de los derechos humanos con importantes reservas - es la distinción hermética entre los tratados como instrumentos obligatorios y las declaraciones como no obligatorias...» 494.

Estas «importantes reservas» que menciona el autor, tienen que ver en su opinión, con la obligatoriedad de la Declaración Universal de los Derechos Humanos para los Estados miembros de la Organización de las Naciones Unidas 495.

También podemos señalar la existencia de la misma máxima en la Organización de los Estados Americanos, debido a la aplicación de la Declaración Americana de Derechos y Deberes del Hombre, que efectúa de la Comisión Interamericana de Derechos Humanos para todos los Estados miembros de la OEA, siendo indiferente que éstos hayan o no ratificado el Pacto de San José de Costa Rica, y mucho menos que hayan o no aceptado la competencia contenciosa de la Corte Interamericana 496 .

Es decir, la Declaración Americana de Derechos y Deberes del Hombre, ha devenido de cumplimiento obligatorio para todos los Estados miembros de la Organización de los Estados Americanos.

La Comisión Interamericana de Derechos Humanos, ha tenido oportunidad de evaluar la cuestión de la obligatoriedad de la Declaración Americana de los Derechos y Deberes del Hombre. 
Dicho órgano ha sostenido el criterio de obligatoriedad, al mencionar que cualquier Estado parte de la Organización de los Estados Americanos, es responsable internacionalmente por el incumplimiento de las disposiciones de la Declaración Americana 497.

Son varios los Estados que han sido declarados responsables de haber violado la Declaración Americana de Derechos y Deberes del Hombre, incluso algunos que no habían ratificado ningún instrumento de derechos humanos del sistema 498 .

De la jurisprudencia de la Corte Interamericana de Derechos Humanos se infiere que, tal como veremos, la obligatoriedad de la Declaración Americana de Derechos y Deberes del Hombre no se deriva por la autonomía de dicho instrumento, sino del hecho de constituir, el desarrollo de los derechos humanos contenidos en la Carta de la Organización de los Estados Americanos.

La Carta de la Organización de los Estados Americanos habla en varios lugares de los derechos humanos, pero ni los define ni dice cuales son, con lo cual se estima que se trata de los derechos consagrados en la Declaración, y por evolución, en los posteriores instrumentos que se han adoptado en el sistema interamericano.

La Corte Interamericana de Derechos Humanos, en este sentido, sostuvo en una Opinión Consultiva específicamente sobre la cuestión que aquí tratamos, que: «... La Corte considera necesario precisar que no es a la luz de lo que en 1948 se estimó que era el valor y la significación de la Declaración Americana como la cuestión del status jurídico debe ser analizada, sino que es preciso determinarlo en el momento actual, ante lo que hoy es el sistema interamericano, habida consideración de la evolución experimentada desde la adopción de la Declaración...» 499.

Cançado Trindade hace notar que «... la Declaración Americana formó la base normativa de la materia en el período que antecede la adopción de la Convención Americana sobre Derechos Humanos en 1969, y sigue siendo, la base normativa vis à vis para los Estados no Partes en la Convención Americana...» 500 .

También, la Corte Interamericana de Derechos Humanos, recurrió a la interpretación que de la Declaración Americana de Derechos y Deberes del Hombre, han hecho otros órganos de la Organización de los Estados Americanos.

En este sentido, sostuvo que «... La Asamblea General de la Organización ha reconocido además, reiteradamente, que la Declaración Americana es una fuente de obligaciones internacionales para los Estados Miembros de la OEA...» 501 .

En el mismo sentido, Cecilia Medina hace notar que «... Un problema fundamental para poder implementar y exigir el respeto de los derechos humanos por parte de los Estados miembros de la OEA era la falta de definición en la Carta respecto a cuales eran estos derechos. Para resolverlo, cuando el sistema empezó a desarrollarse, la Declaración se incorporó al Estatuto de la Comisión y fue constantemente aplicada como la norma que regía la conducta de los Estados miembros de la OEA en materia de Derechos Humanos. La doctrina ha sostenido que siendo la Declaración una resolución de un organismo internacional, adoptada en forma unánime por los mismos Estados que están ligados a la Carta, puede ser considerada como una complementación de las normas establecidas en los artículos 5 (j) y 13 y es, por lo tanto, obligatoria para los Estados miembros de la OEA...» 502 .

Finalmente, la Corte Interamericana de Derechos Humanos también expresó que «... Puede considerarse entonces que, a manera de interpretación autorizada, los Estados Miembros han entendido que la Declaración contiene y define aquellos derechos humanos esenciales a los que la Carta se refiere, de manera que no se puede interpretar y aplicar la Carta de la Organización en materia de derechos humanos, sin integrar las normas pertinentes de ella con las correspondientes disposiciones de la Declaración, como resultado de la práctica seguida por los órganos de la OEA...» 503 .

Como podrá observarse, la cuestión bajo nuestro examen sólo ha sido tratada en una Opinión Consultiva de la Corte Interamericana de Derechos Humanos y, por ende, la jurisprudencia clasificada ha sido de esa decisión.

Sin embargo, creemos que es válida para sostener el Postulado al que hacemos mención y enunciamos aquí, por varias razones. 
En primer lugar, porque la respuesta otorgada por el Tribunal se refiere específicamente a la Declaración Americana de Derechos y Deberes del Hombre, y a la facultad interpretativa de la Corte Interamericana de Derechos Humanos en el marco de su función consultiva.

En segundo término, porque la validez jurídica de la Declaración Americana de Derechos y Deberes del Hombre es fundamental para una eficaz protección de los derechos humanos en el continente americano, si consideramos que aún diez miembros de la Organización de los Estados Americanos, no han ratificado el Pacto de San José de Costa Rica.

En tercer lugar porque la Declaración ha sido incorporada al Estatuto de la Comisión Interamericana, y ésta es un órgano principal de la Organización de los Estados Americanos, cuya Carta es, naturalmente, de cumplimiento obligatorio para los Estados Miembros.

Por último, nótese que hacemos referencia a un Postulado general (sobre las declaraciones marco de derechos humanos) cuando la jurisprudencia señalada se refiere tan sólo a la Declaración Americana; dicha acción es deliberada de nuestra parte.

Efectivamente, remitimos a la validez de la Declaración Universal de los Derechos Humanos, consagrada en la Proclamación de Teherán de 1968, pero también de la práctica de la Comisión de Derechos Humanos de las Naciones Unidas en la aplicación de los procedimientos extraconvencionales que hemos analizado en el Capítulo III, derivada de razonamientos similares a los utilizados por la Corte Interamericana, aunque en este caso los órganos son el Consejo Económico y Social de las Naciones Unidas y la Comisión de Derechos Humanos; y las normas son la Carta de las Naciones Unidas, la Declaración Universal de los Derechos Humanos y las resoluciones del Consejo Económico y Social que han sancionado los procedimientos extraconvencionales 504 .

Pero aún existen discusiones respecto a la obligatoriedad jurídica de la Declaración Universal, que no ha encontrado un apoyo institucional tan claro como su equivalente americana. En todo caso, las opiniones de la Corte que tienden a afianzar la validez jurídica de la Declaración Americana, en tanto choca con problemas planteados por el Derecho Internacional Público tradicional, podrá ayudar al sostenimiento de la obligatoriedad jurídica de la Declaración Universal de Derechos Humanos.

Bien entendido aquí, que sólo nos referimos a las declaraciones de derechos humanos, que explican y desarrollan los derechos a que se refieren los instrumentos constitutivos de Organizaciones Internacionales, y se aplican en la práctica seguida por algún órgano de los mismos.

\section{5.- Los Estados deben aplicar y respetar, el principio de no discriminación}

Discriminar significa en su significado corriente separar, distinguir una cosa de otra, lo cual, naturalmente, no significa necesariamente una violación a los derechos humanos.

Sin embargo, en materia jurídica internacional, la discriminación configura un ataque directo a los derechos humanos. De allí que el Derecho Internacional de los Derechos Humanos, consagre como uno de sus principios básicos la "no discriminación".

El Derecho Internacional de los Derechos Humanos no niega toda posibilidad de trato discriminatorio, siempre que dicho tratamiento sea en favor de una determinada categoría de personas, en virtud generalmente de una necesidad de protección especial; se trata de la llamada «discriminación positiva».

Un ejemplo de lo señalado lo encontramos en la Convención de los Derechos del Niño, cuando en su regulación prohibe que los niños y adolescentes, hasta determinada edad, participen en conflictos armados, lo cual le da a dichas personas un trato discriminatorio respecto aquellos que son mayores de la edad establecida por la Convención; pero se trata, en este caso, de una discriminación en favor de la tutela de los derechos de los niños y adolescentes, por ende, mal puede ser castigada por el Derecho Internacional de los Derechos Humanos 505.

Hemos hecho un desarrollo de la protección específica de los derechos humanos a propósito de un trabajo sobre derechos de la mujer; en él señalamos que «... La necesidad de una protección específica frente a situaciones particulares en materia concerniente a la mujer, está explicada perfectamente: aunque, naturalmente, las normas genéricas de derechos humanos abordan la 
protección de la mujer, se hace necesario el reconocimiento palmario de los derechos de la mujer como derechos humanos en instrumentos puntuales...» 506 .

Pero el propio concepto de derechos humanos se derrumba si se acepta una discriminación en el sentido negativo, ya que éstos constituyen un vallado que ningún Estado puede atravesar, por motivo alguno. De allí que se considere que los derechos humanos son válidos para todas las personas, cualquiera sea su raza, sexo, idioma, religión, opinión política, posición social, elección sexual, etc.

Sin duda, la discriminación es un ataque a uno de los derechos humanos esenciales de la persona: el derecho a la identidad en sentido amplio $\mathbf{5 0 7}$.

Como señala Héctor Gros Espiell, la no discriminación es un elemento constitutivo del concepto de los derechos humanos, ya que todo hombre tiene todos los derechos y libertades que corresponden al ser humano sin que sea admitida distinción o discriminación alguna por razón de raza, sexo, idioma, religión, opinión política o de cualquier otra índole, origen nacional o social, posición económica, nacimiento, o cualquier otra condición 508 .

De igual forma, los principales instrumentos de derechos humanos, tanto a nivel de la Organización de las Naciones Unidas como en las Organizaciones Internacionales regionales, consagran el principio de no discriminación como una base elemental para la protección de los derechos y libertades fundamentales $\mathbf{5 0 9}$.

En el sistema interamericano, los instrumentos marco de derechos humanos también se refieren expresamente al principio de no discriminación $\mathbf{5 1 0}$.

Fundamentalmente, la Convención Americana sobre Derechos Humanos establece en el primer párrafo de su artículo 1 «... Los Estados partes en esta Convención se comprometen a respetar los derechos y libertades reconocidos en ella y a garantizar su libre y pleno ejercicio a toda persona que esté sujeta a su jurisdicción, sin discriminación alguna por motivos de raza, color, sexo, idioma, religión, opiniones políticas o de cualquier otra índole, origen nacional o social, posición económica, nacimiento o cualquier otra condición social...» $\mathbf{5 1 1}$.

El sistema interamericano de derechos humanos, también cuenta con instrumentos de protección categorial específica, como la Convención de Belem do Pará para la Erradicación y Sanción de la violencia contra la Mujer512 .

La Corte Interamericana de Derechos Humanos ha recogido el principio de no discriminación, en varios párrafos de una de sus decisiones en materia consultiva.

Así, en la cuestión atinente a la propuesta de modificación a la Constitución política de Costa Rica, el Tribunal sostuvo que «... La noción de igualdad se desprende directamente de la unidad de naturaleza del género humano y es inseparable de la dignidad esencial de la persona, frente a la cual es incompatible toda situación que, por considerar superior a un determinado grupo, conduzca a tratarlo con privilegio; o que, a la inversa, por considerarlo inferior, lo trate con hostilidad o de cualquier forma lo discrimine del goce de derechos que sí se reconocen a quiénes no se consideran incursos en tal situación de inferioridad. No es admisible crear diferencias de tratamiento entre seres humanos que no se correspondan con su única e idéntica naturaleza...» $\mathbf{5 1 3}$.

El concepto de discriminación positiva, al que hemos hecho referencia en los primeros párrafos del presente acápite, también ha sido recogido por la Corte Interamericana en su jurisprudencia tanto contenciosa como consultiva.

Así, en el caso Aloeboetoe y otros, la Corte Interamericana de Derechos Humanos lo ha aplicado, y señaló que «... las pruebas producidas permiten deducir que las leyes de Suriname sobre esa materia no tienen eficacia respecto de aquella tribu; sus integrantes las desconocen y se rigen por sus propias reglas y el Estado, por su parte, no mantiene la estructura necesaria para el registro de matrimonios, nacimientos y defunciones, requisito indispensable para la aplicación de la ley surinamesa...» «... esta [ la Corte se refiere a la costumbre saramaca ] será aplicada para interpretar aquellos términos en la medida en que no sea contraria a la Convención Americana...» 514 .

En sentido concordante con lo anterior, el Tribunal expresó que «... Existen, en efecto, ciertas desigualdades de hecho que legítimamente pueden traducirse en desigualdades de tratamiento 
jurídico, sin que tales situaciones contraríen la justicia. Por el contrario, pueden ser un vehículo para realizarla o para proteger a quiénes aparezcan como jurídicamente débiles...» $\mathbf{5 1 5}$.

Respecto a los casos contenciosos resueltos, la Corte no ha hecho mención expresa al principio de no discriminación, aunque sí en la interpretación de normas del Pacto de San José de Costa Rica, el Tribunal nunca ha dejado ver que dichas reglas se apliquen a unos individuos sí y a otros no.

La regulación jurídico internacional del principio de no discriminación, se encuentra en tratados de derechos humanos dentro de la Organización de las Naciones Unidas, como así también de las organizaciones regionales, particularmente la Organización de los Estados Americanos.

Cabe concluir, entonces, que el mantenimiento y respeto al principio de no discriminación es uno de los axiomas medulares del Derecho Internacional de los Derechos Humanos, y ha sido tomado por la Corte para la elaboración de su tarea. 


\title{
LA JURISPRUDENCIA DE LA CORTE INTERAMERICANA: LOS POSTULADOS DE CREACIÓN PRETORIANA
}

\begin{abstract}
Sumario: I.- Introducción; II.- Postulados emergentes de la Corte Interamericana, de pura creación pretoriana; II.1.- El ámbito de la función consultiva de la Corte Interamericana es el más amplio posible, dentro de los límites establecidos por la Convención Americana sobre Derechos Humanos; II.2.- Cuando se dan ciertos requisitos, la Comisión debería considerar especialmente, la posibilidad de llevar un caso contencioso ante la Corte Interamericana de Derechos Humanos; II.3.- La desaparición forzada de personas, es una forma compleja de violación de varios derechos fundamentales; II.4.- Los hijos menores de víctimas de violaciones al derecho a la vida, deben tener asegurado especialmente su derecho a la educación.
\end{abstract}

\section{I.- Introducción}

Este Capítulo recoge cuatro enunciados que se desprenden de la práctica jurisprudencial de la Corte Interamericana de Derechos Humanos, con la característica de que han sido engendrados por el propio trabajo del Tribunal a través de sus sentencias y resoluciones.

Los "Postulados de creación pretoriana" han sido creados por la Corte Interamericana, para responder a necesidades concretas de la protección de los derechos humanos en el continente.

El primero de ellos, se refiere a la propia extensión del trabajo de la Corte Interamericana de Derechos Humanos en materia consultiva, lo cual ha sido abordado por el Tribunal, tanto en las opiniones demandadas sobre este tema específicamente, como en opiniones consultivas sobre otros temas de derechos humanos. Particularmente, la Corte desarrolla una interesante doctrina, cuando ha interpretado algunos preceptos de la Convención Americana sobre Derechos Humanos.

El segundo Postulado escogido, plantea una cuestión crucial y de enorme relevancia para la puesta en practica de la protección internacional de los derechos y libertades fundamentales en el sistema interamericano de derechos humanos: se refiere a si, a pesar de que remitir un caso a la Corte Interamericana constituye una facultad de la Comisión Interamericana de Derechos Humanos y de los Estados, existirían ciertos supuestos, traducidos en las características de un asunto que tramita ante la Comisión, que impulsen a esta a considerar especialmente elevar el caso ante la Corte para que ésta lo trate en su jurisdicción contenciosa.

El tercer Postulado derivó del arribo a la Corte Interamericana de Derechos Humanos, de los primeros casos contenciosos, cuyo objeto era el tratamiento de una modalidad represiva que ha sido sistemática en toda América Latina durante la década de 1970 y buena parte de la década de 1980: la desaparición forzada de personas.

El cotejo de los hechos que implica la desaparición forzada, y la adecuación normativa de los mismos a los preceptos de la Convención Americana sobre Derechos Humanos, ha llevado a la Corte Interamericana a elaborar una sólida jurisprudencia sobre los conceptos jurídicos implicados en un caso de éstas características, y respecto a las violaciones puntuales a la Convención Americana que dicha práctica conlleva.

El último de los Postulados creados por la jurisprudencia de la Corte Interamericana de Derechos Humanos, que hemos escogido para su análisis, deriva a la violación del derecho elemental, a partir del cual pueden gozarse los demás: el derecho a la vida. En las modalidades reparatorias, el hecho 
de ser necesariamente los derecho habientes de la víctima quiénes reciben la indemnización, ha llevado a la Corte a establecer un monto destinado al ejercicio del derecho a la educación, para los hijos menores de quien ha sido privado ilegítimamente de la vida, en un hecho imputable directa o indirectamente al Estado.

\section{II.- Postulados emergentes de la Corte Interamericana, de pura creación pretoriana}

Destacamos, a continuación, los cuatro Postulados a que hemos hecho referencia en el acápite anterior, en la óptica de la jurisprudencia de la Corte Interamericana de Derechos Humanos.

\section{1.- El ámbito de la función consultiva de la Corte Interamericana es el más amplio posible, dentro de los límites establecidos por la Convención Americana sobre Derechos Humanos}

La función consultiva de los tribunales internacionales no es una creación de la jurisprudencia de la Corte Interamericana de Derechos Humanos. En efecto, ya hemos visto que, tanto la Corte Internacional de Justicia, como el Tribunal Europeo de Derechos Humanos, poseen competencias consultivas, incluso desde antes que se ponga en funcionamiento la propia Corte regional que tiene su sede en San José de Costa Rica.

Lo que sí afirmamos en el presente punto, es que el alcance al que ha arribado la función consultiva de la Corte Interamericana de Derechos Humanos, se debe no sólo a la base legal que le otorga la Convención Americana, sino también a la interpretación y creación sobre esa base, que han sido realizadas en la tarea del Tribunal.

Tal como mencionamos en el Capítulo IV, la función consultiva de la Corte se ejerce respecto de la interpretación de la Convención Americana sobre Derechos Humanos y de otros instrumentos. Asimismo, la Corte es competente para dictaminar respecto a la compatibilidad entre las leyes internas de los Estados y aquellas normas internacionales.

Ahora bien, la propia Corte en el ejercicio de su actuación, ha despejado las dudas sobre el alcance de la función consultiva que expresan los términos de la Convención Americana.

La Corte Interamericana de Derechos Humanos, a través de sus sentencias, ha ido resolviendo siempre en favor de su más amplias competencias, por medio de una interpretación netamente extensiva. Se destacan particularmente, las decisiones tomadas en torno a las materias que pueden ser objeto de una consulta.

El artículo 64 de la Convención habla de «otros tratados». El gobierno peruano ha llevado un pedido a la Corte Interamericana de Derechos Humanos donde le demandaba cuál es el sentido de la frase «otros tratados». Ya hemos mencionado que la respuesta de la Corte ha sido contundente: cualquier tratado internacional, sea o no sea su objeto principal la protección de los derechos humanos, que sea aplicable en algún Estado Americano.

Es decir que, por ejemplo, la Corte puede interpretar en su función consultiva un tratado celebrado en un ámbito externo al sistema interamericano, y cuyo objeto verse sobre una temática diferente.

Siendo coherente con la decisión anterior, el Tribunal ha interpretado, por ejemplo, algunas cláusulas de la Convención de Viena sobre Derecho de los Tratados de 1969, celebrada en el ámbito de la Organización de las Naciones Unidas 516.

La Corte ha expresado, con contundencia, que su función consultiva se ejerce «... en general, sobre toda disposición, concerniente a la protección de los derechos humanos, de cualquier tratado internacional aplicable en los Estados americanos, con independencia de que sea bilateral o multilateral, de cuál sea su objeto principal o de que sean o puedan ser partes del mismo Estados ajenos al sistema interamericano...» $\mathbf{5 1 7}$.

Como observamos, basta que un tratado haya sido ratificado por un Estado miembro de la Organización de los Estados Americanos, para que la Corte Interamericana pueda interpretarlo dentro del objeto y fin de la Convención Americana.

El señalar tamaña amplitud interpretativa de la Corte Interamericana nos lleva a una pregunta ¿Esto significaría que aquellos instrumentos que no sean tratados quedarían fuera de la esfera de interpretación del tribunal? 
Ha sido otra Opinión Consultiva (que responde a un pedido elaborado por el Estado de Colombia), la que dio al Tribunal la posibilidad de interpretar el alcance de su propia función consultiva, en relación a la Declaración Americana de Derechos y Deberes del Hombre.

En su pedido, el Estado sudamericano preguntaba si la Corte puede interpretar la Declaración Americana de Derechos y Deberes del Hombre, la cual naturalmente no configura un tratado en el sentido técnico de la Convención de Viena sobre el Derecho de los Tratados.

Luego de recabar las opiniones de los Estados Miembros (donde no había en absoluto una uniformidad de criterios), la Corte ha resuelto que «... El artículo 64.1 de la Convención Americana autoriza a la Corte para, a solicitud de un Estado Miembro de la OEA o, en lo que les compete, de uno de los órganos de la misma, rendir opiniones consultivas sobre la interpretación de la Declaración Americana de los Derechos y Deberes del Hombre, en el marco y dentro de los límites de su competencia en relación con la Carta y la Convención u otros tratados concernientes a la protección de los derechos humanos en los Estados Americanos» 518 .

O sea, la Corte puede interpretar la Declaración Americana, aunque debe hacerlo siempre en relación a los otros instrumentos mencionados en la parte dispositiva de la opinión emitida. Como vemos, la Corte no se ha referido a otros instrumentos internacionales que no sean tratados, sino sólo a uno de ellos: la Declaración Americana de Derechos y Deberes del Hombre.

Pasamos ahora a la tercera cuestión planteada a lo largo de la jurisprudencia de la Corte Interamericana, en relación al alcance de su función consultiva.

Un análisis exegético del párrafo 2 del artículo 64 de la Convención Americana, nos llevaría al convencimiento de que un Estado Miembro de la OEA, puede realizar consultas sobre la compatibilidad de cualquiera de sus leyes internas, y la Convención Americana sobre Derechos Humanos o los «otros tratados», cuyo alcance hemos definido anteriormente.

A la Corte Interamericana se le presentó en dos oportunidades diferentes la posibilidad de decidir sobre si puede emitir opinión sobre la compatibilidad en materia de derechos humanos, de proyectos legislativos (es decir, leyes aún no sancionadas).

En ambos casos, ha sido el gobierno de Costa Rica quien formuló el pedido de Opinión Consultiva. En la última de las situaciones, la Corte ha decidido no contestar la pregunta por entender que bajo una consulta, se le estaba pidiendo opinión anticipada de casos que se tramitaban ante la Comisión, y serían de probable futura competencia contenciosa del Tribunal 519.

En el primero de los casos, el Estado de Costa Rica iba a proceder a la modificación de su Constitución Nacional. Al poseer dudas sobre algunas de las reformas propuestas, preguntó si ellas eran compatibles con la Convención Americana sobre Derechos Humanos.

La Corte Interamericana debió decidir, con carácter previo, si era competente para rendir en Opinión Consultiva, un dictamen sobre un proyecto de legislación y no sobre legislación ya sancionada.

La Corte, si bien en la parte dispositiva no hace mención a la cuestión (pero sí contesta a las preguntas formuladas, lo cual habla de un asentimiento tácito de la parte dispositiva), finalmente sostuvo en sus considerandos: «...siempre que un convenio internacional se refiera a leyes internas sin calificar en forma alguna esta expresión o sin que de su contexto resulte un sentido más restringido, la referencia es para toda legislación nacional y para todas las normas jurídicas de cualquier naturaleza, incluyendo disposiciones constitucionales...» «...Abstenerse, en consecuencia, de atender la solicitud de un gobierno porque se trate de «proyectos de ley» y no de leyes formadas y en vigor, podría, en algunos casos, equivaler a forzar a dicho gobierno a la violación de la Convención, mediante la adopción formal y posiblemente la aplicación de la medida legislativa, para luego acudir a la Corte en busca de la opinión. Este criterio no ayuda a «dar efecto» a la norma, es decir, no ayuda a la protección de los derechos y libertades fundamentales de los seres humanos» $\mathbf{5 2 0}$.

Quisiéramos remarcar algunos párrafos, escogidos de resoluciones de la Corte Interamericana de Derechos Humanos, que dan un mayor fundamento a la formulación del Postulado que sostenemos, comenzando por la naturaleza de la propia función consultiva. «... Debe tenerse presente, asimismo, que la jurisdicción consultiva fue establecida por el artículo 64 como un servicio que la Corte está 
en condiciones de prestar a todos los integrantes del sistema interamericano, con el propósito de coadyuvar al cumplimiento de sus compromisos internacionales referentes a derechos humanos...» 521 .

Asimismo, señaló el Tribunal que el proceso consultivo «... está destinado a ayudar a los Estados y órganos a cumplir y aplicar tratados en materia de derechos humanos, sin someterlos al formalismo y al sistema de sanciones que caracteriza el proceso contencioso $\mathbf{5 2 2}$.

Los dos siguientes párrafos describen perfectamente la postura sostenida por la Corte Interamericana de Derechos Humanos, respecto al alcance de su función consultiva:

«... El artículo 64 de la Convención confiere a esta Corte la más amplia función consultiva que se haya confiado a tribunal internacional alguno hasta el presente...» $\mathbf{5 2 3}$.

«... En la concepción del artículo 64 del Pacto de San José, en cambio, no se considera excluida expresamente ninguna materia concerniente a la protección de los derechos humanos en los Estados americanos.... 524 .

Lo anterior no debe llevarnos, sin embargo, a considerar que la función consultiva de la Corte Interamericana no tiene límite alguno; ya que ninguna competencia de un órgano de protección de los derechos humanos, puede ser autónoma del sistema que le contiene.

Así, el criterio general sostenido por la Corte Interamericana es que «... la función consultiva hay que entenderla con criterio amplio, encaminado también a hacer efectivos tales derechos y libertades...» 525 .

El mismo Tribunal, ha delineado los márgenes que la Corte no puede trasvasar, en la competencia que le atribuye el artículo 64 de la Convención Americana de Derechos Humanos.

En este sentido, la Corte sostuvo que: «... La amplitud de los términos del artículo 64 de la Convención no puede, sin embargo, confundirse con la ausencia de límites a la función consultiva de la Corte...» 526 .

Un primer criterio reductivo general, es el objeto y fin del Pacto de San José de Costa Rica: «... La función consultiva de la Corte no puede desvincularse de los propósitos de la Convención. Dicha función tiene por finalidad coadyuvar al cumplimiento de las obligaciones internacionales de los Estados americanos en lo que concierne a la protección de los derechos humanos...» 527 .

Otros límites, que se derivan del anterior, son la propia posibilidad de actuación en competencia contenciosa de la Corte, y la protección de los derechos de aquellos que podrían haber sufrido violaciones a los derechos humanos: así la Corte Interamericana sostuvo que: «... Sería inadmisible toda solicitud de consulta que conduzca a desvirtuar la jurisdicción contenciosa de la Corte, o en general, a debilitar o alterar el sistema previsto por la Convención, de manera que puedan verse menoscabados los derechos de las víctimas de eventuales violaciones de los derechos humanos...» 528 .

Aunque volveremos sobre ello en el Capítulo IX, como podemos observar, la Corte se vale de una competencia consultiva de dimensiones excepcionales, pero sin perder de vista el objetivo de la Convención Americana. «... De acuerdo con la Opinión [ se refiere a la Opinión Consultiva 1 ] la Corte ha considerado que la Convención Americana sobre Derechos Humanos ha querido dar a la Corte Interamericana de Derechos Humanos una competencia lo más amplia posible y que establecer una limitación a ese propósito en materias concernientes a los derechos humanos constituiría una limitación a la plena garantía de éstos...» $\mathbf{5 2 9}$.

Si bien esta opinión de Juan Antonio Travieso da el criterio general, el mismo debe leerse a la luz de los límites señalados y examinados en el presente acápite.

2.- Cuando se dan ciertos requisitos, la Comisión debería considerar especialmente, la posibilidad de llevar un caso contencioso ante la Corte Interamericana de Derechos Humanos

La Corte Interamericana no se ha referido en varias oportunidades a esta cuestión; sin embargo, por la trascendencia de la materia, nos parece importante destacar los párrafos de una Opinión Consultiva, en la que ha abordado el asunto.

Tal como hemos visto en el Capítulo IV, los individuos no están facultados para llevar un caso ante la Corte, sino que la legitimación activa en este sentido, la poseen la Comisión Interamericana 
y los Estados: «...Sólo los Estados Partes y la Comisión tienen derecho a someter un caso a la decisión de la Corte...» 530 .

Nuestro objeto de atención en este punto, no se focaliza en la legitimación activa del individuo ante la Corte Interamericana, sino en si existe absoluta discrecionalidad para la Comisión Interamericana, en decidir cuando debe enviar a la Corte un caso que ha tramitado en su seno, para que esta última ejerza su jurisdicción contenciosa.

Naturalmente, un pre requisito ineludible, es que el Estado demandado debe haber ratificado el Pacto de San José de Costa Rica, y haber aceptado la jurisdicción de la Corte Interamericana en materia contenciosa.

Pero cabe preguntarse en primer lugar, si existe una verdadera obligación para la Comisión Interamericana, de enviar un caso para su tratamiento en la Corte.

De la letra del artículo 61 del Pacto de San José de Costa Rica que hemos transcripto, no caben dudas que enviar un caso a la Corte es una atribución facultativa para la Comisión Interamericana, sujeta a ciertos requisitos formales: a la ya mencionada aceptación de la competencia de la Corte, deben haberse tramitado los pasos pertinentes, ante la Comisión Interamericana de Derechos Humanos 531 .

Ahora bien, siendo facultativa esta decisión de la Comisión Interamericana ¿es arbitraria? Es decir, puede la Comisión enviar o no casos a la Corte según su antojo?

Analizando los artículos 50 y 51 de la Convención, Dunshee de Abranches considera que existe un criterio para que la Comisión tome una decisión. El autor considera que hay unas pautas, para considerar cuando debe enviarse un caso a la Corte, pero no criterios que obliguen a la Comisión a realizar ese envío.

El autor sostiene que «...resulta de estas premisas la conclusión lógica de que el criterio que habrá de adoptarse en cada caso, para la Comisión deliberar sobre la sumisión del asunto a la Corte, es la existencia de alguna duda fundada en cuanto a la interpretación o aplicación de la Convención a los hechos expuestos en el informe de la Comisión...» 532.

Edith Márquez Rodríguez menciona, que en la práctica llevada adelante por la Comisión Interamericana, ésta «...ha ido precisando ciertos elementos mínimos para que un caso pueda ser sometido al tribunal de San José. Todos ellos surgen de la interpretación que la Comisión ha hecho de la Convención...», destacando a posteriori, la aceptación de la jurisdicción contenciosa de la Corte por parte del Estado, el agotamiento del procedimiento ante la Comisión Interamericana y que la Comisión haya considerado que existió una violación a la Convención $\mathbf{5 3 3}$.

Como la misma autora reconoce, la Corte Interamericana de Derechos Humanos no comparte este último requisito, tal como queda demostrado por la selección de jurisprudencia que realizamos en el presente acápite.

Pero algunos reconocidos analistas y prácticos en el sistema interamericano, como Juan Méndez, las reglas mencionadas por Marquez Rodríguez no constituyen criterios a partir de los cuales se pueda deducir que un caso va a ser enviado a la Corte Interamericana sino «requisitos mínimos» 534 .

La Corte se ha referido al asunto, con cierto grado crítico a la actuación de la Comisión Interamericana. En la cuestión de la colegiación obligatoria de periodistas, sostuvo: «... Aunque la Convención no especifica bajo que circunstancias la Comisión debe referir un caso a la Corte, de las funciones que asigna a ambos órganos se desprende que, aún cuando no esté legalmente obligada a hacerlo, hay ciertos casos que, al no haberse podido resolver amistosamente ante la Comisión, deberían ser sometidos por ésta a la Corte. El caso Schmidt cae ciertamente dentro de esta categoría. Se trata de un caso que plantea problemas legales controversiales no considerados por la Corte; su trámite en la jurisdicción interna de Costa Rica fue objeto de decisiones judiciales contradictorias; la propia Comisión no pudo alcanzar una decisión unánime sobre esos problemas jurídicos; y es una materia que reviste especial importancia en el continente, donde varios Estados han apoyado leyes parecidas a la de Costa Rica» «... Dado que los individuos no están legitimados para introducir una demanda ante la Corte y que un gobierno que haya ganado un asunto ante la Comisión no tiene incentivo para hacerlo, la determinación de esta última de someter un caso semejante a la Corte, 
representa la única vía para que operen plenamente todos los medios de protección que la Convención establece. Por ello, la Comisión está llamada a considerar especialmente la posibilidad de acudir a la Corte» $\mathbf{5 3 5}$.

Juan Méndez, en el estudio citado, destaca que el envío de un caso a la Corte Interamericana reviste una importancia fundamental que no tiene equivalente en el sistema europeo, y describe criterios apuntados por la doctrina, entre los que figuran los «requisitos mínimos», un criterio formal sobre la calidad de la prueba, y otros de tipo material, entre los que se cuentan la importancia de los derechos violados, la magnitud de la violación de la regla violada en torno a la legislación imperante en otros Estados del hemisferio, la importancia de los derechos medida en relación a ciertas categorías de personas que podrían beneficiarse de una jurisprudencia favorable a las víctimas, la óptima protección del derecho a través de la tutela del caso por la misma Corte, la necesidad de una decisión judicial de la Corte que confirme la práctica de la Comisión, o alternativamente, la necesidad de dotar la posibilidad a la Corte de cambiar su propia jurisprudencia en una cuestión particular, y por último, la novedad del caso $\mathbf{5 3 6}$.

Cabe decir entonces, que si bien la Comisión Interamericana de Derechos Humanos tiene la prerrogativa discrecional de enviar un caso a la Corte Interamericana de Derechos Humanos, esa discrecionalidad no es absoluta.

El aporte realizado por el Tribunal a la cuestión, radica en su postura de que aunque la decisión final caiga sobre la misma Comisión Interamericana, ésta debe ponderar algunas circunstancias y características del asunto, sobre las que debe apoyar la decisión sobre el envío o no de un caso contencioso, al entendimiento de la Corte Interamericana de Derechos Humanos.

\section{3.- La desaparición forzada de personas, es una forma compleja de violación de varios derechos fundamentales}

La Guerra Fría, que libraron en todo el mundo los Estados Unidos y la ex - Unión Soviética a partir de 1945, ha profundizado un conflicto ideológico, que ha sido germen de uno de los flagelos más graves a los que se enfrenta la sociedad mundial en la actualidad, en materia de derechos humanos: nos referimos a la práctica sistemática de la desaparición forzada de personas como medio político de represión.

La intolerancia, el no respeto al otro y el predominio de los fines por sobre los medios, han llevado a muchos gobiernos a escribir una página vergonzosa a partir de la década de 1970, cuando opositores políticos, obreros, estudiantes o personas que simplemente no estaban de acuerdo con sus ideas, «desaparecían» misteriosamente: Tal como agudamente señala Mónica Pinto en un trabajo dedicado al tema, «... la desaparición forzada de personas es un expediente rápido para erradicar elementos molestos en un contexto autocrático...» 537 .

La desaparición forzada constituye una modalidad represiva, que atenta contra varios de los derechos y libertades consagrados en los textos internacionales como «derechos humanos»: bástenos mencionar a la libertad, el derecho a defensa de toda acusación, la presunción de inocencia, las garantías judiciales y la identidad. Pero también, la desaparición forzada es acompañada de una acción que, invariablemente lesiona los derechos a la integridad corporal, a no ser sometido a torturas y, en muchos casos, el derecho a la vida. De la misma forma, al negar los gobiernos toda información sobre el paradero de las víctimas, dejan a éstas y a sus familiares en un total estado de indefensión. «... Estas medidas tendrán un efecto intimidatorio, porque los prisioneros se desvanecerán sin dejar rastro; y no podrá darse información alguna respecto a su paradero o su suerte...» $\mathbf{5 3 8}$.

Cuando la Corte Interamericana de Derechos Humanos debió enfrentarse a los primeros casos que versaban sobre desaparición forzada de personas, se encontró que no existía ningún tratado internacional vigente en la materia. A partir de allí, el Tribunal debió realizar una inteligente construcción jurídica para tipificar esa práctica aberrante, conforme a los derechos consagrados en la Convención Americana sobre Derechos Humanos. 
Así, el Tribunal, en el entendimiento de la cuestión, ha señalado que «...El fenómeno de las desapariciones constituye una forma compleja de violación de los derechos humanos que debe ser comprendida y encarada de una manera integral...» 539 .

En la Organización de Naciones Unidas, la desaparición forzada ha tenido un tratamiento especial, que no ha concluido aún con la adopción de una Convención sobre el tema. Los avances han llegado hasta la creación de un Grupo de Trabajo sobre desapariciones forzadas o involuntarias, conforme a los procedimientos extraconvencionales que hemos descrito en el Capítulo III 540 .

Las actividades del Grupo de Trabajo se desarrollan en tres niveles: se ocupa de casos individuales (recibe denuncias de familiares u organismos de derechos humanos y se comunican con los gobiernos presionando a éstos para que investiguen y comuniquen su resultado al Grupo); estudia la situación de desapariciones en diversos países, y finalmente, dedica su atención al fenómeno de las desapariciones en su integridad, la incidencia en el universo de los derechos humanos, sus causas y efectos. Se reúne tres veces al año y tiene entre otras competencias la facultad de enviar misiones a países (con la aceptación de los respectivos gobiernos) 541 .

Es necesario señalar aquí que dentro del ámbito de las Naciones Unidas, los gobiernos han sido reacios a adoptar normas jurídicas por medio de las cuales pueda señalárseles responsabilidad en las violaciones a los derechos humanos por hechos de desaparición forzada. Recién en diciembre de 1992, se ha adoptado una Declaración por parte de la Asamblea General 542.

La Corte Interamericana de Derechos Humanos, ha hecho mención al tratamiento dado a las desapariciones forzadas dentro de algunos órganos de las Naciones Unidas, y de la propia Asamblea General de la Organización de los Estados Americanos; y también señaló que: «... la doctrina y la práctica internacionales han calificado muchas veces las desapariciones como un delito contra la humanidad... La Asamblea de la OEA ha afirmado que «es una afrenta a la conciencia del Hemisferio y constituye un crimen de lesa humanidad...» 543.

La Conferencia mundial de Derechos Humanos celebrada en junio de 1993 en Viena (Austria), no otorgó la importancia debida a la cuestión de las desapariciones: «... La cuestión de la desaparición forzada ha sido menospreciada en el documento: se encuentra dentro del capítulo de la tortura y si bien, la desaparición generalmente acarrea torturas, es un delito de suficiente gravedad como para dedicarle algo más que un párrafo...»544

El documento emanado de la Conferencia Mundial (Declaración y Programa de Acción de Viena), tan sólo reafirma que es obligación de los Estados, emprender una investigación siempre que haya motivos, para creer que se ha producido una desaparición forzada en un territorio sujeto a su jurisdicción y, si se confirman las denuncias, enjuiciar a los responsables del hecho $\mathbf{5 4 5}$.

Sobre el vínculo entre la desaparición forzada y el Pacto de San José de Costa Rica, la Corte Interamericana ha sido tajante, al señalar que «... La práctica de desapariciones... significa una ruptura radical de este tratado, en cuanto implica el craso abandono de los valores que emanan de la dignidad humana $\mathrm{y}$ de los principios que más profundamente fundamentan el sistema interamericano y la misma Convención...» 546.

Nieto Navia subraya que la desaparición forzada de personas «... no está tipificada como una violación de la Convención con ese nombre...» (el autor se refiere al Pacto de San José de Costa Rica) 547 . Esto no obsta a que la desaparición forzada, como la propia Corte Interamericana ha dicho, sea una violación indudable del pacto de San José de Costa Rica, no sólo puntualmente en cuanto a algunos derechos consagrados en el mismo, sino también al objeto y fin del tratado.

La Corte Interamericana ha abordado la cuestión de la siguiente manera: «... La desaparición forzada de seres humanos constituye una violación múltiple y continuada de numerosos derechos reconocidos en la Convención y que los Estados Partes están obligados a respetar y garantizar...» 548 .

La Corte ha hecho muchas consideraciones, sobre cuáles son los derechos que son lesionados con la práctica de la desaparición forzada, partiendo de la libertad personal.

Las relaciones entre las violaciones al derecho a la integridad personal (no ser sometido a torturas) y la desaparición forzada de personas son casi indisolubles: Amnistía Internacional había señalado ya en un estudio especial realizado al efecto y publicado en 1984, que «... La 
incomunicación, la detención, el lugar secreto y la desaparición, pone a los agentes de seguridad en una situación de control absoluto de la vida y de la integridad física de los detenidos...» 549 .

En el mismo sentido, la Corte Interamericana de Derechos Humanos ha sostenido al resolver los primeros asuntos sobre desaparición forzada de personas, que «... el aislamiento prolongado y la incomunicación coactiva a los que se ve sometida la víctima representan, por sí mismos, formas de tratamiento cruel e inhumano, lesivas de la integridad psíquica y moral de la persona y del derecho de todo detenido al respeto debido a la dignidad inherente al ser humano...» $\mathbf{5 5 0}$.

Particularmente descriptiva, la Corte Interamericana también ha dicho que «... ella [ refiriéndose a la desaparición forzada ] incluye el trato despiadado a los detenidos, quiénes se ven sometidos a todo tipo de vejámenes, torturas y demás tratamientos crueles, inhumanos y degradantes, en violación también al derecho a la integridad física...» $\mathbf{5 5 1}$.

En relación al derecho a la vida y las desapariciones forzadas, la Corte Interamericana sostuvo que «... La práctica de las desapariciones, en fin, ha implicado con frecuencia la ejecución de los detenidos, en secreto y sin fórmula de juicio, seguida del ocultamiento del cadáver con el objeto de borrar toda huella material del crimen y de procurar la impunidad de quiénes lo cometieron, lo que significa una brutal violación del derecho a la vida...» $\mathbf{5 5 2}$.

La jurisprudencia de la Corte Interamericana respecto de la desaparición forzada es la más extensa que posee el tribunal en materia contenciosa, debido también al esfuerzo que ha debido hacer el juzgador para elaborar una doctrina sobre dicha práctica, en relación a la protección de los derechos humanos en el sistema interamericano, y particularmente en el marco del Pacto de San José de Costa Rica.

Tal como hemos mencionado en el Capítulo III, existe en el sistema interamericano desde 1994, la Convención Interamericana sobre Desaparición Forzada de Personas, adoptada en la Asamblea General de la Organización de los Estados Americanos celebrada en Belem do Pará, Brasil.

Esta Convención define finalmente a la desaparición forzada de la siguiente manera: «... para que exista desaparición forzada de una persona se requiere: a) Que se haya privado de la libertad a una persona de cualquier forma; b) Que esa privación de libertad haya sido ejecutada por agentes del Estado o personas o grupos de personas que actúen con su autorización, apoyo o aquiescencia; c) Que la privación de la libertad haya sido seguida de la falta de información o negativa a reconocer la privación de la libertad o de informar sobre el paradero de la persona; y d) Que a consecuencia de lo anterior se haya impedido a la persona ejercer los recursos legales y las garantías procesales pertinentes» $\mathbf{5 5 3}$.

Una de las consecuencias más penosas que rodean la desaparición forzada, está configurada por la sustracción de menores (hijos de desaparecidos) del seno de sus familias biológicas. La Convención determina que los Estados deben cooperar en buscar, identificar, localizar y restituir a menores que han sufrido la desaparición forzada de sus padres, tutores o guardadores 554 .

La Convención, entre sus disposiciones principales, también descarta la posibilidad de alegar como eximente de responsabilidad a la obediencia debida $\mathbf{5 5 5}$.

La Convención Interamericana sobre Desaparición Forzada de Personas (1994), ha recogido varios de los principios que surgen de la jurisprudencia que ha construido la Corte Interamericana de Derechos Humanos.

Así, determina que la Desaparición Forzada constituye un crimen de lesa humanidad, (uno de los aspectos que más se ha discutido en el seno de la Organización de los Estados Americanos a la hora de adoptar el texto). También señala que la desaparición forzada de personas viola múltiples derechos esenciales de la persona humana de carácter inderogable, tal como están consagrados en la Convención Americana sobre Derechos Humanos, en la Declaración Americana de los Derechos y Deberes del Hombre, y en la Declaración Universal de los Derechos Humanos 556.

El Postulado que emerge de la jurisprudencia de la Corte en la cuestión que nos ocupa, ha indicado el camino que debía seguir la norma convencional que tipificó a la desaparición forzada de personas en el hemisferio americano. 


\section{4.- Los hijos menores de víctimas de violaciones al derecho a la vida, deben tener asegurado especialmente su derecho a la educación}

Uno de los Postulados más significativos de creación pretoriana de la Corte Interamericana de Derechos Humanos, construído fundamentalmente a través de su competencia contenciosa, es el que pasamos a examinar bajo el presente acápite.

El derecho a la educación, considerado uno de los derechos sociales y culturales, ya se encontraba consagrado en diferentes instrumentos internacionales de derechos humanos 557 .

La Declaración Universal de los Derechos Humanos destaca el derecho a la educación, dándole las características de gratuita y obligatoria para el nivel de instrucción elemental, generalizada para la instrucción técnica y profesional, e igual para todos en relación a los estudios superiores 558 .

La Declaración de los Derechos del Niño, menciona que éste tiene derecho a recibir educación que será gratuita y obligatoria por lo menos en las etapas elementales, es decir, agrega un criterio de progresividad al señalar un mínimum pero no un máximo sobre la gratuidad y la obligatoriedad 559

El Pacto Internacional de Derechos Económicos, Sociales y Culturales, recoge lo expresado por la Declaración Universal de los Derechos Humanos, y agrega respecto a la enseñanza superior, que los Estados deben implantar progresivamente la gratuidad 560 .

Finalmente, la Convención de los Derechos del Niño recepta y desarrolla también, el Principio VII de la Declaración de los Derechos del Niño a que hemos hecho referencia 561.

Como vemos, el derecho a la educación no es creación pretoriana de la Corte Interamericana de Derechos Humanos; sin embargo, la jurisprudencia de la Corte complementa un aspecto del derecho a la educación, para determinadas personas cuyos progenitores hayan sufrido violación al derecho a la vida, en una acción imputable directa o indirectamente al Estado.

En algunas ocasiones, las víctimas de violaciones al derecho a la vida, en casos tramitados por la Corte Interamericana de Derechos Humanos, poseían hijos en edad de realizar sus estudios; esta cuestión, motivó la consagración del Postulado enunciado, derivado del propio estado de vulnerabilidad que la situación engendra a la familia de la víctima.

La Corte Interamericana ha implementado la aplicación de este Postulado en lo atinente a las reparaciones, teniendo en cuenta que no son las propias víctimas quiénes reciben la indemnización, sino sus derecho habientes.

Así, la Corte ha dicho que: «... Si los beneficiarios de la indemnización son los familiares, la cuestión se plantea en términos distintos. Los familiares tienen, en principio, la posibilidad actual o futura de trabajar o tener ingresos por sí mismos. Los hijos, a los que debe garantizarse la posibilidad de estudiar hasta una edad que puede estimarse en los veinticinco años, podrían, por ejemplo, trabajar a partir de ese momento...» 562 .

En estos casos, la Corte Interamericana ha dispuesto la creación de un fideicomiso que tendrá por función la administración de una suma de dinero, con el propósito de que los hijos de las víctimas completen sus estudios «... Con la suma atribuida a los hijos se constituirá un fideicomiso en el Banco Central de Honduras, en las condiciones más favorables según la práctica bancaria hondureña. Los hijos recibirán mensualmente los beneficios de este fideicomiso y al cumplir los veinticinco años de edad percibirán la parte alícuota que les corresponda...» 563 .

Un importante fallo de la Corte Interamericana de Derechos Humanos, ha atendido a la circunstancia particular del caso en un asunto de detención arbitraria, torturas y ejecuciones extrajudiciales de varios indígenas habitantes de Suriname, determinando para administrar la indemnización, un fideicomiso para menores y mayores, creando además una fundación al efecto 564 .

Esta concepción de reparación es alentadora, y ayuda a un alcance amplio de la protección de los derechos humanos en América; asimismo, garantiza que los hijos de víctimas de violaciones tan graves a los derechos humanos, adquieran una herramienta útil para su vida posterior.

Ha ido más allá el Tribunal con la obligación del Estado respecto a garantizar este Postulado que enunciamos, ya que por primera vez, ha introducido en su sentencia obligaciones de hacer para el Estado en cuestión: «... En la indemnización fijada para los herederos de las víctimas se ha previsto 
una suma para que los hijos menores puedan estudiar hasta una determinada edad. Sin embargo, estos objetivos no se logran sólo otorgando una indemnización, sino que es preciso, también que se ofrezca a los niños una escuela donde puedan recibir una enseñanza adecuada y una asistencia médica básica. En el momento actual, ello no ocurre en varias aldeas saramacas ... Los hijos de las víctimas viven, en su mayoría, en Gujaba, donde la escuela y el dispensario están cerrados. La Corte considera que, como parte de la indemnización, Suriname está obligado a reabrir la escuela de Gujaba y dotarla de personal docente y administrativo para que funcione permanentemente a partir de 1994. Igualmente, se ordenará que el dispensario allí existente sea puesto en condiciones operativas y reabierto en el curso de este año...» 565 .

En la parte resolutiva de la sentencia que nos encontramos analizando, se ordenan estas obligaciones de hacer para el Estado: «... La Corte... Ordena al Estado de Suriname, igualmente, con carácter de reparación, reabrir la escuela sita en Gujaba y dotarla de personal docente y administrativo para que funcione permanentemente a partir de 1994 y poner en operación en el curso de ese año el dispensario existente en el lugar...» 566 .

De la jurisprudencia emitida por la Corte Interamericana de Derechos Humanos, podemos colegir que ésta, en todos los casos que ha encontrado pleno responsable al Estado de la violación del derecho a la vida, y siempre que las víctimas tuvieren hijos menores, ha establecido la obligación para el Estado de otorgar una suma de dinero destinada a que los hijos puedan estudiar hasta la edad de 25 años, ampliando de manera pretoriana el alcance de la posibilidad de hacer efectivo el derecho a la educación para aquellos.

Como medida para hacer efectiva esta decisión, la Corte ha ordenado la creación de fideicomisos en los bancos centrales locales, en las condiciones más favorables según la práctica bancaria del país, para que los hijos de las víctimas puedan recibir los beneficios de dicho fideicomiso mensualmente, y la parte alícuota que le corresponda a cada uno de ellos al cumplir los 25 años.

A nuestro juicio, la Corte Interamericana de Derechos Humanos ha iniciado la sana jurisprudencia de obligar al Estado, además de a efectuar la indemnización pecuniaria correspondiente, a realizar ciertas actividades o prestaciones como parte integrante de la indemnización dispuesta. 


\section{CAPITULO IX}

\section{CONSIDERACIONES FINALES}

Sumario: I.: En cuanto a las relaciones entre el Derecho Internacional Público y el Derecho Internacional de los Derechos Humanos; II.- En cuanto a la protección internacional y regional de los derechos humanos, sus instituciones, órganos y procedimientos; III.- En cuanto a la Corte Interamericana de Derechos Humanos, sus competencias y asuntos resueltos; IV.- En cuanto a los Postulados emergentes de la jurisprudencia de la Corte Interamericana, tomados del Derecho Internacional Público; V.- En cuanto a los Postulados emergentes de la jurisprudencia de la Corte Interamericana, tomados del Derecho Internacional de los Derechos Humanos; VI.- En cuanto a los Postulados emergentes de la jurisprudencia de la Corte Interamericana, de creación pretoriana del Tribunal.

\section{I.- En cuanto a las relaciones entre el Derecho Internacional Público y el Derecho Internacional de los Derechos Humanos}

01.- Las Organizaciones y normas internacionales, surgen en la historia como una forma de regular las relaciones internacionales de cada época, conforme a la distribución de poder en el escenario mundial.

02.- Algunas veces, situaciones sociales e históricas de magnitud, influyen en la conformación del Derecho Internacional Público, y provocan modificaciones profundas al mismo.

03.- La Segunda Guerra Mundial trajo aparejada la formación de un nuevo paradigma en las relaciones internacionales, y la conformación de Organizaciones Internacionales a nivel mundial y regional, para mantener la paz y seguridad internacionales.

04.- Los crímenes de lesa humanidad, cometidos por el fascismo y el nazismo, han marcado la exigencia de la comunidad internacional para tomar medidas fuera de las fronteras de un Estado, cuando se dan los extremos señalados, naciendo de esta forma el Derecho Internacional de los Derechos Humanos.

05.- La protección internacional de los derechos humanos posee cuatro características, desde el punto de vista de las relaciones internacionales contemporáneas.

06.- La primera característica es la internacionalización de la protección de los derechos humanos. Esta ha dejado de estar bajo la esfera de los Estados nacionales, y la competencia en la materia, es ahora compartida entre los Estados y la comunidad internacional.

07.- Como consecuencia de lo anterior, el principio de no intervención y la soberanía nacional no pueden ser argumentos válidos de los gobiernos, frente a trámites que se encuentren establecidos en su contra por violaciones a los derechos humanos, que se lleven adelante dentro de las Organizaciones Internacionales de las que su Estado sea integrante.

08.- La segunda característica de la protección internacional de los derechos humanos es la subsidiariedad. A pesar de la concurrencia de las competencias nacional e internacional en materia de derechos humanos, quien tiene prelación en el entendimiento de los casos es el Estado Nacional, y la puesta en marcha de un mecanismo internacional es subsidiaria. Es por ello, que los mecanismos internacionales de protección de los derechos humanos exigen como regla el agotamiento de los recursos internos, un pre requisito para el acceso a la vía internacional.

09.- Como tercera característica de la protección internacional de los derechos humanos se señala la irrenunciabilidad. Las Organizaciones Internacionales, por fundamentaciones éticas, no pueden declinar su jurisdicción, cuando estén habilitadas para tramitar casos de violaciones a los derechos humanos. 
10.- La última característica de la protección internacional de los derechos humanos es la progresividad, explicada actualmente por los nuevos conceptos de derechos humanos que pueden observarse en cuanto al objeto, y por la cada vez más creciente legitimidad internacional del individuo.

11.- Asimismo, la progresividad en la materia puede observarse por la tendencia actual hacia la creación de nuevos instrumentos, órganos y procedimientos de protección, en las Organizaciones Internacionales a nivel mundial y regional.

12.- El Derecho Internacional de los Derechos Humanos influye en los conceptos tradicionales del Derecho Internacional: la soberanía estatal y el dominio reservado de los Estados pasan a tener contornos nuevos, en la comprensión del fenómeno protectivo.

13.- El Derecho Internacional de los Derechos Humanos fue creando, de a poco, la subjetividad jurídico internacional del individuo, a través de instrumentos jurídicos que le otorgan a aquel la posibilidad de acudir ante un órgano internacional, para defender sus derechos y libertades fundamentales. Existen normas de este tipo - con mayor, menor o ningún grado de acción para el individuo - en Naciones Unidas, la Liga de Estados Arabes, la Organización de la Unidad Africana, el Consejo de Europa, la Comunidad de Estados Independientes y la Organización de los Estados Americanos. También el individuo puede ser acusado ante una instancia internacional (hoy existen los tribunales ad hoc para Rwanda y la Ex Yugoslavia), aunque el desarrollo en este campo es mucho menor, y no existe aún una Corte Penal Internacional Permanente, a pesar de los avances en la discusión del tema, dentro de la Agenda de la Asamblea General de las Naciones Unidas.

14.- El Derecho Internacional de los Derechos Humanos introduce algunas modificaciones al Derecho Internacional convencional o «derecho de los tratados».

15.- En cuanto a la exigibilidad legal, ciertas declaraciones de derechos humanos son jurídicamente obligatorias, y el incumplimiento de algunas de sus normas genera responsabilidad internacional para el Estado infractor.

16.- Existen normas de derechos humanos que han adquirido la categoría de ius cogens. Estas se encuentran en preceptos internacionales inderogables, constituyendo un núcleo duro que forma parte del orden público internacional.

17.- En la posguerra fría han surgido encuentros internacionales sobre temáticas globales, en las cuales los derechos humanos han sido materia central, u ocupado una parte importante del debate producido en esos foros.

18.- En estas «megaconferencias» se adoptaron instrumentos jurídicos (llamados generalmente declaraciones o planes de acción), que fueron adoptados por el consenso de los Estados participantes.

19.- Dichos instrumentos constituyen hoy fuentes subsidiarias del Derecho Internacional, contienen disposiciones que ya forman parte del Derecho Internacional de los Derechos Humanos, y otros preceptos que pueden devenir costumbres jurídicas, o consolidarse en un convenio.

\section{II.- En cuanto a la protección internacional y regional de los derechos humanos, sus instituciones, órganos y procedimientos}

20.- Las necesidades señaladas en el acápite anterior, dieron lugar a la conformación de sistemas protectivos de derechos humanos, a nivel internacional y regional, que poseen diferente nivel de desarrollo, debido a factores tales como la composición, grado de democratización, tradición jurídica, etc.

21.- La protección internacional y regional no es incompatible, sino complementaria y no excluyente.

22.- La universalidad en materia de derechos humanos puede subsistir y no verse amenazada por el regionalismo, si se toma en cuenta para la resolución de los casos la regla «pro homine»; y, finalmente, hay una cláusula de salvaguarda en el artículo 103 de la Carta de las Naciones Unidas, que puede ser aplicada para el mantenimiento de un standard mínimo de protección. 
23.- En la Liga de los Estados Arabes existe un instrumento de protección (la Carta Arabe de Derechos Humanos), cuya eficacia es débil, debido a la falta de voluntad política de los Estados en ratificarla, y al tipo de sistema protectivo incluido en su seno.

24.- En el Consejo de Europa se encuentra el sistema más evolucionado de protección de los derechos humanos, en particular por los mecanismos desarrollados para la tutela de los derechos y libertades fundamentales.

25.- En la Organización de la Unidad Africana, la Carta Africana de Derechos Humanos y de los Pueblos es un instrumento jurídico que, en la materia, introduce el concepto de "Derechos de los Pueblos» por primera vez en un convenio marco regional. Su mecanismo de protección no posee gran eficacia aún.

26.- En la Comunidad de los Estados Independientes se adoptó la Convención de Minsk sobre Derechos y Libertades Fundamentales del Hombre. Como uno de los problemas de dicho Pacto, puede subrayarse la extrema amplitud que poseen los Estados para proceder a la suspensión de derechos y garantías.

27.- En la Organización de los Estados Americanos se desarrolla progresivamente la protección de los derechos humanos, a través de la adopción de nuevos pactos sobre asuntos específicos, o protocolos anexos a la Convención Americana sobre Derechos Humanos, uno de los dos principales instrumentos para el continente.

28.- El sistema protectivo de derechos humanos en la Organización de los Estados Americanos, se encuentra atravesando por una etapa de perfeccionamiento.

29.- El avance normativo experimentado en las Organizaciones Internacionales, en materia de derechos humanos, ha sido seguido por el desarrollo de órganos y mecanismos de protección, encargados de controlar el cumplimiento por los Estados de los instrumentos jurídicos consagrados.

30.- En el estado actual del Derecho Internacional, los derechos civiles y políticos cuentan con mecanismos de protección internacional, que son más exigentes y eficaces que para la tutela de los derechos económicos, sociales y culturales.

31.- La protección de los derechos humanos puede dividirse en convencional y extraconvencional. A su vez, la primera posee mecanismos no contenciosos, cuasicontenciosos y contenciosos.

32.- Los mecanismos no contenciosos son los más comunes dentro del Derecho Internacional de los Derechos Humanos, y su fundamento se encuentra en el concepto de cooperación internacional.

33.- El ejemplo típico de los mecanismos no contenciosos es el sistema de informes, que está en varios convenios dentro de la Organización de las Naciones Unidas, y a nivel regional en la Carta Arabe de Derechos Humanos, y en la Carta Africana de Derechos Humanos y de los Pueblos.

34.- En los mecanismos cuasi contenciosos se busca identificar una violación determinada de derechos humanos, y disponer algún resarcimiento por tal hecho, cuando éste es imputable directa o indirectamente al Estado.

35.- Las quejas entre Estados se encuentran en algunos convenios de las Naciones Unidas, y en los sistemas africano, interamericano y europeo. Sin embargo, ha sido sólo en este último donde se conocen casos tramitados bajo esta posibilidad.

36.- Las comunicaciones individuales son procedentes en algunos instrumentos de las Naciones Unidas, en el Consejo de Europa, en la Organización de la Unidad Africana, y en el Sistema Interamericano.

37.- Este dispositivo tiene una enorme significación para el Derecho Internacional, desde el punto de vista de la subjetividad jurídico internacional del individuo.

38.- En comparación con el resto de los sistemas, el interamericano otorga la legitimación activa más amplia, para el acceso del individuo a la primera etapa de protección internacional.

39.- Los mecanismos contenciosos se tramitan ante órganos jurisdiccionales de derechos humanos. Existe actualmente la posibilidad de llevar adelante un procedimiento jurisdiccional contra un Estado, en materia de derechos humanos, en los sistemas europeo e interamericano. En cuanto a la Corte Internacional de Justicia de las Naciones Unidas, no puede considerarse un tribunal de derechos humanos con las mismas características que aquellas dos cortes regionales. 
40.- En el sistema europeo se observa una ampliación espectacular de la capacidad de actuar de la víctima o su representante ante el Tribunal Europeo de Derechos Humanos, particularmente a través del Protocolo IX, Anexo al Convenio Europeo (en vigor) y del Protocolo XI Anexo al Convenio Europeo (que entrará en vigor hacia fines de 1998).

41.- En el sistema interamericano, aunque el avance es más lento, en un proceso contencioso, la víctima o su representante ya gozan de «locus standi» para la etapa de reparaciones, ante la Corte Interamericana de Derechos Humanos.

42.- La protección extraconvencional nace como respuesta a determinados casos, a los que las convenciones de derechos humanos no otorgan solución. Dentro de la Organización de las Naciones Unidas, se utilizan para situaciones de violación masiva y flagrante de los derechos humanos dentro de un país, o para el estudio de un determinado fenómeno de derechos humanos en todo el mundo.

43.- Para llevar adelante la protección de los derechos humanos se crean órganos al efecto; éstos pueden ser de tipo administrativo o judicial. Se observa una mayor cantidad de entes administrativos que jurisdiccionales en las instituciones internacionales y regionales.

\section{III.- En cuanto a la Corte Interamericana de Derechos Humanos, sus competencias y asuntos resueltos}

44.- La Corte Interamericana de Derechos Humanos es un órgano jurisdiccional regional de protección de los derechos y libertades fundamentales, que funciona dentro de la Organización de los Estados Americanos.

45.- La Corte posee dos competencias principales de trabajo, llamadas consultiva y contenciosa.

46.- La función consultiva de la Corte Interamericana de Derechos Humanos es la más amplia que se conoce hasta el momento en el Derecho Internacional, tanto desde el punto de vista del objeto pasible de una consulta, como desde la legitimación activa para solicitarla.

47.- Comparada con el Tribunal Europeo de Derechos Humanos, la tarea consultiva llevada adelante por la Corte Interamericana de Derechos Humanos ha sido más profusa.

48.- En función contenciosa, la Corte entiende en casos contra Estados por presuntas violaciones a los derechos establecidos en el Pacto de San José de costa Rica.

49.- La función jurisdiccional de la Corte Interamericana de Derechos Humanos es de instancia única, no significando en ningún caso una vía de apelación, casación o revisión de la jurisdicción interna, o de la Comisión Interamericana de Derechos Humanos.

50.- De los veinticinco Estados Partes de la Convención Americana sobre Derechos Humanos, hay diecisiete que han aceptado la Competencia Contenciosa de la Corte Interamericana de Derechos Humanos.

51.- La Corte ha desarrollado una jurisprudencia muy rica, tanto en materia consultiva, como contenciosa, la cual da lugar a la sistematización de la misma a través de Postulados que emergen de su trabajo.

52.- La jurisprudencia de la Corte Interamericana de Derechos Humanos se ha basado en las obligaciones contraídas por los Estados miembros de la Organización de los Estados Americanos, en virtud de la Carta constitutiva de la OEA, y del artículo 1 de la Convención Americana, en cuanto estipula que los Estados Partes se comprometen a respetar los derechos y libertades reconocidos en la Convención Americana sobre Derechos Humanos, y a garantizar su libre y pleno ejercicio a toda persona que esté sujeta a su jurisdicción.

53.- Entendemos por Postulado emergente de la jurisprudencia de la Corte Interamericana de Derechos Humanos, un enunciado expreso o implícito que surge de las decisiones tomadas por dicho tribunal, y que configuren una línea de pensamiento substancial para la protección de los derechos humanos.

54.- Los Postulados se toman, ya sea por la reiteración de los mismos en distintas resoluciones, o por el grado de importancia para la protección de los derechos humanos, cuando se encuentran sólo en una decisión de la Corte Interamericana de Derechos Humanos.

55.- Clasificamos tres tipos de Postulados emergentes de la jurisprudencia de la Corte Interamericana de Derechos Humanos: los tomados de contenidos propios del Derecho 
Internacional general, los tomados de contenidos propios del Derecho Internacional de los Derechos Humanos, y aquellos que son creación pretoriana del Tribunal con sede en San José de Costa Rica.

\section{IV.- En cuanto a los Postulados emergentes de la jurisprudencia de la Corte Interamericana, tomados del Derecho Internacional Público}

56.- Los Postulados tomados del Derecho Internacional Público no se limitan a los principios del Derecho Internacional. Ellos pueden ser reglas convencionales, principios del Derecho Internacional, principios generales del derecho que adquieren la categoría de fuentes del Derecho Internacional, resoluciones de órganos internacionales, o bien, jurisprudencia de la Corte Internacional de Justicia, o de la Corte Permanente de Justicia Internacional.

57.- Primer Postulado: Los métodos de interpretación que utiliza la Corte Interamericana, son los mismos que posee el Derecho Internacional general.

58.- La Corte Interamericana de Derechos Humanos, para su trabajo, recurre a las reglas generales de interpretación, y a la utilización de medios complementarios, según está establecido en la Convención de Viena sobre Derecho de los Tratados de la Organización de las Naciones Unidas.

59.- No obstante, la Corte Interamericana de Derechos Humanos, por la propia naturaleza de los casos que le tocó resolver, ha acercado más el criterio teleológico (interpretación conforme al objeto y fin) al exegético (texto literal), pero sin dejar de considerar la preeminencia de este último. Esta flexibilidad de la Corte Interamericana, tiene como fundamento no debilitar el sistema de protección consagrado en la Convención Americana sobre Derechos Humanos.

60.- Segundo Postulado: Las restricciones a los derechos, deben hacerse respetando el principio de legalidad.

61.- El principio de legalidad se relaciona directamente con el ejercicio de la democracia y el Estado de Derecho, por ende, para la Corte Interamericana de Derechos Humanos, el concepto de democracia es consubstancial con la protección de los derechos humanos en el continente.

62.- Algunos de los derechos, libertades y garantías consagrados en la Convención Americana sobre Derechos Humanos, son pasibles de suspensiones o restricciones, conforme al Capítulo IV del Pacto de San José de Costa Rica. Estas limitaciones sólo pueden llevarse adelante por un gobierno, a través de la sanción de una ley, en el sentido formal del término.

63.- Tercer Postulado: Para el acceso a la vía internacional del Sistema Interamericano de Derechos Humanos, debe procederse al agotamiento de los recursos internos.

64.- La exigencia de agotar los recursos internos, antes de llevar adelante un procedimiento internacional, es un requisito típico del Derecho Internacional general.

65.- En materia de protección internacional de los derechos humanos, éste requisito responde a la característica de subsidiariedad, propia de aquel ordenamiento jurídico.

66.- El no agotamiento de los recursos internos es una excepción que válidamente pueden interponer los Estados, en un proceso de derechos humanos en su contra. La Corte Interamericana de Derechos Humanos ha ido poniendo límites y condiciones a esta excepción, para que no se transforme en una herramienta de impunidad.

67.- Un Estado tiene la facultad de oponer dicha excepción en un proceso, es decir, aquel puede renunciar a dicha excepción, y ésta renuncia puede ser expresa o tácita, dándose este último caso cuando no ha sido opuesta en tiempo oportuno (principio de preclusión).

68.- La regla no es oponible si los recursos internos no existen, no son procedentes, no sirven para los fines que fueron creados, o cuando por algún motivo justificable el individuo se ha visto impedido de agotar las instancias domésticas. Es obligatorio para el Estado organizar el aparato estatal, de forma tal que el acceso a los recursos internos no se torne ilusorio.

69.- Si un Estado invoca el no agotamiento de los recursos internos, a él le corresponde probarlo en la instancia internacional.

70.- Cuarto Postulado: Los procedimientos del Sistema Interamericano de Derechos Humanos, deben llevarse adelante bajo el respeto al principio de seguridad jurídica. 
71.- La seguridad jurídica es un requisito indispensable en un procedimiento internacional de derechos humanos; puede ser traducida en la existencia de un sistema transparente de juzgamiento, con reglas claras, órganos imparciales, y las garantías propias de la defensa en juicio.

72.- La inobservancia de formalidades secundarias no puede traducirse en la impunidad para un Estado, en virtud de la seguridad jurídica, ya que ésta debe ser conjugada con el principio «pro homine», medular y propio del Derecho Internacional de los Derechos Humanos.

73.- Quinto Postulado: Los Estados deben respetar y aplicar el principio de buena fe.

74.- Los Estados, en sus relaciones, deben comportarse de buena fe, así como cumplir de buena fe sus obligaciones internacionales, en particular las establecidas en instrumentos jurídicos de derechos humanos.

75.- Los gobiernos deben proceder de buena fe, en todo proceso internacional que se lleve en su contra, por violación a los derechos y libertades fundamentales de la persona.

76.- Sexto Postulado: Los tribunales internacionales poseen amplia libertad para evaluar los medios de prueba, sin sujetarse a parámetros estrictos.

77.- Los medios probatorios en Derecho Internacional y en derecho interno son similares, pero los criterios de valoración de los mismos son menos formales en el primero.

78.- En materia de derechos humanos esta tendencia se acentúa, ya que no siempre los Estados se muestran dispuestos a colaborar en la resolución de la causa. Particularmente, en asuntos sobre desaparición forzada de personas, la prueba indiciaria asume un papel importante.

79.- Séptimo Postulado: El juez conoce el derecho: «iura novit curia».

80.- En un proceso internacional, y particularmente por violaciones a los derechos humanos, la no invocación de una regla por alguna de las partes no impide su aplicación y análisis por el Tribunal.

81.- Octavo Postulado: En materia de derechos humanos, rige el principio de continuidad del Estado.

82.- Aunque cambie un gobierno, esta circunstancia no exime la responsabilidad del Estado por violaciones a los derechos humanos, en virtud del principio de continuidad, es decir, los hechos ilícitos internacionales generan responsabilidad para el Estado más allá de los cambios de gobierno.

83.- Noveno Postulado: El daño producido por la violación de una norma de Derecho Internacional, engendra el derecho a una reparación adecuada.

84.- Dicha reparación encuentra su fundamento en el Derecho Internacional, y en materia de derechos humanos se aplica el concepto de «reparación integral», el cual consiste en el restablecimiento de la situación anterior y la reparación de las consecuencias que la infracción produjo, junto al pago de una indemnización como compensación por los daños patrimoniales y extrapatrimoniales, incluyendo el daño moral.

85.- En un caso por violaciones a los derechos humanos, los perjuicios materiales incluyen, los rubros conocidos en el derecho interno como «daño emergente» y «lucro cesante».

\section{V.- En cuanto a los Postulados emergentes de la jurisprudencia de la Corte Interamericana, tomados del Derecho Internacional de los Derechos Humanos}

86.- Décimo Postulado: Los tratados de derechos humanos tienen una naturaleza propia, disímil de los tratados comunes en el Derecho Internacional.

87.- Existe una diferencia básica entre un tratado de tipo tradicional y uno de derechos humanos, que deriva de la distinta naturaleza de uno y otro: el primero se refiere a derechos y acuerdos de Estados entre sí; el segundo también consiste en acuerdos entre Estados, pero no a derechos y obligaciones recíprocas de estos entre sí, sino que se regulan un mínimo de prerrogativas, que les corresponden a los individuos que residen en el territorio de los Estados partes en dicho convenio.

88.- El incumplimiento de un tratado de derechos humanos por un Estado parte, no le da derecho a otro Estado parte a incumplirlo también; es decir, en la materia no rige la llamada «regla de reciprocidad». 
89.- La Convención Americana sobre Derechos Humanos entra en vigencia para un Estado que ha formulado reservas a la misma, en el mismo momento del depósito del instrumento de ratificación o adhesión a la Convención.

90.- Décimo Primer Postulado: Las normas de derechos humanos deben interpretarse en el sentido más favorable a las presuntas víctimas, y la actuación de los órganos de protección de los derechos humanos, debe realizarse en la misma dirección.

91.- Si a una misma situación se pueden aplicar diferentes instrumentos de derechos humanos, debe prevalecer la norma que sea más favorable a la persona.

92.- La doctrina elaborada por la Corte Interamericana de Derechos Humanos ha mantenido, en general, ésta regla conocida como principio «pro homine».

93.- Los derechos contenidos en la Convención Americana sobre Derechos Humanos deben considerarse, por regla general, operativos. Si en el derecho interno no existen las condiciones para el goce de un derecho contemplado en el Pacto de San José, cualquier disposición que se tome dentro del Estado es válida para hacerlo operativo; en cambio, toda regla de la Convención que se refiera a la adopción de una norma para restringir o suspender derechos o garantías, sólo es posible adoptarla bajo la figura de una ley en el sentido formal.

94.- Las garantías imposibles de suspender conforme a la Convención Americana deben entenderse en un sentido amplio, y son todas aquellas que posea cada ordenamiento jurídico interno, necesarias para tutelar los derechos que no pueden ser objeto de restricciones.

95.- Un límite a la actuación de la competencia consultiva de la Corte Interamericana, está dado cuando existe la posibilidad que, del estudio o de la resolución de la cuestión, se puedan vulnerar los derechos fundamentales de las personas, ya que esto desnaturalizaría la función consultiva del Tribunal.

96.- El ejercicio de los derechos, libertades y garantías contenidos en la Convención Americana, también debe interpretarse desde aquella posibilidad que sea más favorable a la víctima.

97.- Décimo Segundo Postulado: Los instrumentos o medios procesales destinados a garantizar los derechos humanos, deben ser efectivos.

98.- Los Estados Partes deben organizar el aparato estatal, de forma tal que los mecanismos internos para garantizar los derechos contenidos en la Convención Americana sobre Derechos Humanos, funcionen correctamente y sean eficaces.

99.- La suspensión de cualquiera de esos mecanismos o garantías, puede considerarse, per se, una violación a los derechos y libertades establecidos en la Convención Americana sobre Derechos Humanos.

100.- Décimo Tercer Postulado: Las declaraciones marco de derechos humanos son jurídicamente obligatorias, cuando constituyen la interpretación de los derechos humanos, contenidos en los tratados constitutivos de las Organizaciones Internacionales.

101.- La Declaración Americana de los Derechos y Deberes del Hombre es de cumplimiento jurídico obligatorio. Dicha obligatoriedad jurídica deriva del hecho de ser la definición de aquellos derechos humanos esenciales, a que se refiere la Carta de la Organización de los Estados Americanos.

102.- La Declaración Americana de Derechos y Deberes del Hombre configura, en el sentido descrito, una fuente de obligaciones internacionales, que deben cumplir los Estados miembros de la Organización de los Estados Americanos.

103.- Décimo Cuarto Postulado: Los Estados deben aplicar y respetar, el principio de no discriminación.

104.- El principio de no discriminación es un axioma medular del Derecho Internacional de los Derechos Humanos, y está contenido en la base de todos los instrumentos internacionales de protección.

105.- La noción de igualdad se desprende directamente de la unidad de naturaleza del género humano, y es inseparable de la dignidad esencial de la persona, frente a la cual es incompatible toda situación que, por considerar superior a un determinado grupo, conduzca a tratarlo con privilegio; o que, a la inversa, por considerarlo inferior lo trate con hostilidad, o de cualquier forma lo discrimine 
del goce de derechos, que sí se reconocen a quiénes no se consideran incursos en tal situación de inferioridad. No es admisible crear diferencias de tratamiento entre seres humanos que no se correspondan con su única e idéntica naturaleza.

106.- Lo anterior no significa que la discriminación positiva no pueda ser aceptada. Ella es beneficiosa para un cumplimiento efectivo de los derechos humanos, cuando su establecimiento legal, o su aplicación por parte de órganos internacionales, suple desigualdades de hecho.

\section{VI.- En cuanto a los Postulados emergentes de la jurisprudencia de la Corte Interamericana, de creación pretoriana del Tribunal.}

107.- Los Postulados de creación pretoriana de la Corte Interamericana de Derechos Humanos, encuentran su fundamento en la búsqueda de respuestas a situaciones jurídicas complejas que llegaron ante el Tribunal.

108.- Décimo quinto Postulado: El ámbito de la función consultiva de la Corte Interamericana es el más amplio posible, dentro de los límites establecidos por la Convención Americana sobre Derechos Humanos.

109.- Las decisiones de la Corte Interamericana de Derechos Humanos sobre el alcance de su función consultiva, han sido resueltas en favor de su más amplia competencia.

110.- La Corte Interamericana de Derechos Humanos, para el cumplimiento de su función consultiva, puede interpretar cualquier tratado, en el que sea parte un Estado miembro de la Organización de los Estados Americanos.

111.- La Corte Interamericana puede también interpretar la Declaración Americana sobre Derechos y Deberes del Hombre, en cuanto ésta contiene la definición y alcance de los derechos fundamentales que se encuentran en la Carta de la Organización de los Estados Americanos.

112.- La Corte Interamericana, asimismo, puede interpretar el grado de compatibilidad entre la legislación interna de un Estado Miembro de la Organización de los Estados Americanos, y cualquiera de los instrumentos señalados en los dos acápites anteriores, a pedido del Estado en cuestión.

113.- La Corte Interamericana, finalmente, puede (también a pedido del Estado en cuestión) interpretar el grado de compatibilidad entre un proyecto de ley y aquellos instrumentos.

114.- Los límites al alcance de la función consultiva están dados porque en su tarea, la Corte Interamericana no puede desvincularse en ningún caso de los propósitos de la Convención Americana sobre Derechos Humanos. La otra posibilidad para que la Corte se abstenga de emitir una Opinión Consultiva es, si el hacerlo puede ir en desmedro de presuntas víctimas de derechos humanos, en un asunto que podría llegarle en materia contenciosa.

115.- La Corte es, por último, competente para decidir sobre si le corresponde o no emitir una opinión que le hayan solicitado, es decir, tiene competencia sobre su competencia.

116.- Décimo Sexto Postulado: Cuando se dan ciertos requisitos, la Comisión debería considerar especialmente, la posibilidad de llevar un caso contencioso ante la Corte Interamericana de Derechos Humanos.

117.- A la Corte sólo pueden llevarle casos la Comisión Interamericana de Derechos Humanos y los Estados; naturalmente, los Estados son poco propicios a remitir un asunto para el entendimiento del Tribunal en materia contenciosa. De ahí que, en ciertos casos y cuando se cumplen los requisitos formales, la Comisión Interamericana debería considerar especialmente, la posibilidad de elevar un asunto a conocimiento de la Corte.

118.- Enviar un caso a la Corte Interamericana de Derechos Humanos es una facultad de la Comisión Interamericana, lo cual no significa que esa facultad pueda ejercerse con arbitrariedad. La Comisión debe examinar primordialmente si dirige un asunto para su tratamiento ante la Corte Interamericana, cuando concurren ciertas circunstancias.

119.- Los criterios a tener en cuenta por la Comisión para tomar su decisión son: si el asunto plantea problemas legales controversiales no considerados todavía por la Corte, el grado de dificultad que ha acarreado la cuestión en la jurisdicción doméstica y en la propia Comisión 
Interamericana, y la importancia que la materia puede revestir para la protección de los derechos humanos en el continente americano.

120.- Décimo Séptimo Postulado: La desaparición forzada de personas, es una forma compleja de violación de varios derechos fundamentales.

121.- Las desapariciones forzadas constituyen un crimen de lesa humanidad.

122.- La práctica de las desapariciones forzadas conlleva una ruptura radical del Pacto de San José de Costa Rica, porque significa el abandono de valores que emanan de la dignidad humana y de los principios que dan fundamento al sistema interamericano.

123.- Las desapariciones forzadas de personas son una violación múltiple y continuada de varios derechos que, al estar contemplados en la Convención Americana, los Estados Partes se han comprometido a respetar, y a garantizar el ejercicio de los mismos.

124.- La práctica de la desaparición forzada conlleva una violación a los derechos a la libertad personal, a la integridad corporal, a no ser sometido a torturas, y a la vida.

125.- La doctrina elaborada por la Corte Interamericana de Derechos Humanos en relación a la desaparición forzada de personas, ha sido tomada posteriormente por la Asamblea General de la Organización de los Estados Americanos, para elaborar y adoptar la Convención Americana contra la Desaparición Forzada de Personas, en 1994.

126.- Décimo Octavo Postulado: Los hijos menores de víctimas de violaciones al derecho a la vida, deben tener asegurado especialmente su derecho a la educación.

127.- El derecho a la educación ya se encuentra contenido en numerosos instrumentos internacionales de derechos humanos. La Corte Interamericana ha ampliado el alcance de dicho derecho cuando concurren ciertos requisitos.

128.- Si una víctima de una violación al derecho a la vida, determinada como imputable al Estado por la Corte Interamericana de Derechos Humanos, tenía hijos en edad de estudiar, la vulnerabilidad engendrada del tipo de violación sufrida por aquella, merece especial atención.

129.- Una forma de atender esta situación de vulnerabilidad, es brindarle a dichos hijos la posibilidad de llevar adelante sus estudios, hasta una edad estimada de veinticinco años.

130.- Cuando concurren estos casos, la Corte dispone la creación de un fideicomiso, del cual los hijos retiran mensualmente los beneficios bancarios hasta los veinticinco años, momento a partir del cual perciben la parte alícuota de la indemnización que les corresponde.

131.- La Corte debe procurar efectivamente hacer cumplir este requisito; de allí que cuando por circunstancias especiales no estén dadas las condiciones para ello, el Tribunal puede disponer al efecto, obligaciones de hacer para el Estado. 


\section{BIBLIOGRAFIA Y DOCUMENTOS INTERNACIONALES UTILIZADOS}

\section{I.- BIBLIOGRAFIA}

ALBANESE, Susana: «Algunas comparaciones entre los sistemas regionales de promoción y protección de los derechos Humanos»; en: "El Derecho" 135:927, Buenos Aires, Argentina, 1992.

AL MIDANI, Mohamed Amín: «La Liga de Estados Arabes y los Derechos Humanos»; en: "La protección universal y regional de los derechos humanos"; Ed. Instituto de Relaciones Internacionales UNLP, La Plata, Argentina, 1995.

AL MIDANI, Mohamed Amín: «Charte Arabe des Droits de l'Homme» (traduction), en: "Revue Universelle des Droits de l'Homme" Vol. 7 N 4-6, Strasbourg, France, 1995.

AMNISTIA INTERNACIONAL: «Informe sobre la Tortura», Ed. Edai, Madrid, España, 1984.

AMNISTIA INTERNACIONAL: "Guía de la Carta Africana de los Derechos Humanos y de los Pueblos»; Ed. Edai, Madrid, España, 1991.

BARBERIS, Julio: «Los sujetos del Derecho Internacional», Ed. Técnos, Madrid, España, 1984.

BARBERIS, Julio: «Formación del Derecho Internacional»; Ed. Abaco de Rodolfo De Palma, Buenos Aires, Argentina, 1994.

BERGER, Vincent: «Jurisprudence de la Cour Européenne des Droits de L'Homme», 3 Edition, Ed. Sirey, Paris, France, 1991.

BIDART CAMPOS, Germán y HERRENDORF, Daniel: «Principios de derechos humanos y garantías»; Ed. Ediar; Buenos Aires, Argentina, 1991.

BLANC ALTEMIR, Antonio: «La violación de los derechos humanos fundamentales como crimen internacional»; Ed. Bosch S.A., Barcelona, España, 1990.

BOUTROS-GHALI, Boutros: «La Liga de Estados Arabes», en: "Las dimensiones internacionales de los derechos humanos" (K. Vasak editor), T III, Ed. SERBAL / UNESCO, París, Francia, 1984.

BUERGENTHAL, Thomas: «Las Convenciones Europea y Americana: algunas similitudes y diferencias»; en: "La Convención Americana sobre Derechos Humanos", Organización de los Estados Americanos, Washington, D.C. 1980.

BUERGENTHAL, Thomas: «Human Rigths, In a nut shell», Ed. West, Minessotta, United States, 1988.

BUERGENTHAL, Thomas; GROSSMAN, Claudio; y NIKKEN, Pedro: «Manual internacional de derechos humanos», IIDH, Ed. Jurídica Venezolana, Caracas, Venezuela 1990.

BUERGENTHAL, Thomas; NORRIS, Robert y SHELTON, Dinah: «La protección de los derechos humanos en las Américas». Instituto Interamericano de Derechos Humanos, Ed. Civitas, Madrid, España 1990.

BUERGENTHAL, Thomas, y SHELTON, Dinah: «Protecting Human Rights in the Americas» Cases and Materials, Ed. International Institute of Human Rights, Strasbourg, N.P. Engel, Publisher, United States, 1995.

CANÇADO TRINDADE, Antônio: «O esgotamento de recursos internos no Direito Internacional» Ed. Universidade de Brasilia, Brasil 1984.

CANÇADO TRINDADE, Antônio: «Environment and Development: formulation and implementation of the Right to Development as a Human Right»; en: "Derechos Humanos, Desarrollo Sustentable y Medio Ambiente"; Ed. IIDH, San José / Brasilia, Brasil; 1992.

CANÇADO TRINDADE, Antônio: «El Sistema Interamericano de protección a los Derechos Humanos»; en: "Recueil des Cours 1993, Collection of Lectures, Texts and Summaries"; Ed. Institut International de Droits De l'Homme, Strasbourg, France, 1993. 
CANÇADO TRINDADE, Antônio: «Memória da Confêrencia Mundial de Direitos Humanos»; en: "Boletim de Sociedade Brasileira de Direito Internacional"; Año XLVI Junho/Dezembro 1993 N 87/90; Brasilia, Brasil, 1993.

CANÇADO TRINDADE, Antônio: «Democracia y derechos humanos: el régimen emergente de la promoción internacional de la democracia y del Estado de Derecho»; en: "La Corte y el Sistema Interamericanos de Derechos Humanos", Ed. IIDH, San José de Costa Rica, 1994.

CANÇADO TRINDADE, Antônio: «Balance de los resultados de la Conferencia Mundial de Derechos Humanos», en: "Estudios básicos de Derechos Humanos III", Ed. IIDH, San José de Costa Rica, 1995.

CANÇADO TRINDADE, Antônio: «Alalyses of the legal implications for states that intend to ratify both the European Convention on Human Rights and its Protocols and the Convention on Human Rights of the Commonwealth of Independent States»; en: "SG/INF (95) 17" Council of Europe; Strasbourg, France, 1995.

CANÇADO TRINDADE, Antônio: «El sistema interamericano de protección de los derechos humanos (1948 - 1995): evolución, estado actual y perspectivas»; en: "Derecho Internacional y Derechos Humanos"; libro conmemorativo de la XXIV Sesión Exterior de la Academia de Derecho Internacional de La Haya; Ed. IIDH; San José de Costa Rica, 1996.

CARRILLO SALCEDO, Juan A.: «Curso de Derecho Internacional Público», Ed. Técnos, Madrid, España, 1991.

CARRILLO SALCEDO, Juan A.: «E1 Derecho Internacional en perspectiva histórica»; Ed. Técnos, Madrid, España, 1991.

CARRILLO SALCEDO, Juan A.: «Algunas reflexiones sobre el valor jurídico de la Declaración Universal de Derechos Humanos», Ed. Técnos, Madrid, España, 1993.

CARRILlO SALCEDO, Juan A.: «Soberanía de los Estados y Derechos Humanos en Derecho Internacional Contemporáneo»; Ed. Técnos, Madrid, España, 1995.

CARRILLO SALCEDO, Juan A. y SALADO OSUNA, Ana: «El mecanismo de garantía instituido en la Convención Americana sobre Derechos Humanos», en: "Derecho Internacional Público II"; Curso 1995/6, Ed. Facultad de Derecho, Universidad de Sevilla, España, 1996.

CASADO RAIGON, Rafael: «La responsabilidad internacional resultante de la comisión de un crimen internacional»; en: "Derecho y Opinión", Revista del Departamento de Disciplinas Histórico Jurídicas y Económico Sociales, N 0, Córdoba, España, 1992.

CASTRO-RIAL GARRONE, Fanny: «La Carta Africana de Derechos Humanos y de los pueblos», en: "Revista Española de Derecho Internacional", Vol XXXVI, N 2 Madrid, España, 1984.

CASTRO-RIAL GARRONE, Fanny: «Los derechos humanos y la no intervención en los asuntos internos de los Estados» en: "Cursos de Derecho Internacional de Vitoria-Gasteiz", Universidad del País Vasco; Vitoria, España, 1990.

CASTRO-RIAL GARRONE, Fanny: «El sistema europeo de derechos humanos»; en: "La protección universal y regional de los derechos humanos"; Ed. Instituto de Relaciones Internacionales UNLP, La Plata, Argentina, 1995.

COLLIARD, Claude A.: «Instituciones de Relaciones Internacionales»; Ed. Fondo de Cultura Económica, Madrid, España, 1978.

CHUECA SANCHO, Angel: Las reservas a los Tratados de Derechos humanos"; en: "Documentación Jurídica" T XIX N 74, págs. 195 a 357; abril - junio de 1992. Ed. Ministerio de Justicia, Madrid, 1992.

DEGNI - SEGUI, Rene: «La Charte africane des droits de l' Homme et des Peuples»; en: "Recueil des Cours 1993, Collection of Lectures, Texts and Summaries"; Ed. Institut International de Droits de l' Homme, Strasbourg, France, 1993.

DIAZ CISNEROS, César: «Derecho Internacional Público» (Segunda Edición actualizada); Tomo I, Ed. TEA, Buenos Aires, Argentina, 1966.

DIEZ DE VELASCO, Manuel: «Instituciones de Derecho Internacional Público», Tomo I, 9na edición, Ed. Técnos, Madrid, España, 1993. 
DRZEMCZEWSKI, Andrew: «Advisory Jurisdiction of the European Human rights Court: A Procedure Worth Retaining?»; en "El mundo moderno de los derechos humanos. Ensayos en honor de Thomas Buergenthal"; Ed. Instituto Interamericano de Derechos Humanos, San José de Costa Rica, 1996.

DUNSHEE DE ABRANCHES, C. A.: «La Corte Interamericana de Derechos Humanos», en: "La Convención Americana sobre Derechos Humanos", Ed. Comisión Interamericana de Derechos Humanos, Washington, Estados Unidos, 1980.

DUPUY, Pierre-Marie: «Droit International Public»; IIéme Edition, Ed. Dalloz, Paris, France, 1993.

ESCOBAR HERNANDEZ, Concepción: «Algunas consideraciones críticas sobre el funcionamiento de los mecanismos extraconvencionales de control establecidos por la Comisión de Derechos Humanos de las Naciones Unidas» en: "Hacia una justicia universal", Ed. Comisión Internacional de Juristas, Ginebra, Suiza, 1993.

ESCOBAR HERNANDEZ, Concepción: «Las Organizaciones Internacionales en América», en Diez de Velasco, Manuel: "Las Organizaciones Internacionales" (novena edición), Cap. XXX, Ed. Técnos, Madrid, España, 1995.

ESPINAL ARIAS, Rigoberto: «Competencia y funciones de la Corte Interamericana de Derechos Humanos», en: "La Corte y el Sistema Interamericanos de Derechos Humanos", Ed. IIDH, San José de Costa Rica, 1994.

FIX ZAMUDIO, Héctor: «La protección judicial de los derechos humanos en Latinoamérica y en el Sistema Interamericano»; en: "Revista N 8". Ed. Instituto Interamericano de Derechos Humanos, San José de Costa Rica, 1988.

FLAUSS, J. F.: «Le droit de recours individuel devan la Cour Européene des Droits de 1' Homme», en: "Annuaire Francais de Droit Intenational" XXXVI, París, France, 1990.

GARCIA AMADOR, F.V.: «El Derecho Internacional del desarrollo. Una nueva dimensión del Derecho Internacional económico»; Ed. Cívitas, Madrid, España, 1987.

GARCIA GHIRELLI, José: «Repertorio de jurisprudencia de la Corte Internacional de Justicia»; Ed. Zavalía, Buenos Aires, Argentina, 1973.

GROS ESPIELL, Héctor: «El derecho a la libre determinación de los Pueblos y los Derechos Humanos»; en: "Estudios sobre Derechos Humanos Tomo I", Ed. Jurídica Venezolana, Caracas, Venezuela, 1985.

GROS ESPIELL, Héctor: «No discriminación y libre determinación como normas imperativas de Derecho Internacional, con especial referencia a los efectos de su denegación sobre la legitimidad de los Estados que violan o desconocen esas normas imperativas»; en: "Estudios sobre Derechos Humanos I"; Ed. Jurídica Venezolana, Caracas Venezuela, 1985.

GROS ESPIELL, Héctor: «El procedimiento contencioso ante la Corte Interamericana de Derechos Humanos», en: "Estudios básicos de derechos humanos II", Ed. Civitas, Instituto Interamericano de Derechos Humanos, San José de Costa Rica, 1988.

GROS ESPIELL, Héctor: «La Convención Americana y la Convención Europea de Derechos Humanos: análisis comparativo»; Ed. Jurídica de Chile; Santiago, Chile, 1991.

GROSSMANN, Claudio: «Reflexiones sobre el sistema interamericano de protección y promoción de los derechos humanos» en "La Corte y el Sistema Interamericanos de Derechos Humanos", San José de Costa Rica, 1994.

HITTERS, Juan C.: «La Corte Interamericana y la condena al gobierno de Honduras, aspectos procesales»; en: "Revista Uruguaya de Derecho Procesal" N 3, Montevideo, Uruguay, 1988.

HITTERS, Juan C.: «Derecho Internacional de los Derechos Humanos», Tomos I y II; Ed. Ediar, Buenos Aires, Argentina, 1991.

JIMENA QUESADA, Luis: «Le systéme interaméricain de protection des droits de l' homme», en: "Recueil des Cours 1995: Collection of Lectures, Textes et Sommaires"; Ed. Institut International des Droits De l'Homme, Strasbourg, France, 1995.

JIMENA QUESADA, Luis and SALVIOLI, Fabián: «The individual, Human Rights and International Instruments: Focus on the Council of Europe». en The ELSA Law Review, N 2, 1994. Ed. DJOF Publishing; Copenhagen, Denmark, 1994. 
JIMENEZ DE ARECHAGA, Eduardo: «El Derecho Internacional Contemporáneo», Ed. Técnos, Madrid, España, 1980.

JUSTE RUIZ, José: «Derecho Internacional Público, Textos Básicos», Valencia, España, 1991.

KELSEN, Hans: «Principios de Derecho Internacional Público»; Ed. El Ateneo, Buenos Aires, Argentina, 1965.

KLAINER, Rosa; LOPEZ, Daniel y SALVIOLI, Fabián: «El Derecho a la educación». Curso Taller de Educación a Distancia para Docentes: Módulo 2; Ed. Movimiento Ecuménico por los Derechos Humanos, Buenos Aires, Argentina, 1992.

KLAINER, Rosa; LOPEZ, Daniel y SALVIOLI, Fabián: «El Derecho a la Identidad». Curso Taller de Educación a Distancia para Docentes: Módulo 3. Ed. Movimiento Ecuménico por los Derechos Humanos; Buenos Aires, Argentina, 1993.

LESCURE, Karine: «Le Tribunal Pénal International pour L'ex Yougouslavie»; Ed. Cedin - Paris I, France, 1994.

LINDGREN ALVES, J.A.: «Población, desarrollo y derechos: la Conferencia de El Cairo de 1994»; en: "Estudios Básicos de Derechos Humanos III"; Ed. Instituto Interamericano de Derechos Humanos; San José de Costa Rica, 1995.

MARIE, Jean Bernard: «La pratique de la Comission des Droits de 1' Homme de 1' O.N.U. en matière de violations des droits de l' homme»; en: "Revue Belge de Droit International", Vol. X, Bruxelles, Belgique, 1980.

MARIE, Jean Bernard: «Instruments internationaux relatifs aux droits de l'Homme. Classification et état des ratification au 1er Janvier 1996; en: "Human Rights Law Journal" Vol. 17 N 1-2; N.P. Engel, Publisher, Strasbourg, France 1996.

MARIÑO MENENDEZ, Fernando: «Derecho Internacional Público (parte general)»; Ed. Trotta, Madrid, España, 1993.

MARKS, Stephen: «La Comission Permanente Arabe des Droits de l' Homme», en: "Revue Universelle des Droits de 1' Homme" Vol. 3 N 1, Strasbourg, France, 1970.

MASKIN, Héctor: «El Sistema Europeo de Derechos Humanos»; Ed. Eudeba, Buenos Aires, Argentina, 1987.

MATHIEH, Jean Luc: «La défense internationale des Droits de l' Homme», en: "¿Que sais je?" N 2733; Ed. Presses Universitaires de France, Paris, France, 1993.

MEDINA, Cecilia: «El sistema interamericano de promoción y protección de los derechos humanos», en: "Derecho Internacional de los Derechos Humanos", manual de enseñanza; Ed. Instituto Holandés de Derechos Humanos, Amsterdam, Holanda, 1990.

MENDEZ, Juan: «La participación de la víctima ante la Corte Interamericana de Derechos Humanos», en "La Corte y el Sistema Interamericanos de Derechos Humanos", Ed. Instituto Interamericano de Derechos Humanos, San José de Costa Rica, 1994.

MENDEZ, Juan: «Criterios para enviar casos a la Corte, plazos para referir un caso a la Corte (Artículos 50 y 51 de la Convención Americana de Derechos Humanos) y solicitud de reconsideración y de interrupción del plazo»; ponencia presentada al Seminario "El Sistema Interamericano de Promoción y Protección de los Derechos Humanos", Comisión Interamericana de Derechos Humanos, Washington, Estados Unidos, 1996.

MIGNONE, Emilio: «Los derechos económicos, sociales y culturales en las constituciones políticas de los países del cono sur de América»; en: "Estudios Básicos de Derechos Humanos V"; Ed. Instituto Interamericano de Derechos Humanos; San José de Costa Rica, 1996.

NIETO NAVIA, Rafael: «Introducción al sistema interamericano de protección a los derechos humanos»; Ed. Instituto Interamericano de Derechos Humanos, Temis, Bogotá, Colombia, 1993.

NIETO NAVIA, Rafael: «La Corte Interamericana de Derechos Humanos», en: «Estudios Básicos sobre Derechos Humanos I»; Ed. Instituto Interamericano de Derechos Humanos, San José de Costa Rica, 1994.

NIETO NAVIA, Rafael: (editor) «La Corte y el Sistema Interamericanos de Derechos Humanos», Ed. Instituto Interamericano de Derechos Humanos, San José de Costa Rica, 1994. 
NIKKEN, Pedro: «La protección Internacional de los derechos humanos: su desarrollo progresivo»; Ed. Instituto Interamericano de Derechos Humanos / Cívitas, Madrid, España, 1987.

O' DONNELL, Daniel: «Protección internacional de los derechos humanos», Ed. Comisión Andina de Juristas, Lima, Perú, 1988.

ORDOÑEZ, Jaime y VAZQUEZ, Enrique: «Derechos Económicos y Desarrollo en América Latina». Ed. Instituto Interamericano de Derechos Humanos, San José, Costa Rica, 1991.

PASQUALUCCI, Jo M.: «Medidas provisionales en la Corte Interamericana de Derechos Humanos: una comparación con la Corte Internacional de Justicia y la Corte Europea de Derechos Humanos», en: "Revista N 19" del Instituto Interamericano de Derechos Humanos, Ed. IIDH, San José, Costa Rica, 1994.

PASTOR RIDRUEJO, José: «La determinación del contenido del ius cogens», Ponencia del XI Congreso del Instituto Luso Americano de Derecho Internacional, Madrid, España, 1972.

PASTOR RIDRUEJO, José: «Curso de Derecho Internacional Público y Organizaciones Internacionales», 4ta Edición,, Ed. Técnos, Madrid, España, 1992.

PINTO, Mónica: «Encuadramiento jurídico internacional de la desaparición forzada de personas», en "La Desaparición, crimen contra la humanidad"; Ed: APDH, Buenos Aires, Argentina, 1987.

PINTO, Mónica: «La denuncia ante la Comisión Interamericana de Derechos Humanos»; Ed. Del Puerto, Buenos Aires, Argentina, 1993.

PIZA, Rodolfo: «La Coordinación de los Mecanismos de la Convención Americana sobre Derechos Humanos con respecto a los establecidos por el sistema de las Naciones Unidas para la promoción y protección de los derechos humanos»; en: "La Convención Americana Sobre Derechos Humanos", Ed. OEA Washington DC, Estados Unidos, 1980.

PODESTA COSTA, Luis y RUDA, José María: «Manual de Derecho Internacional Público», Tomo I. Ed. TEA, Buenos Aires, Argentina, 1985.

PUIG, Juan C.: «Derecho de la Comunidad Internacional»; Ed. Depalma, Buenos Aires, Argentina, 1986.

QUINTANA, Juan José: «Los procedimientos incidentales ante la Corte Interamericana de Derechos Humanos», en: "Revista N 21", Ed. Instituto Interamericano de Derechos Humanos, San José de Costa Rica, 1995.

RANJEVA, Raymond y CADOUX, Charles: «Droit International Public»; Ed. Edicef/Aupelf, Universités Francophones, Paris, France, 1992.

RISHMAWI, R.: «Human Rights developments within the League of Arab States and in Asia», en: "Recueil des Cours 1995: Collection of Lectures, Textes et Sommaires" XXVII Session d'Enseignement, Ed: Institut International des Droits de l' Homme, Strasbourg, France, 1996.

RODRIGUEZ RESCIA, Víctor: «Eficacia jurídica de la jurisprudencia de la Corte Interamericana de Derechos Humanos», en: "La Corte y el Sistema Interamericanos de Derechos Humanos", (Nieto Navia Editor), IIDH, San José de Costa Rica, 1994.

SALVIOLI, Fabián: «La protección de los derechos humanos en el sistema interamericano: sus logros y dificultades»; en: "Relaciones Internacionales N 4"; Ed. Instituto de Relaciones Internacionales UNLP, La Plata, Argentina, 1993.

SALVIOLI, Fabián: «La Conferencia de Viena: el Debate sobre Derechos Humanos en las Relaciones Internacionales Contemporáneas» en: "Relaciones Internacionales". Serie Documentos, N 4; Ed. Instituto de Relaciones Internacionales, UNLP, La Plata, Argentina, 1993.

SALVIOLI, Fabián: «La tutela de los derechos en el sistema interamericano»; en "Revista Tribuno", Publicación del Colegio de Abogados de la Primera Circunscripción de la Provincia de Córdoba; año 2 N 6, Córdoba, Argentina, 1995.

SALVIOLI, Fabián: «Algunas reflexiones sobre la indemnización en las sentencias de la Corte Interamericana de Derechos Humanos», en "Estudios Básicos de Derechos Humanos III", Ed. Instituto Interamericano de Derechos Humanos, San José de Costa Rica, 1995. 
SALVIOLI, Fabián: «La responsabilidad internacional estatal e individual mirada desde la Corte Interamericana de Derechos Humanos (a propósito de la Opinión Consultiva N 14)», en: "Relaciones Internacionales", año 5, N 8; Ed. Instituto de Relaciones Internacionales, La Plata, Argentina, 1995.

SALVIOLI, Fabián: «El sistema interamericano de protección de los derechos humanos», en: "Recueil des Cours 1995: Collection of Lectures, Textes et Sommaires" XXVIème Session d'Enseignement; Ed. Institut International des Droits de l'Homme, Strasbourg, France, 1995.

SALVIOLI, Fabián: «Los desafíos del sistema interamericano de protección de los derechos humanos»; en: "Estudios Básicos de Derechos Humanos V"; Ed. Instituto Interamericano de Derechos Humanos, San José de Costa Rica, 1996.

SALVIOLI, Fabián: «El sistema interamericano de protección de los derechos humanos», en: "Recueil des Cours 1995: Collection of Lectures, Textes et Sommaires" ; XXVII Session d'Enseignement, Ed: Institut International des Droits de 1' Homme; Strasbourg, France, 1996.

SALVIOLI, Fabián: «La justicia como garante de la dignidad humana: las sentencias de la Corte Interamericana de Derechos Humanos contra Estados»; en: "Amnistía Internacional, revista bimestral para los países de habla hispana", $N$ 20, agosto/setiembre 1996; Ed. Edai, Madrid, España, 1996.

SALVIOLI, Fabián: «La mujer en el Derecho Internacional Público: un viaje de medio siglo desde San Francisco a Pekín»; en: "A un año de Beijing" Ed. Instituto de Relaciones Internacionales UNLP, La Plata, Argentina, 1996.

SALVIOLI, Fabián: «Relaciones Internacionales, Derechos Humanos y Educación para la Paz»; en: "Human Rigths: The Promise for the XXIst Century / Direitos Humanos: A promessa do século XXI"; Ed. Universidade Portucalense, Oporto, Portugal, 1997.

SALVIOLI, Fabián: «La Conferencia de Viena de las Naciones Unidas. Esperanzas y frustraciones en materia de derechos humanos»; en: "Human Rigths: The Promise for the XXIst Century / Direitos Humanos: A promessa do século XXI"; Ed. Universidade Portucalense, Oporto, Portugal, 1997.

SALVIOLI, Fabián y JIMENA QUESADA, Luis: «El individuo y los derechos humanos. Especial referencia al marco regional del Convenio Europeo»; en: "Relaciones Internacionales", año 4 N 6; Ed. Instituto de Relaciones Internacionales (UNLP), La Plata, Argentina, 1994.

SAN JOSE GIL, Amparo: «La protección de los derechos humanos en el ámbito internacional», Ed. Tirant lo Blanch, Valencia, España, 1992.

SANCHEZ LEGIDO, Angel: «La reforma del mecanismo de control del Convenio Europeo de Derechos Humanos»; Ed. Colex, Madrid, España, 1995.

SANTOSCOY-NORO, Berta: «Le systéme interaméricain de protection des droits de 1' Homme», en: "Recueil des Cours: Collection of Lectures, Textes et Sommaires"; Institut International des Droits de 1' Homme, Strasbourg, France, 1996.

SHIRER, William L.: «The Rise and Fall of the Third Reich»; Ed. Simon and Schuster, 1960.

SORENSEN, Max: «Manual de Derecho Internacional Público»; cuarta reimpresión al español, Editorial Fondo de Cultura Económica. México D.F., México, 1992.

SUDRE, Frédéric: «Droit International et Europeén des droits de l'homme», Ed. Presse Universitaire de France, París, 1989.

TRAVIESO, Juan A.: «Derechos humanos y Derecho Internacional»; Ed. Heliasta, Buenos Aires, Argentina, 1990.

TRAVIESO, Juan A: «La Corte Interamericana de Derechos Humanos. Opiniones Consultivas y Fallos»; Ed. Abeledo Perrot, Buenos Aires, Argentina, 1996.

URIBE VARGAS, Diego: «El derecho a la paz», en: "Derecho Internacional y Derechos Humanos", Editores Daniel Bardonnet y Antonio Cançado Trindade; Ed. Academia de Derecho Internacional de La Haya e Instituto Interamericano de Derechos Humanos, San José, Costa Rica / La Haya, Holanda, 1996.

VASAK, Karol: «Las dimensiones internacionales de los derechos humanos»; Tomos I, II y III; Ed. Serbal / UNESCO; París, Francia, 1984. 
VENTURA, Manuel y ZOVATTO, Daniel: «La función consultiva de la Corte Interamericana de Derechos Humanos»; IIDH Ed. Civitas; San José de Costa Rica, 1989.

VILLAGRAN KRAMER, F.: «Los derechos humanos y el principio de no intervención»; en: "Revista N 13"; Ed. Instituto Interamericano de Derechos Humanos, San José de Costa Rica, 1991.

VILLAN DURAN, Carlos: «Curso de Derecho Internacional de los Derechos Humanos»; Ed. Institut International des Droits de l' Homme, Strasbourg, France, 1995.

ZAVALIA, Víctor: «Recopilación de instrumentos internacionales», Ed. Zavalía, Buenos Aires, Argentina, 1984.

\section{II.- DOCUMENTOS, REVISTAS, ANUARIOS Y ESTUDIOS ESPECIALIZADOS}

Conseil de l'Europe: «Droits de l'Homme en Droit International», pág. 361, Ed. Conseil de l'Europe, Bruxelles, Belgique, 1992.

Corte Interamericana de Derechos Humanos: «Otros tratados: objeto de la función consultiva de la Corte». Opinión Consultiva OC-1/82 del 24 de setiembre de 1982. Serie A N 1. Secretaría de la Corte, San José de Costa Rica, 1982.

Corte Interamericana de Derechos Humanos: «El efecto de las reservas sobre la entrada en vigencia de la Convención Americana de Derechos humanos (arts. 74 y 75)». Opinión Consultiva OC2/82 del 24 de setiembre de 1982. Serie A N 2. Secretaría de la Corte, San José de Costa Rica, 1982.

Corte Interamericana de Derechos Humanos: «Restricciones a la pena de muerte (arts. 4.2 y 4.4, Convención Americana sobre Derechos Humanos)». Opinión Consultiva OC-3/83 del 8 de setiembre de 1983. Serie A N 3. Secretaría de la Corte Interamericana, San José de Costa Rica, 1983.

Corte Interamericana de Derechos Humanos: «Propuesta de modificación a la constitución política de Costa Rica relacionada con la naturalización». Opinión Consultiva OC-4/84 del 19 de enero de 1984. Serie A N 4. Secretaría de la Corte, San José de Costa Rica, 1984.

Corte Interamericana de Derechos Humanos: «La Colegiación Obligatoria de Periodistas (arts. 13 y 29 Convención Americana sobre Derechos Humanos)». Opinión Consultiva OC-5/85 del 13 de noviembre de 1985. Serie A N 5. Secretaría de la Corte; San José de Costa Rica, 1985.

Corte Interamericana de Derechos Humanos: «La expresión Leyes en el artículo 30 de la Convención Americana sobre Derechos Humanos». Opinión Consultiva OC-6/86 del 9 de mayo de 1986. Serie A N 6. Secretaría de la Corte, San José de Costa Rica, 1986.

Corte Interamericana de Derechos Humanos: «Exigibilidad del derecho de rectificación o respuesta (Arts. 14.1, 1.1 y 2, Convención Americana sobre Derechos Humanos)». Opinión Consultiva OC-7/86 del 29 de agosto de 1986. Serie A N 7. Secretaría de la Corte, San José de Costa Rica, 1986.

Corte Interamericana de Derechos Humanos: «El Hábeas Corpus bajo suspensión de garantías (Arts. 27.2, 25.1 y 7.6, Convención Americana sobre Derechos Humanos)». Opinión Consultiva OC-8/87 del 30 de enero de 1987. Serie A N 8. Secretaría de la Corte, San José de Costa Rica, 1987.

Corte Interamericana de Derechos Humanos: «Garantías judiciales en estado de emergencia (arts. 27.2, 25 y 8, Convención Americana sobre Derechos Humanos)». Opinión Consultiva OC9/87 del 6 de octubre de 1987. Serie A N 9. Secretaría de la Corte, San José de Costa Rica, 1987.

Corte Interamericana de Derechos Humanos: «Interpretación de la Declaración de los Derechos y Deberes del Hombre en el marco del artículo 64 de la Convención Americana sobre Derechos Humanos». Opinión Consultiva OC-10/89 del 14 de julio de 1989. Serie A N 10. Secretaría de la Corte, San José de Costa Rica, 1989.

Corte Interamericana de Derechos Humanos: «Excepciones al agotamiento de los recursos internos (Art. 46.1, 46.2.a y 46.2.b Convención Americana sobre Derechos Humanos)». Opinión 
Consultiva OC11/90 del 10 de agosto de 1990. Serie A N 11. Secretaría de la Corte, San José de Costa Rica, 1990.

Corte Interamericana de Derechos Humanos: «Compatibilidad de un proyecto de ley con el artículo 8.2.h de la Convención Americana sobre Derechos Humanos». Opinión Consultiva OC-12/91 del 6 de diciembre de 1991. Serie A N 12. Secretaría de la Corte, San José de Costa Rica, 1991.

Corte Interamericana de Derechos Humanos: «Ciertas atribuciones de la Comisión Interamericana de Derechos Humanos (artículos 41, 42, 46, 47, 50 y 51 de la Convención Americana sobre Derechos Humanos)». Opinión Consultiva OC-13/93 del 16 de julio de 1993. Serie A N 13. Secretaría de la Corte, San José de Costa Rica, 1993.

Corte Interamericana de Derechos Humanos: «Responsabilidad internacional por expedición y aplicación de leyes violatorias de la Convención Americana sobre Derechos Humanos (arts. 1 y 2 de la Convención Americana sobre Derechos Humanos)». Opinión Consultiva OC-14/94 del 9 de diciembre de 1994. Serie A N 14. Secretaría de la Corte, San José de Costa Rica, 1994.

Corte Interamericana de Derechos Humanos: «Asunto Viviana Gallardo y otras», decisión del 13 de noviembre de 1981, N G 101/81, Serie A.

Corte Interamericana de Derechos Humanos: «Caso Velásquez Rodríguez». Excepciones Preliminares. Resoluciones y Sentencias; Serie C, N 1. Sentencia del 26 de junio de 1987. Secretaría de la Corte, San José de Costa Rica, 1988.

Corte Interamericana de Derechos Humanos: «Caso Velásquez Rodríguez». Resoluciones y Sentencias; Serie C, N 4. Sentencia del 29 de julio de 1988. Secretaría de la Corte, San José de Costa Rica, 1988.

Corte Interamericana de Derechos Humanos: «Caso Velásquez Rodríguez». Indemnización compensatoria (Art. 63.1 Convención Americana sobre Derechos Humanos). Resoluciones y Sentencias; Serie C, N 7. Sentencia del 21 de julio de 1989. Ed. Secretaría de la Corte, San José de Costa Rica, 1990.

Corte Interamericana de Derechos Humanos: «Caso Godínez Cruz». Excepciones preliminares. Serie C, N 3. Sentencia del 26 de junio de 1987. Secretaría de la Corte, San José de Costa Rica, 1988.

Corte Interamericana de Derechos Humanos: «Caso Godínez Cruz». Serie C, resoluciones y Sentencias; N 5. Sentencia del 21 de julio de 1989; Ed. Secretaría de la Corte, San José de Costa Rica, 1989.

Corte Interamericana de Derechos Humanos: «Caso Godínez Cruz: indemnización compensatoria (Art. 63.1 Convención Americana sobre Derechos Humanos)». Serie C, resoluciones y Sentencias; N 8. Sentencia del 21 de julio de 1989. Ed. Secretaría de la Corte, San José de Costa Rica, 1990.

Corte Interamericana de Derechos Humanos: «Caso Fairén Garbi y Solís Corrales»; Serie C, resoluciones y Sentencias; N 6. Sentencia del 15 de marzo de 1989; Ed. Secretaría de la Corte, San José de Costa Rica, 1989.

Corte Interamericana de Derechos Humanos: «Caso Neira Alegría y Otros». Excepciones preliminares. Serie C, N 13. Sentencia del 11 de diciembre de 1991. Secretaría de la Corte, San José de Costa Rica, 1991.

Corte Interamericana de Derechos Humanos: «Caso Neira Alegría y Otros»: sentencia del 19 de enero de 1995; en: Corte Interamericana de Derechos Humanos, Informe Anual 1995, págs. 41 a 62. Ed. Secretaría General de la Organización de los Estados Americanos, Washington D.C., Estados Unidos, 1996.

Corte Interamericana de Derechos Humanos: «Caso Neira Alegría y otros». Sentencia sobre reparaciones del 19 de setiembre de 1996; en: Corte Interamericana de Derechos Humanos CDH - CP6/96, pág. 3. Ed. Secretaría de la Corte, San José de Costa Rica; 8 de octubre de 1996. 
Corte Interamericana de Derechos Humanos: «Caso Cayara; Excepciones Preliminares». Serie C, resoluciones y Sentencias; N 14. Sentencia del 3 de febrero de 1993; Ed. Secretaría de la Corte, San José de Costa Rica, 1994.

Corte Interamericana de Derechos Humanos: «Caso Gangaram Panday». Excepciones preliminares. Serie C, N 12. Sentencia del 4 de diciembre de 1991. Secretaría de la Corte, San José de Costa Rica, 1991.

Corte Interamericana de Derechos Humanos: «Caso Gangaram Panday». Sentencia del 21 de enero de 1994; en: Corte Interamericana de Derechos Humanos, Informe Anual 1994; págs. 21 a 42. Ed. Secretaría General de la Organización de los Estados Americanos, Washington D.C., Estados Unidos, 1995.

Corte Interamericana de Derechos Humanos: «Caso Aloeboetoe y otros»; Serie C, resoluciones y Sentencias; N 11. Sentencia del 4 de diciembre de 1991; Ed. Secretaría de la Corte, San José de Costa Rica, 1994.

Corte Interamericana de Derechos Humanos: «Caso Aloeboetoe y otros, Reparaciones (Art. 63.1 Convención Americana sobre Derechos Humanos)». Serie C, resoluciones y Sentencias; N 15. Sentencia de 10 de setiembre de 1993; Ed. Secretaría de la Corte, San José de Costa Rica, 1994.

Corte Interamericana de Derechos Humanos: «Caso Caballero Delgado y Santana». Excepciones preliminares. Serie C, N 17. Sentencia del 21 de enero de 1994. Secretaría de la Corte, San José de Costa Rica, 1994.

Corte Interamericana de Derechos Humanos: «Caso Caballero Delgado y Santana». Sentencia del 8 de diciembre de 1995; en: Corte Interamericana de Derechos Humanos, Informe Anual 1995; págs. 135 a 163. Ed. Secretaría General de la Organización de los Estados Americanos, Washington D.C., Estados Unidos, 1996.

Corte Interamericana de Derechos Humanos: «Caso Maqueda». Sentencia del 18 de enero de 1995; en: Corte Interamericana de Derechos Humanos, Informe Anual 1995; págs. 31 a 37. Ed. Secretaría General de la Organización de los Estados Americanos, Washington D.C., Estados Unidos, 1996.

Corte Interamericana de Derechos Humanos: «Caso El Amparo». Sentencia del 18 de enero de 1995; en: Corte Interamericana de Derechos Humanos, Informe Anual 1995; págs. 23 a 29.

Ed. Secretaría General de la Organización de los Estados Americanos, Washington D.C., Estados Unidos, 1996.

Corte Interamericana de Derechos Humanos: «Caso Neira Alegría y otros». Sentencia del 19 de enero de 1995; en: Corte Interamericana de Derechos Humanos, Informe Anual 1995; págs. 41 a 62. Ed. Secretaría General de la Organización de los Estados Americanos, Washington D.C., Estados Unidos, 1996.

Corte Interamericana de Derechos Humanos: «Caso El Amparo». Sentencia sobre reparaciones del 14 de setiembre de 1996; en: Corte Interamericana de Derechos Humanos CDH - CP6/96, pág. 2. Ed. Secretaría de la Corte, San José de Costa Rica; 8 de octubre de 1996.

Corte Interamericana de Derechos Humanos: «Caso Garrido y Baigorria». Sentencia del 2 de febrero de 1996; en: Corte Interamericana de Derechos Humanos CDH - CP2/96, pág. 2. Ed. Secretaría de la Corte, San José de Costa Rica; 3 de febrero de 1996.

Corte Interamericana de Derechos Humanos: «Caso Genie Lacayo»; en: Corte Interamericana de Derechos Humanos, Informe Anual 1995, págs. 63 a 72 y 79 a 92. OEA, Ser.L./V/III.33; Ed. Secretaría General de la OEA, Washington D.C., Estados Unidos; 22 de enero de 1996.

Corte Interamericana de Derechos Humanos: «Caso Paniagua Morales y Otros». Excepciones Preliminares, Sentencia del 25 de enero de 1996, en Corte Interamericana de Derechos Humanos CDH - CP2/96, pág. 1. Ed. Secretaría de la Corte, San José de Costa Rica, 3 de febrero de 1996.

Corte Interamericana de Derechos Humanos: «Caso Castillo Páez». Sentencia del 30 de enero de 1996; en: Corte Interamericana de Derechos Humanos CDH - CP2/96, págs. 1 y 2. Ed. Secretaría de la Corte, San José de Costa Rica; 3 de febrero de 1996. 
Corte Interamericana de Derechos Humanos: «Caso Loayza Tamayo». Excepciones Preliminares; Sentencia del 31 de enero de 1996; en: Corte Interamericana de Derechos Humanos CDH CP2/96, pág. 2. Ed. Secretaría de la Corte, San José de Costa Rica; 3 de febrero de 1996.

Corte Interamericana de Derechos Humanos: «Caso Blake»: excepciones preliminares. Sentencia del 2 de julio de 1996, en: Corte Interamericana de Derechos Humanos, CDH - CP4/96, pág. 1. Ed. Secretaría de la Corte, San José de Costa Rica, 4 de julio de 1996.

Corte Interamericana de Derechos Humanos: «Caso Suárez Rosero»; en: Corte Interamericana de Derechos Humanos CDH - CP2/96, pág. 3. Ed. Secretaría de la Corte, San José de Costa Rica, 3 de febrero de 1996.

Corte Interamericana de Derechos Humanos: «Caso Benavídez Cevallos»; en: Corte Interamericana de Derechos Humanos, CDH - CP4/96, pág. 3. Ed. Secretaría de la Corte, San José de Costa Rica, 4 de julio de 1996.

Corte Interamericana de Derechos Humanos: «Caso Cantoral Benavides» en: Corte Interamericana de Derechos Humanos CDH - CP6/96, pág. 3. Ed. Secretaría de la Corte, San José de Costa Rica; 8 de octubre de 1996.

Corte Interamericana de Derechos Humanos: «Caso Durand y Ugarte» en: Corte Interamericana de Derechos Humanos CDH - CP6/96, pág. 4. Ed. Secretaría de la Corte, San José de Costa Rica; 8 de octubre de 1996.

Corte Interamericana de Derechos Humanos: «Caso Bámaca Velásquez»en: Corte Interamericana de Derechos Humanos CDH - CP6/96, pág. 4. Ed. Secretaría de la Corte, San José de Costa Rica; 8 de octubre de 1996.

Corte Interamericana de Derechos Humanos: «Informe Anual 1980», Indice: OEA/SER.L/V/III. 3, doc. 13; Secretaría General, Organización de los Estados Americanos, Washington, Estados Unidos, 1981.

Corte Interamericana de Derechos Humanos: «Informe Anual 1981», Indice: OEA/SER.L/V/III. 5, doc. 13; Secretaría General, Organización de los Estados Americanos, Washington, Estados Unidos, 1982.

Corte Interamericana de Derechos Humanos: «Informe Anual 1982», Indice: OEA/SER.L/V/III. 7, doc. 13; Secretaría General, Organización de los Estados Americanos, Washington, Estados Unidos, 1983.

Corte Interamericana de Derechos Humanos: «Informe Anual 1983», Indice: OEA/SER.L/V/III. 9, doc. 13; Secretaría General, Organización de los Estados Americanos, Washington, Estados Unidos, 1984.

Corte Interamericana de Derechos Humanos: «Informe Anual 1984», Indice: OEA/SER.L/V/III. 10, doc. 13; Secretaría General, Organización de los Estados Americanos, Washington, Estados Unidos, 1985.

Corte Interamericana de Derechos Humanos: «Informe Anual 1985», Indice: OEA/SER.L/V/III. 12, doc. 13; Secretaría General, Organización de los Estados Americanos, Washington, Estados Unidos, 1986.

Corte Interamericana de Derechos Humanos: «Informe Anual 1986», Indice: OEA/SER.L/V/III. 15, doc. 13; Secretaría General, Organización de los Estados Americanos, Washington, Estados Unidos, 1987.

Corte Interamericana de Derechos Humanos: «Informe Anual 1987», Indice: OEA/SER.L/V/III. 17, doc. 13; Secretaría General, Organización de los Estados Americanos, Washington, Estados Unidos, 1988.

Corte Interamericana de Derechos Humanos: «Informe Anual 1988», Indice: OEA/SER.L/V/III. 19, doc. 13; Secretaría General, Organización de los Estados Americanos, Washington, Estados Unidos, 1989.

Corte Interamericana de Derechos Humanos: «Informe Anual 1989», Indice: OEA/SER.L/V/III. 21, doc. 14; Secretaría General, Organización de los Estados Americanos, Washington, Estados Unidos, 1991. 
Corte Interamericana de Derechos Humanos: «Informe Anual 1990», Indice: OEA/SER.L/V/III. 23, doc. 12; Secretaría General, Organización de los Estados Americanos, Washington, Estados Unidos, 1991.

Corte Interamericana de Derechos Humanos: «Informe Anual 1991», Indice: OEA/SER.L/V/III. 25, doc. 7; Secretaría General, Organización de los Estados Americanos, Washington, Estados Unidos, 1992.

Corte Interamericana de Derechos Humanos: «Informe Anual 1992», Indice: OEA/SER.L/V/III. 27, doc. 10; Secretaría General, Organización de los Estados Americanos, Washington, Estados Unidos, 1993.

Corte Interamericana de Derechos Humanos: «Informe Anual 1993», Indice: OEA/SER.L/V/III. 29, doc. 4; Secretaría General, Organización de los Estados Americanos, Washington, Estados Unidos, 1994.

Corte Interamericana de Derechos Humanos: «Informe Anual 1994», Indice: OEA/SER.L/V/III. 31, doc. 9; Secretaría General, Organización de los Estados Americanos, Washington, Estados Unidos, 1995.

Corte Interamericana de Derechos Humanos: «Informe Anual 1995», Indice: OEA/SER.L/V/III. 33, doc. 4; Secretaría General, Organización de los Estados Americanos, Washington, Estados Unidos, 1996.

Corte Interamericana de Derechos Humanos: «Informe Anual 1996», Indice: OEA/SER.L/V/III. 35, doc. 4; Secretaría General, Organización de los Estados Americanos, Washington, Estados Unidos, 1997.

Documents d' actualité internationale: N 15, 1er août 1995, París, France, 1995.

Instituto de Relaciones Internacionales: Anuario 1994, Anuario 1995, Anuario 1996 y Anuario 1997; Sección de Derechos Humanos, Ed. IRI, UNLP, La Plata, Argentina, 1994/1997.

Instituto de Relaciones Internacionales: «La Conferencia de Viena: El debate sobre Derechos Humanos en las relaciones internacionales contemporáneas», Ed. IRI, UNLP, La Plata, Argentina, 1993".

Instituto de Relaciones Internacionales: «La protección universal y regional de los derechos humanos», Ed. IRI, UNLP, serie estudios N 6, La Plata, Argentina, 1995.

Instituto de Relaciones Internacionales: «A un año de Beijing: la Conferencia Mundial sobre Derechos de la Mujer», Ed. IRI, UNLP, 1996.

Instituto Interamericano de Derechos Humanos: Revistas Ns 8 a 21, Ed. IIDH, San José de Costa Rica, 1988/1995.

Instituto Interamericano de Derechos Humanos: Serie «Estudios Básicos», Tomos I, II, III, IV, y V; Ed. IIDH, San José de Costa Rica, 1994/1996.

Naciones Unidas: «Derechos Humanos: recopilación de instrumentos internacionales», Ed. Naciones Unidas, New York, Estados Unidos, 1988.

Naciones Unidas: Serie: Derechos Humanos, «Folletos informativos» N 1 al 18, Ed. Ginebra, Suiza, 1988/1992.

Naciones Unidas: Serie: Derechos Humanos: «Puntos de vista de las Naciones Unidas», New York, United States, 1992.

Organización de los Estados Americanos: «Documentos básicos en materia de derechos humanos en el sistema interamericano» (actualizado a mayo de 1996), Ed. Secretaría General, Organización de los Estados Americanos, Washington, Estados Unidos, 1996. 


\section{NOTAS}

1 En el desarrollo que haremos en los próximos Capítulos, se verán las similitudes y diferencias que posee la Corte Interamericana de Derechos Humanos, con algunos otros órganos jurisdiccionales permanentes que existen: la Corte Internacional de Justicia dentro de la Organización de las Naciones Unidas, y el Tribunal Europeo de Derechos Humanos dentro del Consejo de Europa. Ver al respecto, Capítulo IV: «La Corte Interamericana de Derechos Humanos. Competencias y asuntos tratados»; especialmente puntos II.1.- «La competencia consultiva», y II.2.- «La Competencia contenciosa».

2 Convención Americana sobre Derechos Humanos: art. 33. La Organización y funcionamiento de la Corte Interamericana de Derechos Humanos, se encuentran en los artículos 52 a 73 del Pacto de San José. La Corte tiene además un Estatuto, que aprobó la Asamblea General de la Organización de los Estados Americanos mediante Resolución N 448 en su IX Período de Sesiones, celebrado en La Paz, Bolivia, y un Reglamento que adoptó la propia Corte, en su XXIII período ordinario de sesiones en San José de Costa Rica (1991), y fue reformado en cuatro oportunidades, la última de ellas en setiembre de 1996. Todos los textos mencionados pueden verse en: Organización de los Estados Americanos: «Documentos básicos en materia de derechos humanos en el sistema interamericano» (actualizado a abril de 1997); Ed. Secretaría General de la OEA, Washington D.C., Estados Unidos, 1997.

3 Corte Interamericana de Derechos Humanos: «Otros tratados: objeto de la función consultiva de la Corte». Opinión Consultiva OC-1/82 del 24 de setiembre de 1982. Serie A N 1. Ed. Secretaría de la Corte, San José de Costa Rica, 1982.

4 Conf. Cançado Trindade, Antônio: «El Sistema Interamericano de Protección a los Derechos Humanos». Collection of Lectures, Texts and Summaries; Ed. Institut International de Droits De l'Homme, Strasbourg, France, 1993.

5 Corte Interamericana de Derechos Humanos: «Caso Velásquez Rodríguez». Excepciones Preliminares. Serie C, N 1. Sentencia del 26 de junio de 1987. Ed. Secretaría de la Corte, San José de Costa Rica, 1988; y Corte Interamericana de Derechos Humanos: «Caso Godínez Cruz». Excepciones Preliminares. Serie C, N 3. Sentencia del 26 de junio de 1987. Ed. Secretaría de la Corte, San José de Costa Rica, 1988.

6 Corte Interamericana de Derechos Humanos: «Caso Velásquez Rodríguez». Serie C, Resoluciones y Sentencias; N 4. Sentencia del 29 de julio de 1988. Ed. Secretaría de la Corte, San José de Costa Rica, 1988.

7 Hemos realizado un análisis, de la evolución en materia contenciosa de la Corte Interamericana de Derechos Humanos en Salvioli, Fabián: «La justicia como garante de la dignidad humana: las sentencias de la Corte Interamericana de Derechos Humanos contra Estados»; en: Amnistía Internacional, "Revista bimestral para los países de habla hispana", No 20, agosto / setiembre 1996; págs. 31 a 34; Ed. Edai, Madrid, España, 1996.

8 Ver al respecto, Capítulo VI, Punto II.3.- «Para el acceso a la vía internacional del Sistema Interamericano de Derechos Humanos, debe procederse al agotamiento de los recursos internos».

9 Véanse Capítulo V, Punto V.3.- «Otras consideraciones»; y el desarrollo íntegro del Capítulo VIII.

$10 \mathrm{La}$ resolución de esta cuestión teórica ha sido fundamental para el auge y desarrollo de los instrumentos, órganos y mecanismos de protección, en los sistemas internacionales, tanto dentro de la Organización de las Naciones Unidas, como en las Organizaciones Internacionales regionales (éstas últimas se analizan in extenso, en lo concerniente a la protección de los derechos humanos, dentro del Capítulo III. 
11 Véase en el Capítulo III, el análisis realizado del Protocolo IX Anexo al Convenio Europeo de Derechos Humanos, y las consideraciones producidas acerca del Protocolo XI Anexo al mismo instrumento.

12 Que finalizará, sin duda, en el establecimiento de una Corte Penal Internacional Permanente, conforme se viene debatiendo en el seno de la Asamblea General de las Naciones Unidas.

13 Véase el Capítulo III, punto III.2.- «La Protección Extraconvencional».

14 Capítulo VII, Punto II.4.- «Las declaraciones marco de derechos humanos son jurídicamente obligatorias, cuando constituyen la interpretación de los derechos humanos contenidos en los tratados constitutivos de las Organizaciones Internacionales».

15 Ver Capítulo VII, Punto II.1.- «Los tratados de derechos humanos tienen una naturaleza propia, disímil de los tratados comunes en el Derecho Internacional».

16 La versión en francés de la Carta Arabe puede verse en: Al Midani, Mohamed A.: «Charte Arabe des Droits de 1' Homme» (traduction), en: "Revue Universelle des Droits de 1' Homme" Vol. 7 N 4-6, págs. 212 a 214, Strasbourg, France, 1995.

17 El texto en español del Convenio Europeo de Derechos Humanos puede verse en Hitters, Juan C.: «Derecho Internacional de los Derechos Humanos» T. I, págs. 424 a 433; Ed. Ediar, Buenos Aires, Argentina, 1993.

18 El texto de la Carta Africana de Derechos Humanos y de los Pueblos en idioma francés, puede verse en Conseil de l'Europe: «Droits de l'Homme en Droit International», págs. 353 a 374, Ed. Conseil de l'Europe, Bruxelles, Bélgique, 1992.

19 La versión francesa del texto de la Convención puede consultarse en Documents d' actualité internationale, N 15, 1er août 1995, págs. 506 a 510; París, France, 1995.

20 Ver Capítulo III, Punto II.5.- «La Organización de los Estados Americanos».

21 Conf. Villán Durán, Carlos: «Curso de Derecho Internacional de los Derechos Humanos»; partes Tercera y Cuarta; Ed. Institut International des Droits de l'Homme, Strasbourg, France, 1995.

22 Según el artículo 38 del Estatuto de la Corte Internacional de Justicia, en: Zavalía, Víctor: «Recopilación de instrumentos internacionales», pág. 52; Ed. Zavalía, Buenos Aires, Argentina, 1984.

23 Algunos de dichos principios han sido codificados por la Asamblea General de las Naciones Unidas, en su Resolución 2625 (1970); puede verse su texto en: Zavalía, Víctor: «Recopilación ...» Op. Cit.; págs. 84 a 96.

24 Se trata de los casos Velásquez Rodríguez y Godínez Cruz; pueden verse en las ya citadas publicaciones de la Corte Interamericana de Derechos Humanos: «Caso Velásquez Rodríguez». Serie C, Resoluciones y Sentencias; N 4; Sentencia del 29 de julio de 1988. Ed. Secretaría de la Corte; y «Caso Godínez Cruz». Serie C, Resoluciones y Sentencias; N 5.

$25 \mathrm{El}$ texto de la Convención Interamericana sobre Desaparición Forzada de Personas puede consultarse en: Organización de los Estados Americanos: «Documentos básicos ...» Op. Cit. págs. 105 a 111.

26 Convención Americana sobre Derechos Humanos: art.1.1; en: Organización de los Estados Americanos: «Documentos básicos ...» Op. Cit. pág. 30.

27 En aplicación del principio «iura novit curia», (el juez conoce el derecho) que veremos analizado en el Capítulo VI; Punto II.7. 
28 Corte Interamericana de Derechos Humanos: «Caso Velásquez Rodríguez». Serie C, Resoluciones y Sentencias; N 4; Op. Cit., párr. 164, pág. 67; y «Caso Godínez Cruz». Serie C, Resoluciones y Sentencias; N 5; Op. Cit. párr. 173, pág. 71.

$29 \mathrm{Al}$ respecto de este último tópico, la Corte habla de las obligaciones para el Estado, de prevenir, investigar, sancionar las violaciones cometidas, y asegurar a la víctima una adecuada reparación.

30 Ver Carta de las Naciones Unidas (preámbulo párrafo 1), en Zavalía, Víctor: «Recopilación ...» Op. Cit. pág. 11.

31 Para un análisis de la Sociedad de las Naciones véase Díaz Cisneros, César: «Derecho Internacional Público» (Segunda Edición actualizada); Tomo I, págs. 135 a 149. En particular, sobre las causas del fracaso de la Sociedad de las Naciones, ver las págs. 142 a 144. Ed. TEA, Buenos Aires, Argentina, 1966.

32 Conf. Carta de las Naciones Unidas, art. 1. En Zavalía, Víctor: «Recopilación ...»; Op. Cit.; pág. 13.

33 Ibídem, Preámbulo, párrafo II, pág. 11.

34 Puede observarse al respecto Blanc Altemir, Antonio: «La violación de los derechos humanos fundamentales como crimen internacional»; Ed. Bosch S.A., Barcelona, España, 1990.

35 El artículo 13.1.b de la Carta de las Naciones Unidas señala: «... La Asamblea General promoverá estudios y hará recomendaciones para los fines siguientes: ... Fomentar la cooperación internacional en materias de carácter económico, social, cultural, educativo y sanitario y ayudar a hacer efectivos los derechos humanos y las libertades fundamentales de todos, sin hacer distinción por motivos de raza, sexo, idioma o religión». Ver texto en Zavalía, Víctor: «Recopilación ...» Op. Cit. pág. 17.

36 Conf. Consejo Económico y Social: «Resolución 5 / 1», 1946.

37 Conf. Salvioli, Fabián: «La protección de los derechos humanos en el sistema interamericano: sus logros y dificultades»; en: Relaciones Internacionales N 4, pág. 85; Ed. Instituto de Relaciones Internacionales UNLP, La Plata, Argentina, 1993.

38 Ver Sudre, Frédéric: «Droit international et europeén des droits de l'homme», Págs. 30 a 46; Sección II, Capítulo II: «Droit international des droits de l'homme en droit international général», Ed. Presses Universitaires de France, París, France, 1989.

39 Conf. Castro-Rial Garrone, Fanny: «Los derechos humanos y la no intervención en los asuntos internos de los Estados» pág. 200; en Cursos de Derecho Internacional de Vitoria-Gasteiz; Ed. Universidad del País Vasco, Vitoria, España, 1990.

40 Conf Villagrán Kramer, F.: «Los derechos humanos y el principio de no intervención»; en Revista N 13, pág. 96; Ed. Instituto Interamericano de Derechos Humanos, San José de Costa Rica, 1991.

41 El concepto de ius cogens está receptado en la Convención de Viena sobre Derecho de los Tratados de 1969 (art. 63). Sobre el alcance y el carácter de las normas de protección internacional de los derechos humanos en relación al Ius Cogens, véase Pastor Ridruejo, José: «La determinación del contenido del ius cogens», Ponencia del XI Congreso del Instituto Hispano Luso Americano de Derecho Internacional, Madrid, España, 1972; también puede consultarse San José Gil, Amparo: «La protección de los derechos humanos en el ámbito internacional», Ed. Tirant lo Blanch, Valencia, España, 1992.

42 Conf. Buergenthal, Thomas; Grossman, Claudio; y Nikken, Pedro: «Manual Internacional de Derechos Humanos», págs. 173 a 176; IIDH, Ed. Jurídica Venezolana, Caracas, Venezuela 1990. 
43 Para un estudio de la regla véase Cançado Trindade, Antônio: «O esgotamento de recursos internos no Direito Internacional» (285 págs.) Ed. Universidade de Brasilia, Brasilia, Brasil 1984.

44 Nikken, Pedro: «La protección Internacional de los derechos humanos: su desarrollo progresivo»; pág. 116. Ed. Instituto Interamericano de Derechos Humanos / Cívitas, Madrid, España, 1987.

45 Pueden verse distintos textos sobre el punto en análisis. En torno al derecho al desarrollo: García Amador, F.V.: «El Derecho Internacional del desarrollo. Una nueva dimensión del Derecho Internacional económico»; especialmente págs. 68 a 77, Ed. Cívitas, Madrid, España, 1987; Asamblea General: «Declaración sobre el Derecho al Desarrollo», Art. 1. Proclamada por la Asamblea General de la Organización de las Naciones Unidas el 4 de diciembre de 1986; resolución 41/128; World Conference on Human Rights: «The Vienna Declaration and Programme of Action». En: United Nations, New York, August 1993, Parte I, párrafo 10; Declaración de Copenhague sobre Desarrollo Social: B. Principios y Objetivos, párrafo 26.j. Sobre el medio ambiente y el desarrollo como derechos humanos véase Cançado Trindade, Antônio: «Environment and Development: formulation and implementation of the Right to Development as a Human Right»; en: Derechos Humanos, Desarrollo Sustentable y Medio Ambiente; págs. 39 a 64; Ed. IIDH, San José / Brasilia 1992. Finalmente, sobre el derecho a la paz puede consultarse Asamblea General: «Declaración sobre el Derecho de los Pueblos a la Paz», Art. 1. Proclamada por la Asamblea General de la Organización de las Naciones Unidas el 12 de noviembre de 1984; resolución 39/11; Carta Africana de Derechos Humanos y de los Pueblos: Art. 23; en Conseil de l'Europe: «Droits de l'Homme ...» Op. Cit., pág. 361; y Uribe Vargas, Diego: «El derecho a la paz», en: "Derecho Internacional y Derechos Humanos", Editores Daniel Bardonnet y Antônio Cançado Trindade, (págs. 177 a 196) Ed. Academia de Derecho Internacional de La Haya e Instituto Interamericano de Derechos Humanos, San José, Costa Rica / La Haya, Holanda, 1996.

46 Véase Díez de Velasco, Manuel: «Instituciones de Derecho Internacional Público», Tomo I, 9na edición, págs. 58 a 60, Ed. Técnos; Madrid, España 1993.

47 Por medio del Pacto Briand Kellog, los Estados signatarios renunciaban a recurrir a la guerra, como instrumento de política nacional.

48 Conf. Jiménez de Aréchaga, Eduardo: «Principios generales que rigen la conducta de los Estados», Cap. IV, pág. 108; en su libro «El Derecho Internacional Contemporáneo», Ed. Técnos, Madrid, España, 1980.

49 Para estudiar la evolución del Derecho Internacional, véase Carrillo Salcedo, Juan: «El Derecho Internacional en perspectiva histórica»; (219 págs.) Ed. Técnos, Madrid, España, 1991.

50 El Derecho Internacional clásico reconoció que los Estados, tenían deberes en relación a determinadas categorías de individuos; en concreto, el deber de tratar a los extranjeros de acuerdo a ciertos standards mínimos. Pero estos derechos de los extranjeros, intentaban asegurarse no por respeto a su dignidad como personas, sino al Estado del que eran nacionales. De esta forma, las controversias por esta causa se arreglaban por vía diplomática, con la consecuencia negativa, además, de que se encontraban privados de protección los nacionales maltratados en su propio país, y las personas que carecían de nacionalidad.

$51 \mathrm{Si}$ bien pueden mencionarse al respecto las Uniones Administrativas del pasado siglo (Unión Postal Universal y Unión Telegráfica Internacional), es evidente que la Organización Internacional política tuvo su primer intento con la Sociedad de las Naciones; puede consultarse al respecto Colliard, Claude A.: «Instituciones de Relaciones Internacionales», Segunda Parte, pág. 350; Ed. Fondo de Cultura Económica, Madrid, España, 1978.

52 La Comisión de Derechos Humanos de las Naciones Unidas fue una de las primeras en ser creadas dentro de la Organización Internacional por el ECOSOC (en el año 1946). Como causa principal, entre otras, de creación de la Comisión, se encuentra la sensibilidad provocada por los crímenes de lesa humanidad, cometidos durante la segunda guerra mundial. 
53 Ver Carta de las Naciones Unidas: arts. 57, 58, 59, 63 y 64. Podemos citar como ejemplos de los organismos especializados, a la Organización Mundial de la Salud (OMS), la Organización Mundial del Trabajo (OIT), la Organización Mundial de las Naciones Unidas para la Educación, la Ciencia y la Cultura (UNESCO), o el Fondo de las Naciones Unidas para la Infancia (UNICEF).

54 Ver Sudre, Frédéric: «Droit international ...» Op. Cit. De interés sobre el punto que comentamos es la Sección II del Capítulo II: Droit international des droits de l' homme en droit international général, Págs. 30 a 46.

55 Conf. Salvioli, Fabián y Jimena Quesada, Luis: «El individuo y los derechos humanos. Especial referencia al marco regional del Convenio Europeo»; en Relaciones Internacionales, año 4 N 6. (Pág. 64. Ed. Instituto de Relaciones Internacionales (UNLP), La Plata, Argentina, 1994.

56 Para un estudio de la característica de la progresividad en la materia, véase Nikken, Pedro: «La Protección Internacional de los Derechos Humanos. Su desarrollo progresivo», libro al que hemos hecho mención puntual ut supra, ver nota $\mathrm{n}^{\circ} 44$.

57 Conf. Podestá Costa, Luis y Ruda, José María: «Manual de Derecho Internacional Público», Tomo I Cap. II «La personalidad jurídica», pág. 74. Ed. TEA, Buenos Aires, Argentina, 1985.

58 Sobre el agotamiento de los recursos internos, consideramos que la Corte Interamericana de Derechos Humanos ha construído un Postulado tomado del Derecho Internacional General, y el cual desarrollamos en el Capítulo VI.

59 Conf. Carrillo Salcedo, Juan: «Soberanía de los Estados y Derechos Humanos en Derecho Internacional Contemporáneo»; pág. 131. Ed. Técnos, Madrid, España, 1995.

60 Así lo hemos sostenido en Salvioli Fabián: «La tutela de los derechos en el sistema interamericano»; en Revista Tribuno, Publicación del Colegio de Abogados de la Primera Circunscripción de la Provincia de Córdoba; año 2 N 6, Págs. 157 a 163, Córdoba, Argentina, 1995.

61 Conf. Podestá Costa, Luis y Ruda, José María: «Manual ... Op. Cít., pág. 57.

62 Conf. García Girelli: «Repertorio de jurisprudencia de la Corte Internacional de Justicia», pág. 157; Ed. Zavalía, Buenos Aires, Argentina, 1973.

63 «Reparación de perjuicios sufridos al servicios de las Naciones Unidas», en: Cour International de Justice, Recueil 1949.

64 El ejemplo más acabado de lo que señalamos, se da en el proceso de integración económica iniciado en Europa Occidental a principios de la década de 1950, y consolidado hoy en la llamada Unión Europea.

65 Véase el alcance del principio de libre determinación de los pueblos, en la Resolución 2625 (1970) de la Asamblea General de las Naciones Unidas.

66 Conf. Asamblea General: Resolución 1514 «Declaración sobre la concesión de la independencia a los paises y los pueblos coloniales»; aprobada el 14 de diciembre de 1960.

67 Asamblea General: «Declaración sobre el Derecho al Desarrollo», Art. 1. Proclamada por la Asamblea General de la Organización de las Naciones Unidas el 4 de diciembre de 1986; resolución 41/128.

68 La descripción del Nuevo Orden Económico Internacional, puede verse en García Amador, F.V.: «El Derecho Internacional del desarrollo. Una nueva dimensión ...» Op. Cit. Especialmente, consultar Págs. 38 a 42. 
69 Carta Africana de Derechos Humanos y de los Pueblos: Art. 23; en Conseil de l'Europe: «Droits de l'Homme ...» Op. Cit. pág. 361.

70 Ver Ranjeva, Raymond y Cadoux, Charles: «Droit International Public»; Titre IV, Le peuple en droit international; especialmente págs. 137 a 144; Ed. Edicef/Aupelf, Universités Francophones, Paris, France, 1992.

71 Conf. Gros Espiell, Héctor: «El derecho a la libre determinación de los Pueblos y los Derechos Humanos»; en: "Estudios sobre Derechos Humanos Tomo I", especialmente pág. 195. Ed. Jurídica Venezolana, Caracas, Venezuela, 1985.

72 Ver Mariño Menéndez, Fernando: «Derecho Internacional Público (parte general)»; pág. 74; Ed. Trotta, Madrid, España, 1993.

73 Conf. Díez de Velasco, Manuel: «Instituciones ...» Op. Cit., Tomo I, págs. 288 a 292.

74 Conf. Barberis, Julio: «Los sujetos del Derecho Internacional», pág. 146, Ed. Técnos, Madrid, España, 1984.

75 Conf. Sudre, Frédéric: «Droit International ...» Op. Cít. pág. 56 (traducción no oficial, hecha por el autor).

76 Conf. Jiménez de Aréchaga, Eduardo: «El Derecho Internacional Contemporáneo ...» Op. Cít. pág. 208.

77 Conf. Protocolo Facultativo del Pacto Internacional de Derechos Civiles y Políticos: art. 1 (en vigor desde el 23 de marzo de 1976); en Naciones Unidas: «Derechos Humanos, recopilación de instrumentos internacionales», pág. 38. Ed. Naciones Unidas, New York, Estados Unidos, 1988.

78 Conf. Villán Durán, Carlos: «Curso de Derecho Internacional ...» Op. Cit. pág. 185.

79 Conf. Artículo 25 del Convenio Europeo de Derechos Humanos (adoptado en la ciudad de Roma, 1950).

80 Ver sobre la Convención Europea, Castro-Rial Garrone, Fanny: «El Sistema Europeo de Derechos Humanos»; en: "La protección universal y regional de los derechos humanos"; págs. 39 a 63; Ed. Instituto de Relaciones Internacionales UNLP, La Plata, Argentina, 1995.

81 Conf. Salvioli, Fabián y Jimena Quesada, Luis: «El individuo y los derechos humanos ...» Op. Cít., pág. 76.

82 Véase al respecto el libro de Sánchez Legido, Angel: «La reforma del mecanismo de control del Convenio Europeo de Derechos Humanos»; Ed. Colex; Madrid, España, 1995.

83 Reglamento de la CIDH: Art. 26, Presentación de peticiones. En Organización de los Estados Americanos: «Documentos básicos ...» Op. Cit. pág. 92.

84 Conf. Salvioli, Fabián: «El Sistema Interamericano de protección de los Derechos Humanos», en Recueil des cours, textes et sommaires, XXVII Session d'Enseignement, pág. 309, Ed: Institut International des Droits de l' Homme; Strasbourg, France, 1996.

85 Conf. Pastor Ridruejo, José: «Curso de Derecho Internacional Público y Organizaciones Internacionales», 4ta Edición, pág. 210, Ed. Técnos, Madrid, España, 1992. 
86 Conf. art. 23 del nuevo Reglamento de la Corte Interamericana de Derechos Humanos, aprobado durante el XXXIV Período Ordinario de Sesiones, el 16 de setiembre de 1996. Este Reglamento, entró en vigor el 1 de enero de 1997.

87 Ver, particularmente, Capítulo VI; punto II.9.- «El daño producido por la violación de una norma de Derecho Internacional, engendra el derecho a una reparación adecuada».

88 Conf. Puig, Juan C.: «Derecho de la Comunidad Internacional»; pág. 25, Ed. Depalma, Buenos Aires, Argentina, 1986.

89 Ver Consejo de Seguridad de las Naciones Unidas: Resolución 808/93, por la cual se crea el Tribunal Internacional para la ex Yugoslavia, y Resolución 955/94, por la cual se crea el Tribunal Internacional para Rwanda.

90 Conf. Salvioli, Fabián: «Relaciones Internacionales, Derechos Humanos y Educación para la Paz»; en: "Human Rigths: The Promise for the XXIst Century / Direitos Humanos: A promessa do século XXI"; pág. 292, Ed. Universidade Portucalense, Oporto, Portugal, 1997.

91 Para estudiar el funcionamiento y composición de dicho Tribunal, véase Lescure, Karine: «Le Tribunal Pénal International pour L'ex Yougouslavie; 201 págs, Ed. Cedin - Paris I, Paris, France, 1994.

92 Ver Consejo de Seguridad: Anexo Resolución 827 (93). Estatuto de funcionamiento del Tribunal para la Ex Yugoslavia.

93 Nos referimos a la Convención de Viena sobre Derecho de los Tratados de 1969, y a la Convención de Viena sobre Derecho de los Tratados de 1986, bases del «Derecho Internacional convencional».

94 Convención sobre Derecho de los Tratados (1969): art. 2,1.a).

95 Conf. Sorensen, Max: «Manual de Derecho Internacional Público», pág. 201; cuarta reimpresión al español, México, 1992.

96 Véase al respecto, Chueca Sancho, Angel: «Las reservas a los Tratados de Derechos humanos»; en: Documentación Jurídica T XIX N 74, págs. 195 a 357; abril - junio de 1992. Ed. Ministerio de Justicia, Madrid, 1992.

97 Conf. O'Donnell, Daniel: «Protección internacional de los derechos humanos», pág. 16, Ed. Comisión Andina de Juristas, Lima, Perú, 1988.

98 Asamblea General: Resolución 217, A, 3; en Naciones Unidas: «Derechos Humanos, recopilación...» Op. Cit. págs 1 a 7.

99 Proclamación de Teherán (1968): art. 2; en Ibídem, págs. 42/3.

100 Conf. Hitters, Juan C.: «Derecho Internacional de los Derechos Humanos...» Op. Cit. Tomo I, pág. 138; Ed. Ediar, Buenos Aires, Argentina, 1991.

101 Véase al respecto Carrillo Salcedo, Juan A.: «Algunas reflexiones sobre el valor jurídico de la Declaración Universal de Derechos Humanos», Ed. Técnos, Madrid, España, 1993.

102 Estos procedimientos tienen una serie de requisitos que escapan al presente estudio. Es altamente recomendable la publicación de Escobar Hernández, Concepción: «Algunas consideraciones críticas sobre el funcionamiento de los mecanismos extraconvencionales de control establecidos por la Comisión de Derechos Humanos de las Naciones Unidas» en: "Hacia una justicia universal", Ed. Comisión Internacional de Juristas, Ginebra, Suiza, 1993. 
103 Ver Comisión Interamericana de Derechos Humanos, Caso 9647. CIDH Resolución 3/87. Informe Anual de la CIDH 1986/87, Organización de Estados Americanos, Washington D.C; Estados Unidos, 1987.

104 Corte Interamericana de Derechos Humanos: «Interpretación de la Declaración de los Derechos y Deberes del Hombre en el marco del artículo 64 de la Convención Americana sobre Derechos Humanos» Opinión Consultiva OC-10/89 del 14 de julio de 1989. Serie A N 10. Ed. Secretaría de la Corte, San José, Costa Rica, 1989.

105 Ver Capítulo VII, Punto II.4.- «Las declaraciones marco de derechos humanos son juridicamente obligatorias, cuando constituyen la interpretación de los derechos humanos contenidos en los tratados constitutivos de las Organizaciones Internacionales».

106 Ver al respecto Dupuy, Pierre-Marie: «Droit International Public», pág. 152; Ed. Dalloz, Paris, France, 1993.

107 Conf. Corte Interamericana de Derechos Humanos: «El efecto de las reservas sobre la entrada en vigencia de la Convención Americana de Derechos humanos (arts. 74 y 75)», Opinión Consultiva OC-2/82 del 24 de setiembre de 1982, párr. 29. Serie A N 2. Ed. Secretaría de la Corte, San José, Costa Rica, 1982.

108 Volvemos a este punto en el Capítulo VII, Punto II.1.- «Los tratados de derechos humanos tienen una naturaleza propia, disímil de los tratados comunes en el Derecho Internacional».

109 Conf. Convención Interamericana para Prevenir, Sancionar y Erradicar la Violencia contra la Mujer (1994): art. 3.

110 Conf. Convención sobre Derecho de los Tratados (1969): art. 53.

111 Pastor Ridruejo, Rafael: «La determinación del contenido del ius cogens ...», Op. Cit., Madrid, España, 1972.

112 Conf. Carrillo Salcedo, Juan: «Soberanía de los Estados y Derechos Humanos ...» Op. Cít. págs. 106 y ss.

113 Conf. Travieso, Juan A.: «Derechos Humanos y Derecho Internacional», Cap. V: Los derechos humanos fundamentales; pág. 124; Ed. Heliasta, Buenos Aires, Argentina, 1990.

114 Conf. Sudre, Frédéric: «Droit International ...», Op. Cít. pág. 54.

115 Citamos como ejemplo ilustrativo de lo señalado, a la Cumbre de la Tierra (ECO 92), reunión internacional celebrada en Río de Janeiro, en la que se adoptó la Convención sobre Cambios Climáticos.

116 Para un análisis de los debates producidos y las conclusiones arribadas, véase Cançado Trindade, Antônio: «Balance de los resultados de la Conferencia Mundial de Derechos Humanos», en: Estudios básicos de Derechos Humanos III, Ed. IIDH, San José de Costa Rica, págs. 17 a 46, mayo de 1995; asimismo, puede consultarse Salvioli, Fabián: «La Conferencia de Viena: el Debate sobre Derechos Humanos en las Relaciones Internacionales Contemporáneas» en Relaciones Internacionales. Serie Documentos, N 4; págs 7 a 23; Ed. IRI, Universidad Nacional de La Plata, La Plata, Argentina, 1993.

117 Para un estudio de la Conferencia de El Cairo, véase Lindgren Alves, J.A.: «Población, desarrollo y derechos: la Conferencia de El Cairo de 1994»; En: "Estudios Básicos de Derechos Humanos III"; Op. Cit. págs. 211 a 236.

118 Cumbre Mundial sobre Población y Desarrollo: Programa de Acción, en: Naciones Unidas: A/CONF/171/13; El Cairo, 1994. 
119 Cumbre Mundial sobre Desarrollo Social: Declaración de Copenhague, Primera Parte, B. Principios y Objetivos; Copenhague, Dinamarca, 1995.

120 Ver Cumbre Mundial sobre Desarrollo Social: Programa de Acción; Naciones Unidas, Copenhague, Dinamarca, 1995.

121 Ver al respecto, Salvioli, Fabián: «La mujer en el Derecho Internacional Público: un viaje de medio siglo desde San Francisco a Pekín»; en: A un año de Beijing; págs. 7 a 31, Edit. Instituto de Relaciones Internacionales UNLP, Serie Documentos N 13, La Plata, República Argentina, 1996.

122 Conf. Salvioli, Fabián: Anuario 1996, Sección de Derechos Humanos, Presentación, pág. 246; Ed. Instituto de Relaciones Internacionales, La Plata, Argentina, 1996. Un análisis completo de los derechos de la mujer puede observarse en el Tomo IV de la Serie Estudios Básicos del Instituto Interamericano de Derechos Humanos, dedicado a la cuestión; Ed. IIDH, (340 págs.) San José, Costa Rica, 1996.

123 Ver Declaración y Plataforma de Acción de Pekín sobre Derechos de la Mujer: Pekín, China, 1995; en Naciones Unidas: A/CONF.177/20.

124 Hemos estudiado la cuestión en Salvioli Fabián: «Algunas tendencias sobre derechos humanos en las relaciones internacionales y el Derecho Internacional de la posguerra fría» (investigación llevada adelante para el Instituto Interamericano de Derechos Humanos de San José de Costa Rica, en proceso de edición en el Anuario 1996/97, Centro de Estudios Avanzados de la Universidad Nacional de Córdoba, Cordoba, Argantina, 1997).

125 Conf. Carrillo Salcedo, Juan A.: «Curso de Derecho Internacional Público», pág. 123, Ed. Técnos, Madrid, España, 1991.

126 La Comisión de Derechos Humanos fue creada en 1946. Para conocer su labor véase Marie, Jean Bernard: «La pratique de la Comission des Droits de l'Homme de l' O.N.U. en matière de violations des droits de l' Homme» (Revue Belge de Droit International, Vol. X), Bruxelles, Belgique, 1980.

127 La evolución del Derecho Internacional de los Derechos Humanos dentro de la ONU ha pasado por la adopción de pactos internacionales generales y convenciones específicas. También existe una tarea de protección sumamente importante, que llevan a cabo la Comisión y la Subcomisión de Derechos Humanos de las Naciones Unidas. Para profundizar sobre esto último véase al ya citado trabajo supra, de la profesora Escobar Hernández, Concepción: «Algunas consideraciones críticas sobre el funcionamiento de los mecanismos extraconvencionales de control establecidos por la Comisión de Derechos Humanos de las Naciones Unidas».

128 Un análisis de la Conferencia Mundial puede verse en Cançado Trindade, Antonio: «Memória da Confêrencia Mundial de Direitos Humanos»; en: Boletim de Sociedade Brasileira de Direito Internacional; Año XLVI Junho/Dezembro 1993 N 87/90; Brasilia, Brasil, 1993. Asimismo, hemos realizado un seguimiento de la Conferencia Mundial, en Salvioli, Fabián: «La Conferencia de Viena de Naciones Unidas. Esperanzas y frustraciones en materia de derechos humanos»; en: "Human Rigths: The Promise for the XXIst Century / Direitos Humanos: A promessa do século XXI ..."; Op. Cit. págs. 19 a 37.

129 Por cierto, puede señalarse la labor de la Corte Internacional de Justicia y de los tribunales ad hoc creados para la Ex Yugoslavia y Rwanda, pero estos no son asimilables a las respectivas composiciones y funciones, del Tribunal Europeo de Derechos Humanos y de la Corte Interamericana de Derechos Humanos. Para un análisis del trabajo judicial de derechos humanos en Naciones Unidas véase Villán Durán, Carlos: «Curso de Derecho Internacional ...»; Op. Cit. págs. 215 a 224.

130 Ver Vasak, Karol: «Las dimensiones internacionales de los derechos humanos»; ed. Serbal / UNESCO. T III, Pág. 621. París, Francia, 1984. 
131 Véase como iniciación al tema Piza, Rodolfo: «La Coordinación de los Mecanismos de la Convención Americana sobre Derechos Humanos con respecto a los establecidos por el sistema de las Naciones Unidas para la promoción y protección de los derechos humanos» en: "La Convención Americana Sobre Derechos Humanos", págs. 191 a 212, Ed. OEA Washington DC, Estados Unidos, 1980.

132 Véase al respecto Cançado Trindade, Antônio: «Alalyses of the legal implications for states that intend to ratify both the European Convention on Human Rights and its Protocols and the Convention on Human Rights of the Commonwealth of Independent States»; en Council of Europe SG/INF (95) 17; págs. 2 a 33; Strasbourg, France, 1995.

133 Conf. Hitters, Juan C.: «Derecho Internacional de los Derechos Humanos» Op. Cit. Tomo I, pág. 54.

134 Conf. Gros Espiell, Héctor: «La Convención Americana y la Convención Europea de Derechos Humanos: análisis comparativo»; págs. 13 y 14; Ed. Jurídica de Chile, Santiago, Chile, 1991.

135 Para un análisis comparativo entre los sistemas regionales (particularmente el europeo y el interamericano) véase Albanese, Susana: «Algunas comparaciones entre los sistemas regionales de promoción y protección de los derechos humanos», en: "El Derecho, 135:927" Buenos Aires, Argentina.

136 Existen algunas obras sobre la Liga de Estados Arabes y los Derechos Humanos; a título de mención, simplemente, señalamos las siguientes: Marks, Stephen: «La Comission Permanente Arabe des Droits de 1' Homme», en: "Revue Universelle des Droits de 1' Homme", Vol. 3 N 1, pág. 102, Strasbourg, France, 1970; Boutros-Ghali, Boutros: «La Liga de Estados Arabes», en: "Las dimensiones internacionales de los derechos humanos ...", Op. Cit. Tomo III, págs. 746 a 752.

137 Conf. Al Midani, Mohamed Amín: «La Liga de Estados Arabes y los Derechos Humanos»; en: "La protección universal y regional de los derechos humanos"; Op. Cit. págs. 13/4.

138 El Consejo de la Liga de Estados Arabes, adoptó la Carta Arabe en su Resolución 5437, del 15 de setiembre de 1994.

139 Ver el texto de la Carta Arabe en Al Midani, Mohamed A.: «Charte Arabe des Droits de l'Homme» (traduction), en: "Revue Universelle des Droits de 1' Homme" Vol. 7 N 4-6, págs. 212 a 214, Strasbourg, France, 1995.

140 Ver al respecto Rishmawi, R.: «Human Rights developments within the League of Arab States and in Asia», en: "Recueil des cours", textes et sommaires, XXVII Session d'Enseignement, págs. 366/67, Ed: Institut International des Droits de l' Homme; Strasbourg, France, 1996.

141 Más concretamente, al 1 de enero de 1996 no poseía ninguna ratificación, conf. Marie, Jean Bernard: «Instruments internationaux relatifs aux droits de l'Homme. Classification et état des ratification au 1er Janvier 1996; En Human Rights Law Journal Vol. 17 N 1-2, pág. 82; N.P. Engel, Publisher, Strasbourg, France, 1996.

142 Conf. Castro-Rial Garrone, Fanny: «El Sistema Europeo de Derechos Humanos ...»; Op. Cit. pág. 40.

143 Sírvase de ejemplo el Protocolo I Anexo al Convenio Europeo de Derechos Humanos, que contempla el derecho a la educación y el derecho a la propiedad. (Este Protocolo ha sido adoptado en parís en 1952).

144 Conf. Hitters, Juan C.: «Derecho Internacional ...» Op. Cit., Tomo I, pág. 272.

145 Conf. Vasak, Karol: «Las dimensiones ...» Op. Cit.; T III pág. 625.

146 Hay distintos análisis sobre la Carta Africana; aqui subrayamos los siguientes: Amnistía Internacional: «Guía de la Carta Africana de los Derechos Humanos y de los Pueblos»; Ed. Edai, Madrid, 
España, 1991. Buergental, Thomas: «Human Rigths, In a nut shell», Ed. West, Minessotta, United States, 1988. Cáp. 5, Págs. 171/186. Castro Rial Garrone, Fanny: «La Carta Africana de Derechos Humanos y de los pueblos», en: "Revista Española de Derecho Internacional", Vol XXXVI, N 2, Madrid, España, 1984; y Degni - Segui, R: «La Charte africane des droits de l' Homme et des Peuples», en: "Recueil des Cours, Collection of Lectures, Texts and Summaries"; Ed. Institut International de Droits de 1' Homme, Strasbourg, France, 1993.

147 Ver al respecto Colliard, Claude A.: «Instituciones de Relaciones Internacionales» Op. Cit. Segunda Parte, pág. 558.

148 Conf. Buergenthal, Thomas; Grossman, Claudio; y Nikken, Pedro: «Manual Internacional de Derechos Humanos», Op. Cit. pág. 116.

149 Carta Africana de Derechos Humanos: Arts. 2 a 18; en Conseil de l'Europe: «Droits de l'Homme ...» Op. Cit. págs. 355 a 369.

150 Ibídem, arts. 19 a 24; en Ibídem, págs. 359 a 361.

151 Ibídem, arts. 1, 25 y 26; en Ibídem, págs. 355, 361 y 362.

152 Ibídem, arts. 27 a 29; en Ibídem, págs. 362 y 363.

153 Una descripción del contenido de la Convención de Minsk sobre Derechos Humanos de la Comunidad de Estados Independientes (adoptada en Bielorrusia) puede verse en Instituto de Relaciones Internacionales: «Anuario 1996» (Sección de Derechos Humanos), Op. Cit. págs. 318 y 319.

$154 \mathrm{La}$ versión francesa del texto de la Convención puede consultarse en "Documents d' actualité internationale", N 15, 1er août 1995, págs. 506 a 510; París, France, 1995.

155 Conf. Colliard, Claude A.: «Instituciones ...» Op. Cit. págs. 416 a 420.

156 Ver Declaración Americana de los Derechos y Deberes del Hombre, Preámbulo; párr. 2; en: Organización de los Estados Americanos: «Documentos básicos ...» Op. Cit. pág. 19.

157 Ver al respecto Corte Interamericana de Derechos Humanos: «Caso Velásquez Rodríguez». Serie C, Resoluciones y Sentencias; N 4; párr. 154, Op. Cit. págs. 62/63; «Caso Godínez Cruz». Serie C, Resoluciones y Sentencias, N 5; párr. 162, Op. Cit. pág. 66; y «Caso Neira Alegría y otros». Sentencia del 19 de enero de 1995; párr. 75; en: Corte Interamericana de Derechos Humanos, "Informe Anual 1995"; págs. 41 a 62. Ed. Secretaría General de la Organización de los Estados Americanos, Washington D.C., Estados Unidos, 1996.

158 Adoptada por la Resolución XXX de la Novena Conferencia Internacional de los Estados Americanos, celebrada entre el 30 de marzo y el 2 de mayo de 1948 en Bogotá, Colombia.

159 Adoptada en San José, Costa Rica, el 22 de noviembre de 1969, en la Conferencia Especializada Interamericana sobre Derechos Humanos. La Convención entró en vigor el 18 de julio de 1978.

160 El Primer Protocolo anexo a la Convención Americana sobre Derechos Humanos, es en materia de Derechos Económicos, Sociales y Culturales (Protocolo de San Salvador), y ha sido adoptado el 17 de noviembre de 1988, en el XVIII Período de Sesiones de la Asamblea General. Por su parte, el Segundo Protocolo es relativo a la abolición de la pena de muerte (Protocolo de Asunción), ha sido adoptado el 8 de junio de 1990, en el XX Período de Sesiones de la Asamblea General, y ha entrado en vigor el 28 de agosto de 1991. 
161 Adoptada en Cartagena de Indias, Colombia, el 9 de diciembre de 1985, en el XV Período de Sesiones de la Asamblea General. La Convención entró en vigor el 28 de febrero de 1987.

162 Adoptada en Belem do Pará, Brasil, el 9 de junio de 1994, en el XXIV Período de Sesiones de la Asamblea General. La Convención entró en vigor el 29 de marzo de 1996.

163 Adoptada en Belem do Pará, Brasil, el 9 de junio de 1994, en el XXIV Período de Sesiones de la Asamblea General. La Convención entró en vigor el 5 de marzo de 1995.

164 No obstante, hay diferencias sustanciales entre la Convención Americana y la Europea. Puede verse al respecto Buergenthal, Thomas: «Las Convenciones Europea y Americana: algunas similitudes y diferencias»; en: "La Convención Americana sobre Derechos Humanos...", Op. Cit. págs. 178 a 190. Para un estudio extenso sobre el tema véase el trabajo citado citado supra del tratadista uruguayo Gros Espiell, Héctor: «La Convención Americana y la Convención Europea de Derechos Humanos. Análisis comparativo ...» (supra, Nota 134).

165 Para un estudio de la problemática de los derechos económicos y sociales en la región, véase: Mignone, Emilio: «Los derechos económicos, sociales y culturales en las constituciones políticas de los países del cono sur de América»; en: "Estudios Básicos de Derechos Humanos", Tomo V; págs. 17 a 50; Ed. Instituto Interamericano de Derechos Humanos; San José de Costa Rica, 1996; véase también Ordoñez, Jaime y Vazquez, Enrique: «Derechos Económicos y Desarrollo en América Latina». Ed. IIDH, San José, Costa Rica, 1991.

166 Conf. Grossman, Claudio: «Reflexiones sobre el sistema interamericano de protección y promoción de los derechos humanos» en: "La Corte y el Sistema Interamericanos de Derechos Humanos", pág. 249; Ed. Insituto Interamericano de Derechos Humanos, San José, Costa Rica, 1994.

167 Si bien dentro de la Organización de las Naciones Unidas, la Corte Internacional de Justicia se ha referido a aspectos de derechos humanos, y existen dos tribunales penales internacionales ad hoc (para los conflictos de la Ex Yugoslavia y Rwanda). Asimismo, las discusiones sobre el establecimiento de una corte penal internacional con carácter permanente se encuentran en un grado importante de avance. Por último, en el seno de la Organización para la Unidad Africana, desde 1993 la Comisión Africana de Derechos Humanos y de los Pueblos estudia un borrador de Protocolo Facultativo para crear una Corte Africana de Derechos Humanos; pero este debate está prácticamente paralizado, por falta de voluntad política de los gobiernos de la región.

168 Conf. Villán Durán, Carlos: «Curso de Derecho Internacional ...» Op. Cit. págs. 159 a 332.

169 Ibídem, pág. 159.

170 Art. 40, en Naciones Unidas: «Derechos Humanos: Recopilación de instrumentos internacionales», Op. Cit. págs. 31/2.

171 Arts. 16 y 17, en Ibídem, págs. 14/5.

172 Art. 9, en Ibídem, págs. 61/2.

173 Art. 18, en Ibídem, pág. 122.

174 Art. VII, en Ibídem, pág. 72.

175 Art. 19, en Ibídem, págs. 218/9.

176 Art. 12, en Ibídem, pág. 81. 
177 Art. 44, en: Naciones Unidas: «Derechos Humanos, Los Derechos del Niño»; Folleto Informativo N 10, págs. 29/30, Ed. Naciones Unidas, Ginebra, Suiza, 1990.

178 Art. 73, en: «Convención Internacional sobre la Protección de los Derechos de Todos los Trabajadores Migratorios y de sus Familiares»; pág. 33, Ed. Centro Scalabriniano de Estudios Migratórios, Brasilia, Brasil, 1994.

179 Para observar el proceso de creación del Comité, véase Naciones Unidas: «Derechos Humanos, Comité de Derechos Económicos, Sociales y Culturales»; Folleto Informativo N 16, págs. 4/5, Ed. Naciones Unidas, Ginebra, Suiza, 1990.

180 Conf. Al Midani, Mohamed Amín: «La Liga de Estados Arabes y los Derechos Humanos ...», Op. Cit. págs. 17/18.

181 Conf. Carta Africana de Derechos Humanos: Art. 62; en Conseil de l'Europe: «Droits de 1'Homme ...» Op. Cit. Pág. 372.

182 Conf. Villán Durán, Carlos: «Curso de Derecho Internacional ...» Op. Cit. pág. 191.

$183 \mathrm{La}$ diferencia reside en que, dentro de la Convención para la Eliminación de todas las formas de Discriminación Racial, este mecanismo es obligatorio para todos los Estados Partes. Por el contrario, en las otras tres convenciones mencionadas, la aceptación del mecanismo es facultativa para los Estados Partes, quienes deben formular, para el caso de que reconozcan el procedimiento en su contra, una declaración especial al respecto.

184 Art. 24 del Convenio Europeo, en: Conseil de l'Europe: «Droits de l'Homme ...», Op. Cit., pág. 177.

185 Conf. Convención Americana sobre Derechos Humanos: art. 45, en: Organización de los Estados Americanos: "Documentos básicos ..." Op. Cit. pág. 38.

186 Conf. Carta Africana de Derechos Humanos: Art. 62; en: Conseil de l'Europe: «Droits de l'Homme ...» Op. Cit. págs. 369/9.

187 Citamos como ejemplos los casos Austria c/ Italia, Application N 788/60; Irlanda c/ Reino Unido, Sentencia de la Corte Europea del 18 de enero de 1978; Dinamarca y otros c/ Grecia, Applications Ns. 332126/67 y 3344/67; Grecia c/ Reino Unido, Application N 4448/70; y Chipre c/ Turquía, Applications Ns. $6780 / 74$ y $7950 / 75$.

188 Art. 25 del Convenio Europeo, en: Conseil de l'Europe: "Droits de l'Homme ...", Op. Cit., pág. 177.

189 La Carta Africana, también somete a la petición iniciada frente a la Comisión Africana de Derechos Humanos y de los Pueblos, al cumplimiento de ciertos requisitos de admisibilidad. El primero de ellos es común en materia de Derecho Internacional, y consiste en la exigencia de que el peticionario, haya agotamiento previamente los recursos internos. También se exige que las comunicaciones no estén basadas exclusivamente en noticias difundidas a través de los medios masivos de comunicación.

190 Buergenthal, Thomas: «International Human Rights in a nutshell», Op. Cit. pág. 186.

191 Cfr. Degni - Segui, R.: «Les droits de l'homme en Afrique Noire Francophone», en: "Recueil des Cours, XXIII Session d'Enseignement" (2 - 31 juilliet 1992). Edit. Institut International des Droits de l'Homme, Strasburg, France, 1992.

192 Conf. art. 38 de la Convención; en: "Documents d' actualité internationale", N 15, Op. Cit., pág. 510. 
193 Ver Regulations of the CIS Comission, secciones II y III; un interesante estudio ha sido realizado sobre los Estados que puedan ser partes en la Convención de la CEI y el Convenio Europeo del Consejo de Europa. Ver el citado trabajo de Cançado Trindade, Antônio: «Alalyses of the legal implications for states that intend to ratify both the European Convention on Human Rights and its Protocols and the Convention on Human Rights of the Commonwealth of Independent States»; Op. Cit.; págs. 2 a 33.

194 Conf. Escobar Hernández, Concepción: «Las Organizaciones Internacionales en América», en: Diez de Velasco, Manuel: "Las Organizaciones Internacionales" (novena edición), Op. Cit. Cap. XXX, pág. 562.

195 Reglamento de la CIDH: Art. 26, Presentación de peticiones; en: Organización de los Estados Americanos: «Documentos básicos ...» Op. Cit. pág. 92.

196 El artículo 25 de la actual Convención Europea de Derechos Humanos (Tratado de Roma de 1950), establece que la Comisión Europea puede conocer de cualquier demanda que provenga de una persona física, organización no gubernamental o grupo de particulares que se considere víctima de una violación a alguno de los derechos reconocidos en aquella. A partir de la entrada en vigor del Protocolo XI, desaparecerá la Comisión Europea, pero subsistirá el requisito de poseer la calidad de víctima para incoar una demanda ante el nuevo Tribunal Europeo de Derechos Humanos.

197 Reglamento de la CIDH: Art. 32, Requisitos de las peticiones; en: Organización de los Estados Americanos: «Documentos básicos ...» Op. Cit. pág. 94.

198 Convención Americana de Derechos Humanos Art. 46, b); Reglamento de la CIDH: Arts. 38.1; 38.2 y 52; todos en: Organización de los Estados Americanos: «Documentos básicos ...» Op. Cit. págs. 38; 96 y 101 , respectivamente.

199 Convención Americana sobre Derechos Humanos: art. 47.d.; en Ibídem, pág. 47.

200 Conf. Jimena Quesada, Luis: «Le systéme interaméricain de protection des droits de l' homme», en: "Recueil des Cours": Collection of Lectures, Textes et Sommaires; Institut International des Droits de 1' Homme, Strasbourg, France, julliet de 1995, págs. 163 a 199.

201 Para un estudio exhaustivo de la regla véase el ya citado libro de Cançado Trindade, Antonio: «O esgotamento de recursos internos no Direito Internacional» Ed. Universidade de Brasilia, 1984.

202 conf. Buergenthal, T.; Norris, R. y Shelton, D.: «La protección de los derechos humanos en las Américas». Instituto Interamericano de Derechos Humanos, pág 317. Ed. Civitas, Madrid, España, 1990.

203 Corte Interamericana de Derechos Humanos: «Excepciones al agotamiento de los recursos internos (Art. 46.1, 46.2.a y 46.2.b Convención Americana sobre Derechos Humanos)». Opinión Consultiva OC/11 del 10 de agosto de 1990. Serie A N 11, Ed. Secretaría de la Corte, San José, 1990.

204 Conf. Corte Interamericana de Derechos Humanos: «Caso Velásquez Rodríguez», Excepciones Preliminares, Op. Cit. Se realizará un análisis exhaustivo de la jurisprudencia de la Corte (y de este caso en particular), infra, en el Capítulo VI.

205 Reglamento de la Comisión Interamericana de Derechos Humanos: art. 37, inc. 2.; en: Organización de los Estados Americanos: «Documentos básicos ...» Op. Cit. pág. 96.

206 Ibídem: art. 37 inc. 3., en Ibidem, pág. 96.

207 Convención Americana sobre Derechos Humanos: art. 48.1.f); y Reglamento de la Comisión Interamericana de Derechos Humanos: artículo 45; en Organización de los Estados Americanos: «Documentos básicos ...», págs. 40 y 98 respectivamente. 
208 Pinto, Mónica: «La denuncia ante la Comisión Interamericana de Derechos Humanos», Ed. Del Puerto, pág. 130, Buenos Aires, Argentina, 1993.

209 Convención Americana sobre Derechos Humanos: art. 51; en Organización de los Estados Americanos: «Documentos básicos ...» Op. Cit. pág. 40.

210 Nos hemos referido a esta cuestión en el Capítulo anterior, en el Punto III.2.b.- «La legitimación pasiva y la responsabilidad internacional».

211 Conf. Villán Durán, Carlos: «Curso de Derecho Internacional ...» Op. Cit. pág. 215.

212 Ibídem, pág. 217 a 221. El autor menciona los 16 tratados de derechos humanos celebrados en Naciones Unidas, que tienen cláusulas sobre la sumisión de controversias a la Corte.

213 Pueden verse en el curso de Villán Duran citado, págs. 217 a 221.

214 Ya hemos hecho referencia a la dificultad existente dentro de la Organización de la Unidad Africana, para la adopción de un tribunal regional de derechos humanos similar a los que existen en Europa y América. No obstante, las jurisdicciones internacionales ganan camino progresivamente, en una tendencia que terminará consagrándoles. Las disputas jurídicas que se vienen en la materia, tendrán que ver con la imparcialidad y efectividad del funcionamiento de dichas instituciones.

215 Conf. Art. 19 del Convenio Europeo, en Conseil de l'Europe: «Droits de l'Homme ...», Op. Cit., pág. 174.

216 Conf. Maskin, Héctor: «El Sistema Europeo de Derechos Humanos», pág. 20. Ed. Eudeba, Buenos Aires, Argentina, 1987.

217 El Protocolo IX Anexo al Convenio Europeo fue adoptado en noviembre de 1990 y entró en vigor en octubre de 1994.

218 Para un estudio del protocolo 9 véase Jimena Quesada, Luis and Salvioli, Fabián: «The individual, Human Rights and International Instruments: Focus on the Council of Europe». En The ELSA Law Review, N 2, 1994. Ed. DJOF Publishing; págs. 109 a 128; Copenhagen, Denmark, 1994.

219 Flauss, J. F.: «Le droit de recours individuel devant la Cour Européene des Droits de l'Homme», en: "Annuaire Francais de Droit Intenational" XXXVI, pág. 507, París, France, 1990.

220 Conf. Castro-Rial Garrone, Fanny: «El Sistema Europeo de Derechos Humanos ...»; Op. Cit. pág. 53.

221 Conf. Sánchez Legido, Angel: «La reforma del mecanismo de control ...»; Op. Cit. pág. 287.

222 Puede verse un análisis de la jurisprudencia europea en Berger, Vincent: «Jurisprudence de la Cour Européenne des Droits de L'Homme», 3 Edition, Ed. Sirey, Paris, France, 1991.

223 Conf. Mathieu, Jean Luc: «La défense internationale des Droits de 1' Homme», pág. 41; en: "¿Que sais je?" N 2733; Ed. Presses Universitaires de France, Paris, France, 1993.

224 Conf. Escobar Hernández, Concepción: «Algunas consideraciones críticas sobre el funcionamiento ...» Op. Cit., pág. 49.

225 Resolución 1503 (XLVIII) del Consejo Económico y Social de la Organización de las Naciones Unidas (ECOSOC), en: Juste Ruiz, José: «Derecho Internacional Público, Textos Básicos», pág. 213 y ss., Valencia, España, 1991. 


\section{Ibídem.}

227 Art. 40 de la Carta Arabe de Derechos Humanos, en: Al Midani, Mohamed A.: «Charte Arabe ...» Op. Cit., en: "Revue Universelle ...", Op. Cit. pág. 214.

228 Art. 31 de la Carta Africana de Derechos Humanos y de los Pueblos, en: Conseil de l'Europe: «Droits de l'Homme ...» Op. Cit. pág. 364.

229 Arts. 19 a 23 págs. del Convenio Europeo para la Salvaguarda y la Protección de los Derechos Humanos y las Libertades Fundamentales, en: Conseil de l'Europe: «Droits de l'Homme ...» Op. Cit. págs. 173 a 177.

230 Ver Estatuto de la Comisión Interamericana, arts. 2 y 3; en: Organización de los Estados Americanos: «Documentos básicos ...» Op. Cit. pág. 77.

231 Ya hemos hecho referencia a los avances en la materia, que ha experimentado la Organización de las Naciones Unidas. Aún así, sigue siendo imprescindible la voluntad política de los gobiernos, para comprender que, lejos de representar una amenaza para ellos, el establecimiento de mecanismos internacionales de derechos humanos, que funcionen efectiva e imparcialmente, junto a la inserción de la temática de derechos humanos en ámbitos educativos formales e informales, colaborará en un mejor disfrute para las sociedades, de los derechos y libertades fundamentales de la persona.

232 Conf. Art. 38 del Convenio Europeo para la Salvaguarda y la Protección de los Derechos Humanos y las Libertades Fundamentales, en Conseil de l'Europe: «Droits de l'Homme ...» Op. Cit. pág. 181.

233 Conf. Estatuto de la Corte Interamericana, art. 4, en: Organización de los Estados Americanos: «Documentos básicos ...» Op. Cit. pág. 109.

234 Para un estudio comparativo exhaustivo de la cuestión puede consultarse Gros Espiell, Héctor: «... La Convención Americana y la Convención Europea ...» Op. Cit. págs. 161 a 193.

$235 \mathrm{El}$ otro órgano específico de derechos humanos del sistema interamericano es, como hemos visto en el Capítulo anterior, la Comisión Interamericana de Derechos Humanos, que ha sido creada en 1959. A partir de la entrada en vigencia del Protocolo de Buenos Aires, modificatorio de la Carta de la Organización de los Estados Americanos, la Comisión Interamericana se ha convertido en un órgano principal de la entidad, con funciones más amplias que aquellas que le fueron otorgadas cuando la V Reunión de Consulta de Ministros de Relaciones Exteriores, le dio nacimiento.

236 Conf. Dunshee de Abranches, C. A.: «La Corte Interamericana de Derechos Humanos», en: "La Convención Americana sobre Derechos Humanos" Op. Cit. págs. 92/3.

237 Convención Americana sobre Derechos Humanos: art. 33 y arts. 52 a 69, en: Organización de los Estados Americanos: «Documentos básicos ...» Op. Cit. págs. 35 y 41 a 44.

238 Ibídem: arts. 52 a 54.

239 Conf. Medina, Cecilia: «El Sistema Interamericano de promoción y protección de los Derechos Humanos», en: "Derecho Internacional de los Derechos Humanos, manual de enseñanza", pág. 165; Ed. Instituto Holandés de Derechos Humanos, Amsterdam, Holanda, 1990.

240 Convención Americana sobre Derechos Humanos: art. 55, en: Organización de los Estados Americanos: «Documentos básicos ...» Op. Cit. págs. 41/42. 
241 Puede verse al respecto Nieto Navia, Rafael: «La Corte Interamericana de Derechos Humanos», en: "Estudios Básicos sobre Derechos Humanos I", págs. 260/1, Ed. Instituto Interamericano de Derechos Humanos, San José de Costa Rica, 1994.

242 La función consultiva está regulada por el artículo 64 de la Convención Americana sobre Derechos Humanos, y en los artículos 51 a 56 del Estatuto de la Corte Interamericana de Derechos Humanos.

243 Ventura, Manuel y Zovatto, Daniel: «La función consultiva de la Corte Interamericana de Derechos Humanos»; pág. 34. Instituto Interamericano de Derechos Humanos; Ed. Civitas, San José de Costa Rica, 1989.

244 Conf. Carta de las Naciones Unidas, art. 96; en: Zavalía, Víctor: «Recopilación de instrumentos...», Op. Cit. pág. 38.

245 Dentro del sistema instalado en el Consejo de Europa, la función consultiva no se encuentaba prevista en el tratado original, que había sido aprobado en Roma por los Estados Miembros en 1950. Esta laguna, ha sido sustituida por la adopción del Protocolo N 2 Anexo al Convenio Europeo de Derechos Humanos, adoptado en Estrasburgo el 6 de mayo de 1963, y que entró en vigor el 21 de setiembre de 1970. Su texto puede observarse en Conseil de l'Europe: «Droits de l'Homme ...» Op. Cit., págs. 190 a 192. Igualmente, tal como lo hemos destacado, la función consultiva del Tribunal Europeo es, en la práctica, inexistente.

246 Conf. Art. Primero, en Ibídem, pág. 190.

247 Ibídem, pág. 190.

248 Un estudio crítico, se pregunta provocativamente si es necesario el mantenimiento de la jurisdicción consultiva del Tribunal Europeo de Derechos Humanos. Ver al respecto Drzemczewski, Andrew: «Advisory Jurisdiction of the European Human rights Court: A Procedure Worth Retaining?»; en: "El mundo moderno de los derechos humanos. Ensayos en honor de Thomas Buergenthal" págs.493 a 516. Ed. Instituto Interamericano de Derechos Humanos, San José de Costa Rica, 1996.

249 Conf. Santoscoy-Noro, Berta: «Le systéme interaméricain de protection des droits de l'Homme», en: Institut International des Droits De l'Homme, "Recueil des Cours: Collection of Lectures, Textes et Sommaires" 1996; Op. Cit. pág. 216 (traducción no oficial).

250 Conf. Buergenthal, Thomas; Grossman, Claudio; y Nikken, Pedro: «Manual Internacional de Derechos Humanos», Op. Cit. pág. 112.

251 Conf. Salvioli, Fabián: «El sistema interamericano de protección de los derechos humanos», en: Institut International des Droits De l'Homme "XXVIème Session d'Enseignement: Recueil des Cours 1995 ..."; Op. Cit. págs. 250 y ss.

252 Convención Americana sobre Derechos Humanos: arts. 61 y 63, en: Organización de los Estados Americanos: «Documentos básicos ...» Op. Cit. págs. 42 y 43.

253 Conf. Fix Zamudio, Héctor: «La protección judicial de los derechos humanos en Latinoamérica y en el Sistema Interamericano»; en: "Revista N 8", pág. 62. Ed. Instituto Interamericano de Derechos Humanos, San José de Costa Rica, 1988. 108.

254 Conf. Hitters, Juan C.: «Derecho Internacional de los Derechos Humanos», Op. Cit. Tomo I, pág.

255 Convención Americana sobre Derechos Humanos: art. 62; en: Organización de los Estados Americanos: «Documentos básicos...»; Op. Cit. págs. 42/43. 
256 Los diecisiete Estados que han realizado la declaración de aceptación de la competencia contenciosa de la Corte Interamericana son: Argentina, Bolivia, Colombia, Costa Rica, Chile, Ecuador, El Salvador, Guatemala, Nicaragua, Honduras, Panamá, Paraguay, Perú, Suriname, Trinidad y Tobago, Uruguay y Venezuela; conforme Organización de los Estados Americanos: «Documentos básicos ...» Op. Cit., pág. 49.

257 Conf. Gros Espiell, Héctor: «El procedimiento contencioso ante la Corte Interamericana de Derechos Humanos», en: "Estudios básicos de derechos humanos II", pág. 158; Ed. Civitas, Instituto Interamericano de Derechos Humanos, San José de Costa Rica, 1988.

258 Conf. Carrillo Salcedo, Juan A. y Salado Osuna, Ana: «El mecanismo de garantía instituido en la Convención Americana sobre Derechos Humanos», en: "Derecho Internacional Público II", pág. 30, Curso 1995/6, Ed. Facultad de Derecho, Universidad de Sevilla, España, 1996.

259 para un análisis del Protocolo IX puede verse Jimena Quesada, Luis and Salvioli, Fabián: «The individual, Human Rights and International Instruments ...»; Op. Cit. págs. 109 a 128.

260 Conf. Salvioli, Fabián: «Los desafíos del Sistema Interamericano de protección de los Derechos Humanos»; en: "Estudios Básicos de Derechos Humanos V"; Op. Cit. págs. 254/5.

261 Conf. Cançado Trindade, Antônio: «El Sistema Interamericano de protección de los Derechos Humanos (1948 - 1995): evolución, estado actual y perspectivas»; en: "Derecho Internacional y Derechos Humanos"; pág. 82; libro conmemorativo de la XXIV Sesión Exterior de la Academia de Derecho Internacional de La Haya; Ed. IIDH; San José de Costa Rica, 1996.

262 Conf. Méndez, Juan: «La participación de la víctima ante la Corte Interamericana de Derechos Humanos», en: "La Corte y el Sistema Interamericanos ..." Op. Cit. pág. 332.

263 Corte Interamericana de Derechos Humanos: CDH - CP6/96, pág. 5. Ed. Secretaría de la Corte, San José de Costa Rica; 8 de octubre de 1996.

264 Convención Americana sobre Derechos Humanos: art. 63 inc 1. en: Organización de los Estados Americanos: «Documentos básicos ... «; Op. Cit. pág. 43.

265 Corte Interamericana de Derechos Humanos: caso «Velásquez Rodríguez», Indemnización Compensatoria, sentencia de 21 de julio de 1989, Serie C N 7, Ed. Secretaría de la Corte, San José de Costa Rica, 1990, pág. 21; y caso «Godínez Cruz», Indemnización Compensatoria, sentencia de 21 de julio de 1989, Serie C N 8, pág. 19 Ed. Secretaría de la Corte, San José de Costa Rica, 1990.

266 Véase al respecto Salvioli, Fabián: «Algunas reflexiones sobre la indemnización en las sentencias de la Corte Interamericana de Derechos Humanos», en: Instituto Interamericano de Derechos Humanos "Estudios Básicos de Derechos Humanos III", Op. Cit. págs. 145 a 164.

267 Hemos realizado un breve estudio sobre la evolución de las sentencias contenciosas de la Corte Interamericana. Ver al respecto Salvioli, Fabián: «La justicia como garante de la dignidad humana...»; Op. Cit.; págs. 31 a 34 .

268 Convención Americana sobre Derechos Humanos: art. 68.2., en: Organización de los Estados Americanos: «Documentos básicos ...»; Op. Cit. pág. 44.

269 Conf. Rodríguez Rescia, Víctor: «Eficacia jurídica de la jurisprudencia de la Corte Interamericana de Derechos Humanos», en: "La Corte y el Sistema Interamericanos...", Op. Cit. pág. 462.

270 Convención Americana sobre Derechos Humanos: art. 63.2; en: Organización de los Estados Americanos: «Documentos básicos ...» Op. Cit.; pág. 43. 
271 Respecto a este requisito, es interesante una opinión doctrinal que sostiene que la Comisión Interamericana de Derechos Humanos, podría formular una solicitud de medidas provisionales respecto de un Estado que aún no haya aceptado la competencia contenciosa de la Corte; ver al respecto Quintana, Juan José: «Los procedimientos incidentales ante la Corte Interamericana de Derechos Humanos», en: "Revista N 21", págs. 121 a 148. Ed. Instituto Interamericano de Derechos Humanos, San José de Costa Rica, 1995.

272 Un análisis completo de la temática referente a las medidas provisionales puede observarse en Pasqualucci, Jo M.: «Medidas provisionales en la Corte Interamericana de Derechos Humanos: una comparación con la Corte Internacional de Justicia y la Corte Europea de Derechos Humanos», en Revista N 19 del Instituto Interamericano de Derechos Humanos; San José de Costa Rica, 1994.

273 Conf. Salvioli Fabián: «El sistema interamericano de protección de los derechos humanos», en: Institut International des Droits de l'Homme: "XXVIIème Session d'Enseignement: Recueil des Cours, 1996 ..."; Op. Cít. págs. 302/3.

274 Corte Interamericana de Derechos Humanos: Reglamento, art. 24: medidas provisionales.

275 El art. 64 de la Convención Americana sobre Derechos Humanos estipula en su primera parte: «...1. Los Estados miembros de la Organización podrán consultar a la Corte acerca de la interpretación de esta Convención o de otros tratados concernientes a la protección de los derechos humanos en los Estados Americanos. Asimismo, podrán consultarla, en lo que les compete, los órganos enumerados en el capítulo X de la Carta de la Organización de los Estados Americanos, reformada por el Protocolo de Buenos Aires ...»; en: Organización de los Estados Americanos: «Documentos básicos ...» Op. Cit.; pág. 43.

276 Corte Interamericana de Derechos Humanos: «Otros tratados: objeto de la función consultiva de la Corte». Op. Cit. Párr. 52, pág. 28.

$277 \mathrm{El}$ art. 74 de la Convención Americana, en la estricta parte objeto de la consulta, establece: «... 2. ... Tan pronto como once Estados hayan depositado sus respectivos instrumentos de ratificación o de adhesión, la Convención entrará en vigor. Respecto a todo otro Estado que la ratifique o adhiera a ella ulteriormente, la Convención entrará en vigor en la fecha del depósito de su instrumento de ratificación o adhesión ...»; en Organización de los Estados Americanos: «Documentos básicos ...; Op. Cit. pág. 45.

278 Corte Interamericana de Derechos Humanos: «El efecto de las reservas sobre la entrada en vigencia de la Convención Americana de Derechos humanos (arts. 74 y 75)». Op. Cit. Ed. Secretaría de la Corte, Serie A N 2.

279 El art. 4 de la Convención Americana determina, en lo que respecta a la consulta: «... Derecho a la Vida. 1. Toda persona tiene derecho a que se respete su vida. Esta derecho estará protegido por la ley y, en general, a partir del momento de la concepción. Nadie puede ser privado de la vida arbitrariamente. 2. En los paises que no han abolido la pena de muerte, ésta podrá imponerse por los delitos más graves, en cumplimiento de sentencia ejecutoriada de tribunal competente y de conformidad con una ley que establezca tal pena, dictada con anterioridad a la comisión del delito. Tampoco se extenderá su aplicación a delitos a los cuales no se la aplique actualmente. 3. No se restablecerá la pena de muerte en los Estados que la han abolido. 4. en ningún caso se puede aplicar la pena de muerte por delitos políticos ni comunes conexos con los políticos. ...»; en Organización de los Estados Americanos: «Documentos básicos ...», Op. Cit. pág. 26.

280 Corte Interamericana de Derechos Humanos: «Restricciones a la pena de muerte (arts. 4.2 y 4.4, Convención Americana sobre Derechos Humanos)». Opinión Consultiva OC-3/83 del 8 de setiembre de 1983. Serie A N 3. Secretaría de la Corte Interamericana, San José de Costa Rica, 1983.

$281 \mathrm{El}$ art. 64 de la Convención Americana, en la parte objeto de la consulta, dispone: «... 2. La Corte, a solicitud de un Estado miembro de la Organización, podrá darle opiniones acerca de la compatibilidad entre cualquiera de sus leyes internas y los mencionados instrumentos internacionales ...» (se refiere a los mencionados en el parágrafo 1 del art. 64; en Organización de los Estados Americanos: «Documentos básicos ...»; Op. Cit.; pág. 43. 
282 Corte Interamericana de Derechos Humanos: «Propuesta de modificación a la constitución política de Costa Rica relacionada con la naturalización». Opinión Consultiva OC-4/84 del 19 de enero de 1984. Serie A N 4. Ed. Secretaría de la Corte, San José de Costa Rica, 1984.

283 Corte Interamericana de Derechos Humanos: «La Colegiación Obligatoria de Periodistas (arts. 13 y 29 Convención Americana sobre Derechos Humanos)». Opinión Consultiva OC-5/85 del 13 de noviembre de 1985. Serie A N 5. Ed. Secretaría de la Corte; San José de Costa Rica, 1985.

284 El art. 30 de la Convención Americana sobre derechos humanos prescribe: «...Alcance de las restricciones. Las restricciones permitidas, de acuerdo con esta Convención, al goce y ejercicio de los derechos y libertades reconocidas en la misma, no pueden ser aplicadas sino conforme a leyes que se dictaren por razones de interés general y con el propósito para el cual han sido establecidas; en: Organización de los Estados Americanos: «Documentos básicos...», Op. Cit., pág. 35.

285 Corte Interamericana de Derechos Humanos: «La expresión Leyes en el artículo 30 de la Convención Americana sobre Derechos Humanos». Opinión Consultiva OC-6/86 del 9 de mayo de 1986. Serie A N 6. Ed. Secretaría de la Corte, San José de Costa Rica, 1986.

286 Corte Interamericana de Derechos Humanos: «Exigibilidad del derecho de rectificación o respuesta (Arts. 14.1, 1.1 y 2, Convención Americana sobre Derechos Humanos)». Opinión Consultiva OC-7/86 del 29 de agosto de 1986. Serie A N 7. Ed. Secretaría de la Corte, San José de Costa Rica, 1986.

287 El problema jurídico, radica en que el art. 27 inc. 2 de la Convención Americana sobre Derechos Humanos, dispone que no se autoriza la suspensión de ciertos derechos (nombrándolos expresamente), ni de «... las garantías judiciales indispensables para la protección de tales derechos ...», sin decir cuales son esas garantías. La Corte debía, entonces, interpretar si los derechos a la protección judicial y el hábeas corpus debían o no considerarse insuspendibles, conforme a la letra del Pacto de San José de Costa Rica.

288 Corte Interamericana de Derechos Humanos: «El Hábeas Corpus bajo suspensión de garantías (Arts. 27.2, 25.1 y 7.6, Convención Americana sobre Derechos Humanos)». Opinión Consultiva OC-8/87 del 30 de enero de 1987. Serie A N 8. Ed. Secretaría de la Corte, San José de Costa Rica, 1987.

289 Corte Interamericana de Derechos Humanos: «Garantías judiciales en estado de emergencia (arts. 27.2, 25 y 8, Convención Americana sobre Derechos Humanos)». Opinión Consultiva OC-9/87 del 6 de octubre de 1987. Serie A N 9. Ed.Secretaría de la Corte, San José de Costa Rica, 1987.

290 Al igual que en el caso de la Opinión Consultiva N 4, la tarea de la Corte se iba a centrar en la interpretación del alcance de la propia función consultiva. El art. 64 de la Convención Americana, en la parte objeto de la consulta, dispone: «... 2. La Corte, a solicitud de un Estado miembro de la Organización, podrá darle opiniones acerca de la compatibilidad entre cualquiera de sus leyes internas y los mencionados instrumentos internacionales ...» (se refiere a los mencionados en el parágrafo 1 del art. 64; en Organización de los Estados Americanos: «Documentos básicos ...; Op. Cit.; pág. 43.

291 Corte Interamericana de Derechos Humanos: «Interpretación de la Declaración de los Derechos y Deberes del Hombre en el marco del artículo 64 de la Convención Americana sobre Derechos Humanos». Opinión Consultiva OC-10/89 del 14 de julio de 1989. Serie A N 10. Ed. Secretaría de la Corte, San José de Costa Rica, 1989.

292 Ver Capítulo II, II. «Las características de la protección internacional», punto 2.- «La subsidiariedad».

293 Corte Interamericana de Derechos Humanos: «Excepciones al agotamiento de los recursos internos (Art. 46.1, 46.2.a y 46.2.b Convención Americana sobre Derechos Humanos)». Opinión Consultiva OC11/90 del 10 de agosto de 1990. Serie A N 11. Ed. Secretaría de la Corte, San José de Costa Rica, 1990. 
294 Corte Interamericana de Derechos Humanos: «Compatibilidad de un proyecto de ley con el artículo 8.2.h de la Convención Americana sobre Derechos Humanos». Opinión Consultiva OC-12/91 del 6 de diciembre de 1991. Serie A N 12. Ed. Secretaría de la Corte, San José de Costa Rica, 1991.

295 Corte Interamericana de Derechos Humanos: «Ciertas atribuciones de la Comisión Interamericana de Derechos Humanos (artículos 41, 42, 46, 47, 50 y 51 de la Convención Americana sobre Derechos Humanos)». Opinión Consultiva OC-13/93 del 16 de julio de 1993. Serie A N 13. Ed. Secretaría de la Corte, San José de Costa Rica, 1993.

296 Corte Interamericana de Derechos Humanos: «Responsabilidad internacional por expedición y aplicación de leyes violatorias de la Convención Americana sobre Derechos Humanos (arts. 1 y 2 de la Convención Americana sobre Derechos Humanos)». Opinión Consultiva OC-14/94 del 9 de diciembre de 1994. Serie A N 14. Ed. Secretaría de la Corte, San José de Costa Rica, 1994.

297 Corte Interamericana de Derechos Humanos: «Asunto Viviana Gallardo y Otras», Decisión del 13 de noviembre de 1981, N G 101/81, Serie A. Edit. Secretaría de la Corte, San José de Costa Rica, 1982.

$298 \mathrm{Al}$ haber sido el primer caso contencioso resuelto sobre el fondo, interesantes temas de procedimiento han sido ventilados en el asunto; véase al respecto Hitters, Juan Carlos: «La Corte Interamericana y la condena al gobierno de Honduras, aspectos procesales»; en "Revista Uruguaya de Derecho Procesal" N 3, Montevideo, Uruguay, 1988.

299 Corte Interamericana de Derechos Humanos: «Caso Velásquez Rodríguez». Excepciones Preliminares. Serie C, N 1. Sentencia del 26 de junio de 1987. Ed. Secretaría de la Corte, San José de Costa Rica, 1988.

300 Corte Interamericana de Derechos Humanos: «Caso Velásquez Rodríguez». Serie C, Resoluciones y Sentencias; N 4. Sentencia del 29 de julio de 1988. Ed. Secretaría de la Corte, San José de Costa Rica, 1988.

301 Corte Interamericana de Derechos Humanos: «Caso Velásquez Rodríguez: Indemnización Compensatoria (Art. 63.1 Convención Americana sobre Derechos Humanos)». Serie C, Resoluciones y Sentencias; N 7. Sentencia del 21 de julio de 1989. Ed. Secretaría de la Corte, San José de Costa Rica, 1990.

302 Corte Interamericana de Derechos Humanos: «Caso Godínez Cruz». Excepciones Preliminares. Serie C, N 3. Sentencia del 26 de junio de 1987. Ed. Secretaría de la Corte, San José de Costa Rica, 1988.

303 Corte Interamericana de Derechos Humanos: «Caso Godínez Cruz». Serie C, Resoluciones y Sentencias; N 5. Sentencia del 21 de julio de 1989; Ed. Secretaría de la Corte, San José de Costa Rica, 1990.

304 Corte Interamericana de Derechos Humanos: «Caso Godínez Cruz»: Indemnización Compensatoria (Art. 63.1 Convención Americana sobre Derechos Humanos). Serie C, Resoluciones y Sentencias; N 8. Sentencia del 21 de julio de 1989. Ed. Secretaría de la Corte, San José de Costa Rica, 1990.

305 Corte Interamericana de Derechos Humanos: «Caso Fairén Garbi y Solís Corrales»; Serie C, Resoluciones y Sentencias; N 6. Sentencia del 15 de marzo de 1989; Ed. Secretaría de la Corte, San José de Costa Rica, 1989.

306 Corte Interamericana de Derechos Humanos: «Caso Neira Alegría y Otros». Excepciones Preliminares. Serie C, N 13. Sentencia del 11 de diciembre de 1991. Ed. Secretaría de la Corte, San José de Costa Rica, 1991.

307 Corte Interamericana de Derechos Humanos: «Caso Neira Alegría y Otros»: sentencia del 19 de enero de 1995; en: Corte Interamericana de Derechos Humanos: "Informe Anual 1995", págs. 41 a 62. Ed. Secretaría General de la Organización de los Estados Americanos, Washington D.C., Estados Unidos, 1996. 
308 Corte Interamericana de Derechos Humanos: «Caso Neira Alegría y otros». Sentencia sobre reparaciones del 19 de setiembre de 1996; en: Corte Interamericana de Derechos Humanos: "Informe Anual 1996", págs. 179 a 194. Ed. Secretaría de la Corte, San José de Costa Rica; 1997.

309 Corte Interamericana de Derechos Humanos: «Caso Cayara»; Excepciones Preliminares. Serie C, Resoluciones y Sentencias; N 14. Sentencia del 3 de febrero de 1993; Ed. Secretaría de la Corte, San José de Costa Rica, 1994.

310 Corte Interamericana de Derechos Humanos: «Caso Gangaram Panday». Excepciones Preliminares. Serie C, N 12. Sentencia del 4 de diciembre de 1991. Ed. Secretaría de la Corte, San José de Costa Rica, 1991.

311 Corte Interamericana de Derechos Humanos: «Caso Gangaram Panday». Sentencia del 21 de enero de 1994; en: Corte Interamericana de Derechos Humanos: "Informe Anual 1994"; págs. 21 a 42. Ed. Secretaría General de la Organización de los Estados Americanos, Washington D.C., Estados Unidos, 1995.

312 Corte Interamericana de Derechos Humanos: «Caso Aloeboetoe y otros»; Serie C, Resoluciones y Sentencias; N 11. Sentencia del 4 de diciembre de 1991; Ed. Secretaría de la Corte, San José de Costa Rica, 1994.

313 Corte Interamericana de Derechos Humanos: «Caso Aloeboetoe y otros», Reparaciones (Art. 63.1 Convención Americana sobre Derechos Humanos). Serie C, Resoluciones y Sentencias; N 15. Sentencia de 10 de setiembre de 1993; Ed. Secretaría de la Corte, San José de Costa Rica, 1994.

314 Corte Interamericana de Derechos Humanos: «Caso Caballero Delgado y Santana». Excepciones Preliminares. Serie C, N 17. Sentencia del 21 de enero de 1994. Secretaría de la Corte, San José de Costa Rica, 1994.

315 Corte Interamericana de Derechos Humanos: «Caso Caballero Delgado y Santana». Sentencia del 8 de diciembre de 1995; en: Corte Interamericana de Derechos Humanos: "Informe Anual 1995"; págs. 135 a 163. Ed. Secretaría General de la Organización de los Estados Americanos, Washington D.C., Estados Unidos, 1996.

316 Corte Interamericana de Derechos Humanos: «Caso Maqueda». Sentencia del 18 de enero de 1995; en: Corte Interamericana de Derechos Humanos: "Informe Anual 1995"; págs. 31 a 37. Ed. Secretaría General de la Organización de los Estados Americanos, Washington D.C., Estados Unidos, 1996.

317 Corte Interamericana de Derechos Humanos: «Caso El Amparo». Sentencia del 18 de enero de 1995; en: Corte Interamericana de Derechos Humanos: "Informe Anual 1995"; págs. 23 a 29. Ed. Secretaría General de la Organización de los Estados Americanos, Washington D.C., Estados Unidos, 1996.

318 Corte Interamericana de Derechos Humanos: «Caso El Amparo». Sentencia sobre reparaciones del 14 de setiembre de 1996; en: Corte Interamericana de Derechos Humanos: "Informe Anual 1996", págs. 159 a 178 Ed. Secretaría de la Corte, San José de Costa Rica; 1997.

319 Corte Interamericana de Derechos Humanos: «Caso Garrido y Baigorria». Sentencia del 2 de febrero de 1996; en: Corte Interamericana de Derechos Humanos: "Informe Anual 1996", págs. 75 a 82 Ed. Secretaría de la Corte, San José de Costa Rica; 1997.

320 Corte Interamericana de Derechos Humanos: «Caso Genie Lacayo»; Excepciones Preliminares, en: Corte Interamericana de Derechos Humanos: "Informe Anual 1995", págs. 63 a 72 y 79 a 92. OEA, Ser.L./V/III.33; Ed. Secretaría General de la OEA, Washington D.C., Estados Unidos; 22 de enero de 1996. 
321 Corte Interamericana de Derechos Humanos: «Caso Paniagua Morales y Otros»; Excepciones Preliminares; Sentencia del 25 de enero de 1996, en Corte Interamericana de Derechos Humanos: "Informe Anual 1996", págs. 29 a 42. Ed. Secretaría de la Corte, San José de Costa Rica, 1997.

322 Corte Interamericana de Derechos Humanos: «Caso Castillo Páez»; Excepciones Preliminares; Sentencia del 30 de enero de 1996; en: Corte Interamericana de Derechos Humanos: "Informe Anual 1996", págs. 43 a 58. Ed. Secretaría de la Corte, San José de Costa Rica; 1997.

323 Corte Interamericana de Derechos Humanos: «Caso Loayza Tamayo»; Excepciones Preliminares; Sentencia del 31 de enero de 1996; en: Corte Interamericana de Derechos Humanos: "Informe Anual 1996", págs. 59 a 74. Ed. Secretaría de la Corte, San José de Costa Rica; 1997.

324 Corte Interamericana de Derechos Humanos: «Caso Blake»: Excepciones Preliminares. Sentencia del 2 de julio de 1996, en: Corte Interamericana de Derechos Humanos: "Informe Anual 1996", págs. 95 a 110. Ed. Secretaría de la Corte, San José de Costa Rica, 1997.

325 Corte Interamericana de Derechos Humanos: «Caso Suárez Rosero»; en: Corte Interamericana de Derechos Humanos: "CDH - CP2/96", pág. 3. Ed. Secretaría de la Corte, San José de Costa Rica, 3 de febrero de 1996.

326 Corte Interamericana de Derechos Humanos: «Caso Benavídes Cevallos»; en: Corte Interamericana de Derechos Humanos, "CDH - CP4/96", pág. 3. Ed. Secretaría de la Corte, San José de Costa Rica, 4 de julio de 1996.

327 Corte Interamericana de Derechos Humanos: «Caso Cantoral Benavides» en: Corte Interamericana de Derechos Humanos: "CDH - CP6/96", pág. 3. Ed. Secretaría de la Corte, San José de Costa Rica; 8 de octubre de 1996.

328 Corte Interamericana de Derechos Humanos: «Caso Durand y Ugarte» en: Corte Interamericana de Derechos Humanos: "CDH - CP6/96", pág. 4. Ed. Secretaría de la Corte, San José de Costa Rica; 8 de octubre de 1996.

329 Corte Interamericana de Derechos Humanos: «Caso Bámaca Velásquez»en: Corte Interamericana de Derechos Humanos: "CDH - CP6/96", pág. 4. Ed. Secretaría de la Corte, San José de Costa Rica; 8 de octubre de 1996.

330 Conf. Buergenthal, Thomas; Grossman, Claudio; y Nikken, Pedro: «Manual internacional de derechos humanos», Op. Cit. pág. 112.

331 Conf. Travieso, Juan Antonio: «La Corte Interamericana de Derechos Humanos»; pág. 15; Ed. Abeledo Perrot, Buenos Aires, Argentina, 1996.

332 Conf. Barberis, Julio: «Formación del Derecho Internacional» págs. 233 a 235, principalmente. Ed. Abaco de Rodolfo De Palma, Buenos Aires, Argentina, 1994.

333 Conf. Mariño Menéndez, Fernando: «Derecho Internacional Público (parte general)»; Op. Cit. pág. 353.

334 Conf. Jiménez de Aréchaga, Eduardo: «Principios generales que rigen la conducta de los Estados», Cap. IV, en: "El Derecho Internacional Contemporáneo", Op. Cit. pág. 106.

335 Conf. Naciones Unidas: Asamblea General: Resolución 2625 (XXV); en Zavalía, Víctor: «Recopilación ...» Op. Cit. págs. 84 a 96. 
336 Conf. art. 38 parágrafo 3 del Estatuto de la Corte Internacional de Justicia; en Zavalía, Víctor: «Recopilación ...» Op. Cit. pág. 52.

337 Conf. Pastor Ridruejo, José: «Curso de Derecho Internacional Público ...» Op. Cit., pág. 87.

338 Conf. Kelsen, Hans: «Principios de Derecho Internacional Público», pág. 262; Ed. El Ateneo, Buenos Aires, Argentina, 1965.

339 Conf. Puig, Juan Carlos: «Derecho de la Comunidad Internacional»; Op. Cit. pág. 186 y 187.

340 Conf. Mariño Menéndez, Fernando: «Derecho Internacional Público (parte general)»; Op. Cit. pág. 350.

341 Conf. Sorensen, Max: «Manual de Derecho Internacional Público»; Op. Cit. pág. 172.

342 Conf. Carrillo Salcedo, Juan: «Soberanía de los Estados ...»; Op. Cit. pág. 135.

343 Conf. Bidart Campos, Germán y Herrendorf, Daniel: «Principios de derechos humanos y garantías» pág. 123; Ed. Ediar; Buenos Aires, Argentina, 1991.

344 Ya nos hemos referido a las coincidencias, al tratar las competencias consultiva y contenciosa de la Corte Interamericana de Derechos Humanos; ver supra Capítulo IV.

345 Conf. Convención Americana de Derechos Humanos: art. 62; en Organización de los Estados Americanos: «Documentos básicos ...» Op. Cit. págs. 42/43.

346 Conf. Hitters, Juan C.: «Derecho Internacional de los Derechos Humanos». Tomo II: «Sistema Interamericano»; pág. 445; Ed. Ediar, Buenos Aires, Argentina, 1993.

347 Ver supra Capítulo IV: La Corte Interamericana de Derechos Humanos. Competencias y asuntos tratados. Particularmente el punto II.1.- La Competencia Consultiva, y III.1.- Las opiniones consultivas emitidas por la Corte Interamericana. Sobre la amplitud de la función consultiva de la Corte Interamericana de Derechos Humanos según la jurisprudencia de la Corte, remitimos al Capítulo VIII del presente trabajo, punto II.1.

348 Conf. Convención Americana de Derechos Humanos: art. 64; en Organización de los Estados Americanos: «Documentos básicos ...» Op. Cit. pág. 43.

349 Ver Capítulo VI, Punto II.1.- «Los métodos de interpretación que utiliza la Corte Interamericana, son los mismos que posee el Derecho Internacional general».

350 Corte Interamericana de Derechos Humanos: «Caso Aloeboetoe y otros» Reparaciones (Art. 63.1 Convención Americana sobre Derechos Humanos). Serie C, Resoluciones y Sentencias; N 15, párr. 61., Op. Cit. pág. 25.

351 Conf. Espinal Arias, Rigoberto: «Competencia y funciones de la Corte Interamericana de Derechos Humanos, en: "La Corte y el Sistema Interamericanos de Derechos Humanos", Op. Cit. pág. 120.

352 Hemos dedicado todo el Capítulo II, a señalar y poner de manifiesto esta relación.

353 Establecidas en las normas de interpretación de la Convención de Viena sobre Derecho de los Tratados, ver Convención de Viena sobre Derecho de los Tratados: (Naciones Unidas, 1969), Parte III, Sección 3: interpretación de los Tratados, arts. 31 a 33): en Zavalía, Víctor: «Recopilación ...» Op. Cit. págs. 770 a 772. 
354 Corte Interamericana de Derechos Humanos: «Caso Velásquez Rodríguez»: Indemnización Compensatoria (Art. 63.1 Convención Americana sobre Derechos Humanos); párr. 38, Op. Cit. págs. 23/24; y «Caso Godínez Cruz»: Indemnización Compensatoria (Art. 63.1 Convención Americana sobre Derechos Humanos); párr. 36, Op. Cit. pág. 21.

355 Conforme al ya citado libro de Nikken, Pedro: «La protección Internacional de los derechos humanos: su desarrollo progresivo»; Ed. Instituto Interamericano de Derechos Humanos / Cívitas, Madrid, España, 1987.

356 Remitimos en este punto a los temas desarrollados en el Capítulo II del presente trabajo; en particular su punto II.2.- «Las características de la protección internacional».

357 Conf. Buergenthal, Thomas; Grossman, Claudio; y Nikken, Pedro: «Manual internacional de derechos humanos ...», Op. Cit. pág. 171.

358 En este sentido, la Asamblea General de las Naciones Unidas adoptó la Resolución N 1514 de 1960, llamada « Declaración sobre la concesión de la independencia a los paises y pueblos coloniales»; en: Zavalía, Héctor: "Recopilación ..." Op. Cit., págs. 77 a 79.

359 Asamblea General: (Naciones Unidas) Resolución 1514 (XV), primer párrafo, en Ibídem, pág. 77.

360 Ibídem, pág. 78.

361 Conf. Villán Duran, Carlos: «Curso de Derecho Internacional de los Derechos Humanos», Op. Cit. pág. 39.

362 Conf. Hitters, Juan C.: «Derecho Internacional de los Derechos Humanos», Tomo I, Op. Cit. pág. 191.

363 Desarrollamos el Postulado al respecto infra, Capítulo VII; Punto II.5.

364 Hemos hecho mención al respecto en el Capítulo II, y desarrollamos la jurisprudencia pertinente de la Corte Interamericana de Derechos Humanos en el Capítulo VII, punto II.1.

365 También nos hemos referido a esta cuestión en el Capítulo II, último punto, y en el Capítulo III, punto III.2, al tratar la protección extraconvencional de los derechos humanos. En cuanto a la jurisprudencia pertinente de la Corte Interamericana de Derechos Humanos sobre el punto, podemos encontrarla en el Capítulo VII, punto II.4.

366 El análisis de la jurisprudencia pertinente de la Corte Interamericana de Derechos Humanos sobre el principio «pro homine» se encuentra infra, en el Capítulo VII, punto II.2.

367 Todos ellos, y el desarrollo jurisprudencial que la Corte Interamericana de Derechos Humanos ha hecho de los mismos, se encuentran en el Capítulo VIII del presente trabajo.

368 Citamos como ejemplo el Postulado que trabajamos sobre los métodos de interpretación que aplica la Corte Interamericana, el cual ha sido objeto de análisis del Tribunal en varias opiniones consultivas y decisiones contenciosas; ver infra, Capítulo VI, Punto II.1.

369 Por ejemplo el principio de no discriminación, que ha sido tratado fundamentalmente en la Opinión Consultiva N 4 de la Corte Interamericana de Derechos Humanos; ver infra, el último punto del Capítulo VII. 
370 Ver Corte Interamericana de Derechos Humanos: «Caso Cayara»; Excepciones Preliminares. Serie C, Resoluciones y Sentencias; N 14. Sentencia del 3 de febrero de 1993; Ed. Secretaría de la Corte, San José de Costa Rica, 1994.

371 Ver Corte Interamericana de Derechos Humanos: «Caso Blake»: Excepciones Preliminares. Sentencia del 2 de julio de 1996, en: Corte Interamericana de Derechos Humanos, "CDH - CP4/96". Ed. Secretaría de la Corte, San José de Costa Rica, 4 de julio de 1996.

372 Veremos el llamado «principio de legalidad», en el análisis de varias resoluciones de la Corte (Ver el Capítulo siguiente), no obstante, se destaca lo señalado preferentemente en Corte Interamericana de Derechos Humanos: «La expresión Leyes en el artículo 30 de la Convención Americana sobre Derechos Humanos». Opinión Consultiva OC-6/86 del 9 de mayo de 1986. Serie A N 6. Secretaría de la Corte, San José de Costa Rica, 1986.

373 Conf. Convención Americana sobre Derechos Humanos: art. 1.1; en: Organización de los Estados Americanos: «Documentos básicos ...» Op. Cit. págs. 25/26.

374 Corte Interamericana de Derechos Humanos: «Caso Aloeboetoe y otros», Reparaciones (Art. 63.1 Convención Americana sobre Derechos Humanos); Op. Cit. párr. 61, pág. 25.

375 Convención de Viena sobre Derecho de los Tratados: (Naciones Unidas, 1969), Parte III, Sección 3: interpretación de los Tratados, arts. 31 a 33): en Zavalía, Víctor: «Recopilación ...», Op. Cit. págs. 770 a 772.

376 Conf. Pastor Ridruejo, Rafael. «Curso de Derecho Internacional Público» 2da ed., pág. 137; Ed. Técnos, Madrid, España, 1987.

377 Conf. Corte Interamericana de Derechos Humanos: «Otros tratados: objeto de la función consultiva de la Corte»; párr. 33, Op. Cit. pág. 17.

378 Corte Interamericana de Derechos Humanos: «El Hábeas Corpus bajo suspensión de garantías (Arts. 27.2, 25.1 y 7.6, Convención Americana sobre Derechos Humanos)»; párr. 14, Op. Cit. pág. 11.

379 Podestá Costa, Luis y Ruda, José María: «Manual de Derecho Internacional Público ...», Op. Cit. Tomo II. pág. 103.

380 Corte Interamericana de Derechos Humanos: «Caso Caballero Delgado y Santana». Sentencia del 8 de diciembre de 1995; párr. 67; en: Corte Interamericana de Derechos Humanos: "Informe Anual 1995"; Op. Cit. págs. 135 a 163.

381 Todos estos casos de la Corte Internacional de Justicia están citados por Mariño Menéndez, Fernando: «Derecho Internacional Público, Parte General», Op. Cit. pág. 288.

382 Corte Interamericana de Derechos Humanos: «Caso Paniagua Morales y Otros». Excepciones Preliminares, Sentencia del 25 de enero de 1996, párr. 29 en: Corte Interamericana de Derechos Humanos: "CDH - CP2/96", pág. 1. Ed. Secretaría de la Corte, San José de Costa Rica, 3 de febrero de 1996.

383 Corte Interamericana de Derechos Humanos: «Restricciones a la pena de muerte (arts. 4.2 y 4.4, Convención Americana sobre Derechos Humanos)»; párr. 48, Op. Cit. pág. 29; y «Propuesta de modificación a la constitución política de Costa Rica relacionada con la naturalización». párr. 21, Op Cit. pág. 16.

384 Conf. Nieto Navia, Rafael: «Introducción al sistema interamericano de protección a los derechos humanos»; pág. 109; Ed. Instituto Interamericano de Derechos Humanos, Temis, Bogotá, Colombia, 1993.

385 Corte Interamericana de Derechos Humanos: «Caso Cayara»; Excepciones Preliminares; párr. 37, Op. Cit. pág. 21. 
386 Conf. Corte Internacional de Justicia: «Reports of Judgementes, Opinios and Orders», The Hague, Netherlands, 1951.

387 Corte Interamericana de Derechos Humanos: «El efecto de las reservas sobre la entrada en vigencia de la Convención Americana de Derechos humanos (arts. 74 y 75)»; párr. 19, Op. Cit. pág. 36.

388 Convención de Viena sobre Derecho de los Tratados: (Naciones Unidas, 1969); art. 32: Medios de interpretación complementarios; en: Zavalía, Víctor: "Recopilación ...", Op. Cit. pág. 771.

389 Conf. Corte Interamericana de Derechos Humanos: «Otros tratados: objeto de la función consultiva de la Corte»; párr. 45, Op. Cit. pág. 24.

390 Corte Interamericana de Derechos Humanos: «Restricciones a la pena de muerte (arts. 4.2 y 4.4, Convención Americana sobre Derechos Humanos)»; párr. 49, Op. Cit. pág. 29.; «Propuesta de modificación a la constitución política de Costa Rica relacionada con la naturalización»; párr. 22, Op. Cit. pág. 17; y «La expresión Leyes en el artículo 30 de la Convención Americana sobre Derechos Humanos»; párr. 13, Op. Cit. pág. 8 .

391 Conf. art. 38 parágrafo 3 del Estatuto de la Corte Internacional de Justicia; en Zavalía, Víctor: «Recopilación ...»; Op. Cit. pág. 52.

392 Corte Permanente de Justicia Internacional: «Advisory Opinion», 1935, P.C.I.J., series A/B, N 65, pág. 56.

393 Corte Interamericana de Derechos Humanos: «La expresión Leyes en el artículo 30 de la Convención Americana sobre Derechos Humanos»; párr. 32, Op. Cit. pág. 17; «El Hábeas Corpus bajo suspensión de garantías (Arts. 27.2, 25.1 y 7.6, Convención Americana sobre Derechos Humanos)»; párr. 24, Op. Cit. pág. 16. Secretaría de la Corte, San José de Costa Rica, 1987; y «Ciertas atribuciones de la Comisión Interamericana de Derechos Humanos (artículos 41, 42, 46, 47, 50 y 51 de la Convención Americana sobre Derechos Humanos)»; párr. 31, Op. Cit. pág. 14.

394 Conf. Nieto Navia, Rafael: «Introducción al sistema interamericano de protección a los derechos humanos»; Op. Cit. pág. 29.

395 Corte Interamericana de Derechos Humanos: «La expresión Leyes en el artículo 30 de la Convención Americana sobre Derechos Humanos»; párr. 23, Op. Cit. pág. 12.

396 Ver infra, Capítulo VII, II.2.

397 Corte Interamericana de Derechos Humanos: «La expresión Leyes en el artículo 30 de la Convención Americana sobre Derechos Humanos»; párr. 17, Op. Cit. pág. 9.

398 Cançado Trindade, Antônio: «Democracia y derechos humanos: el régimen emergente de la promoción internacional de la democracia y del Estado de Derecho»; en: "La Corte y el Sistema Interamericanos ..."; Op. Cit. pág. 529.

399 Corte Interamericana de Derechos Humanos: «La expresión Leyes en el artículo 30 de la Convención Americana sobre Derechos Humanos»; párr. 17, Op. Cit. pág. 9.

400 Conf. Cançado Trindade, Antônio: «O esgotamento de recursos internos no Direito Internacional»; Op Cit. pág. 23.

401 Conf. Convención Americana sobre Derechos Humanos: art. 46; en: Organización de los Estados Americanos: «Documentos básicos ...»; págs. 38/39. 
402 Conf. Corte Interamericana de Derechos Humanos: «Caso Velásquez Rodríguez»; párr. 61, Op. Cit. pág. 27; y «Caso Godínez Cruz»; párr. 64, Op. Cit. pág. 27. El Tribunal ha insistido con esta afirmación en otras de sus decisiones; ver Corte Interamericana de Derechos Humanos: «Caso Fairén Garbi y Solís Corrales»; párr. 85, Op. Cit. pág. 40; y «Caso Gangaram Panday». Excepciones Preliminares; párr. 38, Op. Cit. págs. $12 / 13$.

403 Conf. Medina, Cecilia: «Derecho Internacional de los Derechos Humanos», manual de enseñanza; Op. Cit. pág. 21.

404 Conf. Corte Interamericana de Derechos Humanos: «Caso Velásquez Rodríguez»; Sentencia del 29 de julio de 1988, párr. 166, Op. Cit. pág. 68; y «Caso Godínez Cruz». Sentencia del 21 de julio de 1989; párr. 175, Op. Cit. pág. 72.

405 Conf. Gros Espiell. Héctor: «La Convención Americana y la Convención Europea de Derechos Humanos: análisis comparativo...»; Op. Cit. pág. 148.

406 Corte Interamericana de Derechos Humanos: «Caso Fairén Garbi y Solís Corrales»; párr. 110, Op. Cit. pág. 48.

407 Conf. Salvioli, Fabián: «El sistema interamericano de protección de los derechos humanos», en: Institut International des Droits de l'Homme: "XXVIème Session d'Enseignement: Recueil des Cours", 1995, Op. Cit. pág. 249.

408 Conf. Corte Interamericana de Derechos Humanos: «Caso Velásquez Rodríguez». Sentencia del 29 de julio de 1988; párr. 68, Op. Cit. págs. 29/30; «Caso Godínez Cruz». Sentencia del 21 de julio de 1989; párr. 71, Op. Cit. pág. 29; y «Caso Fairén Garbi y Solís Corrales»; Sentencia del 15 de marzo de 1989; párr. 93, Op. Cit. págs. 42/3.

409 Buergenthal, Thomas; Grossman, Claudio; y Nikken, Pedro: «Manual internacional de derechos humanos...», Op. Cit. pág. 101.

410 Corte Interamericana de Derechos Humanos: «Caso Gangaram Panday». Excepciones Preliminares; párr. 39, Op. Cit. pág. 13. En igual sentido, «Caso Castillo Páez». Sentencia del 30 de enero de 1996; párr. 40; en: Corte Interamericana de Derechos Humanos: "CDH - CP2/96", Op. Cit. págs. 1 y 2; y «Caso Loayza Tamayo». Excepciones Preliminares; Sentencia del 31 de enero de 1996; párr. 40; en: Corte Interamericana de Derechos Humanos: "CDH - CP2/96", Op. Cit pág. 2.

411 Pastor Ridruejo, Rafael: «Curso de Derecho Internacional Público ...» 2da ed., Op. Cit. pág. 170.

412 Conf. Corte Interamericana de Derechos Humanos: «Asunto Viviana Gallardo y Otras», decisión del 13 de noviembre de 1981, N G 101/81, Serie A, párr. 26; «Caso Castillo Páez». Sentencia del 30 de enero de 1996; párr. 40; en: Corte Interamericana de Derechos Humanos "CDH - CP2/96", Op. Cit. págs. 1 y 2; y «Caso Loayza Tamayo». Excepciones Preliminares; Sentencia del 31 de enero de 1996; párr 40; en: Corte Interamericana de Derechos Humanos "CDH - CP2/96", Op. Cit. pág. 2.

413 Corte Interamericana de Derechos Humanos: «Caso Loayza Tamayo». Excepciones Preliminares; voto razonado del juez A. Cançado Trindade, párr. 5; en: Corte Interamericana de Derechos Humanos "CDH - CP2/96", Op. Cit. pág. 2.

414 Corte Interamericana de Derechos Humanos: «Excepciones al agotamiento de los recursos internos (Art. 46.1, 46.2.a y 46.2.b Convención Americana sobre Derechos Humanos)». párr. 36, Op. Cit. pág. 15; también un razonamiento similar puede observarse en Corte Interamericana de Derechos Humanos: «Caso Caballero Delgado y Santana». Excepciones Preliminares; párr. 63, Op. Cit. pág. 17. 
415 Conf. Corte Interamericana de Derechos Humanos: «Caso Velásquez Rodríguez». Excepciones Preliminares; párr. 88, Op. Cit. pág. 38; «Caso Godínez Cruz». Excepciones Preliminares; párr. 90, Op. Cit. pág. 38; «Caso Fairén Garbi y Solís Corrales»; Excepciones Preliminares; párr. 87, Op. Cit. pág. 40; «Excepciones al agotamiento de los recursos internos (Art. 46.1, 46.2.a y 46.2.b Convención Americana sobre Derechos Humanos)»; párr. 41, Op. Cit. pág. 16; «Caso Neira Alegría y Otros». Excepciones Preliminares; párr. 30, Op. Cit. págs. 12 y 13; «Caso Gangaram Panday». Excepciones Preliminares; párr. 38, Op. Cit. pág. 13. «Caso Castillo Páez». Sentencia del 30 de enero de 1996; párr. 40; en: Corte Interamericana de Derechos Humanos: "CDH - CP2/96", Op. Cit. págs. 1 y 2; y «Caso Loayza Tamayo». Excepciones Preliminares; párr. 40; en: Corte Interamericana de Derechos Humanos: "CDH - CP2/96", Op. Cit. pág. 2.

416 Así lo ha hecho la Corte, de manera general. A partir de la incorporación al Tribunal del Juez A. Cançado Trindade, quien sostiene que siendo una excepción preliminar, debe tratarse en la etapa oportuna, es decir, al momento de resolverse el resto de Excepciones Preliminares.

417 Conf. Carrillo Salcedo, Juan A.: «Soberanía de los Estados y Derechos Humanos», Op. Cit. pág. 131.

418 Nos remitimos en lo respectivo al Capítulo III, donde hemos analizado los mecanismos convencionales de protección de los derechos humanos.

419 Conf. Estatuto de la Corte Internacional de Justicia: art. 36, párr. 2; en Zavalía, Víctor: «Recopilación ...», Op. Cit. pág. 51.

420 Conf. Convención Europea de Derechos Humanos: art. 46; en: Conseil de l'Europe: "Droits de l'Homme ..." Op. Cit. págs. 183/4.

421 Conf. Convención Americana sobre Derechos Humanos: art. 62; en Organización de los Estados Americanos: «Documentos básicos ...» Op. Cit. págs. 42/3.

422 Corte Interamericana de Derechos Humanos: «Caso Cayara»; Excepciones Preliminares. Op. Cit. págs. 25 a 42 .

423 Conf. Pinto, Mónica «La denuncia ante la Comisión Interamericana de Derechos Humanos» Op. Cit. pág. 152.

424 Corte Interamericana de Derechos Humanos: «Caso Cayara»; Excepciones Preliminares»; párr. 63, Op. Cit. pág. 29; y «Caso Caballero Delgado y Santana». Excepciones Preliminares; párr. 44, Op. Cit. pág. 19.

425 Conf. Corte Interamericana de Derechos Humanos: «Caso Velásquez Rodríguez». Excepciones Preliminares; párr. 33, Op. Cit. pág. 16; «Caso Godínez Cruz». Excepciones Preliminares; párr. 36, Op. Cit. pág. 17; «Caso Fairén Garbi y Solís Corrales»; Excepciones Preliminares; párr. 38, Op. Cit. pág. 19; y «Caso Paniagua Morales y Otros». Excepciones Preliminares; párr. 42; en Corte Interamericana de Derechos Humanos: CDH - CP2/96, Op. Cit. pág. 1.

426 Conf. Corte Interamericana de Derechos Humanos: «Caso Velásquez Rodríguez»; párr. 60, Op. Cit. págs. 26/27; «Caso Godínez Cruz»; párr. 63, Op. Cit. págs. 26/27; y «Caso Fairén Garbi y Solís Corrales»; párr. 84, Op. Cit. pág. 39.

427 Corte Interamericana de Derechos Humanos: «Ciertas atribuciones de la Comisión Interamericana de Derechos Humanos (artículos 41, 42, 46, 47, 50 y 51 de la Convención Americana sobre Derechos Humanos)»; párr. 41, Op. Cit. pág 17.

428 Corte Interamericana de Derechos Humanos: «Caso Cayara»; Excepciones Preliminares; párr. 42, Op. Cit. pág. 22 «Caso Caballero Delgado y Santana». Excepciones Preliminares; párr. 44, Op. Cit. pág. 19; 
«Caso Paniagua Morales y Otros». Excepciones Preliminares, párr. 38; en Corte Interamericana de Derechos Humanos CDH - CP2/96, Op. Cit. pág. 1; «Caso Castillo Páez». Sentencia del 30 de enero de 1996; párr. 34; en: Corte Interamericana de Derechos Humanos "CDH - CP2/96", Op. Cit. págs. 1 y 2; y «Caso Loayza Tamayo». Excepciones Preliminares; párr. 33; en: Corte Interamericana de Derechos Humanos: "CDH CP2/96", Op. Cit. pág. 2.

429 Corte Interamericana de Derechos Humanos: «Caso Caballero Delgado y Santana». Excepciones Preliminares; párr. 52, Op. Cit. pág. 24.

430 Conf. Carta de las Naciones Unidas: art. 2.2; en: Zavalía, Víctor: «Recopilación ...» Op. Cit. pág. 13.

431 Conf. Jiménez de Aréchaga, Eduardo: «Principios generales que rigen la conducta de los Estados»; en: "El Derecho Internacional Contemporáneo", Op. Cit. Cap. IV, pág. 107.

432 Asamblea General: Resolución 2625 (1970), Naciones Unidas, en: Zavalía, Víctor: "Recopilación ..." Op. Cit. págs. 95/6.

433 Conf. Corte Interamericana de Derechos Humanos: «Responsabilidad internacional por expedición y aplicación de leyes violatorias de la Convención Americana sobre Derechos Humanos (arts. 1 y 2 de la Convención Americana sobre Derechos Humanos)»; párr. 35. Op. Cit. Serie A N 14.

434 Convención de Viena sobre Derecho de los Tratados: (Naciones Unidas, 1969), Parte III, Sección 3: interpretación de los Tratados, art. 31; en Zavalía, Víctor: «Recopilación ...», pág. 770.

435 Corte Interamericana de Derechos Humanos: «Ciertas atribuciones de la Comisión Interamericana de Derechos Humanos (artículos 41, 42, 46, 47, 50 y 51 de la Convención Americana sobre Derechos Humanos)»; párr. 26, Op. Cit. págs. 12/13; y «Responsabilidad internacional por expedición y aplicación de leyes violatorias de la Convención Americana sobre Derechos Humanos (arts. 1 y 2 de la Convención Americana sobre Derechos Humanos)»; párr. 37; Op. Cit. Serie A N 14; también se puede observar una redacción similar en: Corte Interamericana de Derechos Humanos: «Caso Neira Alegría y otros». Sentencia del 19 de enero de 1995; párr. 49; en: Corte Interamericana de Derechos Humanos: "Informe Anual 1995"; Op. Cit. págs. 41 a 62.

436 Ver supra, II.3.- «Para el acceso a la vía internacional del Sistema Interamericano de Derechos Humanos, debe procederse al agotamiento de los recursos internos».

437 Corte Interamericana de Derechos Humanos: «Caso Neira Alegría y Otros». Excepciones Preliminares; párr. 35, Op. Cit. pág. 14.

438 Corte Interamericana de Derechos Humanos: «Caso Caballero Delgado y Santana». Excepciones Preliminares; párr. 45, Op. Cit. pág. 19.

439 Conf. Corte Interamericana de Derechos Humanos: «Caso Velásquez Rodríguez». Sentencia del 29 de julio de 1988; párr. 127, Op. Cit. pág. 50; «Caso Godínez Cruz». Sentencia del 21 de julio de 1989; párr. 133, Op. Cit. pág. 51; y «Caso Fairén Garbi y Solís Corrales»; Sentencia del 15 de marzo de 1989; párr. 130, Op. Cit. pág. 56.

440 Conf. Corte Interamericana de Derechos Humanos: «Caso Velásquez Rodríguez»; Sentencia del 29 de julio de 1988; párr. 128, Op. Cit. pág. 50. «Caso Godínez Cruz»; Sentencia del 21 de julio de 1989; párr. 133, Op. Cit. pág. 51. y «Caso Fairén Garbi y Solís Corrales»; Sentencia del 15 de marzo de 1989; párr. 130, Op. Cit. pág. 56.

441 En el Sistema Interamericano han existido diferentes conductas por parte de los Estados: la resolución de los casos hondureños y los casos peruanos tramitados hasta el presente, han sido particularmente difíciles por la actitud de los gobiernos. En otros órdenes, Suriname, Argentina y Venezuela 
han aceptado la responsabilidad de sus Estados en los casos Aloeboetoe, Garrido y Baigorria, y El Amparo, respectivamente. No puede identificarse un patrón común, aunque es evidente que, cuanto más democrático (en el sentido substancial) sea un gobierno, más probabilidades existen de cooperación con los órganos de protección de los derechos humanos que funcionan en el seno de la Organización de los Estados Americanos.

442 Conf. Corte Interamericana de Derechos Humanos: «Caso Velásquez Rodríguez»; Sentencia del 29 de julio de 1988; párr. 129 y 130; Op. Cit. pág. 50. y «Caso Godínez Cruz». Sentencia del 21 de julio de 1989; párrs. 136 y 137, Op. Cit. pág. 52.

443 Corte Interamericana de Derechos Humanos: «Caso Gangaram Panday». Sentencia del 21 de enero de 1994; párr. 49, en: Corte Interamericana de Derechos Humanos: "Informe Anual 1994"; Op. Cit. pág. 33.

444 Conf. Estatuto de la Corte Internacional de Justicia: art. 38.2; en: Zavalía, Víctor: "Recopilación ..." Op. Cit. pág. 52.

445 Conf. Corte Interamericana de Derechos Humanos: «Caso Velásquez Rodríguez»; Sentencia del 29 de julio de 1988; párr. 163, Op. Cit. pág. 67; y «Caso Godínez Cruz»; Sentencia del 21 de julio de 1989; párr. 172, Op. Cit. pág. 70.

446 Sobre el avance del Derecho Internacional en la materia véase el Capítulo II del presente, en el acápite llamado «la subjetividad jurídico internacional del individuo».

447 Conf. Corte Interamericana de Derechos Humanos: «Responsabilidad internacional por expedición y aplicación de leyes violatorias de la Convención Americana sobre Derechos Humanos (arts. 1 y 2 de la Convención Americana sobre Derechos Humanos)»; Op. Cit. párr. 56.

448 Conf. Salvioli, Fabián: «La responsabilidad internacional estatal e individual mirada desde la Corte Interamericana de Derechos Humanos (a propósito de la Opinión Consultiva N 14)», en Revista de Relaciones Internacionales, año 5, N 8, pág. 98; La Plata, Argentina, 1995.

449 Conf. Corte Interamericana de Derechos Humanos: «Caso Velásquez Rodríguez». Sentencia del 29 de julio de 1988; párr. 170, Op. Cit. pág. 70; y «Caso Godínez Cruz». Sentencia del 21 de julio de 1989; párr. 179, Op. Cit. pág. 73.

450 Conf. Corte Interamericana de Derechos Humanos: «Caso Velásquez Rodríguez». Sentencia del 29 de julio de 1988; párr. 184, Op. Cit. págs. 75/76; y «Caso Godínez Cruz». Sentencia del 21 de julio de 1989; párr. 194, Op. Cit. pág. 79.

451 Conf. Pastor Ridruejo, Rafael: «Curso de Derecho Internacional Público» Op. Cit. 4ta ed., pág. 567.

452 Conf. Casado Raigón, Rafael: «La responsabilidad internacional resultante de la comisión de un crimen internacional»; en: "Derecho y Opinión", Revista del Departamento de Disciplinas Histórico Jurídicas y Económico Sociales, N 0, pág. 103, Córdoba, España, 1992.

453 Corte Interamericana de Derechos Humanos: «Caso Velásquez Rodríguez»: Indemnización Compensatoria (Art. 63.1 Convención Americana sobre Derechos Humanos); párr. 25, Op. Cit. pág. 20; y «Caso Godínez Cruz»: Indemnización Compensatoria (Art. 63.1 Convención Americana sobre Derechos Humanos); párr. 23, Op. Cit. pág. 18.

454 Corte Interamericana de Derechos Humanos: «Caso Aloeboetoe y Otros», Reparaciones (Art. 63.1 Convención Americana sobre Derechos Humanos); párr. 43; Op. Cit. pág. 19.

455 Conf. Convención Americana sobre Derechos Humanos: art. 63.1; en: Organización de los Estados Americanos: «Documentos básicos ...» Op. Cit. pág. 52. 
456 Salvioli, Fabián: « Algunas reflexiones sobre la indemnización en las sentencias de la Corte Interamericana de Derechos Humanos», en: "Estudios Básicos De Derechos Humanos III", Op. Cit. pág. 157.

457 Corte Interamericana de Derechos Humanos: «Caso Velásquez Rodríguez»: Indemnización Compensatoria (Art. 63.1 Convención Americana sobre Derechos Humanos); párr. 31, Op. Cit. pág. 22 y «Caso Godínez Cruz»: Indemnización Compensatoria (Art. 63.1 Convención Americana sobre Derechos Humanos); párr. 29, Op. Cit. pág. 20.

458 Conf. Salvioli, Fabián: «El Sistema Interamericano de protección de los Derechos Humanos», en: Institut International des Droits De l'Homme: "XXVIème Session d'Enseignement: Recueil des Cours 1995"; Op. Cit. pág. 254.

459 Corte Interamericana de Derechos Humanos: «Caso Velásquez Rodríguez»: Indemnización Compensatoria (Art. 63.1 Convención Americana sobre Derechos Humanos); párr. 26, Op. Cit. pág. 21.

460 Corte Interamericana de Derechos Humanos: «Caso Aloeboetoe y Otros», Reparaciones (Art. 63.1 Convención Americana sobre Derechos Humanos); párr. 50, Op. Cit. pág. 21.

461 Corte Interamericana de Derechos Humanos: «Caso Velásquez Rodríguez»: Indemnización Compensatoria (Art. 63.1 Convención Americana sobre Derechos Humanos); párr. 27, Op. Cit. pág. 21; y «Caso Godínez Cruz»: Indemnización Compensatoria (Art. 63.1 Convención Americana sobre Derechos Humanos); párr. 24, Op. Cit. pág. 18.

462 Ver Capítulo IV, II.-1 «La Competencia Consultiva»; y Capítulo VIII, II.1.- «El ámbito de la función consultiva de la Corte Interamericana de Derechos Humanos es el más amplio posible, dentro de los límites establecidos por la Convención Americana sobre Derechos Humanos».

463 Ver Capítulo II, III.3. «El derecho de los tratados y los derechos humanos».

464 Ibídem.

465 Conf. Pastor Ridruejo, Rafael. «Curso de Derecho Internacional Público» 2da ed., Op. Cit. pág 195.

466 Conf. «Austria vs. Italy», Application N. 788/60; en: "European Yearbook of Human Rights", Vol. 4 , pág. 140, 1961.

467 Conf. Ventura, Manuel y Zovatto, Daniel: «La función consultiva de la Corte Interamericana de Derechos Humanos»; Op. Cit. pág. 83.

468 Corte Interamericana de Derechos Humanos: «El efecto de las reservas sobre la entrada en vigencia de la Convención Americana de Derechos humanos (arts. 74 y 75)»; párr. 29, Op. Cit. pág. 44. y «Restricciones a la pena de muerte (arts. 4.2 y 4.4, Convención Americana sobre Derechos Humanos)»; párr. 49, Op. Cit. pág. 30.

469 Buergenthal, Thomas; Grossman, Claudio; y Nikken, Pedro: «Manual internacional de derechos humanos», Op. Cit. págs. 172.

470 Corte Interamericana de Derechos Humanos: «El efecto de las reservas sobre la entrada en vigencia de la Convención Americana de Derechos humanos (arts. 74 y 75)»; párr. 33, Op. Cit. pág. 46.

471 Buergenthal, Thomas; Grossman, Claudio; y Nikken, Pedro: «Manual internacional de derechos humanos», Op. Cit. págs. 172.

472 Corte Interamericana de Derechos Humanos: «El efecto de las reservas sobre la entrada en vigencia de la Convención Americana de Derechos humanos (arts. 74 y 75)». Op. Cit. Parte resolutiva. 
473 Conf. Hitters, Juan C.: «Derecho Internacional de los Derechos Humanos», Op. Cit. Tomo I, pág. 188.

474 Convención Americana de Derechos Humanos: art. 29, en: Organización de los Estados Americanos: «Documentos básicos ...»; Op. Cit. págs. 34/35.

475 Corte Interamericana de Derechos Humanos: «La Colegiación Obligatoria de Periodistas (arts. 13 y 29 Convención Americana sobre Derechos Humanos)»; párr. 52, Op. Cit. pág. 31.

476 Corte Interamericana de Derechos Humanos: «Exigibilidad del derecho de rectificación o respuesta (Arts. 14.1, 1.1 y 2, Convención Americana sobre Derechos Humanos)»; párr. 24, Op. Cit. pág. 13.

477 Convención Americana sobre Derechos Humanos: art. 1.1; en: Organización de los Estados Americanos: «Documentos básicos ...»; Op. Cit. págs. 25/26.

478 Corte Interamericana de Derechos Humanos: «Exigibilidad del derecho de rectificación o respuesta (Arts. 14.1, 1.1 y 2, Convención Americana sobre Derechos Humanos)»; párr. 33, Op. Cit. págs. 17/18.

479 Corte Interamericana de Derechos Humanos: «La expresión Leyes en el artículo 30 de la Convención Americana sobre Derechos Humanos»; parr. 38; Op. Cit. pág. 19.

480 Convención Americana sobre Derechos Humanos: art. 27.2 in fine; en: Organización de los Estados Americanos: «Documentos básicos ...» Op. Cit. pág. 34.

481 Corte Interamericana de Derechos Humanos: «El Hábeas Corpus bajo suspensión de garantías (Arts. 27.2, 25.1 y 7.6, Convención Americana sobre Derechos Humanos)»; párr. 44, Op. Cit. pág. 24.

482 Corte Interamericana de Derechos Humanos: «Garantías judiciales en estado de emergencia (arts. 27.2, 25 y 8, Convención Americana sobre Derechos Humanos)»; párrs. 40 y 41, Op. Cit. págs. 20 y 21.

483 Corte Interamericana de Derechos Humanos: «Otros tratados», Op. Cit. Serie A N 1; e «Interpretación de la Declaración de los Derechos y Deberes del Hombre en el marco del artículo 64 de la Convención Americana sobre Derechos Humanos». Op. Cit. Serie A N 10.

484 Corte Interamericana de Derechos Humanos: «Compatibilidad de un proyecto de ley con el artículo 8.2.h de la Convención Americana sobre Derechos Humanos». Op Cit. Serie A N 12.

485 Corte Interamericana de Derechos Humanos: «El efecto de las reservas sobre la entrada en vigencia de la Convención Americana de Derechos humanos (arts. 74 y 75)»; párr. 29, Op. Cit. pág. 44.

486 Corte Interamericana de Derechos Humanos: «Excepciones al agotamiento de los recursos internos (Art. 46.1, 46.2.a y 46.2.b Convención Americana sobre Derechos Humanos)».Op. Cit. Serie A N 11.

487 Corte Interamericana de Derechos Humanos: «Restricciones a la pena de muerte (arts. 4.2 y 4.4, Convención Americana sobre Derechos Humanos)»; párr. 76, Op. Cit. pág. 44.

488 Corte Interamericana de Derechos Humanos: «Caso Velásquez Rodríguez»; párr. 135, Op. Cit. pág. 51; «Caso Godínez Cruz»; párr. 141, Op. Cit. pág. 53; «Caso Neira Alegría y otros»; Sentencia del 19 de enero de 1995; párr. 21; en: Corte Interamericana de Derechos Humanos: "Informe Anual 1995"; Op. Cit. págs. 41 a 62. y "Caso Gangaram Panday». Sentencia del 21 de enero de 1994; párr. 49, en: Corte Interamericana de Derechos Humanos: "Informe Anual 1994"; Op. Cit. pág. 33.

489 Ver el desarrollo del principio de seguridad jurídica en la jurisprudencia de la Corte Interamericana de Derechos Humanos, en los casos y resoluciones analizados supra en el Capítulo VI. 
490 Corte Interamericana de Derechos Humanos: «Garantías judiciales en estado de emergencia (arts. 27.2, 25 y 8, Convención Americana sobre Derechos Humanos)». Opinión Consultiva OC-9/87 del 6 de octubre de 1987. Serie A N 9. párr. 24, pág. 13; Secretaría de la Corte, San José de Costa Rica, 1987.

491 Conf. Cor te Interamericana de Derechos Humanos: «Caso Velásquez Rodríguez». Excepciones Preliminares; párr. 91, Op. Cit. pág. 40; «Caso Godínez Cruz». Excepciones Preliminares; párr. 93; Op. Cit. pág. 39; y «Caso Fairén Garbi y Solís Corrales»; párr. 90; Op. Cit. págs. 41/2.

492 Conf. Corte Interamericana de Derechos Humanos: «Garantías judiciales en estado de emergencia (arts. 27.2, 25 y 8, Convención Americana sobre Derechos Humanos)»; párr. 24, Op. Cit. pág. 14.

493 Conf. Corte Interamericana de Derechos Humanos: «Garantías judiciales en estado de emergencia (arts. 27.2, 25 y 8, Convención Americana sobre Derechos Humanos)»; párr. 26, Op. Cit. pág. 15.

494 Conf. O'Donnell, Daniel: «Protección internacional de los derechos humanos ...», Op. Cit. pág. 16.

495 Como hemos mencionado, adherimos a dicha postura, considerando que esa obligatoriedad deriva de su aplicación por algunos órganos de Naciones Unidas (en particular la Comisión de Derechos Humanos en el marco de los Procedimientos Extraconvencionales), y porque devino en una norma consuetudinaria, o bien porque algunos de sus contenidos forman parte de los llamados principios generales del derecho (Ver Capítulo II, acápite final: el derecho de los tratados y los derechos humanos). Por otro lado, es coherente con la característica de progresividad que posee todo el Derecho Internacional de los derechos humanos (analizada supra, en el Capítulo II).

496 Ver Comisión Interamericana de Derechos Humanos: arts. 19 y principalmente 20; Estatuto de la Comisión Interamericana; en: Organización de los Estados Americanos: «Documentos básicos ...»; Op. Cit. págs. $81 / 82$.

497 Comisión Interamericana de Derechos Humanos: «Informe 28/92» Argentina. OEA. Ser.L/ V / II.82, Washington, Estados Unidos, 1992.

498 La C.I.D.H. ha resuelto en 1987, que los Estados Unidos de América habían violado los derechos a la vida y a la igualdad (Arts. I y II) de la Declaración Americana de Derechos y Deberes del Hombre, al haber ejecutado por aplicación de la pena de muerte, a dos personas que habían cometido el delito con anterioridad a haber cumplido dieciocho años de edad, en los estados de Texas y Carolina del Sur. Ver Comisión Interamericana de Derechos Humanos: Caso 9647. CIDH Resolución 3/87. Informe Anual de la CIDH 1986/7, OEA, Washington, 1987.

499 Corte Interamericana de Derechos Humanos: «Interpretación de la Declaración de los Derechos y Deberes del Hombre en el marco del artículo 64 de la Convención Americana sobre Derechos Humanos»; párr. 37, Op. Cit. págs. 20/1.

500 Cançado Trindade, Antônio: «El sistema interamericano de protección de los derechos humanos (1948 - 1995): evolución, estado actual y perspectivas ...»; en: "Derecho Internacional y Derechos Humanos"; Op. Cit. pág. 49.

501 Corte Interamericana de Derechos Humanos: «Interpretación de la Declaración de los Derechos y Deberes del Hombre en el marco del artículo 64 de la Convención Americana sobre Derechos Humanos»; párr. 42, Op. Cit. pág. 23.

502 Conf. Medina, Cecilia: «El sistema interamericano de promoción y protección de los derechos humanos», en: "Derecho Internacional de los Derechos Humanos ...", Op. Cit. pág. 143. 
503 Corte Interamericana de Derechos Humanos: «Interpretación de la Declaración de los Derechos y Deberes del Hombre en el marco del artículo 64 de la Convención Americana sobre Derechos Humanos»; párr. 43, Op. Cit. pág. 24.

504 Ver supra Capítulo III; particularmente III.2.- «Los mecanismos extraconvencionales».

505 Ver Convención de los Derechos del Niño: art. 38.2; en Naciones Unidas: «Derechos Humanos, folleto informativo N 10, Los derechos del niño», pág. 26; Ed. Naciones Unidas, Ginebra, Suiza, 1990; dejamos a salvo, sin embargo, que la doctrina critica este artículo porque limita la protección de los adolescentes sólo hasta los quince años.

506 Conf. Salvioli, Fabián: «La mujer en el Derecho Internacional Público: un viaje de medio siglo desde San Francisco a Pekín»; en: "A un año de Beijing ..." Op. Cit. pág. 17.

507 Véase al respecto, Klainer, Rosa, López, Daniel y Salvioli, Fabián: «El Derecho a la Identidad». Curso Taller de Educación a Distancia para Docentes: Módulo 3. Ediciones del Movimiento Ecuménico por los Derechos Humanos; Buenos Aires, Argentina, 1993.

508 Conf. Gros Espiell, Héctor: «No discriminación y libre determinación como normas imperativas de Derecho Internacional, con especial referencia a los efectos de su denegación sobre la legitimidad de los Estados que violan o desconocen esas normas imperativas»; en: "Estudios sobre Derechos Humanos I", Op. Cit. pág. 227.

509 Citemos como ejemplos la Declaración Universal de Derechos Humanos (1948), art. 1; Pacto Internacional de Derechos Económicos, Sociales y Culturales (1966) art 2; Pacto Internacional de Derechos Civiles y Políticos (1966) art. 2; Carta Africana de Derechos Humanos y de los Pueblos (1981) arts. 2 y 3; Carta Arabe de Derechos Humanos (1994) art. 2; y Convenio Europeo para la Protección de los Derechos del Hombre y las Libertades Fundamentales (1950) art. 14.

510 La Declaración Americana de los Derechos y Deberes del Hombre (1948), contiene uno de los elementos de la no discriminación, el derecho a la igualdad ante la ley, en el art. II; en cambio, el Pacto de San José de Costa Rica, se refiere directamente al Principio (art. 1).

511 Convención Americana sobre Derechos Humanos: art.1.1; en: Organización de los Estados Americanos: «Documentos básicos ...»; págs. 25/26.

512 Ya nos hemos referido a ella en el Capítulo III. La Convención ha sido adoptada por el XXIV Período de Sesiones de la Asamblea General de la Organización de los Estados Americanos, y está en vigor desde el 5 de marzo de 1995.

513 Corte Interamericana de Derechos Humanos: «Propuesta de modificación a la constitución política de Costa Rica relacionada con la naturalización»; párr. 55, Op. Cit. pág. 31.

514 Corte Interamericana de Derechos Humanos: «Caso Aloeboetoe y Otros», Reparaciones (Art. 63.1 Convención Americana sobre Derechos Humanos); párrs. 58 y 62, págs. 24 y 26 respectivamente.

515 Corte Interamericana de Derechos Humanos: «Propuesta de modificación a la constitución política de Costa Rica relacionada con la naturalización»; párr. 56, Op. Cit. pág. 32.

516 Particularmente, esto se ha dado en una Opinión Consultiva: Corte Interamericana de Derechos Humanos: «El efecto de las reservas sobre la entrada en vigencia de la Convención Americana de Derechos humanos (arts. 74 y 75)», Op. Cit. Serie A N 2.

517 Corte Interamericana de Derechos Humanos: «Otros tratados»; párr. 52; Op. Cit. pág. 28. 
518 Corte Interamericana de Derechos Humanos: «Interpretación de la Declaración de los Derechos y Deberes del Hombre en el marco del artículo 64 de la Convención Americana sobre Derechos Humanos» Op. Cit. Pág. 26.

519 Nos referimos a la ya citada resolución tomada por el Tribunal. Corte Interamericana de Derechos Humanos: «Compatibilidad de un proyecto de ley con el artículo 8.2.h de la Convención Americana sobre Derechos Humanos» Opinión Consultiva OC-12/91 del 6 de diciembre de 1991. Serie A N 12.

520 Corte Interamericana de Derechos Humanos: «Propuesta de modificación a la constitución política de Costa Rica relacionada con la naturalización»; párrs. 14 y 27. Op. Cit. Págs. 13 y 18.

521 Corte Interamericana de Derechos Humanos: «Otros tratados: objeto de la función consultiva de la Corte»; párr. 39; Op. Cit. pág. 19; y «Propuesta de modificación a la constitución política de Costa Rica relacionada con la naturalización»; párr. 19, Op. Cit. pág. 15.

522 Corte Interamericana de Derechos Humanos: «Restricciones a la pena de muerte (arts. 4.2 y 4.4, Convención Americana sobre Derechos Humanos)»; párr. 43, Op. Cit. pág. 25. Y «Propuesta de modificación a la constitución política de Costa Rica relacionada con la naturalización». párr. 19, Op. Cit. pág. 15.

523 Corte Interamericana de Derechos Humanos: «Otros tratados: objeto de la función consultiva de la Corte»; párr. 14; Op. Cit. pág. 9.

524 Corte Interamericana de Derechos Humanos: «Otros tratados: objeto de la función consultiva de la Corte»; párr. 27; Op. Cit. pág. 15.

525 Corte Interamericana de Derechos Humanos: «Propuesta de modificación a la constitución política de Costa Rica relacionada con la naturalización»; párr. 25, Op. Cit. pág. 18.

526 Corte Interamericana de Derechos Humanos: «Otros tratados: objeto de la función consultiva de la Corte»; párr. 18; pág. 11; y «Restricciones a la pena de muerte (arts. 4.2 y 4.4, Convención Americana sobre Derechos Humanos)»; párr. 36, Op. Cit. pág. 21.

527 Corte Interamericana de Derechos Humanos: «Otros tratados: objeto de la función consultiva de la Corte»; párr. 25; Op. Cit. pág. 14; y «Responsabilidad internacional por expedición y aplicación de leyes violatorias de la Convención Americana sobre Derechos Humanos (arts. 1 y 2 de la Convención Americana sobre Derechos Humanos)»; párr. 23; En: Corte Interamericana de Derechos Humanos: "Informe Anual 1994"; Op. Cit. pág. 96.

528 Corte Interamericana de Derechos Humanos: «Otros tratados: objeto de la función consultiva de la Corte»; párr. 31; Op. Cit. pág. 16; y «La Colegiación Obligatoria de Periodistas (arts. 13 y 29 Convención Americana sobre Derechos Humanos)»; párr. 21, Op. Cit. pág. 12.

529 Conf. Travieso, Juan Antonio: «La Corte Interamericana de Derechos Humanos ...»; Op. Cit. pág. 19.

530 Convención Americana Sobre Derechos Humanos: art. 61.2; en: Organización de los Estados Americanos: «Documentos básicos ...»; Op. Cit. pág. 43.

531 La propia Corte ha tenido ocasión de expresarse respecto al agotamiento de los procedimientos previstos en los artículos 48 a 50 del Pacto de San José de Costa Rica, cuando un Estado había renunciado a la instancia ante la Comisión Interamericana y decidió someter el caso directamente a la Corte: en esa oportunidad, el tribunal dijo que «... El procedimiento ante la Comisión no ha sido concebido en interés exclusivo del Estado, sino que permite el ejercicio de importantes derechos individuales, muy especialmente a las víctimas ...», por lo cual decidió no admitir el caso. Conf. Corte Interamericana de Derechos Humanos: 
«Asunto Viviana Gallardo y Otras», decisión del 13 de noviembre de 1981, N G 101/81, Serie A; Op. Cit. párr. 25.

532 Conf Dunshee de Abranches, C. A.: «La Corte Interamericana de Derechos Humanos», en: "La Convención Americana sobre Derechos Humanos", Op. Cit. pág. 138.

533 Marquez Rodríguez, Edith: «Las relaciones entre la Comisión y la Corte Interamericana de Derechos Humanos»; en: "La Corte y el Sistema Interamericanos de Derechos Humanos ...", Op. Cit. pág. 307.

534 Conf. Méndez, Juan: «Criterios para enviar casos a la Corte, plazos para referir un caso a la Corte (artículos 50 y 51 de la $\mathrm{CADH}$ ) y solicitud de reconsideración y de interrupción del plazo»; pág. 17. Ponencia dictada por el Autor, presentada al Seminario de Expertos sobre «El Sistema Interamericano de Promoción y Protección de los Derechos Humanos», organizado por la Comisión Interamericana de Derechos Humanos de la Organización de los Estados Americanos, entre el 2 y el 4 de diciembre de 1996, en la ciudad de Washington, Estados Unidos.

535 Corte Interamericana de Derechos Humanos: «La Colegiación Obligatoria de Periodistas (arts. 13 y 29 Convención Americana sobre Derechos Humanos)»; párrs. 25 y 26. Nótese que en una opinión consultiva, la Corte Interamericana de Derechos Humanos fija criterios para el mejor funcionamiento de su jurisdicción contenciosa, además de considerar el Sistema Interamericano como un todo, al analizar, desde su punto de vista interpretativo, los pasos dados por un caso ante la Comisión Interamericana.

536 Conf. Méndez, Juan: «Criterios para enviar casos a la Corte ...» Op. Cit. págs. 20 a 23.

537 Pinto, Mónica: «Encuadramiento jurídico internacional de la desaparición forzada de personas», en: "La Desaparición, crimen contra la humanidad" págs. 195/204; Ed: APDH, Buenos Aires, Argentina, 1987.

538 Shirer, William L.: «The Rise and Fall of the Third Reich»; pág. 958, Ed. Simon and Schuster, U.S.A. 1960.

539 Conf. Corte Interamericana de Derechos Humanos: «Caso Velásquez Rodríguez»; párr. 150, Op. Cit. pág. 61; «Caso Godínez Cruz»; párr. 158, Op. Cit. págs. 64/65; «Caso Fairén Garbi y Solís Corrales»; párr. 147, Op. Cit. pág. 62; y «Caso Blake»: Excepciones Preliminares, párr. 35; en: Corte Interamericana de Derechos Humanos: "CDH - CP4/96", pág. 1. Ed. Secretaría de la Corte, San José de Costa Rica, 4 de julio de 1996.

540 Comisión de Derechos Humanos (Naciones Unidas): Resolución 20, 29 de febrero de 1980.

541 Naciones Unidas: «Desapariciones forzadas o involuntarias»; folleto informativo N 6, págs. 6/7, Ginebra, Suiza, 1993.

542 Asamblea General (Naciones Unidas): Resolución 47/33 «Declaración sobre la Protección de Todas las Personas contra las desapariciones forzadas», aprobada el 18 de diciembre de 1992.

543 Conf. Corte Interamericana de Derechos Humanos: «Caso Velásquez Rodríguez»; Sentencia del 29 de julio de 1988; párr. 153, Op. Cit. pág. 62.; y «Caso Godínez Cruz»; Sentencia del 21 de julio de 1989; párr. 161, Op. Cit. pág. 66.

544 Salvioli, Fabián: «La Conferencia de Viena. El debate sobre derechos humanos en las relaciones internacionales contemporáneas». En: Relaciones Internacionales, Op. Cit., pág. 17.

545 World Conference on Human Rights: «The Vienna Declaration and Programme of Action»: United Nations, New York, August 1993, Parte II B 5* 62. 
546 Conf. Corte Interamericana de Derechos Humanos: «Caso Velásquez Rodríguez». Sentencia del 29 de julio de 1988; párr. 158, Op. Cit. pág. 65; «Caso Godínez Cruz»; Sentencia del 21 de julio de 1989; párr. 166, pág. 69; y «Caso Fairén Garbi y Solís Corrales»; Sentencia del 15 de marzo de 1989; párr. 151, Op. Cit. pág. 62.

547 Conf. Nieto Navia, Rafael: «Introducción al sistema interamericano ...»; Op. Cit. pág. 154.

548 Conf. Corte Interamericana de Derechos Humanos: «Caso Velásquez Rodríguez»; Sentencia del 29 de julio de 1988; párr. 155, Op. Cit. pág. 63; «Caso Godínez Cruz»; Sentencia del 21 de julio de 1989; párr. 163, Op. Cit. pág. 66; y «Caso Fairén Garbi y Solís Corrales»; Sentencia del 15 de marzo de 1989; párr. 147, Op. Cit. pág. 62.

549 Conf. Amnistía Internacional: «Informe sobre la Tortura», pág. 10, Ed. Edai, Madrid, España, 1984.

550 Conf. Corte Interamericana de Derechos Humanos: «Caso Velásquez Rodríguez». Sentencia del 29 de julio de 1988; párr. 156, Op. Cit. pág. 64; «Caso Godínez Cruz»; Sentencia del 21 de julio de 1989; párr. 164, Op. Cit. págs. 67/8; y «Caso Fairén Garbi y Solís Corrales»; Sentencia del 15 de marzo de 1989; párr. 149, Op. Cit. pág. 62.

551 Conf. Corte Interamericana de Derechos Humanos: «Caso Velásquez Rodríguez». Sentencia del 29 de julio de 1988; párr. 156, Op. Cit. pág. 65; y «Caso Godínez Cruz»; Sentencia del 21 de julio de 1989; párr. 164, Op. Cit. pág. 68.

552 Conf. Corte Interamericana de Derechos Humanos: «Caso Velásquez Rodríguez». Sentencia del 29 de julio de 1988; párr. 157, Op. Cit. pág. 65; «Caso Godínez Cruz»; Sentencia del 21 de julio de 1989; párr. 165, Op. Cit. pág. 68 y «Caso Fairén Garbi y Solís Corrales»; Sentencia del 15 de marzo de 1989; párr. 150, Op. Cit. pág. 62.

553 Convención Interamericana sobre Desaparición Forzada de Personas Artículo II; en: Organización de los Estados Americanos: «Documentos básicos ....»; pág. 146.

554 Convención Interamericana sobre Desaparición Forzada de Personas Artículo XII; en Ibídem, pág. 149.

555 Convención Interamericana sobre Desaparición Forzada de Personas Artículo VIII; en Ibídem, pág. 148.

556 Convención Interamericana sobre Desaparición Forzada de Personas Preámbulo, en Ibídem, págs. $145 / 46$.

557 Sobre el derecho a la educación en general puede verse Klainer, Rosa; López, Daniel y Salvioli, Fabián: «El Derecho a la educación». Curso Taller de Educación a Distancia para Docentes: Módulo 2; Ediciones del Movimiento Ecuménico por los Derechos Humanos, Buenos Aires, Argentina, 1992.

558 Declaración Universal de Derechos Humanos: art. 26; en: Naciones Unidas: "Derechos Humanos, Recopilación ...", Op. Cít. pág. 6.

559 Declaración de los Derechos del Niño: Principio 7, en: Ibídem, Op. Cit. pág. 368.

560 Pacto Internacional de Derechos Económicos, Sociales y Culturales: art. 13; en Ibídem, Op. Cit. pág. 14.

561 Convención de los Derechos del Niño: arts. 28 a 30; en Naciones Unidas: «Derechos Humanos, Folleto Informativo N 10, Derechos del Niño», Op. Cit. págs. 23 y 24. 
562 Corte Interamericana de Derechos Humanos: «Caso Velásquez Rodríguez», Indemnización Compensatoria, sentencia de 21 de julio de 1989, párr. 48, Op. Cit. pág. 27. y «Caso Godínez Cruz», Indemnización Compensatoria, sentencia de 21 de julio de 1989, párrafos 46 Op. Cit. pág. 24. El mismo razonamiento, aunque con otras palabras, es recogido por la jurisprudencia en: Corte Interamericana de Derechos Humanos: «Caso Aloeboetoe y otros», Reparaciones (Art. 63.1 Convención Americana sobre Derechos Humanos); párr. 85, Op. Cit. pág. 36.

563 Corte Interamericana de Derechos Humanos: «Caso Velásquez Rodríguez», Indemnización Compensatoria; párr. 58, Op. Cit. pág. 30; existe una resolución similar en: «Caso Godínez Cruz», Indemnización Compensatoria, párr. 53; Op. Cit. pág. 26.

564 Corte Interamericana de Derechos Humanos: «Caso Aloeboetoe y Otros», Reparaciones (Art. 63.1 Convención Americana sobre Derechos Humanos); párrs. 99 a 108, Op. Cit. págs. 43 a 45.

565 Corte Interamericana de Derechos Humanos: «Caso Aloeboetoe y Otros», Reparaciones (Art. 63.1 Convención Americana sobre Derechos Humanos); párr. 96, Op. Cit. págs. 38 y 39.

566 Corte Interamericana de Derechos Humanos: «Caso Aloeboetoe y Otros», Reparaciones (Art. 63.1 Convención Americana sobre Derechos Humanos); párr. 116, Op. Cit. págs. 47/48. 